VILNIAUS GEDIMINO TECHNIKOS UNIVERSITETAS

Agnè KAIRYTE்

\title{
BIOPOLIURETANO PUTŲ, MODIFIKUOTŲ POPIERIAUS GAMYBOS ATLIEKOMIS, TYRIMAI
}

DAKTARO DISERTACIJA

TECHNOLOGIJOS MOKSLAI, MEDŽIAGŲ INŽINERIJA (08T) 
Disertacija rengta 2013-2017 metais Vilniaus Gedimino technikos universitete.

\section{Vadovas}

dr. Sigitas VÉJELIS (Vilniaus Gedimino technikos universitetas, medžiagų inžinerija - 08T).

Vilniaus Gedimino technikos universiteto Medžiagų inžinerijos mokslo krypties disertacijos gynimo taryba:

\section{Pirmininkas}

dr. Valentin ANTONOVIČ (Vilniaus Gedimino technikos universitetas, medžiagų inžinerija - 08T).

\section{Nariai:}

dr. Viktor KIZINIEVIČ (Vilniaus Gedimino technikos universitetas, medžiagų inžinerija - 08T),

dr. Jurgita MALAIŠKIENÉ (Vilniaus Gedimino technikos universitetas, medžiagų inžinerija - 08T),

dr. Inga MATIJOŠYTĖ (Vilniaus universitetas, biochemija - 04P),

dr. Janis RIŽIKOVS (Valstybinis Latvijos medienos chemijos institutas, chemijos inžinerija - 05T).

Disertacija bus ginama viešame Medžiagų inžinerijos mokslo krypties disertacijos gynimo tarybos posėdyje $2017 \mathrm{~m}$. lapkričio 3 d. 13 val. Vilniaus Gedimino technikos universiteto senato posėdžių salèje.

Adresas: Saulètekio al. 11, LT-10223 Vilnius, Lietuva.

Tel.: (8 5) 274 4956; faksas (8 5) 270 0112; el. paštas doktor@vgtu.lt

Pranešimai apie numatomą ginti disertaciją išsiųsti $2017 \mathrm{~m}$. spalio $2 \mathrm{~d}$.

Disertaciją galima peržiūrèti VGTU talpykloje http://dspace.vgtu.lt ir Vilniaus Gedimino technikos universiteto bibliotekoje (Saulètekio al. 14, LT-10223 Vilnius, Lietuva).

VGTU leidyklos TECHNIKA 2017-060-M mokslo literatūros knyga http://leidykla.vgtu.lt

ISBN 978-609-476-067-9

(C) VGTU leidykla TECHNIKA, 2017

(C) Agnè Kairytè, 2017

agne.kairyte@vgtu.lt 
VILNIUS GEDIMINAS TECHNICAL UNIVERSITY

Agnè KAIRYTE்

RESEARCH OF BIOPOLYURETHANE FOAM MODIFIED WITH PAPER PRODUCTION WASTE

DOCTORAL DISSERTATION

TECHNOLOGICAL SCIENCES,

MATERIALS ENGINEERING (08T)

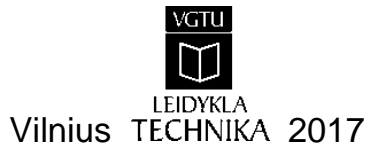


Doctoral dissertation was prepared at Vilnius Gediminas Technical University in 2013-2017.

\section{Supervisor}

Dr Sigitas VĖJELIS (Vilnius Gediminas Technical University, Materials Engineering - 08T).

The Dissertation Defence Council of Scientific Field of Materials Engineering of Vilnius Gediminas Technical University:

\section{Chairman}

Dr Valentin ANTONOVIČ (Vilnius Gediminas Technical University, Materials Engineering - 08T).

\section{Members:}

Dr Viktor KIZINIEVIČ (Vilnius Gediminas Technical University, Materials Engineering - 08T),

Dr Jurgita MALAIŠKIENE (Vilnius Gediminas Technical University, Materials Engineering - 08T),

Dr Inga MATIJOŠYTÉ (Vilnius University, Biochemistry - 04P),

Dr Janis RIŽIKOVS (Latvian State Institute of Wood Chemistry, Chemical Engineering - 05T).

The dissertation will be defended at the public meeting of the Dissertation Defence Council of Materials Engineering in the Senate Hall of Vilnius Gediminas Technical University at 1 p. m. on 3 November 2017.

Address: Saulètekio al. 11, LT-10223 Vilnius, Lithuania. Tel.: +370 5274 4956; fax +370 5270 0112; e-mail: doktor@vgtu.lt

A notification on the intend defending of the dissertation was sent on 2 October 2017.

A copy of the doctoral dissertation is available for review at VGTU repository http://dspace.vgtu.lt and at the Library of Vilnius Gediminas Technical University (Saulètekio al. 14, LT-10223 Vilnius, Lithuania). 


\section{Reziumè}

Disertacijoje nagrinejjamos modifikuotos standžiosios poliuretano putos iš biopoliolių, kurių struktūros ir savybių keitimui naudojamos termiškai ir chemiškai apdorotos popieriaus gamybos atliekų dumblo dalelès. Detaliai išanalizavus šios atliekos savybes bei poveiki gaminiams, galima sukurti putas, pasižyminčias norminiais dokumentais apibrèžtomis bei termoizoliacinėms medžiagoms būdingomis savybėmis. Disertacijos tikslas - sukurti ir ištirti poliuretano putas, susintetintas iš rapsų aliejaus poliolių ir modifikuotas popieriaus gamybos atliekų dumblo dalelèmis.

Disertaciją sudaro įvadas, trys skyriai, bendrosios išvados, literatūros ir autorès publikacijų disertacijos tema sąrašai. İvadiniame skyriuje aptariama tiriamoji problema, darbo aktualumas, aprašomas tyrimų objektas, formuluojamas darbo tikslas bei uždaviniai šiam tikslui pasiekti, aprašoma tyrimų metodika, darbo mokslinis naujumas, darbo rezultatu praktinè reikšmé bei ginamieji teiginiai. Ivado pabaigoje pristatomos disertacijos tema autorès paskelbtos publikacijos ir pranešimai konferencijose bei disertacijos struktūra.

Pirmajame skyriuje aptartas atsinaujinančių išteklių, kaip dar vienos priemonès, darniojo vystymosi tikslų igyvendinimui naudojimas poliuretano putų gamyboje. Taip pat nagrinejjama pagrindinių poliuretano putų žaliavų - poliolių, izocianato, vandens, katalizatorių, paviršių aktyvinančių medžiagų poveikis galutinių gaminių struktūrai ir savybėms. Apžvelgiamos galimybės poliuretano putų savybių modifikavimui naudoti daugiafunkcius grandinès plètiklius. Taip pat analizuojamas popieriaus gamybos atliekų dumblas, susidarantis atliekinio vandens valymo įrenginiuose, bei jo panaudojimo galimybès statybinių medžiagų pramonejje, kitų užpildų poveikis polimerinių medžiagų savybèms, titanatų, silanų bei cirkonatų panaudojimas.

Antrajame skyriuje aprašomos darbe naudotos žaliavos ir jų savybès, taikyti tyrimų metodai bei poliuretano putų, propilenglikoliu ir popieriaus gamybos atliekų dumblo dalelëmis modifikuotų poliuretano putų sudètys bei technologinè bandiniu gamybos schema.

Trečiajame skyriuje tiriamas vandens kiekio poveikis poliuretano putų tankiui, pradinei susitraukčiai bei matmenų stabilumui padidintos temperatūros ir drégmès sąlygomis. Papildomai tiriamas propilenglikolio iš rapsų glicerino ir rapsų glicerino, kaip grandinès plètiklio, poveikis gaminių fizikinèms ir mechaninèms savybèms. Taip pat pateikiami propilenglikoliu ir popieriaus gamybos atliekų dumblo dalelèmis modifikuotų poliolio mišinių klampos bei poliuretano putų eksploatacinių savybių ir struktūros tyrimų rezultatai.

Disertacijos medžiaga paskelbta 5 moksliniuose straipsniuose, o tyrimų rezultatai pristatyti 6 nacionalinèse ir tarptautinèse mokslinèse konferencijose. 


\section{Abstract}

The thesis investigates rigid polyurethane foam from biopolyols for which structure and properties modification, paper thermally and chemically treated paper production waste sludge particles are used. After detailed analysis of properties and impact on products of these waste, polyurethane foams with properties, which are characteristic to thermal insulating materials and defined in normative referecnces, may be obtained. The aim of the dissertation - to develop and test dimensionally stable polyurethane foam synthesyzed from rapeseed oil-based polyols and modified with paper production waste sludge particles.

The thesis consists of introduction, three chapters, general conclusions, references and the list of author's publications. The introduction reveals the problem under investigation, topicality of the work, the research object, aims and tasks, methodology, novelty of the work, significance of the obtained results as well as defended statements. In the end of introduction, publications of the author, presentations at conferences and dissertation structure are presented.

Chapter 1 presents the usage of renewable resources in the production of polyurethane foam as one of the measures for the implementation of sustainable development aims. It is as well analysed the impact of raw materials-polyols, isocyanates, water, catalysts, surfactants and chain extenders on the structure and properties of the final products. The possibility of multifunctional chain extenders to be used in polyurethane foam producted is considered. Analysis of feasibility of paper production waste sludge obtained from waste water treatment equipment as well as non modified and titanates, silanes and zirconate modified fillers to be used in building materials industry is conducted.

Chapter 2 describes raw materials used in the work, their properties, conducted research methods as well as compositions and technological production scheme of polyurethane foam, propylene glycol modified polyurethane foam and propylene glycol and paper production waste sludge particles modified polyurethane foam specimens.

Chapter 3 investigates water amount impact on the density, initial shrinkage and dimensional stability at increased temperature and relative humidity of polyurethane foam. It presents the impact of propylene glycol from rapeseed glycerine and rapeseed glycerine as chain extenders on physical and mechanical properties of the products. It as well demonstrates the results of dynamic viscosity of propylene glycol and paper production waste sludge particles modified polyol mixtures, performance and structure of polyurethane foam composites.

5 articles focusing on the subject of the discussed thesis are published and results of the research are presented in 6 scientific conferences at national and international level. 


\section{Žymèjimai ir sąvokos}

\section{Simboliai}

$b_{1}$ - ilgis, plotis arba storis atitinkamai po 0,5 val po gamybos, $\mathrm{mm}$;

$b_{2}$ - ilgis, plotis arba storis po 1 dienos po gamybos, mm;

$E_{\mathrm{H}_{2} \mathrm{O}}$ - vandens ekvivalentinè masè, $\mathrm{g} / \mathrm{mol}$;

$E_{M D I}$ - izocianato ekvivalentinè masè, $\mathrm{g} / \mathrm{mol}$;

$E_{P}$ - poliolio ekvivalentinè masè, g/mol;

$E_{R G L}-$ glicerino ekvivalentinè masè, $\mathrm{g} / \mathrm{mol}$;

$E_{R P G}$ - propilenglikolio ekvivalentinè masè, g/mol;

$F_{M}$ - poliolių mišinio funkcinių grupių skaičius (toliau tekste b. d.);

$F_{P}$ - poliolio funkcinių grupių skaičius, b. d.;

$F_{R G L}-$ glicerino funkcinių grupių skaičius, b. d.;

$F_{R P G}$ - propilenglikolio funkcinių grupių skaičius, b. d.;

$I_{M D I}$ - numatytasis izocianato indeksas, bedimensis dydis;

$Y_{\text {progn }}$ - minimali arba maksimali prognozuojamoji intervalinè verte;

$Y_{X_{i}}-$ taškinè verté;

$k_{\mathrm{H}_{2} \mathrm{O}}$ - vandens moliai, mol; 
$k_{P}$ - poliolio moliai, mol;

$k_{R G L}$ - glicerino moliai, mol;

$k_{R P G}-$ propilenglikolio moliai, mol;

$K S_{\text {Uretano }}$ - apskaičiuotasis uretano grupių kietujų segmentų kiekis, \%;

$K S_{\text {Ureja }}$ - apskaičiuotasis urejja grupių kietujų segmentų kiekis, \%;

$m_{\mathrm{H}_{2} \mathrm{O}}$ - vandens kiekis, dpm;

$m_{M D I}-$ izocianato kiekis, dpm;

$m_{P}$ - poliolio kiekis, dalimis pagal masę (toliau tekste dpm);

$m_{P G A D}-$ popieriaus gamybos atliekų dumblo dalelių kiekis, masès $\%$;

$m_{R G L}-$ glicerino kiekis, dpm;

$m_{R P G}$ - propilenglikolio kiekis, dpm;

$M_{\mathrm{CO}_{2}}-\mathrm{CO}_{2}$ dujų molekulinè masè, $\mathrm{g} / \mathrm{mol}$;

$M_{M}$ - poliolių mišinio molekulinè masè, $\mathrm{g} / \mathrm{mol}$;

$M_{M D I}$ - izocianato molekulinè masè, $\mathrm{g} / \mathrm{mol}$;

$M_{P}$ - poliolio molekulinè masè, $\mathrm{g} / \mathrm{mol}$;

$M_{R P G}$ - propilenglikolio molekulinè masè, $\mathrm{g} / \mathrm{mol}$;

$M_{R G L}-$ glicerino molekulinè masè, $\mathrm{g} / \mathrm{mol}$;

$M S_{P}$ - apskaičiuotasis poliolio minkštujų segmentų kiekis, \%;

$M S(x / y / z)$ - matmenų stabilumas ilgio (x), pločio (y) ir storio (z) kryptimis, \%

$n$-imties dydis, b. d.;

$n_{O H}$ - poliolio hidroksilų skaičius, $\mathrm{mg} \mathrm{KOH} / \mathrm{g}$;

$n_{O H(M)}$ - poliolių mišinio hidroksilų skaičius, $\mathrm{mg} \mathrm{KOH/g}$;

$S_{r}$ - vidutinis kvadratinis nuokrypis;

$S_{\bar{\lambda}_{R P G / P G A D / t}}-$ šilumos laidumo koeficiento priklausomybès vidutinis kvadratinis nuokrypis, $\mathrm{W} /(\mathrm{m} \cdot \mathrm{K})$;

$S_{\bar{\rho}_{H_{2} \mathrm{O}}}$ - tariamojo tankio priklausomybès nuo vandens kiekio vidutinis kvadratinis nuokrypis, $\mathrm{kg} / \mathrm{m}^{3}$;

$S_{\bar{\rho}_{R P G / P G A D}}$ - tariamojo tankio priklausomybès nuo propilenglikolio ir popieriaus gamybos atliekų dumblo dalelių kiekių vidutinis kvadratinis nuokrypis, $\mathrm{kg} / \mathrm{m}^{3}$;

$S_{\bar{\sigma}_{R G L}}-$ glicerinu modifikuotų sistemų gniuždymo stiprio vidutinis kvadratinis nuokrypis, $\mathrm{kPa}$; 
$S_{\bar{\sigma}_{P P G}}$ - propilenglikoliu modifikuotų sistemų gniuždymo stiprio vidutinis kvadratinis nuokrypis, $\mathrm{kPa}$;

$S_{\bar{W}_{28}}$-ilgalaikès vandens sugerties visiškai jame panardinus priklausomybès vidutinis kvadratinis nuokrypis, \%;

$t$ - išlaikymo laikas, dienos;

$t_{\alpha}-$ Stjudento kriterijus, b. d.;

$T_{m_{1}}-1$-ojo terminio efekto temperatūroa, ${ }^{\circ} \mathrm{C}$;

$T_{m_{2}}-2$-ojo terminio efekto temperatūra, ${ }^{\circ} \mathrm{C}$;

$T_{m_{3}}-3$-ojo terminio efekto temperatūra, ${ }^{\circ} \mathrm{C}$;

$T_{p r}$ - terminio irimo pradžios temperatūra, ${ }^{\circ} \mathrm{C}$;

$W_{P}$ - poliolio masé, g;

$W_{\text {Viso }}$ - visų medžiagų masè, g;

$W_{28}$ - taškiné ilgalaikès vandens sugerties visiškai jame panardinus verté, \%;

$\bar{W}_{28}$ - vidutinè ilgalaikès vandens sugerties visiškai jame panardinus verte, $\%$;

$\delta$ - galima paklaidos verte;

$\eta^{2}$ - koreliacijos santykio kvadratas, b. d.;

$\eta_{\bar{W}_{28}}^{2}-$ ilgalaikès vandens sugerties visiškai jame panardinus priklausomybès koreliacijos santykio kvadratas, b. d.;

$\eta_{\bar{\lambda}_{R P G / P G A / /}}^{2}-$ šilumos laidumo koeficiento priklausomybès nuo propilenglikolio ir popieriaus gamybos atliekų dumblo dalelių kiekių bei laiko koreliacijos santykio kvadratas, b. d.;

$\eta_{\bar{\rho}_{H_{2} O} \mathrm{O}}^{2}-$ tariamojo tankio priklausomybès nuo vandens kiekio koreliacijos santykio

kvadratas, b. d.;

$\eta_{\bar{\rho}_{R P G / P G A}}^{2}-$ tariamojo tankio priklausomybès nuo propilenglikolio ir popieriaus gamybos atliekų dublo dalelių kiekių koreliacijos santykio kvadratas, b. d.;

$\eta_{\bar{\sigma}_{R C L}}^{2}-$ gniuždymo stiprio priklausomybès nuo glicerino kiekio koreliacijos santykio kvadratas, b. d.;

$\eta_{\bar{\sigma}_{R P G}}^{2}-$ gniuždymo stiprio priklausomybės nuo propilenglikolio kiekio koreliacijos santykio kvadratas, b. d.; 
$\bar{\lambda}_{R P G / P G A D / t}-$ vidutine propilenglikoliu ir popieriaus gamybos atliekų dumblo dalelëmis modifikuotų sistemų šilumos laidumo koeficiento vertè, $\mathrm{W} /(\mathrm{m} \cdot \mathrm{K})$;

$\mu$ - vandens garų varžos faktorius, b. d.;

$\rho_{\text {progn }}-$ minimali arba maksimali prognozuojamoji tariamojo tankio verte, $\mathrm{kg} / \mathrm{m}^{3}$; $\rho_{R P G / P G A D}-$ taškinè propilenglikoliu ir popieriaus gamybos atliekų dumblo dalelèmis modifikuotų sistemų tariamojo tankio vertè, $\mathrm{kg} / \mathrm{m}^{3}$;

$\bar{\rho}_{\mathrm{H}_{2} \mathrm{O}}$ - vidutiné vandeniu išpūstų sistemų tariamojo tankio verte, $\mathrm{kg} / \mathrm{m}^{3}$;

$\bar{\rho}_{R G L}$ - vidutiné glicerinu modifikuotų sistemų tariamojo tankio verte, $\mathrm{kg} / \mathrm{m}^{3}$;

$\bar{\rho}_{R P G}$ - vidutinè propilenglikoliu modifikuotų sistemų tariamojo tankio verté, $\mathrm{kg} / \mathrm{m}^{3}$;

$\sigma_{\text {RGLprogn }}-$ prognozuojamosios gniuždymo stiprio vertès glicerinu modifikuotose sistemose, $\mathrm{kPa}$;

$\sigma_{R P G, p r o g n}-$ prognozuojamosios gniuždymo stiprio vertès propilenglikoliu modifikuotose sistemose, $\mathrm{kPa}$;

$\sigma_{R G L}$ - taškinè glicerinu modifikuotų sistemų gniuždymo stiprio vertè, $\mathrm{kPa}$;

$\sigma_{R P G}$ - taškinè propilenglikoliu modifikuotų sistemų gniuždymo stiprio vertè, $\mathrm{kPa}$;

$\bar{\sigma}_{R G L}$ - vidutine glicerinu modifikuotų sistemų gniuždymo stiprio vertè, $\mathrm{kPa}$;

$\bar{\sigma}_{R P G}$ - vidutiné propilenglikoliu modifikuotų sistemų gniuždymo stiprio vertè, $\mathrm{kPa}$;

$\bar{\sigma}_{T R P G}-$ vidutiné propilenglikoliu modifikuotų sistemų tempimo stiprio verté, $\mathrm{kPa}$; $\Delta \varepsilon$ - pradinè susitrauktis, $\%$.

\section{Santrumpos}

b. d. - bedimensis dydis;

CFC - anglies fluoridas (angl. Chlorofluorocarbon);

$\mathrm{COY}_{\text {vid. }}$ - vidutinis anglies monoksido kiekis (angl. average Carbon Monoxide

Yield);

$\mathrm{CO}_{2} \mathrm{Y}_{\text {vid. }}$ - vidutinis anglies dioksido kiekis (angl. average Carbon Dioxide Yield);

DTA - diferencinè terminè analizé;

GWP - globalinio atšilimo potencialas (angl. Global Warming Potential);

HCFC - chlorintas ir fluorintas angliavandenilis (angl. Hydrochlorofluorocarbon);

HFC - fluorintas angliavandenilis (angl. Hydrofluorocarbon);

$\mathrm{HFO}$ - fluorintas angliavandenilis olefinų pagrindu (angl. Hydrofluoroolefin);

b. d. - bedimensis dydis; 
HRR - šilumos išsiskyrimo greitis (angl. Heat Release Rate);

MDI - metileno difenilo diizocianatas;

$\mathrm{NCO}$ - funkcinès izocianatų grupès;

ODP - ozono sluoksnio ardymo potencialas (angl. Ozone Depletion Potential);

$\mathrm{OH}$ - funkcinès poliolių grupès;

dpm - dalys pagal masę;

pHRR - maksimalus taškinis šilumos išsiskyrimo greitis (angl. peak Heat Re-

lease Rate);

$\mathrm{pHRR}_{\text {vid. }}$ - vidutinis maksimalus šilumos išsiskyrimo greitis (angl. average peak

Heat Release Rate);

pMDI - polimerinis metileno difenilo diizocianatas;

PAM - paviršių aktyvinanti medžiaga;

PGAD - popieriaus gamybos atliekų dumblas;

RGL - rapsų glicerinas;

$\mathrm{RPG}$ - propilenglikolis iš rapsų glicerino;

TDI - tolueno diizocianatas;

TGA - termogravimetrinè analizè;

$\mathrm{THR}_{\text {vid. }}$ - vidutinis visuminis šilumos išsiskyrimas (angl. average Total Heat Release);

$\mathrm{TSR}_{\text {vid. }}$ - vidutinis visuminis dūmų išsiskyrimas (angl. average Total Smoke Release).

\section{Sąvokos}

Alofanatas - cheminė grupé, atsirandanti poliuretanuose ir besiformuojanti tarp uretano grupès ir perteklinio izocianato kiekio. Šios grupès medžiagoje formuoja skersinius ryšius.

Grandinès plètikliai - difunkcinès ar daugiafunkcès medžiagos, formuojančios, atitinkamai, tiesinę struktūrą ar skersinius ryšius.

Užuomazgas sudarantys centrai - kietosios dalelès, skatinančios burbuliukų formavimąsi skystyje.

Uždaros akutės - tai akutės, kurios yra visiškai uždarytos plona plastiko sienele ar membrana ir yra užpildytos dujodariu. 



\section{Turinys}

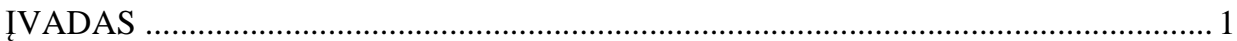

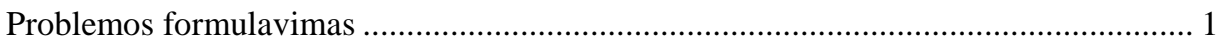

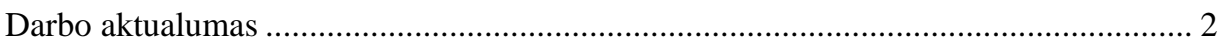

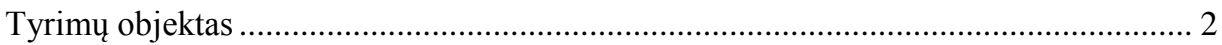

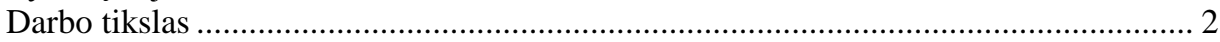

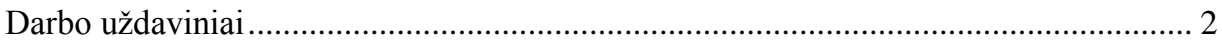

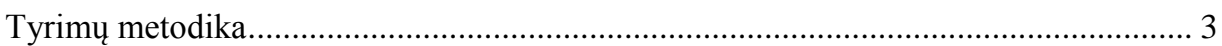

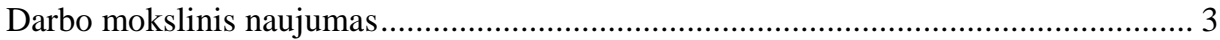

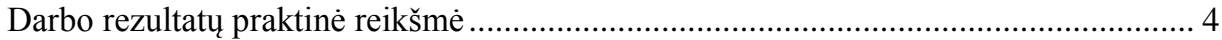

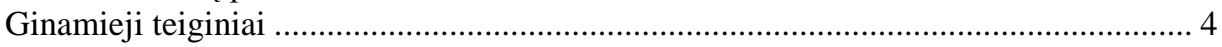

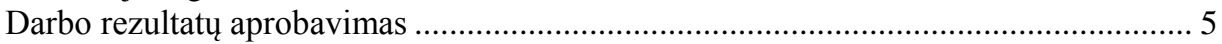

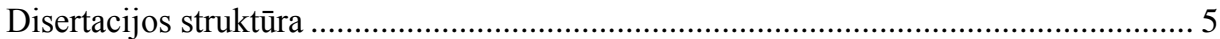

1. ŽALIAVŲ IR JŲ POVEIKIO POLIURETANO PUTŲ SAVYBĖMS MOKSLINIŲ

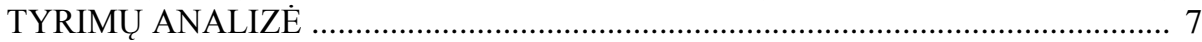

1.1. Darnusis vystymasis, koncepcija, tikslai ir iššūkiai ............................................... 7

1.2. Atsinaujinančių išteklių naudojimas - kaip viena iš priemonių darnaus

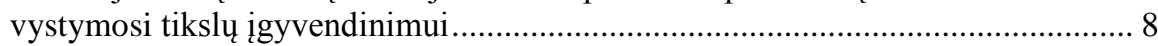

1.3. Poliuretano putų gamyboje naudojami izocianatai ir jų struktūra, poveikis gaminių fizikinèms ir mechaninèms savybèms ................................................ 15

1.4. Tradiciniai dujodariai ir jų alternatyvos ............................................................. 17

1.5. Katalizatoriai ir jų poveikis poliuretano mišinių reakcijos kinetikai ...................... 20

1.6. Paviršių aktyvinančios medžiagos. Racionalaus kiekio parinkimas ...................... 21 
1.7. Poliuretano putų struktūros modifikavimas grandinès plètikliais ......................... 21

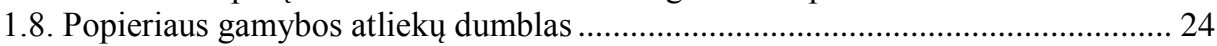

1.8.1. Popieriaus gamybos atliekų dumblo susidarymas..................................... 24

1.8.2. Popieriaus gamybos atliekų dumblo komponentų panaudojimo galimybès poliuretano putų kompozitų gamyboje.

1.9. Ivvairių užpildų poveikis poliuretano putų savybėms............................................. 27

1.10. Titanatų, silanų ir cirkonatų jungiamosios medžiagos, jų poveikis mišinių

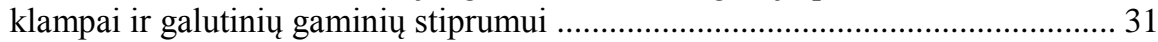

1.11. Pirmojo skyriaus išvados ir disertacijos uždavinių formulavimas ....................... 33

2. NAUDOTOS MEDŽIAGOS IR POLIURETANO PUTŲ TYRIMŲ METODAI .... 35

2.1. Tyrimams naudotos medžiagos ............................................................................ 35

2.2. Popieriaus gamybos atliekų dumblo ir poliuretano putų paruošimas tyrimams.... 40

2.3. Popieriaus gamybos atliekų dumblo dalelių, poliuretano mišinių ir modifikuotų poliuretano putu tyrimų metodai ........................................................................ 45

2.3.1. Popieriaus gamybos atliekų dumblo dalelių savybių tyrimų metodai....... 45

2.3.2. Formavimo mišinių savybių tyrimų metodai ............................................... 46

2.3.3. Nemodifikuotu ir propilenglikoliu bei popieriaus gamybos atliekų dumblo dalelèmis modifikuotų poliuretano putų tyrimų metodai .............. 48

2.4. Tyrimų rezultatų matematinis ir statistinis apdorojimas ......................................... 50

2.5. Antrojo skyriaus išvados ................................................................................. 51

3. PROPILENGLIKOLIU IR POPIERIAUS GAMYBOS ATLIEKŲ DUMBLO DALELĖMIS MODIFIKUOTŲ POLIURETANO PUTŲ STRUKTŪROS IR

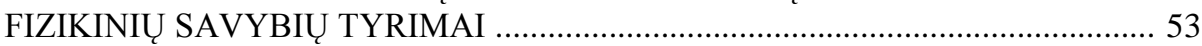

3.1. Vandens poveikis poliuretano putų fizikinėms savybėms .................................... 54

3.2. Grandinès plètiklių poveikis poliuretano putų fizikinėms ir mechaninėms savybèms

3.3. Popieriaus gamybos atliekų dumblo dalelių padengimo titanato jungiamaja

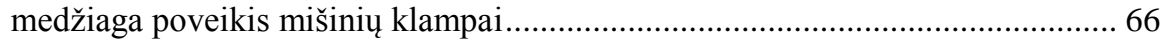

3.4. Mišinių reakcijos kinetikos ir modifikuotų poliuretano putų tariamojo tankio tyrimai 68

3.5. Modifikuotų poliuretano putų stipruminių savybių tyrimai .................................. 70

3.6. Modifikuotų poliuretano putų struktūros ir šilumos laidumo tyrimai .................... 73

3.7. Modifikuotų poliuretano putu tiesinių matmenų pokyčių tyrimai ......................... 77

3.8. Modifikuotų poliuretano putų drègminių savybių tyrimai ................................... 79

3.9. Modifikuotų poliuretano putų degumo, užsidegamumo ir terminio stabilumo

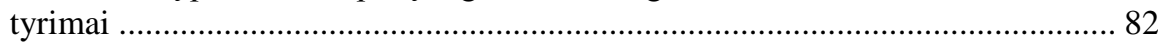

3.10. Trečiojo skyriaus išvados............................................................................ 89

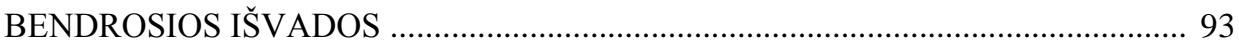

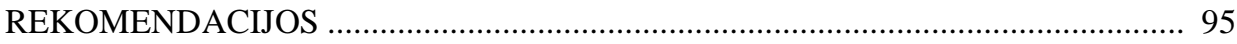

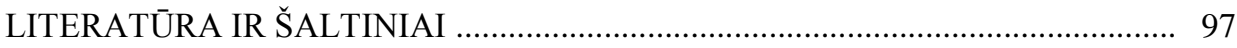

AUTORĖS MOKSLINIŲ PUBLIKACIJŲ DISERTACIJOS TEMA SĄRAŠAS .......113

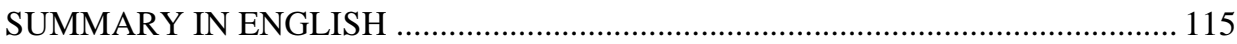

xiv 
PRIEDAI ${ }^{1}$

A priedas. Skirtingų literatūros šaltinių pateikiamos cheminès popieriaus gamybos

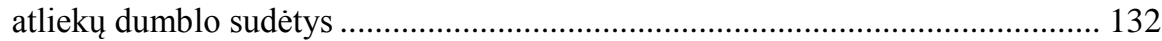

B priedas. Grandinès plètikliais modifikuotų poliuretano putų struktūriniai

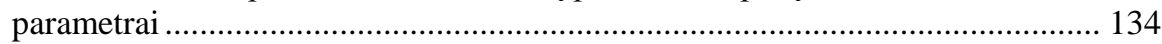

$\mathrm{C}$ priedas. Propilenglikoliu ir popieriaus gamybos atliekų dumblo dalelėmis modifikuotų poliuretano putų vidutinès šilumos laidumo koeficiento vertės ..... 135

D priedas. Disertacijos autorès sąžiningumo deklaracija .......................................... 136

E priedas. Bendraautorių sutikimai teikti publikacijose skelbtą medžiagą daktaro

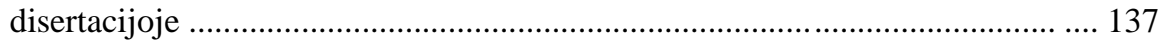

F priedas. Autorès mokslinių publikacijų disertacijos tema kopijos .......................... 142

${ }^{1}$ Priedai pateikiami pridètoje kompaktinèje plokštelèje 



\section{Contents}

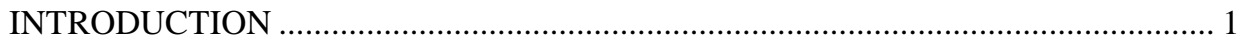

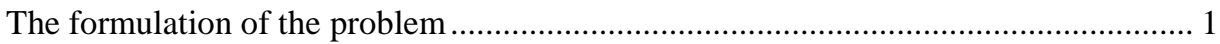

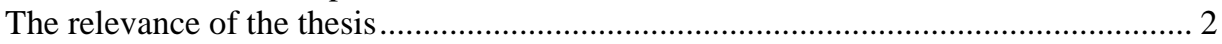

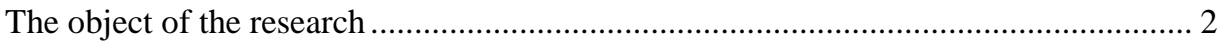

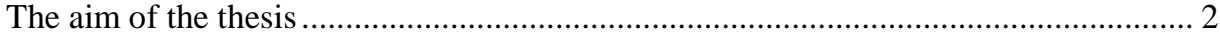

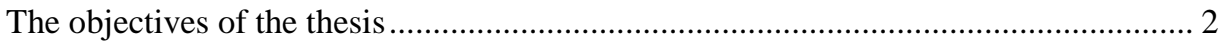

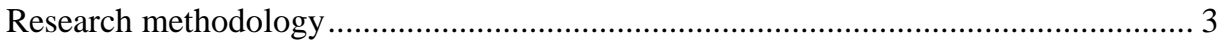

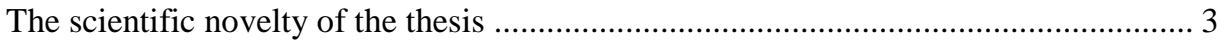

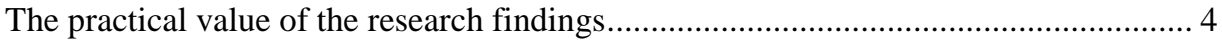

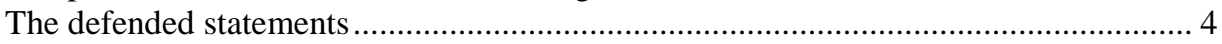

The approval of the research findings .................................................................. 5

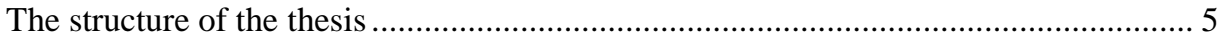

1. RESEARCH ANALYSIS OF RAW MATERIALS AND THEIR IMPACT ON

POLYURETHANE FOAM PROPERTIES ........................................................ 7

1.1. Sustainable development, concept, aims and challenges ..................................... 7

1.2. The use of renevawble resouces - one of the measures for the implementation of sustainable development aims

1.3. Isocyanates and their structure for the production of polyurethane foams, the impact on physical and mechanical properties of the products............................. 15

1.4. Traditional blowing agents and their alternatives ................................................ 17

1.5. Catalysts and their impact on reaction kinetics of polyurethane mixtures ............ 20

1.6. Surfactants. Selection of rational amount ............................................................. 21 
1.7. Modification of polyurethane foam structure by chain extenders

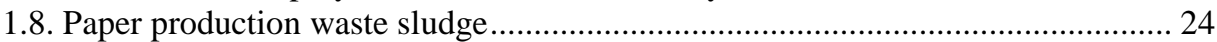

1.8.1. The formation of paper production waste sludge..................................... 24

1.8.2. The use of paper production waste sludge components for the production

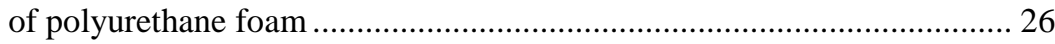

1.9. The impact of various fillers on properties of polyurethane foams ....................... 27

1.10. Titanate, silane and zirconate coupling agents, their impact on mixture viscosity and strength of the final products

1.11. Conclusions of the first chapter and formulation of the objectives of the thesis. 33

2. MATERIALS AND RESEARCH METHODOLOGIES OF POLYURETHANE FOAM

2.1. The materials used for the investigation

2.2. Preparation for the research of paper production waste sludge and polyurethane foam

2.3. Research methodologies of paper production waste sludge particles, polyurethane mixtures and modified polyurethane foam

2.3.1. Research methodologies of paper production waste sludge particles properties

2.3.2. Research methodologies of forming mixtures properties

2.3.3. Research methodologies of control, propylene glycol extended and paper production waste sludge particles modified polyurethane foams............... 48

2.4. Mathematical and statistical processing of the obtained results............................ 50

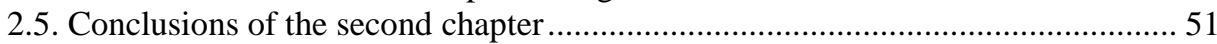

3. RESEARCH OF STRUCTURE AND PHYSICAL PROPERTIES OF PROPYLENE GLYCOL EXTENDED AND PAPER PRODUCTION WASTE SLUDGE PARTICLES MODIFIED POLYURETHANE FOAMS ......................................... 53

3.1. The impact of water on physical properties of polyurethane foam ........................ 54

3.2. The impact of chain extenders on physical and mechanical properties of

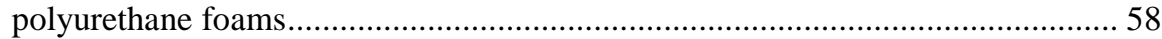

3.3. The impact of titanate coupling agent coated paper waste sludge particles on

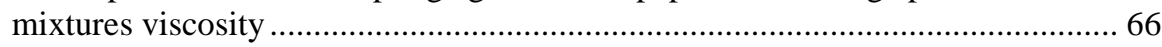

3.4. Research of mixtures reaction kinetics and apparent density of modified

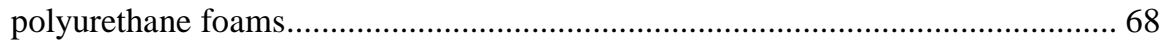

3.5. Research of strength properties of modified polyurethane foams ........................ 70

3.6. Research of thermal conductivity and structure of modified polyurethane

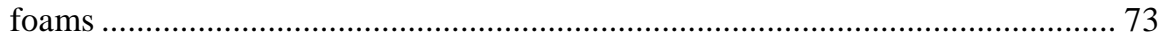

3.7. Research of changes in linear dimensions of modified polyurethane foams ........ 77

3.8. Research of moisture properties of modified polyurethane foams....................... 79

3.9. Research of flammability, ignitability and thermal stability of modified

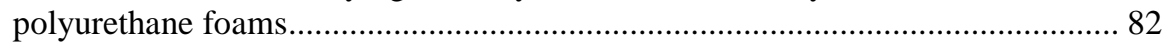

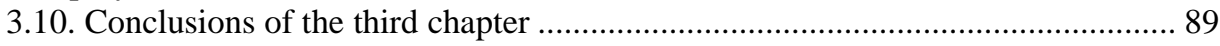

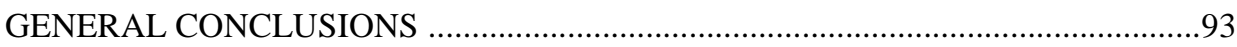

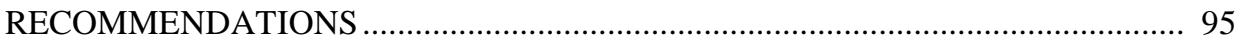


THE LIST OF SCIENTIFIC PUBLICATIONS BY THE AUTHOR ON THE

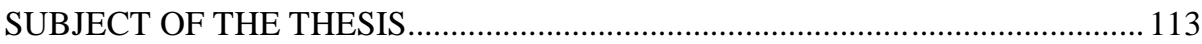

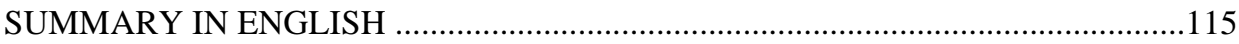

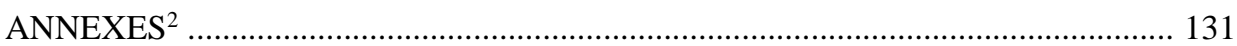

Annex A. Chemical compositions of paper production waste sludge presented by different references ................................................................................... 132

Annex B. Structural parameters of chain extenders modified polyurethane foams ... 134

Annex C. Average values of thermal conductivity of propylene glycol and paper production waste sludge particles modified polyurethane foams ........................ 135

Annex D. Author's declaration of academic integrity ............................................. 136

Annex E. The co-authors' agreements for providing the material of the joint

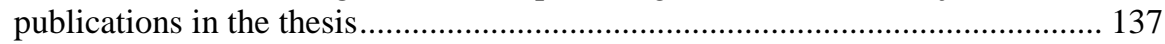

Annex F. Copies of the scientific publications by the author on the subject of the thesis

${ }^{2}$ The annexes are provided in the enclosed compact disc 



\section{Ivadas}

\section{Problemos formulavimas}

Poliolis, skirtas standžiuju poliuretano putų gamybai, turi tenkinti tam tikrus reikalavimus - atitinkamų funkcinių grupių skaičius turi būti $>3$, molekulinè masè $<1200$ g/mol, o hidroksilų skaičius kisti nuo $350 \mathrm{mg} \mathrm{KOH/g} \mathrm{iki} 600 \mathrm{mg} \mathrm{KOH/g}$. Tenkindami šiuos reikalavimus, polioliai iš atsinaujinančių išteklių tampa pigi ir ekologiška alternatyva tradiciniams polioliams iš naftos produktų.

Atsižvelgdami ị ozono sluoksnio mažinimo (ODP) ir globalinio atšilimo potencialus (GWP), teisès aktai lemia ir kitų standžiosiose poliuretano putose naudojamų medžiagų - dujodarių - pakeitimo ne tokiomis agresyviomis alternatyvomis galimybes bei naudojimo terminus. Vanduo ODP, GWP, kainos ir naudojimo paprastumo bei laikymo atžvilgiais yra viena patraukliausių alternatyvų poliuretano putų gamyboje. Tačiau galutinis poliuretano gaminys, kuomet naudojami polioliai netenkina minètų reikalavimų, pasižymi netinkama pradine susitrauktimi $23{ }^{\circ} \mathrm{C}$ temperatūros ir $50 \%$ santykinès drègmès (toliau pradinè susitrauktis) ir matmenų stabilumu $70{ }^{\circ} \mathrm{C}$ temperatūros bei $90 \%$ santykinès drègmès aplinkose (toliau matmenų stabilumas padidintos temperatūros ir drègmès sąlygomis). Tai itin aktualu apšiltinant pramoninius ir gyvenamuosius didelio tūrio pastatus. Šiuo atžvilgiu dideli matmenų pokyčiai lemtų plyšių tarp izoliuojamo ir izoliacinio pa- 
viršių atsiradimą, dèl ko poliuretano putos nebeatitiktų savo, kaip termoizoliacinès medžiagos, paskirties. Tokiose konstrukcijose lengvai kauptųsi drègmè, sukeltos deformacijos ardytų apdailinị pastato sluoksnị ir kt.

\section{Darbo aktualumas}

Viena iš pagrindinių Europos Komisijų strategijų - sumažinti šiltnamio efektą sukeliančių dujų išsiskyrimą $20 \%$ iki 2020 metų ir $80 \%$ iki 2050 metų. Todèl, didejant pastatų energinio naudingumo reikalavimams, kuriuos apima ne tik statybinių medžiagų šiluminių savybių gerinimas, bet ir medžiagų gamybos bei ịrengimo sąnaudos, statybinių medžiagų sektoriuje didèja ne tik energetiškai, bet ir ekologiškai efektyvių medžiagų poreikis. Atsinaujinančių išteklių ir ypatingai pramonès atliekų panaudojimas yra puiki alternatyva naftos produktams termoizoliacinių medžiagų gamyboje. Vienas iš 17 darniojo vystymosi tikslų - atliekų mažinimas, jų pakartotinis panaudojimas, todèl vis intensyviau ieškoma būdų, kaip susidarantị popieriaus gamybos atliekų dumblą panaudoti tose pačiose ar kitose pramonès srityse, gauti gaminius, pasižyminčius tokiomis pat ar geresnèmis savybèmis.

Ekologiniu požiūriu poliolių iš atsinaujinančių išteklių, vandens bei neorganinių ir organinių atliekų sistemos panaudojimas standžiosiose poliuretano putose šiuo metu yra labai aktualus. Norint tokius gaminius naudoti statybų pramonėje, būtini moksliniai tyrimai, kurie leistų nustatyti galimybes gauti matmenų atžvilgiu stabilius gaminius, atitinkančius ekologinio ir energinio efektyvumo principus.

\section{Tyrimų objektas}

Poliuretano putos, susintetintos iš rapsų aliejaus poliolių ir modifikuotos popieriaus gamybos atliekų dumblo dalelèmis.

\section{Darbo tikslas}

Sukurti ir ištirti stabilias poliuretano putas, susintetintas iš rapsų aliejaus poliolių ir modifikuotas popieriaus gamybos atliekų dumblo dalelèmis.

\section{Darbo uždaviniai}

Užsibrèžtam darbo tikslui pasiekti reikia spręsti šiuos uždavinius: 
1. Ištirti vandens, kaip dujodario, kiekio poveiki poliuretano putu pradinei susitraukčiai, matmenų stabilumui padidintos temperatūros ir drègmès sąlygomis bei tankiui.

2. Ištirti propilenglikolio iš rapsų glicerino ir rapsų glicerino poveiki standžiujjų poliuretano putų fizikinèms ir mechaninèms savybèms.

3. Ištirti titanato jungiamaja medžiaga padengtų popieriaus gamybos atliekų dumblo dalelių poveikį propilenglikoliu modifikuotų poliuretano putų reakcijos kinetikai, fizikinèms, mechaninėms ir cheminèms savybèms.

4. Pateikti rekomendacijas ribiniams propilenglikolio iš rapsų glicerino ir termiškai bei chemiškai apdorotų popieriaus gamybos atliekų dumblo dalelių kiekiams pagal būsimų gaminių gamybos pobūdị, atsižvelgiant ị modifikuotų mišinių reologiją bei fizikines gaminių savybes.

\section{Tyrimų metodika}

Popieriaus gamybos dumblo dalelių tyrimams buvo taikyti standartiniai birių medžiagų piltinio tankio, paviršiaus ploto, šilumos laidumo koeficiento, dalelių dydžio ir drègmès kiekio nustatymo metodai.

Termiškai ir chemiškai apdorotų popieriaus gamybos atliekų dumblo dalelių kiekybinès ir kokybinès suděčių nustatymui buvo naudoti rentgenostruktūinės ir rentgeno fluorescencinès, termogravimetrinès ir diferencinès terminès analizių metodai.

Standžiujų poliuretano putų, modifikuotų propilenglikoliu ir popieriaus gamybos atliekų dumblo dalelėmis, tyrimams buvo taikytos tariamojo tankio, gniuždymo ir tempimo stiprių, šilumos laidumo koeficiento, pradinès susitraukties, matmenų stabilumo, pralaidumo vandens garams, ilgalaikès vandens sugerties visiškai jame panardinus, degumo, užsidegamumo ir terminio stabilumo nustatymo metodikos.

Struktūros tyrimams ir struktūrinių parametrų nustatymui buvo taikyta skenuojanti elektroninė mikroskopija, uždarų akučiu procentinio kiekio nustatymo ir kietujų bei minkštųų segmentų skaičiavimo metodikos. Rezultatų apdorojimui ir patikimumo ịvertinimui buvo taikyti matematiniai ir statistiniai metodai.

\section{Darbo mokslinis naujumas}

Rengiant disertaciją, buvo gauti šie medžiagų inžinerijos mokslui nauji rezultatai: 
1. Nustatyta standžiujų poliuretano putų tariamojo tankio priklausomybė nuo vandens kiekio, leidžianti prognozuoti būsimų gaminių vidutines tankio vertes be išankstinių pradinių tyrimų.

2. Propilenglikolis iš rapsų glicerino igalina sudaryti ekologinio efektyvumo $^{3}$ principus atitinkančių gaminių sudètį ir reguliuoti šių gaminių struktūrą bei savybes.

3. Nustatyti propilenglikolio kiekiai leidžia naudoti nuo 1,5 iki 2 kartų didesni popieriaus gamybos atliekų dumblo kiekị ir gauti matmenų atžvilgiu stabilias modifikuotas poliuretano putas, sutrumpinant išlaikymo po gamybos laiką iki 24 val. Popieriaus gamybos atliekų dumblo dalelès padidina gaminių stiprumą ir atsparumą degumui.

\section{Darbo rezultatų praktinė reikšmė}

Tyrimų rezultatai gali būti naudojami iš mažą funkcinių grupių skaičių turinčių augalinès kilmès aliejų poliolių pagamintų tradicinių bei popieriaus gamybos atliekų dumblo dalelèmis modifikuotų poliuretano putų matmenų stabilizavimui po gamybos ir, priklausomai nuo panaudojimo srities, padidintos temperatūros ir drègmès sąlygomis.

Sukurtos modifikuotos poliuretano putos gali būti naudojamos kaip šilumą izoliuojantis sluoksnis pastatų atitvarų konstrukcijose bei tose konstrukcijose, kuriose nepasireiškia ilgalaikis tiesioginis vandens poveikis.

\section{Ginamieji teiginiai}

1. Propilenglikolis leidžia kontroliuoti standžiujų poliuretano putų matmenų pokyčius, užtikrindamas visiškai arba iš dalies atviraporès struktūros formavimąsi.

2. Popieriaus gamybos atliekų dumblo dalelès ir jų aglomeratai veikia kaip barjeras liepsnos plitimui standžiosiose poliuretano putose, veikiant gaminius atvira liepsna, ir užtikrina mažesnị šilumos bei toksinių dujų išsiskyrimą degimo metu.

\footnotetext{
${ }^{3}$ Ekologinis efektyvumas - atsinaujinančių išteklių produktyvumo didinimas gamybos procese.
} 


\section{Darbo rezultatų aprobavimas}

Disertacijos tema yra atspausdinti 5 moksliniai straipsniai: vienas - mokslo žurnale, ittrauktame ị Clarivate Analytics Web of Science duomenų bazę (Kairytè, Vejjelis 2015); trys - kitų tarptautinių bazių žurnaluose (Kairytè et al. 2016, Kairytė et al. 2017a, Kairytė 2017), vienas - recenzuojamoje tarptautinès konferencijos medžiagoje (Kairytè et al. 2017b).

Disertacijoje atliktų tyrimų rezultatai buvo paskelbti šešiose mokslinėse konferencijose Lietuvoje ir užsienyje:

- "The 9th World Congress on Materials Science and Engineering", 2017 m., Roma, Italija;

- 20-oji jaunujų mokslininkų konferencija „Mokslas - Lietuvos ateitis“, 2017 m., Vilnius, Lietuva;

- "The 25th International Baltic Conference of Engineering Materials and Tribology", 2016 m., Ryga, Latvija;

- 19-oji Lietuvos jaunujų mokslininkų konferencija „Mokslas - Lietuvos ateitis“, 2016 m., Vilnius, Lietuva;

- 5-oji Lietuvos jaunujų mokslininkų konferencija „Fizinių ir technologijos mokslų tarpdalykiniai tyrimai“", 2015 m., Vilnius, Lietuva;

- 17-oji Lietuvos jaunujų mokslininkų konferencija „Mokslas - Lietuvos ateitis“, 2014 m., Vilnius, Lietuva.

\section{Disertacijos struktūra}

Disertaciją sudaro įvadas, trys skyriai, bendrosios išvados, literatūros ir disertacijos autorès publikacijų sąrašai.

Darbo apimtis (be priedų) yra 131 puslapis, tekste panaudotos 21 numeruota formulè, 35 paveikslai ir 21 lentelè. Rašant disertaciją buvo panaudota 197 literatūros šaltinių. 



\section{1}

\section{Žaliavų ir jų poveikio poliuretano putų savybẻms mokslinių tyrimų analizè}

Skyriuje aptariamas pagrindinès žaliavos - poliolio iš atsinaujinančių išteklių, kaip dar vienos priemonès, prisidèsiančios prie darnaus vystymosi tikslų igyvendinimo, gamyba ir panaudojimas poliuretano putų sintezèje. Analizuojamas papildomų poliuretano putų žaliavų poveikis galutinių gaminių struktūrai ir savybèms, taip pat popieriaus gamybos atliekų dumblo dalelès, jų cheminé sudètis ir panaudojimo termoizoliacinių polimerinių putų gamyboje galimybès. Skyriaus tematika paskelbtas vienas autorès straipsnis (Kairytė 2017).

\subsection{Darnusis vystymasis, koncepcija, tikslai ir iššūkiai}

Darniojo vystymosi, kaip vystymosi, kuris tenkina dabartinius visuomenès poreikius, nemažinant ateinančių kartų galimybių tenkinti savuosius, koncepciją apibréžè pasaulinė aplinkos ir plètros komisija. Šios koncepcijos igyvendinimui 180 šalių atstovai Rio De Žaneire prièmė visapusišką darnaus vystymosi veiksmų 
planą, kuriame skatinamas aplinkai saugus ir darnus atsinaujinančių išteklių naudojimas. 2006 metais Europos Sajungos (ES) taryba atnaujino ES darnaus vystymosi strategiją, kurioje vienas iš pagrindinių aplinkosaugos tikslų - užkirsti kelią aplinkos taršai, ją sumažinti bei skatinti darnų vartojimą ir gamybą, kurie tenkintų aplinkosaugos reikalavimus, keliamus ekonomikos augimui (EST 2006).

Nacionaline darnaus vystymosi strategija Lietuvoje teigia, kad itin svarbus Lietuvos darniojo vystymosi prioritetas - pagrindinių ūkio šakų, pavyzdžiui, statybos, energetikos, žemès ūkio pramoniu ir t. t. poveikio aplinkai mažinimas per jų ekologinio efektyvumo didinimą (LRV 2011).

2015 m. rugsèjo mèn. 25 d. Jungtinès Tautos sudarè darbotvarkę iki 2030 metų, kurioje numatė 17 darnaus vystymosi tikslų ir 169 uždavinius šiems tikslams igyvendinti. Vienas iš šių tikslų numato užtikrinti darnius vartojimo ir gamybos modelius, t. y. iki 2020 metų užtikrinti aplinkai kenksmingų chemikalų ir visų atliekų tvarkymą per visą jų gyvavimo ciklą bei žymiai sumažinti jų išmetimą i orą, vandenị ir dirvožemị, taip pat iki 2030 metų sumažinti atliekų susidarymą, taikant prevenciją, mažinimą, perdirbimą ir pakartotinị panaudojimą (General Assembly, 2015). Aplinkosaugos agentūra įvedè terminą, kuris apėmė svarbiausius darnumo, susijusio su chemijos mokslu, principus - „Žalioji chemija“ (angl. Green chemistry). Buvo suformuluota 12 principų, iš kurių pagrindiniai yra:

1. Skatinti inovatyvias chemijos technologijas, mažinančias ar šalinančias pavojingų medžiagų ar junginių naudojimą ir išsiskyrimą projektavimo, modeliavimo, gamybos ar cheminès medžiagos naudojimo metu;

2. Sukurti ir priimti inžinerinius sprendimus, mažinančius energijos suvartojimą;

3. Mažinti naudojamus išteklius ir atliekų kaupimąsi, naudojant efektyvius katalizinius procesus;

4. Naudoti atsinaujinančius išteklius ir subproduktus, išgaunamus kitose, ne ribotose, srityse.

\subsection{Atsinaujinančių ištekliụ naudojimas - kaip viena iš priemonių darnaus vystymosi tikslụ igyvendinimui}

Poliuretano putos yra gaunamos cheminès reakcijos metu, kuomet reaguoja hidroksilų grupes turinčios medžiagos, vadinamos polioliais, ir izocianatai (1.1 pav.). Struktūros stabilizavimui papildomai naudojamos paviršių aktyvinančios medžia- 
gos, reakcijų spartinimui - katalizatoriai, akytosios struktūros formavimui - dujodariai ir degumo charakteristikų užtikrinimui - degumą slopinančios medžiagos.

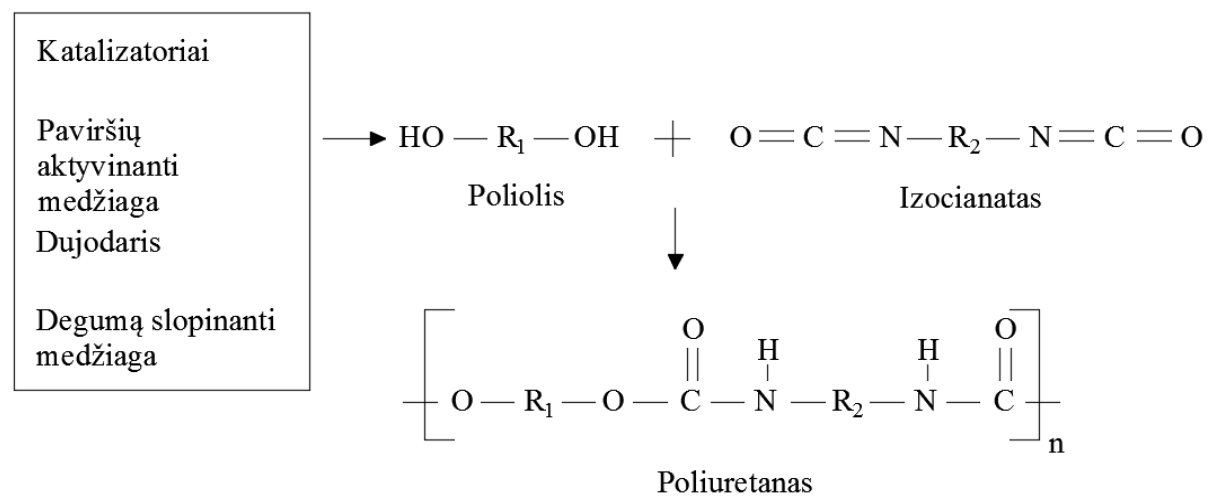

1.1 pav. Struktūrinė poliuretano putu sintezės schema (Kirpluks et al. 2016)

Fig. 1.1. Structural scheme of polyurethane foam synthesis (Kirpluks et al. 2016)

Vienas iš šiuo metu pagrindinių Europos Sajungos teisès aktų nuostatų ir Kijoto Protokolo tikslų yra sumažinti šiltnamio efektą sukeliančių dujų išsiskyrimą. Pakankamai paprastas ir elementarus būdas stabdyti pernelyg didelę $\mathrm{CO}_{2}$ dujų emisiją yra naudoti energiją ir žaliavas iš atsinaujinančių išteklių, todèl poliuretano putu gamyboje naudojamas poliolis iš naftos produktų yra keičiamas polioliu iš atsinaujinančių išteklių, fluorinti ir chlorinti angliavandeniliai - vandeniu, o bromintos ir halogenintos degumą slopinančios medžiagos - neorganiniais užpildais.

Atsinaujinančių išteklių naudojimas cheminių medžiagų sintezejje sumažina neigiamą poveikị aplinkai - ribotų išteklių naudojimą ir šiltnamio efektą sukeliančių dujų išsiskyrimą. Šie ištekliai atveria galimybes iš dalies arba visiškai pakeisti polimerus iš naftos produktų, kurie gali konkuruoti ar net pranokti tradicines medžiagas kainos, kokybės ir poveikio aplinkai atžvilgiu.

Augalinès kilmès aliejai yra atsinaujinantys ištekliai, kurie gali būti naudojami kaip pradinè medžiaga ịvairiomis struktūrinėmis ir funkcinėmis variacijomis pasižyminčių gaminių kūrimui. Gausa, prieinamumas ir santykinai žema kaina daro augalinius aliejus patrauklia žaliava plastiko pramoneje. Šie aliejai ir iš jų išgaunamos riebalų rūgštys yra laikomi svarbiausiomis atsinaujinančiomis žaliavomis chemijos pramonejje ir ekologiškų funkcinių polimerų bei polimerinių medžiagų gamyboje (Miao et al. 2014; Alam et al. 2014; Pillai et al. 2016).

Kasmetinè pasaulinė augalinių aliejų (palmių vaisių, sojų, rapsų, saulègrąžų, palmių vaisių sẻklų, alyvuogių ir kokosų) gamyba sudare 175,7 milijonus tonų 2014-2015 metais, nuo 2000 metų iki 2015 metų šių aliejų gamyba išaugo $94 \%$. 
Daugiausiai pasaulyje pagaminama palmių, sojų, rapsų ir saulègrąžų aliejaus (1.2 pav.).

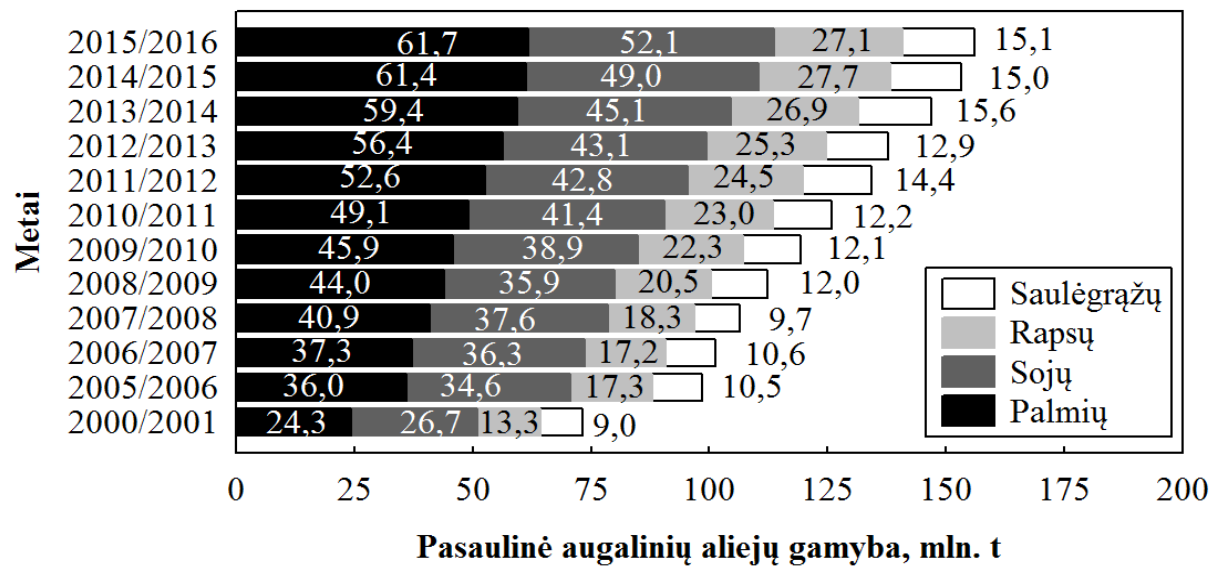

1.2 pav. Pasaulinė augalinių aliejų gamyba nuo 2000 metų iki 2015 metų (Statista 2016)

Fig. 1.2. Worldwide production of vegetable oils from 2000 to 2015 (Statista 2016)

Augaliniai aliejai yra trigliceridai - glicerino esteriai, turintys tris ilgagrandines karboksilinių rūgščių molekules, vadinamas riebalų rūgštimis. Šios rūgštys dažniausiai yra nešakotos ir turi lygini anglies atomų skaičiu (tarp 16 ir 20) bei skiriasi ịsotinimu dvigubomis jungtimis nuo 0 iki 3 (1.3 pav.). Tam tikrõs triglicerido molekulès minètosios trys riebalų rūgštys nebūtinai bus vienodos, o dèl aliejų îvairovès, tikètina, juos sudarys kompleksinis skirtingų trigliceridų mišinys. Sočiosioms riebalų rūgštims priklauso palmitino (C16:0) ir stearino (C18:0) rūgštys.

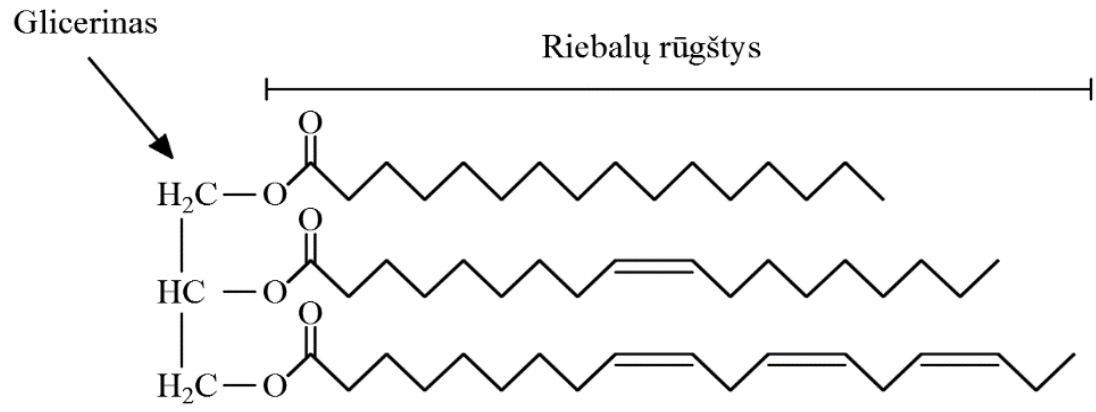

1.3 pav. Triglicerido molekulès pavyzdys (Li et al. 2015)

Fig. 1.3. An example of triglyceride molecule (Li et al. 2015) 
Nesočiosioms riebalų rūgštims priklauso oleino (C18:1), linolo (C18:3) ir linoleno (C18:3) rūgštys (pirmasis skaičius nurodo anglies atomų kiekị, antrasis - dvigubų jungčių kieki). Būtent karboksilinių rūgščių grupès ir nesočiosios $\mathrm{C}=\mathrm{C}$ dvigubosios jungtys yra vienintelès gamtoje randamos funkcinès grupès. Išimtị sudaro ricinolio rūgštis, kurios ricinos aliejuje yra $87 \%$. Ši rūgštis jau turi hidroksilo grupių $\mathrm{C} 12$ vietoje ir $\mathrm{C}=\mathrm{C}$ dvigubają jungti tarp C9 ir C10 (Madbouly et al. 2016). Tai reiškia, kad ricinos aliejus yra vienintelis gamtoje randamas natūralus poliolis, kurio gamybai nebereikalinga cheminè modifikacija. Augalinès kilmès poliolių gamyboje būtina $\mathrm{C}=\mathrm{C}$ dvigubų jungčių ar esterinių grupių konversija ị hidroksilo grupes. Šis procesas nagrinètas, naudojant ịvairius aliejus - palmiu (Pawlik, Prociak 2011; Tanaka et al. 2008), sojų (Campanella et al. 2009; Gu, Sain 2013), rapsų (Rojek, Prociak 2012; Šulcienè et al. 2014), ricinų (Mosiewicki et al. 2009; Wik et al. 2011) ir tokių medžiagų kaip melasa (Hatakeyama et al. 2011), kukurūzų ir bulvių krakmolas ar kviečiai (David et al. 2009). Iš šiu aliejų gautų poliolių cheminè formulè pateikta 1.4 paveiksle.

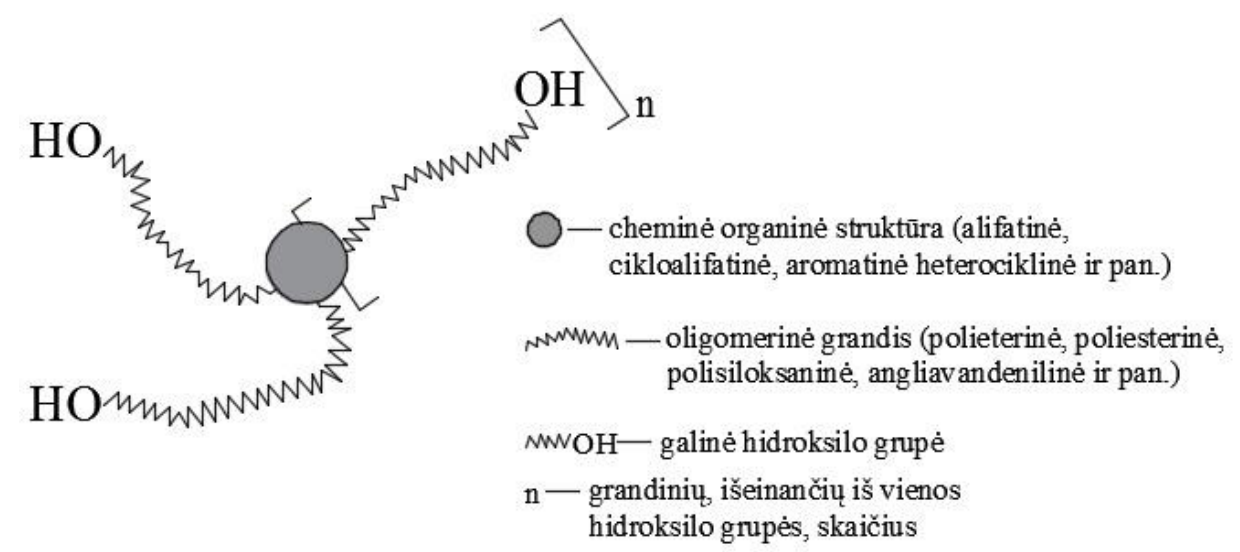

1.4 pav. Cheminè poliolių, skirtų poliuretanams, formulè (Ionescu 2005)

Fig. 1.4. Chemical formula of polyols for polyurethane (Ionescu 2005)

Poliolio struktūros, suformuotos skirtingais metodais, turi didelị poveikị poliolio reaktyvumui, o taip pat ir poliuretano putų savybėms. Šiuo metu polioliai iš augalinès kilmès aliejų gali būti gaminami epoksidacijos - oksirano žiedo atidarymo (Zieleniewska et al. 2015), ozonolizès - redukcijos (Ionescu et al. 2012), hidroformilinimo - redukcijos (Guo et al. 2002), transesterifikacijos (Fridrihsone et al. 2013), amidizacijos (Kirpluks et al. 2013), hidrogenacijos (Sonnen- 
schein, Wendt 2013) ir chemo - fermentiniu (transesterifikacija fermentais) (Šulcienè et al. 2014) būdais. Visi augalinès kilmès polioliai, išskyrus tuos, kurie suformuoti ozonolizès metodu, pasižymi „kabančiosiomis“ grandimis, kurios veikia kaip plastifikatoriai ir gali turèti neigiamą poveikị galutinėms gaminio savybėms. Narine et al. 2007 tyrè „kabančiujų“ grandžių polioliuose iš rapsų, ricinos ir sojų aliejų poveiki poliuretano putų savybèms ir nustatè, kad prastesnèmis stipruminèmis savybėmis pasižymèjo poliuretano putos iš sojų ir rapsų aliejų poliolių, kuriuos sudaro ne tik antrinès funkcinès hidroksilų grupès, bet ir ilgesnès „,kabančiosios" grandys, dèl kurių padidèja poliolių iš sojų ir rapsų aliejų terminis stabilumas.

Molekulinè masė, funkcionalumas ir hidroksilų skaičius yra pagrindiniai ir patys svarbiausi poliolio parametrai, lemiantys poliuretano putų savybes, todèl mokslininkai (Zlatanić et al. 2004) ištyrè 6 pagrindinių aliejų struktūros poveikị minètiesiems poliolių iš augalinès kilmès aliejų parametrams (1.1 lentelè).

1.1 lentelè. Pagrindinès augalinių aliejų pagrindu pagamintų poliolių savybès (Zlatanić et al. 2004)

Table 1.1. The main properties of polyols from vegetable oils (Zlatanić et al. 2004)

\begin{tabular}{|l|c|c|c|}
\hline $\begin{array}{c}\text { Pradinė medžiaga polio- } \\
\text { lio gamybai }\end{array}$ & $\begin{array}{c}\text { Poliolio hidroksilu } \\
\text { skaičius, mg } \\
\text { KOH/g* }\end{array}$ & $\begin{array}{c}\text { Poliolio } \\
\text { molekulinè } \\
\text { masė, g/mol* }\end{array}$ & $\begin{array}{c}\text { Poliolio funk- } \\
\text { cionalumas, }^{*} \text { b. d. }^{*}\end{array}$ \\
\hline Rapsų aliejus & 173,6 & 1123 & 3,30 \\
\hline $\begin{array}{l}\text { Vidutinio oleino kiekio } \\
\text { saulėgrąžu aliejus }\end{array}$ & 163,5 & 1191 & 3,08 \\
\hline Sojų aliejus & 179,3 & 1249 & 3,47 \\
\hline Sėmenų aliejus & 247,8 & 1274 & 5,21 \\
\hline Saulėgrąžu aliejus & 177,8 & 1302 & 3,47 \\
\hline Kukurūzų aliejus & 179,0 & 1180 & 3,44 \\
\hline
\end{tabular}

$\left.{ }^{*}\right)$ Kitų autorių pagamintų poliolių cheminių savybių skaitinès vertés gali skirtis.

Autoriai Kong et al. 2013 ištyrè poliuretano putas, kurių gamyboje naudoti polioliai iš rapsų (hidroksilų skaičius $259 \mathrm{mg} \mathrm{KOH} / \mathrm{g}$ ), saulègrąžų (hidroksilų skaičius $286 \mathrm{mg} \mathrm{KOH/g}$ ), kamelinos (Europoje ir vidurinès Azijos dalyje auginamas augalas, hidroksilų skaičius $272 \mathrm{mg} \mathrm{KOH} / \mathrm{g}$ ) ir linų sėmenų (hidroksilų skaičius $292 \mathrm{mg} \mathrm{KOH} / \mathrm{g}$ ) aliejų. Paaiškejo, kad didesniais tempimo ir gniuždymo stipriais, tamprumo moduliais bei terminiu stabilumu pasižymèjo putos, kurių gamyboje naudoti polioliai turèjo didesnį hidroksilų skaičių. Esant panašiam hidroksilų skaičiui $\sim 365 \pm 15 \mathrm{mg} \mathrm{KOH} / \mathrm{g}$, tačiau funkcionalumui didejjant nuo $2 \mathrm{iki}$ 5,6, didèja poliolio klampa. To priežastimi yra tarpmolekulinès vandenilio jungties formavimasis, nes, didejjant hidroksilų skaičiui molekuleje, molekulinis paslankumas mažèja. Kuo didesnis poliolio funkcionalumas, tuo didesnis skersines 
grandis sukuriančių medžiagų tankis. Tai lemia didesnị poliuretano putų tankị bei gniuždymo stiprị (Xiaobin et al. 2008). Tuo tarpu Tu et al. 2007 nustate, kad hidroksilų skaičiaus vertè neturi jokio poveikio šilumos laidumo koeficientui, nes ši parametrą lemia dujų, esančių akutèse, šilumos laidumo koeficientas, akučių dydis, uždarų akučių procentinis kiekis, akutèse esančių dujų konvekcija, medžiaga, iš kurios suformuota polimerinè matrica, gaminio tankis bei šiluminis spinduliavimas.

Gerai žinoma, kad hidroksilų skaičius lemia skersinių jungčių tankị, todèl pastebėtas akivaizdus poveikis gaminių gniuždymo stipriui. Didejjant hidroksilų skaičiaus vertei nuo $250 \mathrm{mg} \mathrm{KOH} / \mathrm{g}$ iki $490 \mathrm{mg} \mathrm{KOH} / \mathrm{g}$, poliuretano putų gniuždymo stipris padidèjo nuo $80 \mathrm{kPa}$ iki $400 \mathrm{kPa}$. Taip pat buvo pastebèta, kad poliuretano putos, kuriose naudotas mažą hidroksilų skaičiaus vertę turintis poliolis ( $<290 \mathrm{mg} \mathrm{KOH} / \mathrm{g}$ ), pasižymèjo didele pradine susitrauktimi bei netinkamu matmenų stabilumu padidintos temperatūros ir drégmès sąlygomis (1.5 pav.).

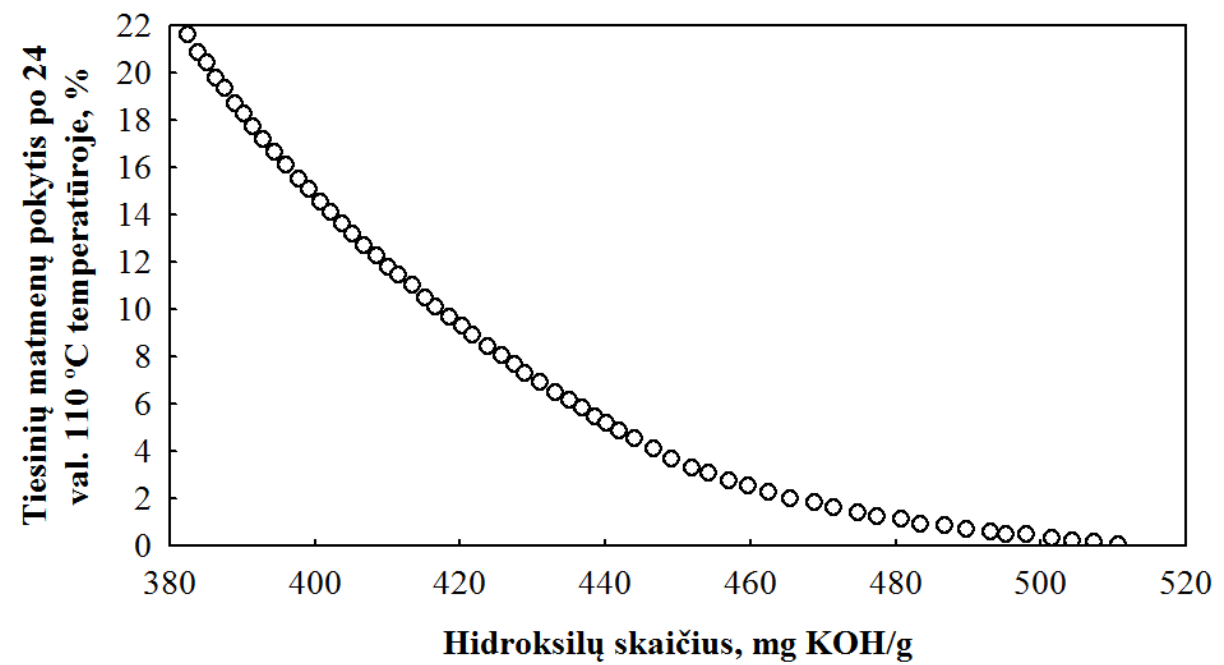

1.5 pav. Poliuretano putų tiesinių matmenų pokyčio priklausomybè nuo poliolio hidroksilų skaičiaus vertès (Tu et al. 2007)

Fig. 1.5. Dependence of polyurethane foam changes in linear dimensions on polyol hydroxyl value (Tu et al. 2007)

Mokslininkai Stirna, Cabulis 2008, naudodami transesterifikacijos metodą, pagamino poliolius iš įvairių aliejų (rapsų, sėmenų, saulėgrąžų ir ricinų) ir ištyrè jų bei izocianato indekso poveikị fizikinèms ir mechaninèms poliizocianurato putų savybèms ir palygino jas su to paties gaminio iš naftos produktų poliolio savybèmis. Rezultatai rodo, kad augalinių aliejų pagrindu gautų galutinių gaminių fizikinès ir mechaninès savybès yra labai panašios į naftos produktų pagrindu 
gautų gaminių savybes, t. y. tankis kito nuo $48,2 \mathrm{~kg} / \mathrm{m}^{3} \mathrm{iki} 51,7 \mathrm{~kg} / \mathrm{m}^{3}$, gniuždymo stipris - nuo $140 \mathrm{kPa}$ iki $190 \mathrm{kPa}$, tempimo stipris - nuo $220 \mathrm{kPa}$ iki $230 \mathrm{kPa}$, vandens sugertis visiškai jame panardinus 7 paras - nuo $1,36 \%$ iki 2,82 \%. Didèjant izocianato indeksui nuo 150 iki 300, gaminys pasižymèjo $14 \%$ mažesniu tankiu, tačiau $29 \%$ didesniu gniuždymo stipriu bei 6 kartus didesne vandens sugertimi visiškai jame panardinus 7 paras. Nesureagavusios su poliolio $(-\mathrm{OH})$ grupėmis, izocianato $(-\mathrm{NCO})$ grupès padidina galutinio gaminio hidrofiliškumą, o tai reiškia, kad poliizocianurato putų gaminiai pasižymi didesne vandens sugertimi, todèl optimaliomis savybėmis pasižymėjo tos putos, kurių sudèties skaičiavimuose naudojamas izocianato indeksas yra $150 \div 200$ ribose.

Autoriai Zhang et al. 2014 atkreipè dėmesį, kad augalinès kilmès poliolių naudojimas poliuretano ir poliizocianurato putų gamyboje yra ribotas dèl prastų degumo charakteristikų, todèl pabandè susintetinti poliolị iš ricinų aliejaus ir trifenilo fosfino kaip degumą slopinančią medžiagą. Paaiškèjo, kad galutinio gaminio gniuždymo stipris padidèjo labai nežymiai, t. y. $\sim 10 \mathrm{kPa}$, esant beveik tam pačiam tankiui, tačiau pagerèjo terminis stabilumas.

Termogravimetriné analizé parodè, kad anglingosios liekanos $700{ }^{\circ} \mathrm{C}$ temperatūroje padidejo beveik $16 \%$, o terminis putų su degumą slopinančia medžiaga suirimas yra panašus ị putų be degumą slopinančios medžiagos $\left(\sim 250^{\circ} \mathrm{C}\right)$.Poliuretano putos iš augalinès kilmès aliejų poliolių pasižymi itin didele pradine susitrauktimi ir prastu matmenų stabilumu padidintos temperatūros ir drègmės sąlygomis, kai vanduo naudojamas kaip dujodaris (Badri et al. 2001), todèl mokslininkai Septevani et al. 2015 tradicini polieterini polioli bandè iš dalies pakeisti poliesteriniu polioliu iš palmių aliejaus. Gauti rezultatai parodè, kad tradicini polieterinị polioli iš naftos produktų $50 \%$ galima pakeisti polioliu iš palmių aliejaus. Tokios poliuretano putos pasižymėjo mažesniu šilumos laidumo koeficientu nei putos iš tradicinio poliolio, t. y. nuo $0,0266 \mathrm{~W} /(\mathrm{m} \cdot \mathrm{K})$ sumažèjo iki $0,0258 \mathrm{~W} /(\mathrm{m} \cdot \mathrm{K})$ praèjus 1 dienai po gamybos, o gniuždymo stipris padidejo nuo $175 \mathrm{kPa}$ iki $250 \mathrm{kPa}$. Matmenų stabilumas blogejo didinant palmių aliejaus poliolio kiekị, tačiau neviršijo leistinujų nuokrypų, nurodomų gaminio standarte.

Zieleniewska et al. 2015 analizavo galimybę tradicinį naftos produktų poliolị pakeisti polioliu iš rapsų aliejaus. Paaiškejjo, kad, didinant ekologiško poliolio kiekị nuo $0 \%$ iki $100 \%$, esant beveik tam pačiam poliuretano putų tankiui, gniuždymo stipris sumažejo nuo $760 \mathrm{kPa}$ iki $680 \mathrm{kPa}$. Atlikti termogravimetrinès analizès tyrimai parodè, kad poliolio iš rapsų aliejaus panaudojimas padidina galutinio gaminio termini ir lakiųjų junginių išsiskyrimo atsparumus bei $\sim 45 \%$ sumažina vandens sugertị visiškai jame panardinus 24 val.

Tu et al. $200750 \%$ tradicinio poliolio mègino pakeisti polioliu iš sojų aliejaus. Rezultatai parodè, kad dauguma sojų aliejaus pagrindu pagamintų poliuretano putų pasižymèjo tokiu pačiu šilumos laidumo koeficientu, kaip poliuretano putos, kurių gamyboje naudotas naftos produktų poliolis, tačiau beveik dvigubai 
pablogino gniuždymo stiprį. Tuo tarpu autoriai Zlatanić et al. 2015 tradicinị poliolị sèkmingai pakeitè $65 \%$ polioliu iš sojų aliejaus. Gautos poliuretano putos pasižymèjo nuo $92 \%$ iki $98 \%$ atvirapore struktūra, panašiu ị kontrolinių putų tankiu, tačiau nuo $26 \%$ iki 68 \% mažesniu tempimo stipriu. Naujausi tyrimai (Kurańska, Prociak 2016) parodè, kad, tradicinị poliolị keičiant 70 \% polioliu iš rapsų aliejaus, poliuretano putų mišinio reaktyvumas sulètèjo, tankis sumažejo nuo $36 \mathrm{~kg} / \mathrm{m}^{3}$ iki $33 \mathrm{~kg} / \mathrm{m}^{3}$, o uždarų akučių kiekis - nuo $95 \%$ iki $87 \%$, lyginant su kontrolinèmis poliuretano putomis.

Jungtinèse Amerikos Valstijose citrusinių vaisių pramonè išgauna bioatlieką, kurios sudètyje yra daug limoneno. Mokslininkai Gupta et al. 2015 sugalvojo šią atlieką panaudoti polioliu gamyboje. Skirtingai nei dauguma biopoliolių, limoneno poliolis pasižymèjo pakankamai dideliu hidroksilų skaičiumi - $452 \mathrm{mg} \mathrm{KOH} / \mathrm{g}$, tačiau labai didele klampa - $22 \mathrm{~Pa} \cdot \mathrm{s}$. Poliuretano putų, kuriose panaudota $50 \%$ šio poliolio, mechaninès, terminès ir fizikinès savybès yra panašios i tų poliuretano putų, kuriose panaudotas tradicinis poliolis (Gupta et al. 2014).

\subsection{Poliuretano putu gamyboje naudojami izocianatai ir jụ struktūra, poveikis gaminių fizikinèms ir mechaninèms savybèms}

Izocianato pasirinkimas poliuretano putų gamyboje priklauso nuo galutinio gaminio panaudojimo srities. Molekulinè forma, funkcionalumas ir reaktyvumas lemia poliuretano gaminių savybes. Aromatiniai izocianatai, lyginant su alifatiniais, yra reaktyvesni ir ekonomiškesni.

Du pagrindiniai aromatiniai izocianatai, naudojami poliuretano putu gamyboje, yra tolueno diizocianatas (TDI) ir metileno difenilo diizocianatas (MDI). TDI dažniausiai yra 2,4- ir 2,6- (1.6 pav. a ir b) izomerų mišinys. MDI turi tris izomerus: 4,4'-; 2,4'-; 2,2'- (Zain et al. 2014) (1.6 pav. c, d ir e). 4,4'- izomeras, kuris yra mažiau lakus nei kiti du likę MDI izomerai, dažniausiai naudojamas standžiųjų poliuretano putų gamyboje. MDI kietintas galutinis poliuretano gaminys, kitaip nei TDI, kuris naudojamas lanksčiujų poliuretano putų gamyboje, pasižymi didesniu gniuždymo stipriu. Šiuo metu standžiųu poliuretano putų gamyboje naudojamas izocianatas yra polimerinis MDI (pMDI) (1.6 pav.f). Jis pasižymi maža klampa ir didesniu funkcionalumu.

Izocianato kiekis, reikalingas reakcijai su polioliu ar kitais reaguojančiais komponentais, apskaičiuojamas atsižvelgiant ị stechiometrinius ekvivalentus. Teorinis stechiometrinis izocianato kiekis gali būti didinamas arba mažinamas, priklausomai nuo galutinio gaminio panaudojimo srities ir norimų savybių. 

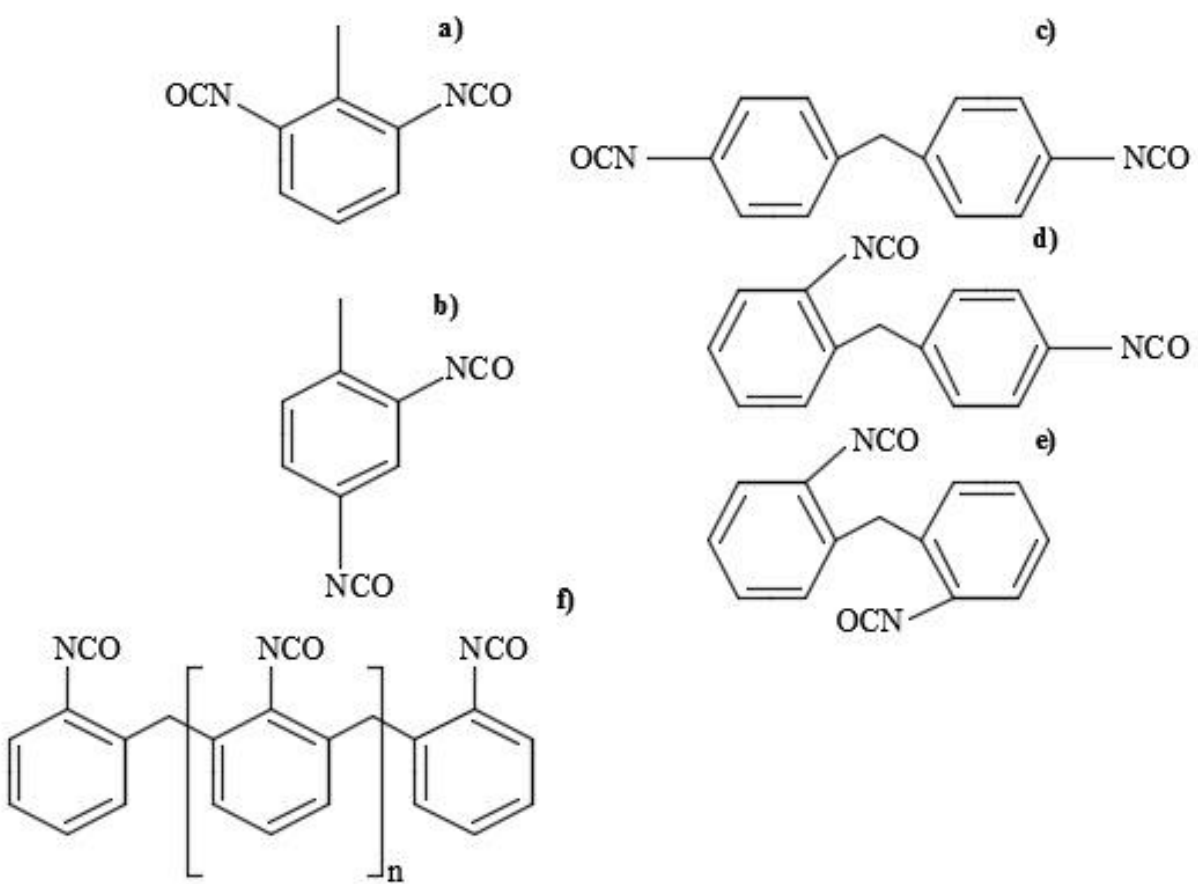

f)

1.6 pav. Poliuretano putu gamyboje naudojami izocianatai: a) 2,6- TDI; b) 2,4- TDI; c) 4,4'- MDI; d) 2,4'- MDI; e) 2,2'- MDI; f) pMDI

Fig. 1.6. Isocyanates used for the production of polyurethane foam: a) 2,6- TDI; b) 2,4- TDI; c) 4,4'- MDI; d) 2,4'- MDI; e) 2,2'- MDI; f) pMDI

Vienas iš svarbiausių parametrų sudèties skaičiavime yra izocianato indeksas. Standžiųu poliuretano putų gamyboje naudojamas $100 \div 150$ indeksas, o poliizocianurato $-150 \div 300$. Izocianato indeksas yra vienas tų parametrų, lemiančių pagrindines poliuretano putų savybes, kurio poveikị nagrinèjo nemažai mokslininkų. Autorių Kim, Kim 2008 tyrimai parodè, kad poliuretano putų, išpūstų aplinkai nekenksmingu dujodariu HFC 365mfc, tankis ir šilumos laidumo koeficientas mažèja dèl padidejusio mišinio slankumo, kuriam poveikị daro nuo 90 iki 130 didèjantis izocianato indeksas, ir papildomo pūtimosi, kurị sukelia $\mathrm{CO}_{2}$ dujos, atsirandančios dèl kondensacijos reakcijų tarp izocianato grupių. Panašia tendencija pasižymèjo ir gniuždymo stiprio nustatymo rezultatai.

Analogiškus rezultatus gavo autoriai Park et al. 2013, kurie tyrè izocianato indekso ir skirtingų, aplinkai nekenksmingų, dujodarių poveiki poliuretano - poliizocianurato putų savybėms. Vandeniu išpūsti gaminiai pasižymèjo nuo $0,0224 \mathrm{~W} /(\mathrm{m} \cdot \mathrm{K})$ iki $0,0221 \mathrm{~W} /(\mathrm{m} \cdot \mathrm{K})$, vandens ir ciklopentano mišiniu-nuo 
$0,0213 \mathrm{~W} /(\mathrm{m} \cdot \mathrm{K})$ iki $0,0211 \mathrm{~W} /(\mathrm{m} \cdot \mathrm{K})$ ir ciklopentanu - nuo $0,0201 \mathrm{~W} /(\mathrm{m} \cdot \mathrm{K})$ iki $0,0195 \mathrm{~W} /(\mathrm{m} \cdot \mathrm{K})$ mažèjančiu šilumos laidumo koeficientu, kuomet izocianato indeksas kito nuo 150 iki 300. Šiu autorių gauti rezultatai parodè, kad poliuretano putų gniuždymo stipris didejja, didèjant izocianato indeksui nuo 150 iki 200, tačiau, naudojant dar didesnị izocianato kiekị, gaunami poliizocianurato gaminiai pasižymi trapumu ir mažesniu tankiu. Termogravimetrinė analizė parodé, kad vandeniu išpūstos poliizocianurato-poliuretano putos yra termiškai stabilesnès nei tos, kurios buvo išpūstos ciklopentanu. Tai aiškinama tuo, kad vandeniu išpūstose putose formuojasi urejja grupès, kurios yra termiškai stabilesnès nei uretano grupès. Autoriai Kurańska, Prociak 2015 nurodè, kad poliizocianurato-poliuretano putų terminis irimas yra sudètingas procesas ir vyksta tokia tvarka: izocianurato $\left(350{ }^{\circ} \mathrm{C}\right)>\operatorname{ureja}\left(250^{\circ} \mathrm{C}\right)>\operatorname{uretano}\left(200^{\circ} \mathrm{C}\right)>$ biureto (nuo $135^{\circ} \mathrm{C}$ iki $140{ }^{\circ} \mathrm{C}$ ) $>$ alofanato (nuo $106^{\circ} \mathrm{C}$ iki $125^{\circ} \mathrm{C}$ ).

Stirna et al. 2006 teigia, kad poliuretano putų gaminiai, kuriuose naudotas izocianato indeksas yra lygus 125, pasižymi termoizoliacinei medžiagai netinkamomis savybėmis, t. y. didele pradine susitrauktimi ir $50 \%$ mažesniu procentiniu uždarų akučių kiekiu. Taip pat pastebèta, kad putos, kuriose izocianato indeksas yra > 250, pasižymi netinkama adhezija kitų paviršių atžvilgiu arba jos nebuvimu bei didele vandens sugertimi, kurios dydị, didèjant izocianato indeksui, lemia nepakankamai didelis izocianato grupių transformacijos laipsnis, todèl nesureagavusios izocianato grupès veikia kaip vandens sugèrikliai, kurie didina galutinio gaminio hidrofiliškumą. Tolimesni tyrimai (Guo et al. 2000) parodè, kad gniuždymo stipris proporcingai dideja, didejjant izocianato indeksui nuo 110 iki 130. Šie mokslininkai teigia, kad izocianato perteklius lemia standesnę galutinio gaminio struktūrą dèl visiškos hidroksilų grupių poliolyje reakcijos su izocianatu. Taip pat pastebèta, kad sumažinus izocianato indeksą iki 60, sumažèja galutinio gaminio tankis bei mechaninès savybès (Tu et al. 2009).

\subsection{Tradiciniai dujodariai ir jų alternatyvos}

Halogeninti angliavandeniliai yra grupè junginių, susidedančių iš anglies ir bent vieno angliavandenilio (fluorino, chlorino, jodino ar bromino). Pagal 1.7 paveikslą dujodarių pasirinkimas yra ịvairus techninių parametrų ir ekonominių rodiklių atžvilgiu. Šios medžiagos pirmą kartą susintetintos 1928 metais ir nuo tada yra naudojamos ịvairiose pramonès srityse (lanksčiujų ir standžiųu putų gamyboje - kaip šaltnešis, oro vẻdinimo sistemose - kaip tirpikliai ar medžiagos, skirtos valymui). Šioms medžiagoms priskiriami anglies fluoridai (CFC), chlorinti ir fluorinti angliavandeniliai (HCFC) ir fluorinti angliavandeniliai (HFC). Kuo didesnis chloro kiekis junginyje, tuo ilgiau jis sąveikaus su ozono molekulėmis. 
CFC turi daugiau chloro nei HCFC, todèl ši medžiaga pasižymi didesniu ODP (Bolaji, Huan 2013).

Kita svarbi aplinkosaugos problema - globalinis atšilimas. Kai kurių fluorintų šiltnamio efektą sukeliančių dujų gyvavimo trukmė atmosferoje gali siekti kelis tūkstančius metų, todèl svarbu ịvertinti GWP vertę, kuria visos dujos lyginamos su $\mathrm{CO}_{2}$ dujomis, kurių GWP yra lygus 1 .

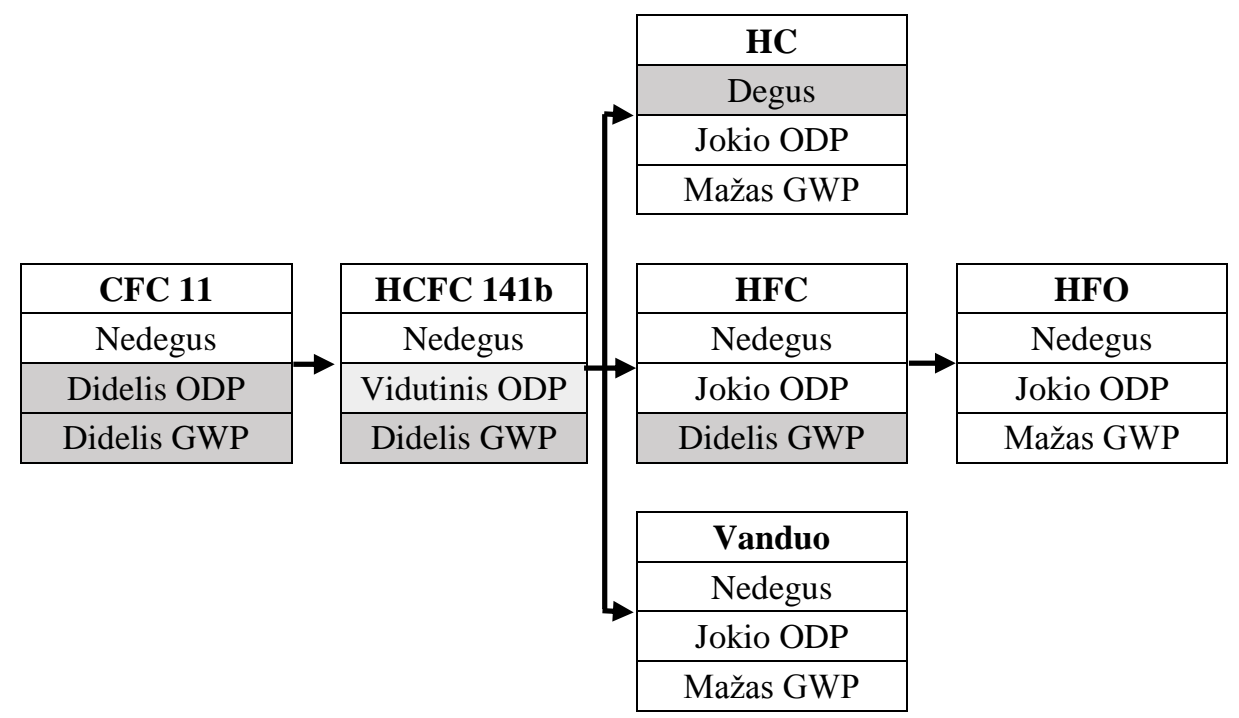

1.7 pav. Poliuretano putų gamyboje naudojamų dujodarių klasifikaciniai požymiai

(Wallington et al. 2015)

Fig. 1.7. Classification indicators for blowing agents used in the production of polyurethane foam (Wallington et al. 2015)

1987 m. buvo pasirašytas Monrealio protokolas dèl daugumos medžiagų, prisidedančių prie ozono sluoksnio ardymo, pakeitimo ir gamybos nutraukimo. Pramonès šalyse, pavyzdžiui, Junginėse Amerikos Valstijose, CFC nebenaudojamas jau nuo 1996 m. ir tik neseniai pradètas drausti besivystančiose šalyse. Tokiuose regionuose, kaip Europos Sajunga ir Jungtinès Amerikos Valstijos, HCFC 141b yra uždraustas daugiau kaip dešimtmetį. 1.2 lentelèje nurodytos alternatyvių HCFC 141b medžiagai dujodarių savybės. Besivystančiose šalyse $2013 \mathrm{~m}$. sausio $1 \mathrm{~d}$. HCFC $141 \mathrm{~b}$ naudojimas buvo apribotas ir nuo $2014 \mathrm{~m}$. sausio $1 \mathrm{~d}$. palaipsniui mažinamas, o iki $2030 \mathrm{~m}$. bus visiškai uždraustas.

Šiuo metu nèra tokių dujodarių, kurie visapusiškai galètų pakeisti HCFC 141 b naudojimo paprastumo, savybių bei transportavimo atžvilgiu. Pastaraji dešimtmetị alternatyvų paieška vyksta visose išsivysčiusiose šalyse. Kijoto protokolas (UN 1998; Anderse et al. 2014; Tuckett 2016) numatė HFC emisijos 
kontrolę dèl didelio GWP, todèl buvo pradèti kurti dvigubas jungtis turintys halogeninti fluorinti angliavandeniliai olefinų pagrindu (HFO) (Wallington et al. 2015). Šis dujodaris pasižymi mažu GWP dèl staigios reakcijos su atmosferoje esančiais OH radikalais (WMO 2011), tačiau tokios medžiagos naudojimas pramonèje bus pradètas tik po kelerių metų, todèl šiuo metu $\mathrm{CO}_{2}$ dujos yra pripažintos kaip labiau aplinką tausojantis ir mažiau klimatui kenksmingas cheminis dujodaris (Wada, Fukuda 2009; Lan et al. 2014; Sonnenschein, Wendt 2013), nes jo ODP yra lygus vienam, o GWP - labai mažas.

1.2 lentelè. Alternatyvių dujodarių savybių lyginimas su HCFC 141b (Wallington et al. 2015)

Table 1.2. Comparison of properties of alternative blowing agents and HCFC $141 \mathrm{~b}$ (Wallington et al. 2015)

\begin{tabular}{|l|c|c|c|}
\hline \multicolumn{1}{|c|}{ Rodiklis } & Pentanas & $\begin{array}{c}\text { HFC 245fa } \\
\text { HFC 365mfc/227ea }\end{array}$ & Vanduo \\
\hline $\begin{array}{l}\text { Gaminio šilumos } \\
\text { laidumo koefi- } \\
\text { cientas* }\end{array}$ & $5-10 \%$ didesnis & $5-10 \%$ didesnis & $20-40 \%$ didesnis \\
\hline Gaminio tankis* & $5 \%$ mažesnis & Panašus & $5-10 \%$ didesnis \\
\hline Speciali ịranga & $\begin{array}{l}\text { Reikalinga sprogi- } \\
\text { mui atspari ịranga }\end{array}$ & - & - \\
\hline GWP & 11 & Nuo 794 iki 3220 & 1 \\
\hline
\end{tabular}

$\left.{ }^{*}\right)$ Lyginama su HCFC 141b išpūstų poliuretano putų savybėmis, kuomet dujodario kiekis žaliavų mišinyje yra vienodas.

Kalbant apie poveiki aplinkai, ši medžiaga patenka $\mathfrak{i}$ atmosferą iškastinio kuro (anglies, gamtinių dujų ir naftos), kietujų atliekų, medienos ir jos gaminių deginimo metu bei cheminių reakcijų metu (gaminant cementą). Vykstant šiems procesams, išskiriamų $\mathrm{CO}_{2}$ dujų kiekiai yra milžiniški. Kita vertus, poliuretano gamybos metu išsiskiriančių $\mathrm{CO}_{2}$ dujų kiekis yra labai mažas ir, lyginant su tradiciniais dujodriais, ODP ir GWP yra nuo kelių iki kelių šimtų kartų mažesnis (Nunez et al. 2010), tačiau, šios medžiagos laikymui ir maišymui kartu su poliuretano žaliavomis reikalinga itin sudettinga įranga (Grolier, Randzio 2012; Kim, Youn 2000; Fieback et al. 2011; Dai et al. 2013; Log et al. 2014). Dèl šios priežasties imta ieškoti kitų, pigesnių ir patrauklesnių alternatyvų. Viena iš jų - vanduo, tačiau galutinis poliuretano gaminys pasižymi prastesne nei tradiciniais dujodariais išpūstų gaminių paviršiaus kokybe bei adhezija kitų paviršių atžvilgiu, taip pat dideliu tankiu, apie 20-40 \% didesniu šilumos laidumo koeficientu ir per didele pradine susitrauktimi bei netinkamu matmenų stabilumu. Kita vertus Thirumal et al. 2008 gauti rezultatai rodo, kad, didinant vandens kiekį žaliavų mišinyje, galima gauti mažo tankio poliuretano gaminị. Panaudojus nuo 0 iki 3 dalių pagal mišinio masę (dpm) vandens, tankis sumažèjo nuo $116 \mathrm{~kg} / \mathrm{m}^{3} \mathrm{iki} 42 \mathrm{~kg} / \mathrm{m}^{3}$, 
akučių skersmuo padidèjo nuo $233 \mu \mathrm{m}$ iki $488 \mu \mathrm{m}$, šilumos laidumo koeficientas - nuo $0,022 \mathrm{~W} /(\mathrm{m} \cdot \mathrm{K})$ iki $0,027 \mathrm{~W} /(\mathrm{m} \cdot \mathrm{K})$, o vandens sugertis visiškai jame panardinus - nuo $0,6 \%$ iki $6,8 \%$. Panašiais rezultatais pasižymejjo mokslininkų Seo et al. 2003 pagamintos standžiosios poliuretano putos. Tuo tarpu autorių Fan et al. 2012 nuo 2,0 dpm, iki 4,0 dpm vandeniu išpūstų poliuretano putų tankis sumažèjo nuo $68 \mathrm{~kg} / \mathrm{m}^{3}$ iki $39 \mathrm{~kg} / \mathrm{m}^{3}$, o šilumos laidumo koeficientas padidejjo nuo $0,0271 \mathrm{~W} /(\mathrm{m} \cdot \mathrm{K})$ iki $0,0295 \mathrm{~W} /(\mathrm{m} \cdot \mathrm{K})$.

\subsection{Katalizatoriai ir jų poveikis poliuretano mišinių reakcijos kinetikai}

Katalizatoriai naudojami polimero tinklo formavimo (poliolio ir izocianato reakcija - (1.1) formulè) ir išpūtimo (vandens ir izocianato reakcija - (1.2) formulè) reakcijų kontrolei.

$$
\begin{aligned}
\mathrm{O}=\mathrm{C}= & \mathrm{N}-\mathrm{R}_{\text {(izocianatas) }}-\mathrm{N}=\mathrm{C}=\mathrm{O}+\mathrm{HO}-\mathrm{R}_{\text {(poliolis) }}-\mathrm{OH} \rightarrow \\
\mathrm{O}=\mathrm{C}= & \mathrm{N}-\mathrm{R}_{\text {(izocianatas) }}-\mathrm{NH}-\mathrm{C}(\mathrm{O})-\mathrm{O}-\mathrm{R}_{\text {(poliolis) }}-\mathrm{O}- \\
& \mathrm{C}(\mathrm{O})-\mathrm{NH}-\mathrm{R}_{\text {(izocianatas) }}-\mathrm{N}=\mathrm{C}=\mathrm{O} \\
\mathrm{O}= & \mathrm{C}=\mathrm{N}-\mathrm{R}_{\text {(izocianatas) }}-\mathrm{N}=\mathrm{C}=\mathrm{O}+2 \mathrm{H}_{2} \mathrm{O} \rightarrow \\
& \mathrm{H}_{2} \mathrm{~N}-\mathrm{R}_{\text {(izocianatas) }}-\mathrm{NH}_{2}+\mathrm{CO}_{2 \text { (dujos). }}
\end{aligned}
$$

Prasidejjus išpūtimo reakcijai (1.2), išsiskiria $\mathrm{CO}_{2}$ dujos, kurios išpučia maišymo metu susidariusius oro burbuliukus. Prasidejjus standẻjimo reakcijai (1.1), padidèja mišinio klampa, kuri suvaržo putų pūtimąsi.

Plačiausiai naudojami katalizatoriai yra tretiniai aminai ir organinių metalų junginiai (dažniausiai alavo junginiai). Šių medžiagų veikimo principas pagrịstas trumpalaikių kompleksų tarp katalizatoriaus ir izocianato formavimusi. Tretiniai aminai gali skatinti tiek pūtimosi, tiek standèjimo reakcijas, tačiau priklauso pūtimąsi skatinančių katalizatorių grupei (Randall, Lee 2010). Organinių metalų junginių katalizatoriai yra reaktyvesni už aminų katalizatorius, todèl naudojami itin mažais kiekiais ir yra priskiriami standëjimą skatinančių katalizatorių grupei.

Poliuretano putų išpūtimo ir standejimo reakcijų greitis priklauso nuo daugelio faktorių, pavyzdžiui, reakcijos temperatūros, katalizatoriaus tipo bei kiekio (Sipaut et al. 2010). Užtikrinus pusiausvyrą tarp minètųų reakcijų, gaunami gaminiai pasižymi tolygia struktūra, mažesniu tankiu bei geresnemis mechaninèmis savybèmis (Singh et al. 2007). Campanella et al. 2009 tyré N,N- dimetilbenzilamino poveiki poliuretano putoms. Gauti rezultatai parodè, kad putose, kuriose nebuvo panaudotas katalizatorius, dominavo išpūtimo reakcija. Tai lèmė priešlaikinị 
putų suirimą. Taip pat išsiaiškinta, jog strutūroje esančios akutės nežymiai mažèja, didinant katalizatoriaus kiekị, tai leidžia manyti, jog katalizatoriai lemia poliuretano putų pūtimosi kinetiką (Choe et al. 2004).

\subsection{Paviršių aktyvinančios medžiagos. Racionalaus kiekio parinkimas}

Paviršių aktyvinanti medžiaga (PAM) yra viena iš pagrindinių medžiagų, kontroliuojančių struktūros susidarymą ir akučių dydị poliuretano putų gamyboje. Šios medžiagos sulaiko dujų burbuliukus, susidarančius užuomazgų formavimosi metu, ir apsaugo juos nuo suirimo. Viena iš tokių medžiagų yra silikoninè paviršių aktyvinanti medžiaga - skiepytas kopolimeras iš polisiloksano su polieterio šonine grandimi. Autorių Zhang et al. 1999 gauti rezultatai parodè, kad kuo didesnis silikono ir poliesterio kiekių santykis, tuo mažesnis paviršiaus ịtempimas, sąlygojantis mažesnèmis akutėmis pasižyminčios struktūros formavimąsi. Taip pat išsiaiškinta, kad, didinant PAM kieki nuo 0 dpm iki 0,33 dpm, tankis nesikeičia, tačiau struktūra pasižymi taisyklingesnèmis ir perpus mažesnèmis akutėmis, tai lèmé mažesnị šilumos laidumo koeficientą ir didesnius lenkimo, tempimo ir gniuždymo stiprius (Seo et al. 2003). Tolimesni tyrimai (Han et al. 2009) parodè, kad polisiloksano eterių aktyvumas ir rezultatyvumas priklauso nuo silikono ir poliesterio kiekių santykio, o optimalus PAM kiekis, atsižvelgiant ị šilumos laidumo koeficiento vertes, strukturą bei stiprumines savybes, yra 2,0 dpm (Lim et al. 2008) ir didesnis šios medžiagos kiekio naudojimas nèra racionalus.

\subsection{Poliuretano putų struktūros modifikavimas grandinès plètikliais}

Poliuretano putos yra segmentinis blokinis kopolimeras, todèl jas sudaro kietieji ir minkštieji segmentai (1.8 pav.). Kietieji segmentai gali būti tiek aromatiniai, tiek alifatiniai. Aromatiniai formuojasi naudojant MDI, o alifatiniai H12 MDI. Kuomet šie izocianatai sumaišomi su trumpagrandžiais dioliais, jie tampa kietaisiais segmentais. Kita vertus, minkštieji segmentai gali būti tiek polieteriniai, tiek poliesteriniai, kurie formuojasi izocianatui reaguojant, atitinkamai, su polieteriniu ar poliesteriniu didelès molekulinès masès polioliu.

Siekiant pakeisti poliolius iš naftos produktų, polioliai iš augalinès kilmès aliejų standžiųu poliuretano putų gamyboje privalo tenkinti tam tikrus reikalavimus, t. y. turèti atitinkamą funkcionalumą $(>3)$, molekulinę masę $(<1200 \mathrm{~g} / \mathrm{mol})$ ir hidroksilų skaičių, kuris svyruoja nuo $350 \mathrm{mg} \mathrm{KOH/g} \mathrm{iki} 600 \mathrm{mg} \mathrm{KOH/g}$ 
(Pawar et al. 2016). Šių poliolio savybių modifikavimui gali būti naudojami difukciniai, trifunkciniai ar daugiafunkciai mažos molekulinès masès grandinès plètikliai.

a)
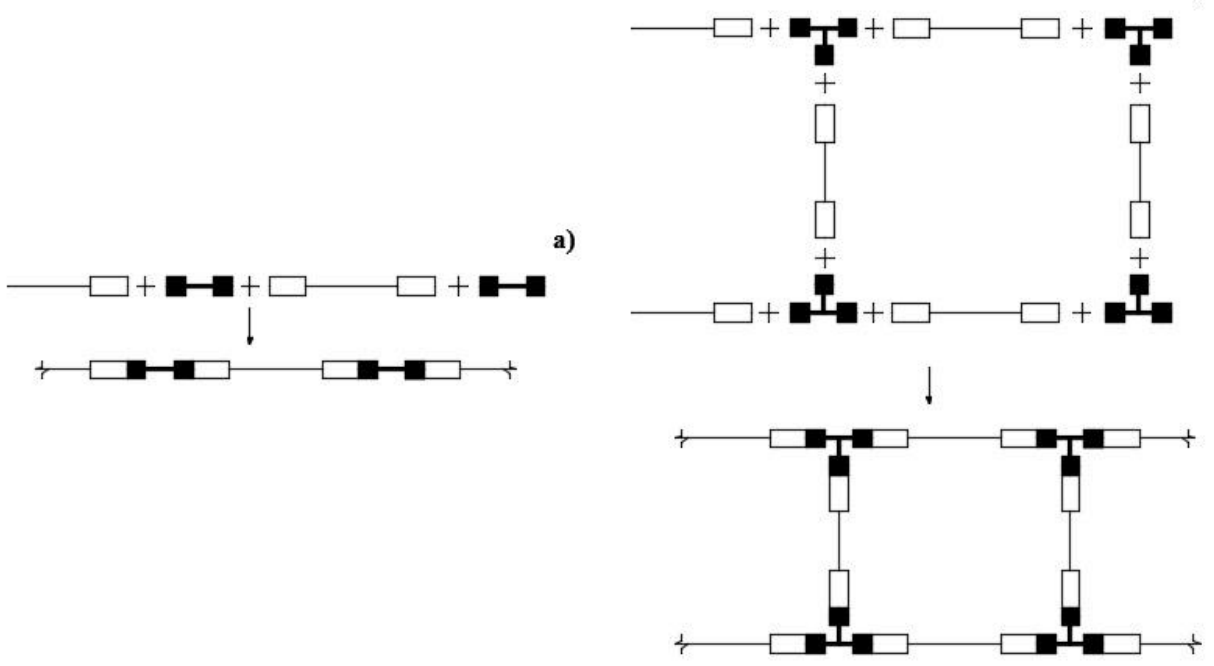

1.8 pav. Grafinè a) grandinès plètiklių ir b) skersines grandis sudarančių medžiagų reakcijų su minkštaisiais segmentais interpretacija (Li, Ryan 2002): $\square-$ minkštieji segmentai; - - kietieji segmentai

Fig. 1.8. Graphical interpretation of reactions between a) chain extenders and b) cross - linkers and soft segments (Li, Ryan 2002): $\square-$ soft segments; - - hard segments

Difunkcinès medžiagos (1.8 pav. a) formuodamos tiesinę ir ištęstą struktūrą yra vadinamos gradinès plètikliais. Šios medžiagos yra naudojamos poliuretano mišiniuose gaminių kietejjimo spartinimui. Trifunkciniai ir daugiafunkciai grandinès plètikliai (1.8 pav. b) yra medžiagos, kurios formuoja skersinius ryšius ir yra vadinamos skersinius ryšius sudarančiomis medžiagomis, kurios naudojamos galutinio gaminio fizikinių ir mechaninių savybių gerinimui. Autorius Firdaus 2011 poliuretano putų iš sojų aliejaus poliolio savybių modifikavimui naudojo difunkcinị etilenglikolị ir tyrè jo poveikị galutinio gaminio tankiui bei vandens sugerčiai. Tyrimai parodè, kad grandinès plètiklio panaudojimas lèmé lanksčiujų arba pusiau standžiưjų poliuretano putų formavimąsi. Didèjant etilenglikolio kiekiui, poliuretano putų tankis didejjo dèl kietujų segmentų formavimosi galutinio gaminio struktūroje. Tokias pačias tendencijas pastebejo ir Pratondo et al. 2012. 
Mokslininkai Li, Ryan 2002 tyrè dietanolamino, etilenglikolio, glicerino bei 2-metilamino etanolio poveikị poliuretano putų struktūrai ir išsiaiškino, kad grandinès plètikliai, nusėsdami kietuosiuose segmentuose, pakeičia jų struktūrą ir vandenilio jungimosi tvarką. Tokie pasikeitimai struktūroje sumažina kietuosiuose segmentuose esančių vidinių segmentų sukibimą ir padidina minkštųų ir kietujų segmentinių blokų suderinamumą.

Autoriai Tu et al. 2007 paruošè 50 poliolių iš augalinès kilmès aliejų ir jais keite $50 \%$ tradicinị poliolị iš naftos produktų. Jie išsiaiškino, kad galutiniai standžiųju poliuretano putų gaminiai pasižymejjo prastesnèmis savybėmis nei poliuretano putos iš $100 \%$ naftos produktų poliolio, todèl Tan et al. 2011 nusprendè ištirti dietilenglikolio ir glicerino poveiki standžiosioms poliuretano putoms. Nuo $25 \%$ iki $50 \%$ tradicinis poliolis buvo keičiamas sojų aliejaus polioliu, pridedant $6 \%$ pagal masę dietilenglikolio ir $16 \%$ pagal masę glicerino.

Biologiškai skaidžių medžiagų gamybai naudojamas polietilenglikolis yra sudarytas iš minkštuju segmentų, kurie pasižymi dideliu hidrofiliškumu. Tyrimai (Yang et al. 2007) šia tema vyko, norint padidinti poliuretano putų vandens sugertị. Šiam tikslui naudoti algininè rūgštis, polietilenglikolis bei glicerinas. Paaiškejo, kad vandens sugertis beveik 1,5 karto padidejo, panaudojus $20 \%$ algininès rūgšties. Ši reiškinị mokslininkai paaiškino tuo, kad šioje medžiagoje yra daug hidrofilinių $-\mathrm{OH}$ ir $-\mathrm{COO}^{-}$grupių, tačiau tokių poliolių pagrindu pagamintos poliuretano putos pasižymi mažu stiprumu (Oh et al. 2011), todèl šios problemos šalinimui mokslininkai Lee et al. 2014 naudojo polietilenglikolị, polilaktinę rūgštị bei gliceriną. Jeigu poliuretano putų gamyboje naudojamas ganètinai mažas izocianato indeksas arba, jei dujodariu pasirinktas vanduo, poliuretano putos pasižymés pradine susitrauktimi. Mokslininkai Kwon et al. 2007 šios problemos šalinimui naudojo gliceriną. Paaiškejjo, kad jis veikia kaip trifunkcinè skersinius ryšius sudaranti medžiaga, kuri padidina kietųų segmentų kiekị ir neleidžia putoms susitraukti. Mokslininkai Lin et al. 1997 lanksčiųų poliuretano putų savybių modifikavimui panaudojo biomasę, t. y. sojų plaušus, sojų baltymų izoliatą ir kukurūzų krakmolą. Grandinių plètikliais pasirinktos medžiagos pasižymèjo hidroksilų grupèmis, kurios, reaguodamos su izocianatu, formuoja kietaji arba minkštaji poliuretano putų karkasą. Buvo pastebèta tankio didejjimo tendencija, tačiau gniuždymo stipris šiuo atveju neturejo priklausomybès nuo tankio ir mažejo, didèjant grandinès plètiklių kiekiams nuo $10 \%$ iki $40 \%$. Autoriai Rashmi et al. 2013 iš kukurūzų susintetino 1,3-propandiolị, kurị panaudojo kaip poliuretano putų grandinès plètiklį. Ši medžiaga pasižymèjo tokiomis pat savybèmis, kaip ir 1,3-propandiolis iš naftos produktų, t. y. maža molekuline mase $(76 \mathrm{~g} / \mathrm{mol})$ bei funkcionalumu, lygiu 2. Poliuretano putos turèjo vienodą kietụjų segmentų skaičių, panašų terminị stabilumą bei tempimo stiprị. Toliau šis grandinès plètiklis buvo naudojamas poliuretao putų su mikrokristaline celiulioze kūrimui ir tyrimams 
(Głowińska, Datta 2015; Głowińska, Datta 2016). Tęsdami pradètus tyrimus ekologiškų cheminių medžiagų kūrime, autoriai Datta, Głowińska 2014 iš glicerino susintetino 1,2-propandioli (propilenglikolị) ir panaudojo ji bei 1,3-propandioli standžiųjų poliuretano putų gamybai.

Gauti rezultatai parodè, kad šie grandinès plètikliai modifikuoja gaminių cheminę struktūrą bei savybes, kurios priklauso nuo panaudoto grandinès plètiklio hidroksilų grupių tipo (pirminès ar antrinès).

\subsection{Popieriaus gamybos atliekų dumblas}

Taršos prevencija popieriaus gamybos pramonèje yra pagrindinė pasaulinė siekiamybė (EC 2013; DW 2008). Vienas iš pagrindinių Europos komisijų ir direktyvų tikslų yra paversti ES šalis „perdirbančia visuomene“ (Arena 2015; Rada et al. 2014; DEPC 2006), kuri yra pajègi sumažinti atliekų kaupimąsi ir panaudoti jas skirtinguose procesuose (Rivera et al. 2016).

PGAD yra pagrindinis ir didžiausias šalutinis produktas popieriaus gamybos procese (apie $35 \%$ nuo pagaminamo popieriaus (Frías et al. 2015), o jo šalinimas bei naikinimas yra pagrindinè aplinkosaugos problema (Bajpai 2015).

\subsubsection{Popieriaus gamybos atliekų dumblo susidarymas}

Ivairios kietosios atliekos ir dumblas susidaro skirtinguose minkštosios masès ir popieriaus gamybos pramonių technologinių procesų etapuose. Pagrindinis šių atliekų susidarymo šaltinis yra atliekinio vandens perdirbimas. Kietosios atliekos ir dumblas, susidarantys popieriaus gamyboje, gali būti skirstomi ị:

1. Perdirbto popieriaus atliekas.

Perdirbto popieriaus atliekas sudaro priemaišos, t. y. plaušeliu sankaupos, sankabėlès ir metalo gabaliukai, smèlis, stiklas, plastikas ir popieriaus užpildo likučiai, klijavimui skirtos medžiagos ir kiti chemikalai. Jos pasižymi santykinai maža drègme, yra lengvai sausinamos ir dažniausiai deginamos arba laikomos sąvartynuose. Šioms atliekoms taip pat priskiriamos filtrų atliekos, kurios susidaro minkštosios masès filtravimo etape, kuomet šalinamos celiuliozės plaušelių sankaupos, trukdančios gamybą ir bloginančios gaminio kokybę.

2. Rašalo šalinimo atliekas.

Šios atliekos susideda iš trumpų plaušelių ar dalelių, dangai skirtų medžiagų, užpildų, rašalo dalelių (sunkiụjų metalų šaltinis) ir rašalo šalinimui skirtų priedų. Rašalo ir plaušeliu atskyrimui naudojamas flotacijos metodas, kai susidariusios putos surenkamos flotacinio įrenginio kameros paviršiuje. Susidariusị rašalo šalinimo dumblą sudaro rašalas, kietosios neorganinių medžiagų dalelès ir trumpi celiuliozès plaušeliai. 
3. Pirminị dumblą.

Ši dumblą sudaro smulkios dalelès ir užpildai, kurių sudètis priklauso nuo perdirbamo popieriaus. Pirminị dumblą galima pakartotinai naudoti kartono gamyboje.

4. Antrinį dumblą.

Šis dumblas susidaro atliekinio vandens valymo ịrenginiuose ir jis gali būti perdirbamas ị kartono gaminius arba suspaudžiamas, sausinamas ir deginamas arba sandèliuojamas sąvartynuose. Antrinio dumblo susidaro mažiau nei pirminio, kadangi didžioji dalis sunkiụų, plaušinių ir neorganinių kietujų dalelių pašalinama pirminio dumblo valymo metu.

Popieriaus gamybos atliekų dumblas, susidarantis atliekinio vandens valymo irenginiuose, t.y. antrinis dumblas (PGAD) pasižymi dideliu drégmès kiekiu $(\sim 50 \%)$, organine dalimi (mediena, ịvairiu ilgių celiuliozès plaušeliai, kurie per trumpi tolimesniam perdirbimui, ligninas ir tam tikrais atvejais organinis rišiklis $(\sim 25 \%)$ ir mineraline ikrova, kurią sudaro kalcio karbonatas, kaolinitas, talkas ir sunkieji metalai $(\sim 25 \%)$.

Šių atliekų cheminè sudètis bei fizikinès savybès skiriasi priklausomai nuo gaminamo popieriaus kokybès, atliekinio vandens valymo technologijos bei šviežio vandens sunaudojimo specifikos (Zule et al. 2007). Ivairių autoriu nustatyta cheminė PGAD sudètis pateikiama A priede. Šiuo metu PGAD laikomas sąvartynuose, tačiau, didejjant žmonijos poreikiams ir suvartojimui, didejja popieriaus gamybos mastai, o taip pat ir atliekų, kurios intensyviai mažina sąvartynuose vietą, kiekis. Atsižvelgiant ị teisès aktus dèl aplinkos taršos, didẻjančius mokesčius bei energijos suvartojimą atliekų deginimui, sąvartynai privalo būti naikinami. Todèl intensyviai ieškoma sričių, kuriose šias atliekas būtų galima panaudoti.

Galima pastebetti (A priedas), kad PGAD sudaro silicio, aliuminio ir kalcio oksidai. $\mathrm{SiO}_{2}$ ir $\mathrm{Al}_{2} \mathrm{O}_{3}$ yra pagrindiniai kaolinito, o $\mathrm{CaO}$ - kalcio karbonato komponentai. Pastebèta, kad gerai kontroliuojamo degimo metu molingosios medžiagos, esančios PGAD sudètyje - kaolinitas - gali būti transformuojamos i metakaolinitą. Degtos PGAD atliekos taip pat pasižymi dideliu pucolaniniu aktyvumu, kuris yra apibrèžiamas kaip medžiagos gebejjimas reaguoti su portlanditu, dalyvaujant papildomam vandens kiekiui (García et al. 2008), todèl tolimesnès PGAD panaudojimo galimybès buvo tirtos cemento bei keramikos gaminiu gamyboje (Lin et al. 2012; Martínez et al. 2012), taip pat ir žemès ūkyje (Gallardo et al. 2010; Gallardo et al. 2012), ceolitų sintezèje (Bao et al. 2016), sunkiụjų konstrukcijų (Cusidó et al. 2015, Haddar et al. 2016), vandeniui nelaidžių medžiagu (Wong et al. 2015), lengvujų konstrukcijų (Ferrándiz-Mas et al. 2014; Sutcu, Akkurt 2009) bei absorbentu gamyboje (Jin et al. 2015).

Autorius Bajpai 2015 pastebejjo, kad termiškai apdorotos PGAD dalelès yra labai poringos. Poringumas (atviros ar uždaros poros, porų dydis ir forma) turi itin didelị poveikị medžiagu šilumos laidumui, tačiau informacijos apie tiesioginị 
PGAD ar jo dalelių panaudojimą polimerinèse termoizoliacinėse medžiagose nèra.

\subsubsection{Popieriaus gamybos atlieku dumblo komponentu panaudojimo galimybès poliuretano putu gamyboje}

Polimerinių medžiagų su užpildais savybès labai priklauso nuo dalelių formos, dydžio ir šių dalelių pasiskirstymo. Yra penkios pagrindinès dalelių formos - sferos, kubo, dribsnio, plokštelès ir plaušo pavidalo. Naudojant plaušus, padidinamas poliuretano putų tempimo stipris, o plokštelių pavidalo daleles - standumas, kuris labiausiai priklauso nuo dalelių kraštinių santykių (Ahmed 2014).

Mokslininkai Sá e Sant'Anna et al. 2008 tyrè vieno iš pagrindinių PGAD komponentų $-\mathrm{CaCO}_{3}$ dalelių poveikị lanksčiosioms poliuretano putoms. Gauti rezultatai parodè, kad, didinant $100-250 \mu \mathrm{m}$ dydžio $\mathrm{CaCO}_{3}$ dalelių kiekị nuo $1 \%$ iki $30 \%$ pagal masę, mažèja tolygaus pasiskirstymo geba dèl pernelyg îvairaus dalelių dydžio, dalelès aglomeruojasi dèl netolygaus traukos jẻgu pasiskirstymo tarp užpildo ir polimerinès matricos. Taip pat nustatyta, kad per didelis $\mathrm{CaCO}_{3}$ kiekis didina histerezę ir pablogina galutinio gaminio kokybę. Autoriai Agarry et al. 2015 lanksčiųjų poliuretano putu gamybai kaip užpildą naudojo frakcionuotas $\mathrm{CaCO}_{3}$ daleles $(0,06 \mu \mathrm{m}, 0,5 \mu \mathrm{m}, 3,5 \mu \mathrm{m}, 10 \mu \mathrm{m}, 20 \mu \mathrm{m}$ ir $841 \mu \mathrm{m})$, kurių kiekis kito nuo $5 \%$ iki $40 \%$ pagal medžiagų masę. Nustatyta, kad, didinant užpildo kiekį, tempimo stipris $\sim 75 \%$ sumažejo nepriklausomai nuo dalelių dydžio. Per didelis užpildo kiekis lemia prastą dalelių pasiskirstymą ir aglomeratų formavimąsi, dèl to polimero matricoje atsiranda ịtempių koncentracija. Panašią lanksčiujjų poliuretano putų, modifikuotų $\mathrm{CaCO}_{3}$ užpildu, tempimo stiprio mažèjimo tendenciją pastebejo ir autoriai Usman et al. 2012. Jie taip pat nustatè, kad optimalus kalcio karbonato kiekis lanksčiosiose poliuretano putose yra $20 \%$ pagal masę, atsižvelgiant $\mathfrak{i}$ galutinio gaminio mechanines savybes ir pagaminimo kainą, kuri yra 1,2 kartų mažesnè nei poliuretano putų be $\mathrm{CaCO}_{3}$ užpildo. Autoriai Latinwo et al. 2010 pastebejjo, kad lanksčiosios poliuretano putos be $\mathrm{CaCO}_{3}$ užpildo pasižymėjo nevienodų ir didelių akučių struktūra, kurios formavimąsi lėmé homogeniškas užuomazgų susidarymas, kuriam reikalinga didesnė aktyvacijos energija. Naudojant užpildą, dalelès ir polimero matricos sąlyčio vietoje formuojasi dujos, dèl kurių putose susidaro mikroertmès, mažinančios aktyvacijos energiją, reikalingą poliuretano putų akučių formavimui.

Autoriai Zieleniewska et al. 2016 pastebejjo, kad kiaušinių lukštuose yra daug $\mathrm{CaCO}_{3}$, ir nusprendè šią medžiagą panaudoti kaip užpildą poliuretano putose. Dalelių dydis kito nuo $0,032 \mathrm{~mm}$ iki $2 \mathrm{~mm}$, o gauti gaminiai, užpildyti kiaušinių lukštų dalelèmis nuo $0 \%$ iki $25 \%$ (žingsniu $5 \%$ ), pasižymėjo gniuždymo stipriu, mažejjančiu nuo $450 \mathrm{kPa}$ iki $430 \mathrm{kPa}$, nuo 1,2 \% iki 1,5\% didejančia trumpalaike 
vandens sugertimi visiškai jame panardinus bei nekintančiu terminiu (irimo pradžios temperatūra $234{ }^{\circ} \mathrm{C}$, maksimumo temperatūra $386{ }^{\circ} \mathrm{C}$ ) ir matmenų stabilumais.

Kitas PGAD komponentas - kaolinitas. Mokslininkai Tawfik et al. 2013 tyré kaolinitu modifikuotų polimerinių medžiagu gniuždymo stiprị ir išsiaiškino, kad maksimali jo vertė pasiekiama, kuomet kaolinito naudojama 40 \% pagal masę. Didesnis šios medžiagos kiekis lèmè mechaninių savybių blogèjimą dèl sumažèjusio skersinių jungčių tankio, atsirandančio dèl per didelio atstumo tarp polimero grandžiu ir užpildo dalelių. Panašiais gniuždymo stiprio rezultatais pasižymėjo polimetilmetakrilatas ir poliuretanas, armuoti $0,5 \mu \mathrm{m}$ dydžio kaolinito dalelèmis (Kausar 2014). Autoriai nustatè, kad, didejjant kaolinito kiekiui nuo $0 \%$ iki $5 \%$, gniuždymo stipris padidejo nuo 22,5 MPa iki $36,0 \mathrm{MPa}$, atitinkamai, kai tankis kito nuo $400 \mathrm{~kg} / \mathrm{m}^{3}$ iki $1300 \mathrm{~kg} / \mathrm{m}^{3}$, o struktūra pasižymèjo mažesnėmis akutèmis ir didesniu akučių tankiu. Tokių tankių medžiagų terminis stabilumas parodè, kad kaolinitas veikia kaip degumą slopinanti ir termini stabilumą didinanti medžiaga - pradinè irimo temperatūra kito nuo $429^{\circ} \mathrm{C}$ iki $504{ }^{\circ} \mathrm{C}$, o maksimumo temperatūra kito nuo $444{ }^{\circ} \mathrm{C}$ iki $603{ }^{\circ} \mathrm{C}$, atitinkamai, kai kaolinito kiekis kito nuo $0 \%$ iki $5 \%$. Atsižvelgiant ị minètujų mokslininkų tankio ir stiprumo rezultatus, gautos medžiagos gali būti naudojamos konstrukciniuose sprendimuose.

Mokslininkai Galvão et al. 2015 nagrinèjo silikatinio stiklo atliekų (dalelių dydis $0,3-100 \mu \mathrm{m}$ ) panaudojimo statybinèse medžiagose galimybes. Atlikti rentgenografiniai tyrimai parodè, kad šios atliekos cheminè sudètis labai panaši ị PGAD, o šilumos laidumo koeficientas $-0,161 \mathrm{~W} /(\mathrm{m} \cdot \mathrm{K})$. Gauti rezultatai mokslininkams leido daryti išvadą, jog silikatinio stiklo atliekos gali būti naudojamos termoizoliacinių medžiagų ar jų kompozitų gamyboje. Todèl tolimesni autorių Marhoon 2016 tyrimai atlikti su $\mathrm{SiO}_{2}$ mikrodulkèmis. Jie nustatè, kad ị polimerinę matricą įvedus nuo $0 \%$ iki $4 \% \mathrm{SiO}_{2}$ mikrodulkių, gaunami gaminiai, kurių gniuždymo stipris dideja nuo $380 \mathrm{kPa}$ iki $430 \mathrm{kPa}$, o tankis - nuo $59,8 \mathrm{~kg} / \mathrm{m}^{3}$ iki $72,5 \mathrm{~kg} / \mathrm{m}^{3}$. Kai užpildo kiekis sistemoje kinta nuo $6 \%$ iki $10 \%$, gniuždymo stipris sumažèja nuo $360 \mathrm{kPa}$ iki $270 \mathrm{kPa}$, o tankis padidèja nuo $74,8 \mathrm{~kg} / \mathrm{m}^{3}$ iki $82,9 \mathrm{~kg} / \mathrm{m}^{3}$. Vandens sugerties tyrimai parodè, $\mathrm{kad} \mathrm{SiO}_{2}$ mikrodulkès lemia uždaraporès struktūros formavimąsi, todèl, ị polimerinę sistemą įvedus nuo $0 \%$ iki $10 \% \mathrm{SiO}_{2}$ mikrodulkių, minètasis parametras sumažèja nuo $1,3 \%$ iki $0,60 \%$.

\subsection{Ivairių užpildų poveikis poliuretano putų savybèms}

Poliuretano ir poliizocianurato putos pasižymi mažu terminiu stabilumu, dideliu degumu, jautrumu aukštesnèms temperatūroms gaisro metu, o augalinių aliejų polioliu pagrindu pagamintos poliuretano ir poliizocianurato putos - prastesnemis 
nei tradicinių putų mechaninėmis savybėmis (Yan et al. 2012; Janik et al. 2014). Stiprumas gali būti didinamas, mažinant akučių dydị (Shams et al. 2015), o terminis stabilumas ir degumo charakteristikos - naudojant degumą slopinančias medžiagas.

Gerai žinoma, kad priešgaisrinis saugumas yra vienas iš pagrindinių reikalavimų, keliamų statybinèms medžiagoms. Šie reikalavimas labiausiai yra susiję su žmonių saugumu. Gaisro atveju žmonių žūtị sukelia ne liepsna, bet dūmai ir toksinès medžiagos, kurių kiekius lemia šilumos išsiskyrimo greitis. Šis parametras yra viena iš svarbiausių gaisrinių savybių. Didelis išskirtos šilumos kiekis pradinèje gaisro fazèje intensyvina degimo procesą ir lemia greitą temperatūros pakilimą gaisro apimtoje patalpoje. Pagrindinių, gaisrą lemiančių, parametrų gerinimui papildomai gali būti naudojamos degumą slopinančios medžiagos. Yra penkios šių medžiagų rūšys: neorganiniai užpildai, organiniai fosforo junginiai, azoto pagrindu gautos medžiagos, halogenintos medžiagos ir medžiagos, veikiančios barjero principu. Organinių fosforo junginiu sudètyje yra fosforo, o halogenintose medžiagose anglis formuoja jungtis su chloru ir bromu. Šios degumą slopinančios medžiagos nėra biologiškai skaidžios ir yra linkusios kauptis gamtoje (Segev et al. 2009). Azoto pagrindu gautos medžiagos darbuotojus, dirbančius su šiais chemikalais, veikia kaip alergenas. Neorganinès degumą slopinančios medžiagos yra metalų hidroksidai, pavyzdžiui, aliuminio ar magnio. Daug tyrimų atlikta, norint išsiaiškinti sinergijos efektą tarp neorganinių ir kenksmingų žmogui bei aplinkai degumą slopinančių medžiagų: plètriojo grafito ir dimetilo metilo fosfonato (Feng, Qian 2014), plètriojo grafito ir aliuminio hipofosfito (Xu et al. 2015), plètriojo grafito ir trietilo fosfato (Zhang et al. 2013) bei polisiloksano ir cinko borato (Yang et al. 2013). Halogenintos ir bromintos degumą slopinančios medžiagos yra kenksmingos ir ateityje nebus naudojamos, todèl ieškoma būdų, kaip šias medžiagas pakeisti kitomis, žmogui ir aplinkai nekenksmingomis, degumą slopinančiomis medžiagomis, todèl degumo, terminio stabilumo, stiprumo charakteristikoms bei galutinio gaminio struktūros formavimui pagerinti imta naudoti įvairius organinius ir neorganinius užpildus.

Gerai žinoma, kad aerogelis yra priskiriamas labai mažo tankio, kietoms ir labai poringoms medžiagoms, turinčioms didelị paviršiaus plotą (Tang et al. 2015), todèl didelis dèmesys pradètas skirti aerogelių iš metalų oksidų kūrimui, pavyzdžiui, silicio $\left(\mathrm{SiO}_{2}\right)$, aliuminio $\left(\mathrm{Al}_{2} \mathrm{O}_{3}\right)$ ir titano $\left(\mathrm{TiO}_{2}\right)($ Feinle, Hüsing 2015), taip pat iš anglies (Sun et al. 2013), anglies nanovamzdelių (Wimalasiri, Zou 2013), grafeno (Hong et al. 2015) ir molio (Huang, Fan 2016). Pastaraisiais metais didelis susidomejimas skiriamas termoizoliaciniams ir degumui atspariems aerogeliams. Mokslininkai Zhao et al. 2015 poliizocianurato putas armavo $\mathrm{SiO}_{2}$ aerogeliu, kuris, lyginant su kontrolinèmis putomis, lèmé $34,6 \%$ geresni riboto deguonies indeksą (LOI), 32,7 \% mažesni šilumos laidumo koeficientą ir $136 \%$ didesni gniuždymo stiprị, esant $8 \%$ aerogelio. Atlikti tyrimai 
parodè, kad tinkamiausi termoizoliaciniai aerogeliai gali būti gaminami iš silicio, o atsparumo degumui ir terminio stabilumo užtikrinimui polimerinèse sistemose tikslingiausia naudoti aerogelius iš metalų oksidų ir molio. Chen et al. 2014 pagamino polimerinę medžiagą iš polivinilo acetato (PVA), silicio bei montmorilonito ir atliko terminio stabilumo bei degumo bandymus, kurių metu paaiškejjo, kad šilumos išsiskyrimo greitis sumažinamas beveik $70 \%$, lyginant su kontroliniais PVA gaminiais. Taip pat autoriai Motahari et al. 2015 išsiaiškino, kad polimerinių medžiagų, pavyzdžiui, polistireno, polipropileno ir poliamido terminès ir degumo savybės gali būti pagerintos naudojant silicio aerogelių lydalą, kaip degumą slopinančią medžiagą. Atsparumo degumui užtikrinimui poliuretano putose autoriai Xie et al. 2017 naudojo aliuminio oksidą. 20 \% šio aerogelio sumažino šilumos išsiskyrimo greiti poliuretano putų degimo metu nuo $349 \mathrm{~kW} / \mathrm{m}^{2}$ iki $71 \mathrm{~kW} / \mathrm{m}^{2}$, tačiau padidino šilumos laidumo koeficientą nuo $0,040 \mathrm{~W} /(\mathrm{m} \cdot \mathrm{K})$ iki $0,054 \mathrm{~W} /(\mathrm{m} \cdot \mathrm{K})$. Kiti autoriai (Savas et al. 2017) naudojo huntito ir hidromagnezito mineralus kartu su mikrokapsuliuotu raudonuoju fosforu, kurių sistema turejjo labai žymų teigiamą poveiki poliuretano šilumos išsiskyrimo greičiui. 50 \% šių medžiagų poliuretano putose $(40 \%, 43 \%$ ir $45 \%$ huntito ir magnezito mineralų bei $10 \%, 7 \%$ ir $5 \%$ mikrokapsuliuoto raudonojo fosforo) sumažino minètaji parametrą nuo $668 \mathrm{~kW} / \mathrm{m}^{2}$ iki, atitinkamai $162 \mathrm{~kW} / \mathrm{m}^{2}, 155 \mathrm{~kW} / \mathrm{m}^{2}$ ir $214 \mathrm{~kW} / \mathrm{m}^{2}$. Taip pat buvo galima pastebèti, kad, lyginant su kontrolinèmis poliuretano putomis, šių priedų sistema padidina laiko tarpą, reikalingą medžiagai sudegti. Mokslininkai Jiao et al. 2015 tirdami sinergijos efektą tarp metalų miltelių ir amonio polifosfato poliuretano putose išsiaiškino, jog nuo $0,6 \%$ iki 3,8 \% metalų miltelių ir nuo $16,3 \%$ iki $19,4 \%$ amonio polifosfato sumažina visų gaminių irimo pradžios temperatūrą nuo $309,2{ }^{\circ} \mathrm{C}$ iki $287,5^{\circ} \mathrm{C}$ ir suirimo temperatūrą nuo $440,0{ }^{\circ} \mathrm{C}$ iki $340,0^{\circ} \mathrm{C}$.

Efektyviausia medžiaga terminio stabilumo didinimui ir degumo slopinimui šiuo metu yra plètrusis grafitas, naudojamas kartu su kitomis degumą slopinančiomis medžiagomis. Autoriai Wang et al. 2016 ištyrè, jog pentaeritritolo fosfato ir plètriojo grafito sinergijos efektas pasireiškia per pastarojo gebą suformuoti iš plètriojo grafito armuotą anglingaji sluoksni, kurio formavimasis sumažina šilumos išsiskyrimo greiti nuo $323 \mathrm{~kW} / \mathrm{m}^{2}$ iki $113 \mathrm{~kW} / \mathrm{m}^{2}$, dūmų išsiskyrimo greiti nuo $902 \mathrm{~m}^{2} / \mathrm{m}^{2}$ iki $236 \mathrm{~m}^{2} / \mathrm{m}^{2}$ ir anglies monoksido kieki nuo $0,24 \mathrm{~kg} / \mathrm{kg}$ iki $0,20 \mathrm{~kg} / \mathrm{kg}$.

Didelis grafito ir poliuretano putų sistemos atsparumas ugniai grindžiamas apanglejjusio sluoksnio formavimusi ir degimo metu pasireiškiančios redukcijos reakcijos. Ši reakcija pasireiškia tarp $\mathrm{H}_{2} \mathrm{SO}_{4}$, esančio tarp grafito sluoksnių ir paties grafito, kuomet išsiskiria dujos $\left(\mathrm{CO}_{2}\right.$ ir $\left.\mathrm{SO}_{2}\right)$. Šio proceso metu sumažinamas šilumos ir masès perdavimas, dèl to sulèteja medžiagos irimas (Modesti, Lorenzetti 2002). Tokiu būdu LOI poliuretano putose padidèja nuo $27 \%$ iki $41 \%$, tačiau dèl nepakankamo sukibimo su polimerine matrica bei per didelio dalelių 
dydžio grafito panaudojimas lemia prastesnes stiprumines savybes (Feng, Qian 2014). Panašiomis stiprumo ir LOI kitimo tendencijomis pasižymejjo autorių Guler et al. 2017 gauti rezultatai. Jie naudojo plètruji grafitą kartu su huntito ir hidromagnezito mineralais ir pastebejjo, kad šie du komponentai poliuretano putose rodo žymų sinergijos efektą (kiekis 1:1). Papildomai padaryti tyrimai kūginiu kalorimetru parodè, kad šių dviejų medžiagų panaudojimas ịgalina sumažinti šilumos išsiskyrimo greitị daugiau nei perpus, lyginant su kontrolinėmis poliuretano putomis, tačiau $\sim 139 \%$ sumažina tempimo stiprị.

Autoriai Kurańska et al. 2016 tyrè plètriojo grafito kiekio poveikị standžiujuu poliuretano putu terminèms savybèms ir degumo charakteristikoms ir nustatè, kad, ịvedant ị polimerinę sistema nuo $0 \%$ iki $9 \%$ plètriojo grafito, maksimalus šilumos išsiskyrimo greitis sumažinamas nuo $240 \mathrm{~kW} / \mathrm{m}^{2} \mathrm{iki} 136 \mathrm{~kW} / \mathrm{m}^{2}$, pradinè irimo temperatūra - nuo $283^{\circ} \mathrm{C}$ iki $280^{\circ} \mathrm{C}$, o suirimo temperatūra padidinama nuo $450,1^{\circ} \mathrm{C}$ iki $463,4{ }^{\circ} \mathrm{C}$. Panašius rezultatus gavo ir mokslininkai Xi et al. 2015, kuomet suformuotos poliuretano putos su $8 \%$ grafito pasižymejjo nuo $322 \mathrm{~kW} / \mathrm{m}^{2}$ iki $140 \mathrm{~kW} / \mathrm{m}^{2}$ sumažejusiu maksimaliu šilumos išsiskyrimo greičiu.

Taip pat nustatyta, kad ši medžiaga lemia mažesni gaminių gniuždymo stiprị, kuris, kintant plètriojo grafito kiekiui nuo $0 \%$ iki $9 \%$ kito, atitinkamai nuo $160 \mathrm{kPa}$ iki $100 \mathrm{kPa}$, kai tankis kito nuo $37,5 \mathrm{~kg} / \mathrm{m}^{3}$ iki $41,4 \mathrm{~kg} / \mathrm{m}^{3}(\mathrm{Ku}-$ rańska et al. 2017). Tuo tarpu Xi et al. 2015 poliuretano putu gaminiai pasižymejjo nuo $200 \mathrm{kPa}$ iki $220 \mathrm{kPa}$ didèjančiu gniuždymo stipriu ir mažu šilumos laidumo koeficientu, kintančiu $0,025-0,021 \mathrm{~W} /(\mathrm{m} \cdot \mathrm{K})$ ribose, kai tankis kinta nuo $35,2 \mathrm{~kg} / \mathrm{m}^{3}$ iki $50,4 \mathrm{~kg} / \mathrm{m}^{3}$.

Mokslininkai Zhang et al. 2013 pabandé ịvesti nuo $0 \%$ iki $30 \%$ plètriojo grafito ị poliuretano putų sistemą ir taip padidinti šių gaminių stiprumo charakteristikas bei terminį stabilumą. Jie nustatè, kad, tankiui kintant nuo $36,8 \mathrm{~kg} / \mathrm{m}^{3}$ iki $37,2 \mathrm{~kg} / \mathrm{m}^{3}$, galima gauti plètriuoju grafitu modifikuotas poliuretano putas, pasižyminčias nuo $201 \mathrm{kPa}$ iki $198 \mathrm{kPa}$ mažèjančiu gniuždymo stipriu, nuo 20,1 \% iki $24,5 \%$ didejjančiu LOI, nuo $260,0^{\circ} \mathrm{C}$ iki $269,4^{\circ} \mathrm{C}$ padidejusia terminio irimo pradžios temperatūra, nuo $463,6^{\circ} \mathrm{C}$ iki $467,3{ }^{\circ} \mathrm{C}$ padidejusia suirimo temperatūra, ir, esant $30 \%$ plètriojo grafito, šilumos išsiskyrimo greičiu, lygiu $164,7 \mathrm{~kW} / \mathrm{m}^{2}$.

Kita medžiaga, naudojama poliuretano stipruminių ir terminių savybių gerinimui, yra anglies nanovamzdeliai. Autoriai Zhang et al. 2011 nustatè, kad polistireno tempimo stipris ir tamprumo modulis, naudojant $1 \%$ nanovamzdelių, gali būti padidintas, atitinkamai $35 \%$ ir $25 \%$, o poliuretano, naudojant $0,3 \%$ nanovamzdelių - atitinkamai $16 \%$ ir $25 \%$ (Yan et al. 2012). Nors Kingston et al. 2014 nustate, kad anglies nanovamzdeliai padidina daugumos polimerinių (polipropileno, polietileno, metileno vinilo acetato kopolimero ir epoksidinių dervų) termini stabilumą, Ciecierska et al. 2016 išsiaiškino, kad, kintant nanovamzdelių kiekiui nuo $0,01 \%$ iki $0,1 \%$, irimo pradžios temperatūra padidinama vos $2{ }^{\circ} \mathrm{C}$ nepriklau- 
somai nuo užpildo kiekio. Šie mokslininkai nustatè, kad nanovamzdeliai sumažina akučių dydị, tačiau, tęsdami jau pradètus tyrimus, Espadas - Escalante et al. 2016 išsiaiškino, kad nors anglies nanovamzdeliai veikia kaip užuomazgų susidarymo centrai, šilumos laidumo koeficiento nesumažina, o priešingai - ji padidina nuo $0,026 \mathrm{~W} /(\mathrm{m} \cdot \mathrm{K})$ iki $0,069 \mathrm{~W} /(\mathrm{m} \cdot \mathrm{K})$.

\subsection{Titanatų, silanų ir cirkonatų jungiamosios medžiagos, jụ poveikis mišinių klampai ir galutinių gaminių stiprumui}

Polimerinès sistemos, užpildytos modifikuotomis mikro- arba nanodalelèmis, daugeliu atvejų pasižymi geresnèmis stipruminèmis ir atsparumo degumui savybėmis (Kango et al. 2013), o šių sistemų mišiniai - tinkamomis gamybai reologinėmis savybėmis, tačiau užpildams naudojamos dalelès yra linkusios aglomeruotis bei didinti mišinio klampą, todèl labai svarbu sumažinti dalelių paviršiuje esančią laisvają energiją.

Vienas iš būdų išvengti dalelių aglomeracijos - mechaniškai skaldyti aglomeratus, naudojant šlyties jègą, pavyzdžiui, ultragarsą (Sabzi et al. 2009). Tačiau šis būdas nèra tinkamas dèl ribotos neorganinio užpildo ir polimerinès matricos sąveikos, lyginant su sąveika tarp pačių dalelių. Todèl šiam tikslui gali būti naudojamos cheminès medžiagos, pavyzdžiui, titanatų, silanų, fosfatų arba cirkonatų jungiamosios medžiagos. Tai difunkcinès molekulès, gebančios chemiškai sujungti polimerinę matricą su užpildo paviršiumi, suformuodamos tarp jų molekulinę jungtị.

Tam pačiam tikslui taip pat gali būti naudojamas izocianatas. Mokslininkai Sabzi et al. 2009 analizavo silanų poveikị poliuretano dangoms, armuotoms $\mathrm{TiO}_{2}$ nanodalelėmis. Dalelėmis, kurių paviršius buvo modifikuotas, armuoti galutiniai gaminiai pasižymejjo mažesne klampa ir 3 kartus didesniu tempimo stipriu. Panašius rezultatus gavo ir autoriai Hsiang et al. 2005, kurie $\mathrm{Co}_{2} \mathrm{Z}$ ferito miltelius modifikavo titanatais. Tolimesni tyrimai parodè, kad silanais padengtos $\mathrm{ZnO}$ (Ma et al. 2005), $\mathrm{Fe}_{2} \mathrm{O}_{4}$ (Shen et al. 2006) ir talko (Wah et al. 2000) dalelès lemia tolygesni pasiskirstymą mišinyje (1.9 pav.).

Tien, Wei 2002 pastebejjo, kad poliuretano putų gamyboje naudojamos nemodifikuotos mikro- ir nanodalelès padidina terminị stabilumą. Tai vyksta dèl to, kad paviršiuje esančios hidroksilų grupès reaguoja su kietaisiais matricos segmentais ir formuoja vandenilinę jungti, o autoriai Sabzi et al. 2009 ir Tham et al. 2011 teigia, kad silanais bei titanatais modifikuotos dalelès dar labiau padidina galutinių gaminių terminį stabilumą. Autoriai Han et al. 2008 ištyrè ultragarso poveikị 
poliuretano putų ir silanais dengtų ir nedengtų organiškai modifikuoto filosilikato gaminių gniuždymo stipriui ir šilumos laidumo koeficientui.

Paaiškejjo, kad dalelių paskirstymo mišinyje gerinimui didžiausią poveikį turi dalelių modifikavimas, o ne ultragarso naudojimas. Poliuretano putų su silanais dengtomis dalelèmis šilumos laidumo koeficientas sumažèjo $\sim 6,5 \%$, o gniuždymo stipris padidejo $\sim 1 \%$.
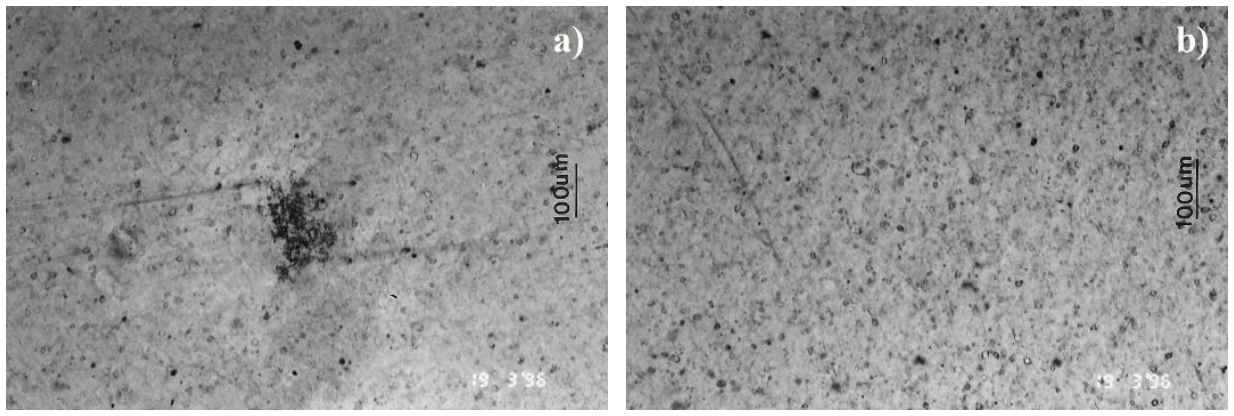

1.9 pav. Dalelių pasiskirstymas talko ir polipropileno sistemoje: a) be titanato jungiamosios medžiagos; b) su $1 \%$ pagal užpildo masę titanato jungiamaja medžiaga (Wah et al. 2000)

Fig. 1.9. Distribution of particles in talc and polypropylene system: a) without titanate coupling agent; b) with 1 wt. \% of titanate coupling agent (Wah et al. 2000)

Autoriai Tham et al. 2011 teigia, kad gaminių su titanatais modifikuotomis dalelèmis tempimo stipriui didelį poveikị turi paviršių modifikuojančiosios medžiagos kiekis bei struktūra. Šiuo atveju tempimo stipris padidejo $19 \%$, kai titanato jungiamosios medžiagos panaudota $2 \%$ nuo užpildo masès.

Autoriai Tayfun et al. 2015 analizavo galimybę augalinès kilmès pluoštų padengimui panaudoti vieną iš poliuretano komponentų - izocianatą. Gerai žinoma, kad augalinès kilmès užpilduose yra ne celiuliozinių priemaišų, t. y. hemiceliuliozès, pektinų, ligninų, vaškų bei dalis amorfinès celiuliozès, kurie daro neigiamą poveiki paviršiaus sudrèkimui ir adhezijai, todėl būtinas tokių užpildų paviršiaus apdirbimas natrio hidroksidu.

Šio proceso metu iš užpildų pašalinami minètieji komponentai, padidinamas paviršiaus šiurkštumas ir hidrofobiškumas (Venkateshwa-ran et al. 2013). Natrio hidroksidu apdirbti ir izocianatu padengti augalinès kilmès pluoštai panaudoti poliuretano sistemose. Gauti rezultatai parode, kad gaminių tempimo stipris padidejo $\sim 17 \%$, o ilgalaikè vandens sugertis visiškai jame panardinus sumažejo nuo $7 \%$ iki $5 \%$. Tai reiškia, kad šios medžiagos pagerina tarpfazini sukibimą tarp polimerinès matricos ir užpildo. 


\subsection{Pirmojo skyriaus išvados ir disertacijos uždavinių formulavimas}

Atlikta literatūros analizè parodè, kad:

1. Mažus hidroksilų $(<290 \mathrm{mg} \mathrm{KOH} / \mathrm{g})$ ir funkcinių grupių $(<3)$ skaičius turinčio poliolio panaudojimas vandeniu išpūstose poliuretano putų sistemose lemia didelius gaminių tiesinių matmenų pokyčius.

2. $70 \%$ tradicinio poliolio iš naftos produktų, naudojamo poliuretano putų gamyboje, gali būti keičiamas biopolioliu iš augalinès kilmès aliejų.

3. $\mathrm{CO}_{2}$ dujų globalinio atšilimo potencialas yra nuo kelių iki kelių šimtų kartų mažesnis nei tradicinių dujodarių, todèl šios dujos yra tinkamiausia alternatyva, kuri pasižymi pagrindiniu trūkumu - dideliais gaminių tiesinių matmenų pokyčiais dẻl per daug intensyvios $\mathrm{CO}_{2}$ dujų difuzijos.

4. Poliuretano putų iš biopoliolių fizikinių ir mechaninių savybių užtikrinimui ir gerinimui naudojama iki $20 \%$ daugiafunkcių organinių junginių iš naftos produktų, tačiau duomenų apie augalinès kilmès junginių panaudojimą nèra.

5. Popieriaus gamybos atliekų dumblas yra poringas, tačiau jo panaudojimo galimybès termoizoliacinių poliuretano putų gamyboje nèra tirtas.

6. Nuo $1 \%$ iki $3 \%$ titanato jungiamosios medžiagos užtikrina tinkamą mišinių klampą, iki $20 \%$ padidina polimerinių medžiagų tempimo ir gniuždymo stiprius bei $2 \%$ sumažina vandens sugertị.

Užsibrezžtam darbo tikslui pasiekti reikia spręsti šiuos uždavinius:

1. Ištirti vandens poveiki poliuretano putu pradinei susitraukčiai, matmenų stabilumui padidintos temperatūros ir drégmès sąlygomis bei tankiui.

2. Ištirti propilenglikolio iš rapsų glicerino ir rapsų glicerino poveiki standžiụjų poliuretano putų fizikinėms ir mechaninèms savybėms.

3. Ištirti titanato jungiamaja medžiaga padengtų popieriaus gamybos atliekų dumblo dalelių poveikị propilenglikoliu modifikuotų poliuretano putų reakcijos kinetikai, fizikinėms, mechaninèms ir cheminèms savybėms. 
4. Pateikti rekomendacijas ribiniams propilenglikolio iš rapsų glicerino ir termiškai bei chemiškai apdorotų popieriaus gamybos atliekų dumblo dalelių kiekiams pagal būsimų gaminių gamybos pobūdị, atsižvelgiant ị modifikuotų mišinių reologiją bei fizikines gaminių savybes. 


\section{2}

\section{Naudotos medžiagos ir poliuretano putų tyrimų metodai}

Skyriuje aprašomos standžiosioms poliuretano putoms naudotos medžiagos, popieriaus gamybos atliekų dumblo dalelių padengimo titanato jungiamaja medžiaga technologija, standžiụjų poliuretano putų su skirtingais vandens kiekiais, grandinès plètikliais ir popieriaus gamybos atliekų dumblu modifikuotų poliuretano putų bandinių gamybos technologijos bei savybių tyrimo metodikos.

Skyriaus tematika paskelbti 4 autorès straipsniai (Kairyté, Vèjelis 2015), (Kairytè et al. 2016), (Kairytè et al. 2017a), (Kairytė et al. 2017b).

\subsection{Tyrimams naudotos medžiagos}

Standžiujų poliuretano putų tyrimams naudotas poliesterinis poliolis, susintetintas chemo - fermentiniu būdu iš rapsų aliejaus, naudojant fermentą Novozym 435 (UAB IMD technologies, Lietuva). Poliolis pasižymi 2.1 lentelèje pateiktomis, standžiųjų poliuretano putų gamybai svarbiomis, savybėmis.

Siekiant nemažinti atsinaujinančios dalies galutiniuose gaminiuose kiekio, papildomai naudojant daugiafunkcius poliolius iš naftos produktų, popieriaus ga- 
mybos atliekų dumblo dalelėmis modifikuotų poliuretano putų tyrimuose nuspręsta naudoti nuo $75 \mathrm{dpm}$ iki $90 \mathrm{dpm}$ poliolio iš rapsų aliejaus ir 2.1.2 poskyryje nurodytą kiekị ekologiško grandinès plètiklio.

2.1 lentelè. Poliolio iš rapsų aliejaus fizikinės ir cheminès savybės

Table 2.1. Physical and chemical properties of polyol from rapeseed oil

\begin{tabular}{|l|c|}
\hline \multicolumn{1}{|c|}{ Parametras } & Verte \\
\hline Hidroksilü skaičius, $\mathrm{mg} \mathrm{KOH} / \mathrm{g}$ & 323 \\
\hline Funkcinių grupių skaičius (funkcionalumas), b. d. & 2,7 \\
\hline Tankis, $\mathrm{kg} / \mathrm{m}^{3}$ & 961 \\
\hline Atsinaujinančios dalies medžiagoje kiekis, $\%$ & 100 \\
\hline Dinaminè klampa $25^{\circ} \mathrm{C}$ temperatūroje, $\mathrm{mPa} \cdot \mathrm{s}$ & 328 \\
\hline Rūgščiu skaičius, $\mathrm{mg} \mathrm{KOH} / \mathrm{g}$ & $\sim 1$ \\
\hline Drègmès kiekis, $\%$ & 0,25 \\
\hline Fiziné būkle் & Skystis \\
\hline
\end{tabular}

Vandeniu išpūstų standžiujų poliuretano putu pradinès susitraukties mažinimo ir matmenų stabilumo padidintos temperatūros ir drègmès sąlygomis užtikrinimo efektyvumo tyrimams naudoti du grandinès plètikliai - propilenglikolis iš rapsų glicerino (RPG) (ADM Industrials, Vokietija) ir rapsų glicerinas (RGL) (H Plus Limited, Anglija). Pagrindinès fizikinès ir cheminès savybès, reikalingos tyrimams ir sudèties apskaičiavimui, pateiktos 2.2 lentelèje.

2.2 lentelè. Grandinès plètikliụ fizikinès ir cheminès savybès

Table 2.2. Physical and chemical properties of chain extenders

\begin{tabular}{|l|c|c|}
\hline \multirow{2}{*}{\multicolumn{1}{|c|}{ Parametras }} & \multicolumn{2}{c|}{ Grandinės plètiklis } \\
\cline { 2 - 3 } & RPG & RGL \\
\hline Hidroksilų skaičius, $\mathrm{mg} \mathrm{KOH} / \mathrm{g}$ & 1474 & 1800 \\
\hline Molekulinė masė, $\mathrm{g} / \mathrm{mol}$ & 76,1 & 92,1 \\
\hline Funkcionalumas, $\mathrm{b}$. $\mathrm{d}$. & 2 & 3 \\
\hline Tankis, $\mathrm{kg} / \mathrm{m}^{3}$ & 1035 & 1261 \\
\hline Dinaminè klampa $25^{\circ} \mathrm{C}$ temperatūroje, $\mathrm{mPa} \cdot \mathrm{s}$ & 302 & 534 \\
\hline Rūgščių skaičius, $\mathrm{mg} \mathrm{KOH} / \mathrm{g}$ & $\sim 2$ & $\sim 2$ \\
\hline Drègmès kiekis, \% & 0,13 & $<0,5$ \\
\hline Atsinaujinančios dalies medžiagoje kiekis, $\%$ & 97 & 97 \\
\hline
\end{tabular}

Tyrimams pasirinktas grandinès plètiklio tipas - RPG, kurio poliolio mišinyje naudota $10 \mathrm{dpm}, 15 \mathrm{dpm}$ ir $20 \mathrm{dpm}$. 
Standžiųjų poliuretano putų struktūros formavimui ekologiška alternatyva tradiciniams dujodariams pasirinktas distiliuotas vanduo, kurio reakcijos su izocianatu metu išsiskiria $\mathrm{CO}_{2}$ dujos.

Standžiujų poliuretano putų kietinimui naudotas 4,4'-difenilmetano diizocianatas (toliau tekste izocianatas) Lupranat M20S (BASF, Vokietija), kurio vidutinis funkcionalumas 2,7 ir reaguojančių grupių $(-\mathrm{NCO})$ kiekis $31,5 \%$. Izocianato indeksas -125 .

Popieriaus gamybos atliekų dumblas yra ( $\mathrm{AB}$ Grigeo Grigiškès, Lietuva) maišytos higieninio ir pakavimo popierių, korinių užpildų, gofruotų kartonų ir pakuočiu gamybos atliekos, susidarančios atliekinio vandens valymo įrenginiuose. Pradinis šių atliekų drègnis - $39 \%$. Atliktos kiekybinè ir kokybinè (2.3 lentelè ir 2.1 paveikslas) analizès parodè, kad didžiają dali termiškai apdorotų PGAD dalelių (toliau PGAD dalelès) sudaro $\mathrm{CaCO}_{3}$.

2.3 lentelė. Kiekybinè popieriaus gamybos atliekų dumblo dalelių cheminè sudètis

Table 2.3. Quantitative chemical composition of paper production waste sludge particles

\begin{tabular}{|c|c|c|c|c|}
\hline \multicolumn{5}{|c|}{ Masès, \% } \\
\hline $\mathrm{SiO}_{2}$ & $\mathrm{Al}_{2} \mathrm{O}_{3}$ & $\mathrm{CaO}$ & $\mathrm{MgO}$ & $\mathrm{Fe}_{2} \mathrm{O}_{3}$ \\
\hline $5,8-6,0$ & $4,6-4,8$ & $48,5-49,5$ & $0,4-0,5$ & $0,5-0,6$ \\
\hline \multicolumn{5}{|c|}{$\mathrm{Masès}, \%$} \\
\hline $\mathrm{Na}_{2} \mathrm{O}$ & $\mathrm{K}_{2} \mathrm{O}$ & $\mathrm{SO}_{3}$ & $\mathrm{P}_{2} \mathrm{O}_{5}$ & Kiti $^{*}$ \\
\hline $0,03-0,04$ & $0,14-0,15$ & $0,17-0,20$ & $0,05-0,06$ & $13,9-18,7$ \\
\hline
\end{tabular}

${ }^{*} \mathrm{Cl}, \mathrm{MnO}, \mathrm{NiO}, \mathrm{CuO}, \mathrm{ZnO}, \mathrm{Br}, \mathrm{Rb}_{2} \mathrm{O}, \mathrm{SrO}, \mathrm{BaO}, \mathrm{Nb}_{2} \mathrm{O}_{5}, \mathrm{Cr}_{2} \mathrm{O}_{3}$.

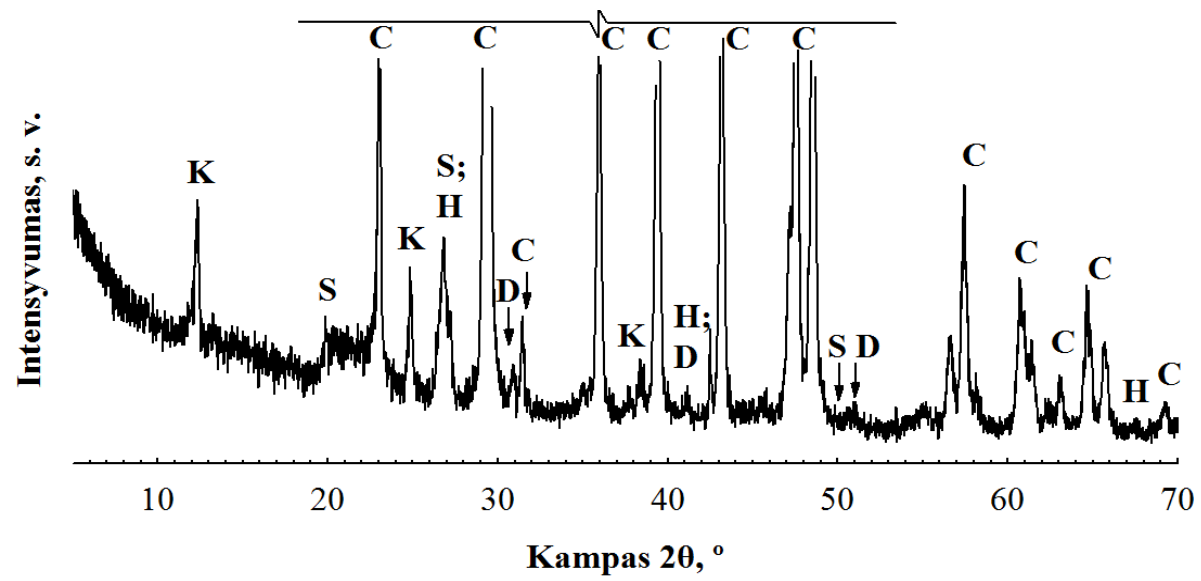

2.1 pav. Popieriaus gamybos atliekų dumblo dalelių rentgenograma: $\mathrm{K}$ - kaolinitas; $\mathrm{H}$ - haloisitas; $\mathrm{S}$ - silicio dioksidas; $\mathrm{C}$ - kalcio karbonatas; D - dolomitas

Fig. 2.1. $X$-ray curve of paper production waste sludge particles: $\mathrm{K}$ - kaolinite; $\mathrm{H}$ - halloysite; $\mathrm{S}$ - silica; $\mathrm{C}$ - calcium carbonate; $\mathrm{D}$ - dolomite 
Kitos smailès rentgenogramoje nurodo kaolinito, haloisito, silicio dioksido ir dolomito buvimą. Paaiškejjus, kad PGAD dalelių sudètyje yra anglies, nustatytas organinès dalies kiekis, kuris svyruoja nuo 21,1\% iki 24,3\%.

Organinès ir neorganinès PGAD dalelių dalių nuotraukos skenuojančiuoju elektroniniu mikroskopu pateiktos $2.2 \mathrm{a}$ ir b paveiksluose.
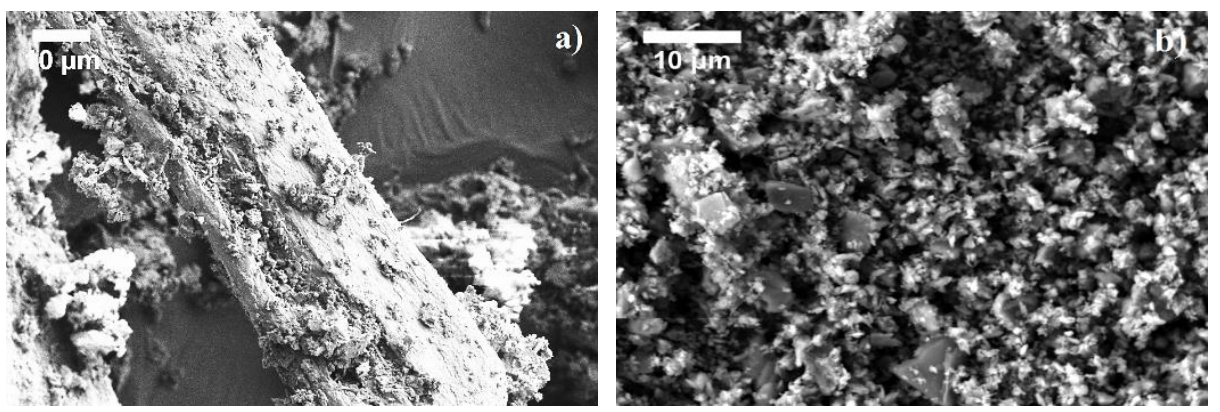

2.2. Popieriaus gamybos dumblo dalelès: a) celiuliozès plaušelis (didinimas $\times 2000$ );

b) neorganinès dalelès po organinès dalies išdegimo (didinimas $\times 2000$ )

Fig. 2.2. Paper production waste sludge particles: a) cellulose fiber (magnification $\times 2000$ ); b) inorganic particles after burning out of organic matter (magnification $\times 2000$ )

Galima pastebèti, kad organinę PGAD dalelių dalị sudaro mediena bei trumpi celiuliozès plaušeliai. Dalelių pasiskirstymas pagal dydị pateiktas 2.3 paveiksle.

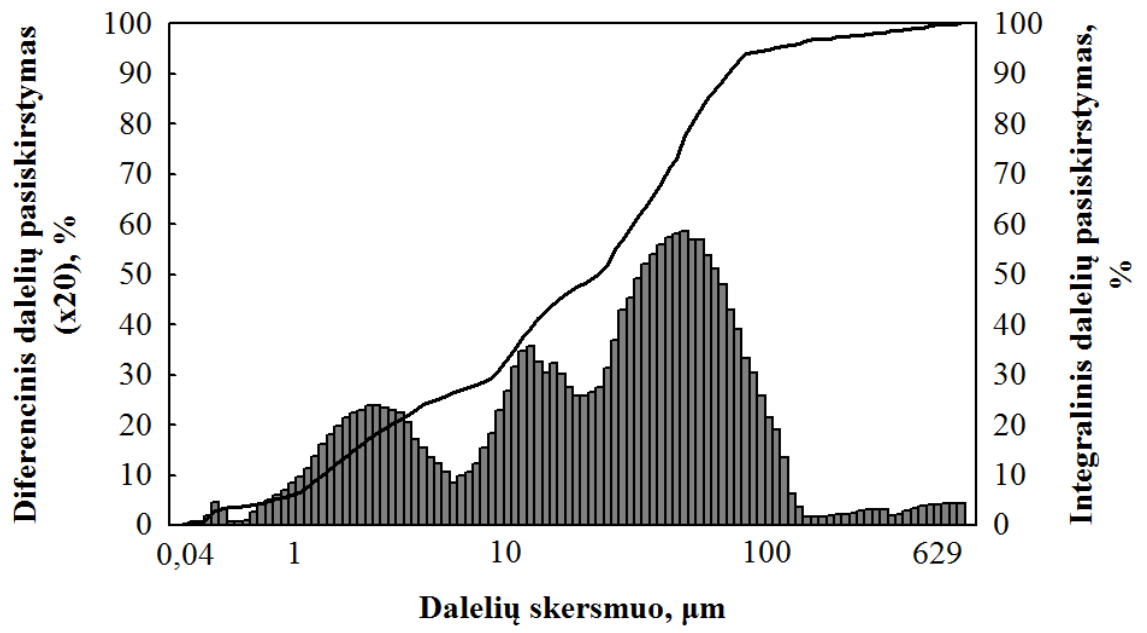

2.3 pav. Popieriaus gamybos atliekų dumblo dalelių pasiskirstymas pagal dydị

Fig. 2.3. Size distribution of paper production waste sludge particles 
Nustatyta, kad PGAD dalelių dydis kinta nuo 0,4 $\mu \mathrm{m}$ iki $629 \mu \mathrm{m} .90 \%$ šių atliekų sudare 1-100 $\mu \mathrm{m}$ dydžio dalelès. Norint kokybiškai ịvertinti PGAD dalelių poveikị standžiosioms RPG modifikuotoms poliuretano putoms, svarbu žinoti pagrindines šių dalelių fizikines savybes (2.4 lentelè).

2.4 lentelè. Pagrindinès popieriaus gamybos atliekų dumblo dalelių fizikinės ir mechaninès savybès

Table 2.4. The main physical and mechanical properties of paper production waste sludge particles

\begin{tabular}{|c|c|c|c|}
\hline $\begin{array}{c}\text { Šilumos laidumo koe- } \\
\text { ficientas, } \\
\mathrm{W} /(\mathrm{m} \cdot \mathrm{K})\end{array}$ & $\begin{array}{c}\text { Piltinis tankis, } \\
\mathrm{g} / \mathrm{cm}^{3}\end{array}$ & $\begin{array}{c}\text { Paviršiaus plotas, } \\
\mathrm{cm}^{2} / \mathrm{g}\end{array}$ & $\begin{array}{c}\text { Drėgmès kiekis, } \\
\%\end{array}$ \\
\hline $0,084 \pm 0,00150$ & $0,48 \pm 0,0440$ & $7110 \pm 20,2$ & $1,5 \pm 0,162$ \\
\hline
\end{tabular}

Adhezijos tarp PGAD dalelių ir polimerinès matricos gerinimui naudota tris(3,6-diaza) heksanolato titanato jungiamoji medžiaga TCA - K44 (Capatue Chemicals, Kinija), kurios molekulinè formule $\mathrm{C}_{15} \mathrm{H}_{40} \mathrm{O}_{4} \mathrm{TiN}_{6}$. Pagrindinès TCA - K44 savybès pateiktos 2.5 lentelèje.

2.5 lentelè. Pagrindinès titanato jungiamosios medžiagos savybès

Table 2.5. The main properties of titanate coupling agent

\begin{tabular}{|c|c|c|c|c|}
\hline Fizinè forma & $\begin{array}{c}\text { Virimo tem- } \\
\text { peratūra, }{ }^{\circ} \mathrm{C}\end{array}$ & Tirpumas & $\begin{array}{c}\text { Dinaminè } \\
\mathrm{klampa}, \mathrm{mPa} \cdot \mathrm{s}\end{array}$ & Tankis $\mathrm{g} / \mathrm{cm}^{3}$ \\
\hline $\begin{array}{c}\text { Geltonai rudas } \\
\text { skystis }\end{array}$ & $>200$ & $\begin{array}{c}\text { Izopropilo al- } \\
\text { koholyje, mi- } \\
\text { neraliniame a- } \\
\text { liejuje ir } \\
\text { toluene }\end{array}$ & 5000 & 1,105 \\
\hline
\end{tabular}

Literatūros apžvalga parodè, kad efektyviausias tempimo ir gniuždymo stiprių, ilgalaikès vandens sugerties bei pralaidumo vandens garui atžvilgiu titanato jungiamosios medžiagos kiekis yra $1 \%$ pagal užpildo masę.

Poliuretano putų formavimui naudota polieteriu modifikuota polisiloksano paviršių aktyvinanti medžiaga Tegostab B 1048 (Evonik, Vokietija). Paviršiaus ìtempimų mažinimui ir tolygios akytosios struktūros formavimui bei stabilizavimui naudotas 2,0 dpm kiekis pasirinktas remiantis gamintojo rekomendacijomis (nuo 1,0 dpm iki 2,5 dpm) ir atlikta literatūros analize.

Standžiųu poliuretano putų pagrindinių reakcijų būdingụjų laikų kontroliavimui naudoti išpūtimo ir standejjimo katalizatoriai, atitinkamai N,N-dimetiletanolaminas Lupragen N101 (BASF, Vokietija), kurio molekulinė formulè 
$\mathrm{C}_{4} \mathrm{H}_{11} \mathrm{NO}$, ir 1,2-dimetilimidazolas Lupragen DMI (BASF, Vokietija), kurio molekulinè formulè $\mathrm{C}_{5} \mathrm{H}_{8} \mathrm{~N}_{2}$.

Vandens ir grandinès plètiklių poveikio standžiujų poliuretano putų fizikinių ir mechaninių savybių tyrimams naudotas išpūtimo katalizatoriaus kiekis $0,9 \mathrm{dpm}$, o standejjimo - 1,2 dpm. RPG bei PGAD dalelėmis modifikuotų poliuretano putų tyrimams katalizatorių kiekiai perskaičiuoti.

Išpūtimo katalizatoriaus kiekio parinkimas (1,2 dpm) kontrolinėms RPG modifikuotoms poliuretano putoms paremtas laiku, reikalingu komponentu išmaišymui ir supylimui i formas $25 \div 30$ s laiko intervale. Standejjimo katalizatoriaus kiekis $(1,8 \mathrm{dpm})$ parinktas pagal būdingaji standèjimo pradžios laiką $55 \div 135$ s laiko intervale neišpurškiamoms poliuretano putoms. Abiejų katalizatorių kiekiai parinkti priartejimo būdu (2.6 lentelè). Paryškintos 2.6 lentelejje skaitinès vertės nurodo tinkamus katalizatorių kiekius standžiujų poliuretano putų gamybai.

2.6 lentelè. Pagrindiniai standžiujų poliuretano putų reakcijų būdingieji laikai Table 2.6. The main characteristic times of rigid polyurethane foam reactions

\begin{tabular}{|l|c|c|c|c|}
\hline \multirow{2}{*}{ Tyrimų stadija } & \multicolumn{2}{|c|}{ Katalizatoriaus kiekis, dpm } & \multirow{2}{*}{$\begin{array}{c}\text { Tirštejjimo } \\
\text { laikas, s }\end{array}$} & $\begin{array}{c}\text { Standèjimo } \\
\text { laikas, s }\end{array}$ \\
\cline { 2 - 3 } & $\begin{array}{c}\text { Lupragen } \\
\text { N101 }\end{array}$ & $\begin{array}{c}\text { Lupragen } \\
\text { DMI }\end{array}$ & & 102 \\
\hline $\begin{array}{l}\text { Vandens ir grandinès } \\
\text { plètiklio tipo bei kie- } \\
\text { kio parinkimas }\end{array}$ & 0,9 & 1,2 & 37 & 67 \\
\hline $\begin{array}{l}\text { RPG ir PGAD daleliu } \\
\text { poveikis }\end{array}$ & 1,2 & 1,5 & 27 & 64 \\
\cline { 2 - 5 } & 1,2 & 1,8 & 25 & 67 \\
\hline
\end{tabular}

Titanato jungiamosios medžiagos tirpinimui naudotas $99,5 \%$ izopropilo alkoholis (CVB Albert Carl, Vokietija), kurio virimo temperatūra $82,6{ }^{\circ} \mathrm{C}$.

\subsection{Popieriaus gamybos atliekų dumblo ir poliuretano putų paruošimas tyrimams}

\section{Popieriaus gamybos atliekų dumblo paruošimas ir dalelių padengimas titanato jungiamaja medžiaga}

Perteklinès drègmès šalinimui PGAD 24 val. džiovintas $70 \pm 5{ }^{\circ} \mathrm{C}$ temperatūros sąlygomis ventiliuojamoje džiovinimo spintoje. Išdžiovintas akmens pavidalo PGAD buvo skaldomas, malamas ir sijojamas per $0,63 \mathrm{~mm}$ dydžio sietą. $2 \mathrm{~g}$ (1\% 
pagal užpildo masę) TCA - K44 titanato jungiamosios medžiagos ištirpinta $200 \mathrm{ml}$ izopropilo alkoholyje. Gautas tirpalas buvo pilamas ant buitiniu maišytuvu maišomų $200 \mathrm{~g}$ PGAD dalelių. Tolygiam titanato jungiamosios medžiagos paskirstymui mišinys maišytas papildomai 30 min. Gautas mišinys 48 val. $100 \pm 5^{\circ} \mathrm{C}$ temperatūroje džiovintas ventiliuojamoje džiovinimo spintoje ir 24 val. išlaikytas laboratorinèmis sąlygomis.

\section{Standžiujų poliuretano putų formavimas}

Siekiant parinkti tinkamą vandens kiekį, grandinès plètiklio kiekị bei tipą tirtos sudètys, kuriose naudotas vandens kiekis, dpm: 1,0; 1,5;2,0; 2,5; 3,0; 4,0; 4,5; 5,0; 5,5; 6,0 ir RPG bei RGL, kiekis, dpm: 5; 10; 15; 20; 25 (2.7 ir 2.8 lentelè).

Poliuretano putu su skirtingais vandens kiekiais formavimui poliolis iš rapsų aliejaus, katalizatoriai ir paviršių aktyvinanti medžiaga 1 min. maišyti buitiniu maišytuvu 1800 aps./min. greičiu. Gautas mišinys buvo padalintas ị dešimt lygių dalių, kurių kiekviena padalinta dar ị tris lygias dalis, ị kurias supiltas nurodytas kiekis vandens. Galutinis medžiagų mišinys vadinamas komponentu A. Viską 1 min. maišius, supiltas atitinkamas izocianato (komponento B) kiekis, reikalingas sureaguoti visoms poliolio, grandinès plètiklių ir vandens - $\mathrm{OH}$ grupėms, ir kuris apskaičiuojamas pagal (2.1)-(2.3) formules:

$$
\begin{gathered}
E_{M D I}=\frac{4200}{\% N C O} ; \\
E_{P, R P G, R G L}=\frac{56100}{n_{O H}} ; \\
m_{M D I}=\left(\frac{I_{M D I}}{100}\right) \cdot E_{M D I} \cdot\left(\frac{m_{P}}{E_{P}}+\frac{m_{R P G, R G L}}{E_{R P G, R G L}}+\frac{m_{H_{2} O}}{E_{H_{2} O} O}\right),
\end{gathered}
$$

čia $E_{M D I}$ - izocianato ekvivalentinè masè, g/mol; \%NCO - izocianato reaguojančių grupių procentinis kiekis, \%; $56100-\mathrm{KOH}$ molekulinè masè, mg/mol; 4200 - izocianato molekulinè masè, $\mathrm{mg} / \mathrm{mol} ; E_{P, R P G, R G L}$ - poliolio, RPG ar RGL ekvivalentinė masė, g/mol; $n_{O H}$ - poliolio, RPG ar RGL hidroksilų skaičius, $\mathrm{mg} / \mathrm{KOH} \mathrm{g} ; m_{M D I}$ - izocianato kiekis, dpm; $I_{M D I}$ - numatytasis izocianato indeksas, b. d.; $m_{P, R P G, R G L}-$ poliolio, RPG ar RGL kiekis, dpm; $m_{H_{2} O}-$ vandens kiekis, dpm; $E_{\mathrm{H}_{2} \mathrm{O}}-$ vandens ekvivalentinè masè, $\mathrm{g} / \mathrm{mol}$.

Poliuretano putų su skirtingais grandinès plètiklių kiekiais formavimui buvo paruošta dvylika (6 su RPG ir 6 su RGL) talpų, ị kurias buvo pilami 2.8 lentelèje nurodyti komponento A kiekiai. 
2.7 lentelè. Standžiujų poliuretano putų mišinių su skirtingais vandens kiekiais sudètis Table 2.7. Composition of rigid polyurethane foam mixtures with different amounts of water

\begin{tabular}{|l|c|}
\hline \multicolumn{1}{|c|}{ Medžiaga } & Kiekis, dpm \\
\hline \multicolumn{2}{|c|}{ Komponentas A } \\
\hline Poliolis & 100 \\
\hline Distiliuotas vanduo & \\
\hline Lupragen N101 & 1,$0 ; 1,5 ; 2,0 ; 2,5 ; 3,0 ; 4,0 ; 4,5 ; 5,0 ; 5,5 ; 6,0$ \\
\hline Lupragen DMI & 1,2 \\
\hline Tegostab B 1048 & 1,8 \\
\hline \multicolumn{2}{|c|}{ Komponentas B } \\
\hline Izocianatas & 2,0 \\
\hline
\end{tabular}

${ }^{a}$ Skirtingas vandens kiekis buvo ịvertintas izocianato kiekio skaičiavimuose;

${ }^{\mathrm{b}}$ Izocianato indeksas yra ekvivalentinio ir teorinio izocianato kiekių santykis, padaugintas iš 100 .

2.8 lentelè. Standžiujų poliuretano putų mišinių su skirtingais grandinės plètiklių kiekiais sudètis

Table 2.8. Composition of rigid polyurethane foam mixtures with different amounts of chain extenders

\begin{tabular}{|l|c|c|c|c|c|c|c|}
\hline \multicolumn{7}{|c|}{ Medžiaga } & \multicolumn{7}{|c|}{ Kiekis, dpm } \\
\hline \multicolumn{7}{|c|}{ Komponentas A, dpm } \\
\hline Poliolis & 100 & 95 & 90 & 85 & 80 & 75 \\
\hline RPG ir RGL kiekis ${ }^{\mathrm{a}}$ & 0 & 5 & 10 & 15 & 20 & 25 \\
\hline Distiliuotas vanduo & 3,0 & 3,0 & 3,0 & 3,0 & 3,0 & 3,0 \\
\hline Lupragen N101 & 1,2 & 1,2 & 1,2 & 1,2 & 1,2 & 1,2 \\
\hline Lupragen DMI & 1,8 & 1,8 & 1,8 & 1,8 & 1,8 & 1,8 \\
\hline Tegostab B 1048 & 2,0 & 2,0 & 2,0 & 2,0 & 2,0 & 2,0 \\
\hline \multicolumn{7}{|c|}{ Indeksas 125 } \\
\hline Kzocianatas & \multicolumn{7}{|c|}{ B, dpm } \\
\hline $\begin{array}{l}\text { Perskaičiuotas vandens kiekis RPG sudè- } \\
\text { tims }\end{array}$ & 2,75 & 2,76 & 2,76 & 2,77 & 2,77 & 2,78 \\
$\begin{array}{l}\text { Perskaičiuotas vandens kiekis RGL sudè- } \\
\text { tims }\end{array}$ & 2,75 & 2,74 & 2,73 & 2,71 & 2,70 & 2,69 \\
\hline
\end{tabular}

${ }^{a}$ RPG ir RGL hidroksilų skaičiai buvo ịvertinti izocianato kiekio skaičiavimuose;

${ }^{\mathrm{b}}$ Bendras drègmès kiekis, esantis poliolyje, RPG ir RGL, buvo perskaičiuotas distiliuoto vandens kiekiui, reikalingam bandinių išpūtimui.

Kiekvienas iš gautu mišiniu padalintas dar i tris dalis, $i$ kurias buvo pilamas perskaičiuotas kiekis vandens ir atitinkamas kiekis komponento B. Mišiniai buvo 
maišomi $10 \mathrm{~s}$ ir pilami i $400 \times 400 \times 100 \mathrm{~mm}$ dydžio formą, kurioje jie nevaržomai pūtèsi $23 \pm 2{ }^{\circ} \mathrm{C}$ temperatūroje. Prieš bandymus bandiniai 24 val. išlaikyti $23 \pm 5{ }^{\circ} \mathrm{C}$ temperatūros ir $50 \pm 5 \%$ santykinès oro drègmès aplinkoje.

\section{Propilenglikoliu ir popieriaus gamybos atliekų dumblo dalelèmis modifikuotų poliuretano putų formavimas}

Pagal vandens ir grandinès plètiklių kiekio poveikị kontrolinių poliuretano putų fizikinėms ir mechaninèms savybèms (3.1 ir 3.2 poskyriai) modifikuotu poliuretano putų tyrimams pasirinkti PGAD dalelių ir kitų žaliavų kiekiai pateikiami 2.9 lentelèje.

2.9 lentelè. Propilenglikoliu ir popieriaus gamybos atliekų dumblo dalelèmis modifikuotų poliuretano putų sudettis

Table 2.9. Composition of propylene glycol and paper production waste sludge particles modified polyurethane foam

\begin{tabular}{|c|c|c|c|c|c|}
\hline Medžiaga & \multicolumn{5}{|c|}{ Kiekis, dpm } \\
\hline \multicolumn{6}{|c|}{ Komponentas A } \\
\hline Poliolis & $\begin{array}{c}90 ; 85 \\
80 \\
\end{array}$ & $\begin{array}{c}90 ; 85 \\
80 \\
\end{array}$ & $\begin{array}{c}90 ; 85 \\
80 \\
\end{array}$ & $\begin{array}{c}90 ; 85 \\
80 \\
\end{array}$ & $\begin{array}{c}90 ; 85 \\
80 \\
\end{array}$ \\
\hline RPG & $\begin{array}{c}10 ; 15 \\
20\end{array}$ & $\begin{array}{c}10 ; 15 \\
20\end{array}$ & $\begin{array}{c}10 ; 15 \\
20\end{array}$ & $\begin{array}{c}10 ; 15 \\
20\end{array}$ & $\begin{array}{c}10 ; 15 \\
20\end{array}$ \\
\hline Distiliuotas vanduo & 3,0 & 3,0 & 3,0 & 3,0 & 3,0 \\
\hline Lupragen N101 & 1,2 & 1,2 & 1,2 & 1,2 & 1,2 \\
\hline Lupragen DMI & 1,8 & 1,8 & 1,8 & 1,8 & 1,8 \\
\hline Tegostab B 1048 & 2,0 & 2,0 & 2,0 & 2,0 & 2,0 \\
\hline PGAD dalelès, $\%$ & 0 & 5 & 10 & 15 & 20 \\
\hline \multicolumn{6}{|c|}{ Komponentas B } \\
\hline Izocianatas & \multicolumn{5}{|c|}{ Indeksas 125} \\
\hline Perskaičiuotas vandens kiekis ${ }^{\mathrm{a}}$ & $\begin{array}{c}2,76 \\
2,77 \\
2,77\end{array}$ & $\begin{array}{l}2,54 \\
2,53 \\
2,53\end{array}$ & $\begin{array}{c}2,32 \\
2,30 \\
2,28\end{array}$ & $\begin{array}{l}2,10 \\
2,07 \\
2,04\end{array}$ & $\begin{array}{l}1,88 \\
1,84 \\
1,79\end{array}$ \\
\hline
\end{tabular}

${ }^{a}$ Bendras drègmės kiekis, esantis poliolyje, PGAD dalelėse ir RPG, buvo perskaičiuotas distiliuoto vandens kiekiui, reikalingam bandinių išpūtimui.

Technologinė bandinių gamybos schema pateikiama 2.4 paveiksle. Skirtingų sudèčių mišiniai buvo ruošiami skirtingose 31 talpose, kuriose RPG buvo maišomas su polioliu, katalizatoriais bei paviršiu aktyvinančia medžiaga buitiniu maišytuvu $1 \mathrm{~min} .1800 \mathrm{aps} . / \mathrm{min}$. greičiu. 
Gauti mišiniai padalinti ị 5 lygias dalis kiekvienai sudèčiai. I̦ kiekvieną iš šių dalių pripiltas perskaičiuotas kiekis vandens ir įmaišytas reikiamas termiškai ir chemiškai apdorotų PGAD dalelių kiekis. Gautas komponentas A 1 min. permaišytas 1800 aps./min. greičiu ir ị jị supiltas reikiamas kiekis komponento B. Gautas mišinys buvo maišomas $10 \mathrm{~s}$ ir supilamas ị 400×400×100 mm dydžio formą, kurioje jam leista pūstis $23 \pm 2{ }^{\circ} \mathrm{C}$ temperatūroje. Gauti gaminiai išlaikyti 24 val., išformuoti ir supjaustyti ị nurodomo dydžio bandinius (2.3.3 poskyris).

Gaminio paviršius prieš pjaustant bandinius buvo nupjaunamas. Bandiniai prieš bandymus 24 val. buvo išlaikomi $23 \pm 5{ }^{\circ} \mathrm{C}$ temperatūros ir $50 \pm 5 \%$ santykinès oro drègmès sąlygomis. Visi bandymai atlikti $23 \pm 5^{\circ} \mathrm{C}$ temperatūros ir $50 \pm 5 \%$ santykinès oro drègmès sąlygomis.

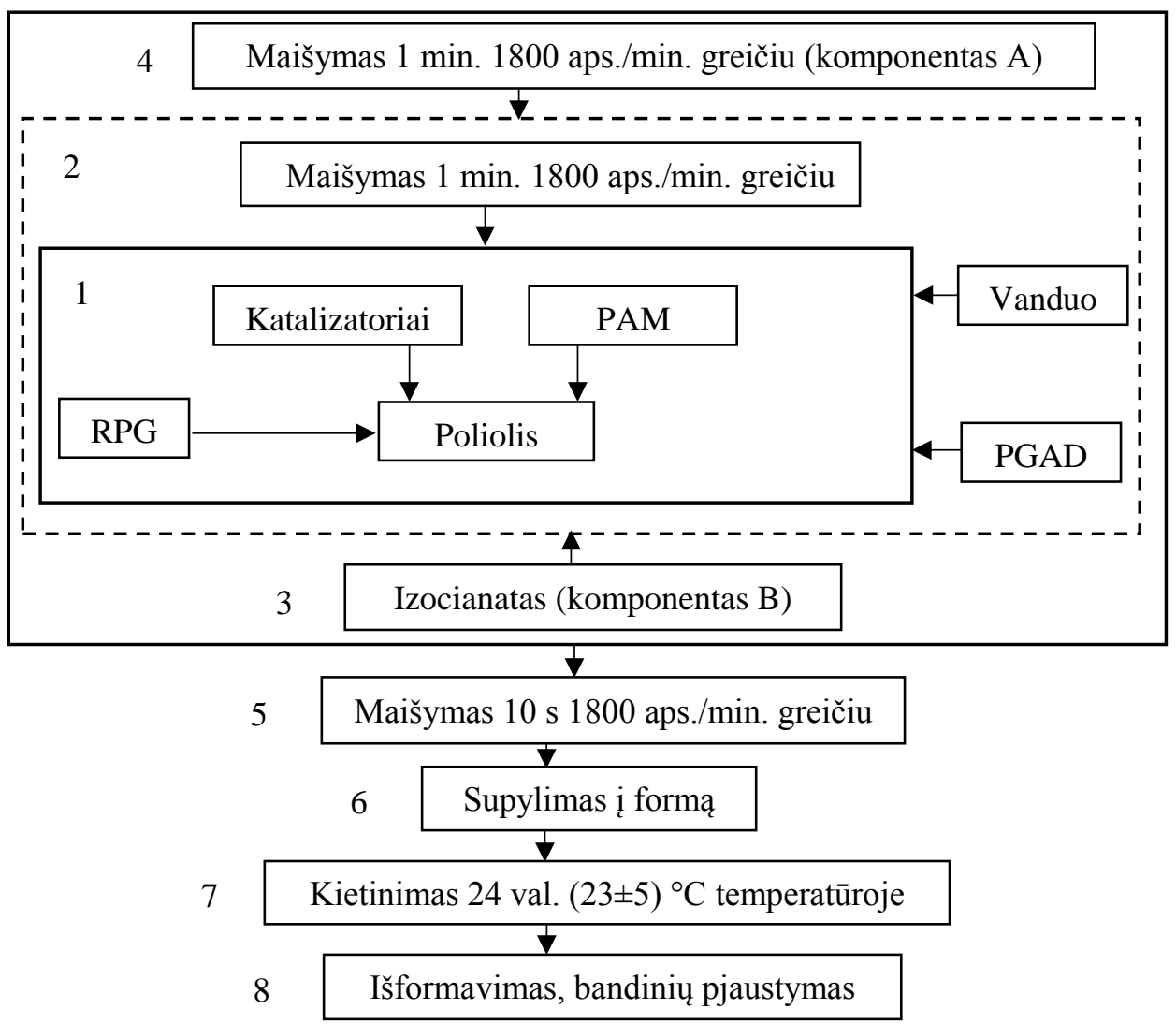

2.4 pav. Propilenglikoliu ir popieriaus gamybos atliekų dumblo dalelemis modifikuotų poliuretano putų bandinių gaybos technologinè schema

Fig. 2.4. Technological scheme of propylene glycol and paper production waste sludge particles modified polyurethane foam specimens 


\subsection{Popieriaus gamybos atliekų dumblo dalelių, poliuretano mišinių ir modifikuotụ poliuretano putų tyrimų metodai}

\subsubsection{Popieriaus gamybos atliekų dumblo dalelių savybių tyrimų metodai}

Titanato jungiamaja medžiaga dengtų ir nedengtų PGAD dalelių struktūros tyrimai atlikti skenuojančiu elektroniniu mikroskopu JEOL JSM - 7600F, kurio skiriamoji geba $-1,5 \mathrm{~nm}$, didinimo geba - nuo 25 iki 1000000 kartų. Tyrimų metu naudota $10 \mathrm{kV}$ ịtampa, dengtų ir nedengtų dalelių didinimas $-\times 5000$. Atstumas iki bandomojo paviršiaus - $11,1 \mathrm{~mm}$. Bendro dalelių organinès ir neorganinès dalių vaizdo didinimas $-\times 2000$. Atstumas iki bandomojo paviršiaus $-11,3 \mathrm{~mm}$. Prieš atliekant tyrimą, dalelès buvo dengiamos plonu aukso sluoksniu vakuumo aplinkoje, garinant aukso elektrodą prietaisu QUORUM Q150R ES. Dalelių padengimo titanato jungiamaja medžiaga efektyvumo tikrinimui papildomai prie skenuojančiojo elektroninio mikroskopo naudotas energijos bangų difrakcijos spektrometras X - Max. Nustatyta lokali cheminè sudètis pagal elektroninio mikroskopo elektronų spindulio sužadintus būdinguosius rentgeno spindulių spektrus.

Bandomuju dalelių organinès dalies procentinio kiekio nustatymas atliktas pagal standarto LST EN 13820 reikalavimus, $105 \pm 5^{\circ} \mathrm{C}$ temperatūroje išlaikant džiovinimo spintoje SNOL $120 / 300$, kurios matavimo ribos $50 \div 300{ }^{\circ} \mathrm{C}$, po tris kiekvienos imties bandinius iki pastovios masès ir $500 \pm 10^{\circ} \mathrm{C}$ temperatūroje išdegant ventiliuojamoje elektros krosnyje SNOL 4/900, kurios matavimo ribos $50 \div 900{ }^{\circ} \mathrm{C}$, tikslumas $10{ }^{\circ} \mathrm{C}$. Organinès dalies struktūros tyrimai atlikti skenuojančiu elektroniniu mikroskopu Helios NanoLab 650, kurio skiriamoji geba - 0,8 nm, didinimo geba - nuo 50 iki 1000000 kartų. Tyrimų metu naudota $1 \mathrm{kV}$ įtampa, didinimas $-\times 2000$, atstumas iki bandomojo paviršiaus $-3 \mathrm{~mm}$. Prieš atliekant tyrimą, dalelès buvo dengiamos plonu anglies sluoksniu vakuumo aplinkoje.

PGAD dalelių kokybinès fazinès sudèties analizei atlikti naudotas rentgeno spindulių difraktometras D8 Advance su $2,4 \mathrm{~kW}$ rentgeno spindulių vamzdžiu ir $\mathrm{Cu}$ anodu. Difrakcijos kampo $2 \theta$ intervalas kito nuo $5^{\circ}$ iki $80^{\circ}$, detektoriaus judejjimo žingsnis $-0,02^{\circ}$. Bandymams naudota ịtampa $-40 \mathrm{kV}$, srovè $-40 \mathrm{~mA}$.

Tiriamosios medžiagos kiekybinė analizė atlikta, naudojant rentgeno fluorescencinès spektroskopijos metodą irrenginiu Axios mAX su $4 \mathrm{~kW}$ rentgeno spindulių vamzdžiu ir Rh anodu. Bandymams dalelès buvo suspaustos i $37 \mathrm{~mm}$ skersmens tabletes.

PGAD daleliu granuliometrinès sudèties nustatymui naudotas lazerinis granuliometras Cilas 1090 LD. Bandymo metu vanduo naudotas kaip dispersinè 
terpè. Dalelių dydis matuotas intervale nuo $0,01 \mu \mathrm{m}$ iki $500 \mu \mathrm{m}$. Dalelių, kurių dydis nuo $500 \mu \mathrm{m}$ iki $629 \mu \mathrm{m}$, kiekis nustatytas $500 \mu \mathrm{m}$ ir $630 \mu \mathrm{m}$ dydžio sietais.

Dalelių drègnis nustatytas analizatoriumi A\&D MX - 50 su $400 \mathrm{~W}$ kaitinimo ir $0,001 \mathrm{~g}$ tikslumo svèrimo sistemomis. Bandinių drėgnis nustatytas $0,01 \%$ tikslumu. Kaitinimo metu naudoti penki $10 \mathrm{~g}$ bandiniai.

Dalelių savitasis paviršius nustatytas Bleino įrenginiu pagal LST EN 196-6 standarto reikalavimus. Vidutinè visų rezultatų vertė gauta išbandžius penkis bandinius.

PGAD daleliu piltinio tankio nustatymui naudota standartinè piltinio tankio nustatymo metodika, pateikta LST EN 1097-3, kuomet iš ne didesnio kaip $5 \mathrm{~cm}$ aukščio į žinomos masės indą samteliu pilamos PGAD dalelès. Perteklius nubraukiamas metaline liniuote, indas pasveriamas $0,01 \mathrm{~g}$ tikslumu. Vidutinei rezultatų vertei gauti atlikti 5 bandymai.

Šilumos laidumo koeficientas nustatytas pagal LST EN 12667 standarto reikalavimus šilumos srauto matuokliu FOX 304, bandymams naudojant $300 \times 300 \times 50 \mathrm{~mm}$ dydžio formą, pagamintą iš lanksčiujų poliuretano putų. Dalelių šilumos laidumo koeficientas nustatytas vidutineje $10^{\circ} \mathrm{C}$ temperatūroje, skirtumas tarp apatinès ir viršutinès plokščiu $-20^{\circ} \mathrm{C}$. Rezultatų patikimumui užtikrinti išbandyti trys bandiniai.

\subsubsection{Formavimo mišinių savybių tyrimų metodai}

Bendrasis poliolio ir RPG arba RGL mišinių funkcionalumas $F_{M}$ apskaičiuotas pagal (2.4) formulę:

$$
F_{M}=\frac{F_{P} \cdot k_{P}+F_{R P G, R G L} \cdot k_{R P G, R G L}}{k_{P}+k_{R P G, R G L}},
$$

čia $k_{P, R P G, R G L}-$ poliolio ir grandinès plètiklių, kurių funkcionalumas atitinkamai $F_{P}, F_{R P G, R G L}$, moliai, mol.

Bendroji poliolio ir RPG arba RGL mišinių molekulinė masė $M_{M}$ apskaičiuota pagal (2.5) formulę:

$$
M_{M}=\frac{M_{P} \cdot k_{P}+M_{R P G, R G L} \cdot k_{R P G, R G L}}{k_{P}+k_{R P G, R G L}},
$$

čia $k_{P, R P G, R G L}$ - poliolio ir grandinès plètiklių, kurių molekulinė masė atitinkamai $M_{P}, M_{R P G, R G L}$, moliai, mol.

Poliolio ir RPG arba RGL mišinių bendrasis hidroksilų skaičius $n_{O H(M)}$ apskaičiuotas pagal (2.6) formulę: 


$$
n_{O H(M)}=\frac{F_{M} \cdot 56100}{M_{M}},
$$

čia $n_{O H(M)}$ - poliolio ir RPG arba RGL mišinio hidroksilu skaičius, mg KOH/g; 56100 - kalio hidroksido ekvivalentinè masè, $\mathrm{mg} / 1,0 \mathrm{~g} ; M_{M}$ - bendroji poliolio ir RPG arba RGL mišinio molekulinè masè, g/mol; $F_{M}$-bendrasis poliolio ir RPG arba RGL mišinio funkcionalumas.

Standžiujų poliuretano putu išpūtimo ir standèjimo reakcijų pusiausvyros užtikrinimui nustatyti tiršteejimo, standèjimo, nelipnumo pradžios laikai bei bandinių aukštis pagal tarptautinị standartą ASTM D7487, naudojant plastikinio puodelio bandymo metodą (2.5 pav.). Tirštéjimo pradžios laikas nustatytas mechaniniu laikmačiu burbuliukų formavimosi pradžios momentu, kuomet pasikeičia mišinio spalva. Standëjimo laikas - stikline lazdele smaigstant besipučiantį formavimo mišinị tol, kol fiksuojamos tąsios polimero gijos.

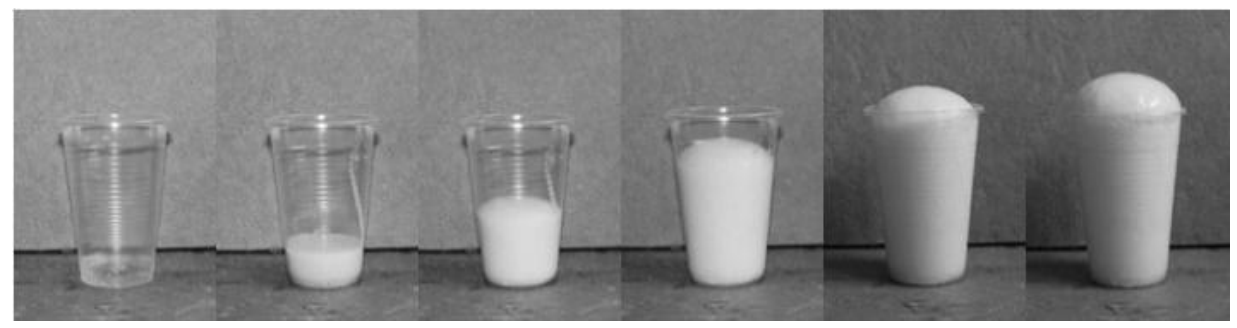

2.5 pav. Standžiujjų poliuretano putu pūtimosi procesas, naudojant standartinị puodelio metodą

Fig. 2.5. Foaming process of rigid polyurethane foam using standard cup test method

Nelipnumo laikas - liečiant putų paviršių tol, kol putos visiškai nebelimpa prie stiklinès lazdelès. Galutinio aukščio nustatymui gauti bandiniai buvo matuojami metaline $1 \mathrm{~mm}$ tikslumo liniuote nuo bandinių apačios iki aukščiausio putų paviršiaus taško. Būdingųjų reakcijos laikų bei bandinių aukščio nustatymui suformuota po 3 kiekvienos imties bandinius.

Standžiųu poliuretano putų, modifikuotų grandinès plètikliais, formavimo mišinių su izocianatu reakcijos temperatūra nustatyta prietaisu Pico TC -08 su K tipo termopora, kurios tikslumas $0,01{ }^{\circ} \mathrm{C}$.

Titanato jungiamaja medžiaga padengtų PGAD dalelių kiekio poveikio formavimo mišinių dinaminei klampai nustatymui naudotas viskozimetras $\mathrm{SV}-10$, kurio tikslumas $0,01 \mathrm{mPa} \cdot \mathrm{s}$ ir matavimo geba iki $1200 \mathrm{mPa} \cdot \mathrm{s}$. Parametro vidutine vertè nustatyta išbandžius po 3 kiekvienos imties bandinius. 


\subsubsection{Nemodifikuotụ ir propilenglikoliu bei popieriaus gamybos atliekų dumblo dalelèmis modifikuotụ poliuretano putu tyrimų metodai}

Bandiniu ilgis ir plotis nustatyti pagal LST EN 12085, tankis-pagal LST EN 1602 standartų reikalavimus dešimčiai (vandens ir grandinès plètiklių poveikio tyrimams) ir aštuoniems (RPG ir PGAD dalelių poveikio tyrimams) kiekvienos imties bandinių, kurių dydis $50 \times 50 \times 50 \mathrm{~mm}$.

Šilumos laidumo koeficientas nustatytas, remiantis LST EN 12667 standarto reikalavimais vieno bandinio simetrinės konfigūracijos horizontalaus tipo šilumos srauto matuoklio įrenginiu FOX 304 su aktyvia bandinių kraštų apsauga, esant šilumos srauto krypčiai iš apačios i viršų. Irenginio matavimo ribos - nuo $0,01 \mathrm{~W} /(\mathrm{m} \cdot \mathrm{K})$ iki $0,50 \mathrm{~W} /(\mathrm{m} \cdot \mathrm{K})$, matavimų tikslumas $-1 \%$. Bandinių, kurių dydis $300 \times 300 \times 50 \mathrm{~mm}$, šilumos laidumo koeficientas nustatytas vidutineje $10^{\circ} \mathrm{C}$ temperatūroje, skirtumas tarp apatinès ir viršutinès plokščiu bandymų metu buvo $20{ }^{\circ} \mathrm{C}$. Rezultatų patikimumo užtikrinimui išbandyta po tris kiekvienos imties bandinius.

Bandinių, kurių standartinis dydis, atsižvengiant ị gaminių storį, $(50 \times 50 \times \mathrm{d}$, kai $\mathrm{d} \leq 50 \mathrm{~mm}$ ) $\mathrm{mm}$, gniuždymo ir tempimo stipriai nustatyti atitinkamai pagal standartu LST EN 826 ir LST EN 1607 reikalavimus ịrenginiu H10KS Hounsfield, fiksuojant įtempių ir deformacijos kreives programine įranga QMat Professional. Bandinių apkrovimo kryptis gniuždymo metu buvo statmenai putų pūtimosi krypčiai. Prieš tempimo bandymą bandiniai buvo klijuojami prie $100 \times 50$ mm dydžio metalinių plokštelių epoksidiniais klijais ir išlaikomi 24 val. $23 \pm 5{ }^{\circ} \mathrm{C}$ temperatūros ir $50 \pm 5 \%$ santykinès oro drègmès aplinkoje. Vidutinei gniuždymo ir tempimo stiprių vertei gauti išbandyta po tris (grandinès plètiklių poveikio gniuždymo stipriui tyrimams) ir aštuonis (RPG ir PGAD dalelių poveikio gniuždymo ir tempimo stipriams tyrimams) kiekvienos imties bandinių.

Siekiant išsiaiškinti grandinès plètiklių ir PGAD dalelių poveiki gaminių drègminèms savybėms, gaminių ilgalaikè vandens sugertis visiškai jame panardinus nustatyta bandiniams, kurių dydis $50 \times 50 \times 50 \mathrm{~mm}$, pagal LST EN $120872 \mathrm{~A}$ metodą po 28 parų, kuomet ištrauktas iš vandens bandinys $10 \pm 0,5$ min buvo drenuotas $45^{\circ} \mathrm{kampu}$ ir pasvertas $0,01 \mathrm{~g}$ tikslumu. $100 \times 100 \times 50 \mathrm{~mm}$ dydžio poliuretano putų bandinių pralaidumas vandens garui nustatytas pagal LST EN 12086 standarto reikalavimus. Bandinių ir plastikinių lèkštelių su druska sąranka buvo išlaikoma $23 \pm 1{ }^{\circ} \mathrm{C}$ temperatūros ir $50 \pm 2 \%$ drègmès oro aplinkoje. Sąrankoje buvo palaikoma $95 \pm 2 \%$ drègmé, naudojant kalio nitrato tirpalą.

Pradinè susitrauktis buvo vertinama $400 \times 400 \times 50 \mathrm{~mm}$ dydžio gaminiams po 0,5 val. ir 1 dienos po gamybos, skaičiuojant pokyčius ilgio, pločio ir storio kryptimis pagal (2.7) formulę: 


$$
\Delta \varepsilon=\frac{b_{1}-b_{2}}{b_{1}} \cdot 100
$$

čia $\Delta \varepsilon$-pradinė gaminio susitrauktis ilgio, pločio ir storio kryptimis, $\% ; b_{1}-$ gaminio ilgis, plotis ir storis po 0,5 val. po gamybos, $\mathrm{mm} ; b_{2}-$ gaminio ilgis, plotis ir storis po 1 dienos po gamybos, mm. Vidutinès pradinès susitraukties įvertinimui išbandyta po tris kiekvienos imties gaminius.

Papildomam gaminių patvarumo įvertinimui standžiosioms poliuretano putoms atliktas matmenų stabilumo padidintos temperatūros ir drègmès sąlygomis bandymas pagal LST EN 1604 numatytą metodiką. Bandiniai $70 \pm 2{ }^{\circ} \mathrm{C}$ temperatūroje ir $90 \pm 5 \%$ santykinèje drègmèje 48 val. buvo išlaikomi klimatinëje kameroje Feutron 3522/51, kurios temperatūros matavimo ribos $-30 \div 100{ }^{\circ} \mathrm{C}$ ir tikslumas $0,2{ }^{\circ} \mathrm{C}$, drégnio matavimo ribos $10 \div 100 \%$ ir tikslumas $5 \%$. Kiekvienai imčiai išbandyta po tris $100 \times 100 \times 50 \mathrm{~mm}$ dydžio bandinius.

Poliuretano putų kietujų ir minkštujų segmentų procentiniai kiekiai apskaičiuoti pagal (2.8)-(2.10) formules:

$$
\begin{gathered}
K S_{\text {Uretano }}=\frac{k_{R G P, R G L} \cdot\left(M_{R P G, R G L}+M_{M D I}\right)}{W_{V i s o}-k_{\mathrm{H}_{2} \mathrm{O}} \cdot M_{\mathrm{CO}_{2}}} \cdot 100 ; \\
K S_{\text {Urej } \mathrm{ja}}=\frac{k_{\mathrm{H}_{2} \mathrm{O}} \cdot\left(M_{\mathrm{H}_{2} \mathrm{O}}+2 \cdot M_{M D I}-M_{\mathrm{CO}_{2}}\right)}{W_{\text {Viso }}-k_{\mathrm{H}_{2} \mathrm{O}} \cdot M_{\mathrm{CO}_{2}}} \cdot 100 ; \\
M S_{P}=\frac{W_{P}}{W_{V i s o}-k_{\mathrm{H}_{2} \mathrm{O}} \cdot M_{C O_{2}}} \cdot 100
\end{gathered}
$$

čia $K S_{\text {Uretano }}, K S_{\text {Uréja }}$ - apskaičiuotasis uretano ir urejja kietujų segmentų kiekis, \%; $M S_{P}$ - apskaičiuotasis poliolio minkštujų segmentų kiekis, \%; $k_{R P G, R G L}$, $k_{\mathrm{H}_{2} \mathrm{O}}-\mathrm{RPG}, \mathrm{RGL}$ ir vandens moliai, mol; $W_{P}, W_{V s o}$ - poliolio ir visų medžiagų masès, g, $M_{R P G, R G L}, M_{C_{2}}, M_{\mathrm{H}_{2} \mathrm{O}}, M_{M D I}-\mathrm{RPG}, \mathrm{RGL}, \mathrm{CO}_{2}$, vandens ir skysto izocianato molekulinès masès, $\mathrm{g} / \mathrm{mol}$.

PGAD dalelių poveikio modifikuotų poliuretano putų aukštose temperatūrose ivertinimui atliktos termogravimetrinè ir diferencinè terminè analizès atmosferos oro aplinkoje bandiniams, kurių masè kito nuo $5 \mathrm{~g}$ iki $10 \mathrm{~g}$, irenginiu Linseis STA $\mathrm{PT}-1600$ temperatūrų intervale nuo $25^{\circ} \mathrm{C}$ iki $900^{\circ} \mathrm{C}$. Temperatūra matuota $\mathrm{K}$ tipo termopora, bandymams naudoti platinos tigliai. Temperatūros kèlimo greitis $10{ }^{\circ} \mathrm{C} / \mathrm{min}$. 
Užsidegamumo ịvertinimui gaminiai buvo veikiami atvira liepsna pagal standarto LST EN ISO 11925-2 reikalavimus trims kiekvienos imties bandiniams, kurių dydis $200 \times 90 \times 50 \mathrm{~mm}$. Bandiniai buvo veikiami $45^{\circ}$ nukreipta atvira liepsna 15 s. Pašalinus liepsnos šaltinį, bandiniai palikti liepsnoti papildomai 5 s. Apanglejusios dalies aukštis matuotas $0,5 \mathrm{~m}$ ilgio metaline $0,5 \mathrm{~mm}$ tikslumo liniuote, laikas, kuomet liepsna pasiekia $150 \mathrm{~mm}$ aukštį, bei savaiminio užgesimo laikas matuoti skaitmeniniu laikmačiu RECALL JS 6619. Išmatuoti laikai suapvalinti sekundès tikslumu.

Poliuretano putų reakcija ị ugnị nustatyta pagal ISO 5660-1 standarto reikalavimus FTT Dual kūginiu kalorimetru. Pagrindiniai parametrai bandymo metu: šilumos srautas $-35 \mathrm{~kW} / \mathrm{m}^{2}$, bandomojo paviršiaus plotas $-88,4 \mathrm{~cm}^{2}$, bandymo laikas - $325 \mathrm{~s}$. Išbandyta po keturis kiekvienos imties bandinius. Bandymo metu registruoti šilumos išsiskyrimo greitis (HRR), maksimalus šilumos išsiskyrimo greitis (pHRR), visuminis šilumos išsiskyrimas (THR), visuminis dūmų išsiskyrimas (TSR), anglies monoksido $(\mathrm{CO})$ ir anglies dioksido $\left(\mathrm{CO}_{2}\right)$ kiekiai.

PGAD dalelių poveikio RPG modifikuotų standžiụjų poliuretano putų struktūrai nustatymui atlikti tyrimai skenuojančiu elektroniniu mikroskopu JEOL JSM - 7600F, kurio skiriamoji geba 1,5 nm, didinimas - nuo 25 iki 1000000 kartų. Tyrimų metu naudota $4 \mathrm{kV}$ ịtampa, didinimas $-\times 35, \times 50$ ir $\times 200$, atstumas iki bandomojo paviršiaus $10 \mathrm{~mm}$. Mikrostruktūra ir jos parametrai identifikuoti tiriant lygiagretų pūtimosi krypčiai paviršių. Prieš atliekant tyrimą, bandiniai buvo dengiami plonu aukso sluoksniu vakuumo aplinkoje, garinant aukso elektrodą prietaisu QUORUM Q150R ES. Gautų mikrostruktūros nuotraukų pagrindu išmatuotas vidutinis akučių dydis, naudojant programinę įrangą ImageJ. Procentiniam akučių kiekiui apskaičiuoti, atlikti tyrimai pagal standarto LST EN ISO 4590 2 metodo reikalavimus trims kiekvienos imties bandiniams, kurių dydis $100 \times 30 \times 30 \mathrm{~mm}$.

\subsection{Tyrimų rezultatụ matematinis ir statistinis apdorojimas}

Eksperimentinių duomenų analizei atlikti buvo taikomi matematiniai ir statistiniai metodai, naudojant programini paketą STATISTICA. Optimaliam kintamujų $X$ ir $Y$ bei $X, Y$ ir $Z$ ryšių nustatymui taikyta netiesinè koreliacija. Tinkamiausiai gautus eksperimentinius rezultatus aprašantis modelis buvo nustatomas, atsižvelgiant ị gautus koreliacijos santykio kvadratus $\eta^{2}$, kurių dydžiai lemia kintamujjų ryšio stiprumą, t. y. kuo minètojo parametro verte arčiau 1, tuo ryšys stipresnis (Sakalauskas 2003). 
Siekiant įvertinti eksperimentinių rezultatų sklaidą abipus regresijos linijos, buvo tikrinamas eksperimentinių rezultatų pasiskirstymas. Esant duomenų pasiskirstymui pagal normalųji skirstinị (disertacijoje nagrinejamų kintamujų skirstinys yra normalusis), nustatomas vidutinis kvadratinis nuokrypis $S_{r}$ ir, be taškinių verčių, apskaičiuojamos galimos klaidų vertès, leidžiančios pereiti prie intervalinio prognozavimo (Harrison 1990; Preston 2000):

$$
Y_{\text {progn }}=Y_{X_{i}} \pm \delta
$$

čia $Y_{p r o g n}$ - minimali arba maksimali prognozuojamoji intervalinè vertė; $Y_{X_{i}}$ - taškinè vertè; $\delta$-galimos klaidos vertè.

$$
\delta=\frac{t_{\alpha} \cdot S_{r}}{\sqrt{n}}
$$

čia $t_{\alpha}$-Stjudento kriterijus, kurio vertè pasirenkama pagal laisvės laipsnių skaičių $f=m-n$, kai tikimybè, esant dvipusiam ir vienpusiam kriterijui, yra $P=0,95 ; n-$ imties dydis.

\subsection{Antrojo skyriaus išvados}

1. Modifikuotų poliuretano putų, pasižyminčių termoizoliacinėms medžiagoms būdingu tariamuoju tankiu, kintančiu $40-50 \mathrm{~kg} / \mathrm{m}^{3}$ ribose, bei norminiais dokumentais apibrèžtu matmenų stabilumu $(\leq 5 \%$ ilgio ir pločio bei $\leq 10 \%$ storio kryptimis), sudèties optimizavimui pasirinkta tirti nuo $1 \mathrm{dpm}$ iki $6 \mathrm{dpm}$ vandens kiekius.

2. Matmenų atžvilgiu stabilių poliuretano putų gamybai pasirinkta naudoti nuo $5 \mathrm{dpm}$ iki $25 \mathrm{dpm}$ grandinès plètiklių. Modifikuotų poliuretano putu gamybai - nuo $10 \mathrm{dpm}$ iki $20 \mathrm{dpm}$ propilenglikolio ir nuo $5 \%$ iki $20 \%$ popieriaus gamybos atliekų dumblo dalelių.

3. Sąveikos tarp termiškai apdorotų popieriaus gamybos atliekų dumblo dalelių ir polimerinès matricos užtikrinimui bei drègminių savybių gerinimui pasirinkta naudoti $1 \%$ nuo užpildo masès titanato jungiamosios medžiagos. 



\section{Propilenglikoliu ir popieriaus gamybos atliekų dumblo dalelèmis modifikuotụ poliuretano putų struktūros ir fizikinių savybių tyrimai}

Pateiktų tyrimų tikslas - sukurti ir ištirti matmenų atžvilgiu stabilias poliuretano putas, susintetintas iš rapsų aliejaus poliolių ir modifikuotas popieriaus gamybos atliekų dumblo dalelèmis.

Šiame skyriuje parinktas racionalus vandens kiekis popieriaus gamybos atliekų dumblo dalelėmis modifikuotų poliuretano putų tyrimams. Nustatyta, kad matmenų atžvilgiu stabilių standžiųjų poliuretano putų gamyboje tikslinga naudoti nuo $10 \mathrm{dpm}$ iki $20 \mathrm{dpm}$ propilenglikolio. Taip pat pateikti propilenglikoliu iš rapsų glicerino ir popieriaus gamybos atliekų dumblo dalelèmis modifikuotu poliuretano putų struktūros, fizikinių, mechaninių, terminių savybių bei degumo charakteristikų tyrimai.

Skyriaus tematika paskelbti 4 autorès straipsniai (Kairytė, Vèjelis 2015), (Kairytè et al. 2016), (Kairytė et al. 2017a) ir (Kairytè et al. 2017b). 


\subsection{Vandens poveikis poliuretano putų fizikinèms savybèms}

Standžiụjų poliuretano putų sudèties parinkimui vandens kiekis nustatytas atsižvelgiant ị gautų gaminių matmenų stabilumą padidintos temperatūros ir drègmès drègmès aplinkoje, pradinę susitrauktị ir tankį.

Tariamasis tankis yra vienas iš pagrindinių ir svarbiausių parametrų, lemiančių galutinio gaminio savybių pastovumą stipruminių savybių ir ilgaamžiškumo atžvilgiu. Atlikti tyrimai parodè, kad poliuretano putų tankis priklauso nuo vandens kiekio. 3.1 paveiksle pavaizduotas poliuretano putų tankio kitimas, keičiant vandens kiekị komponente A nuo 1,0 dpm iki 6,0 dpm žingsniu 0,5 dpm.

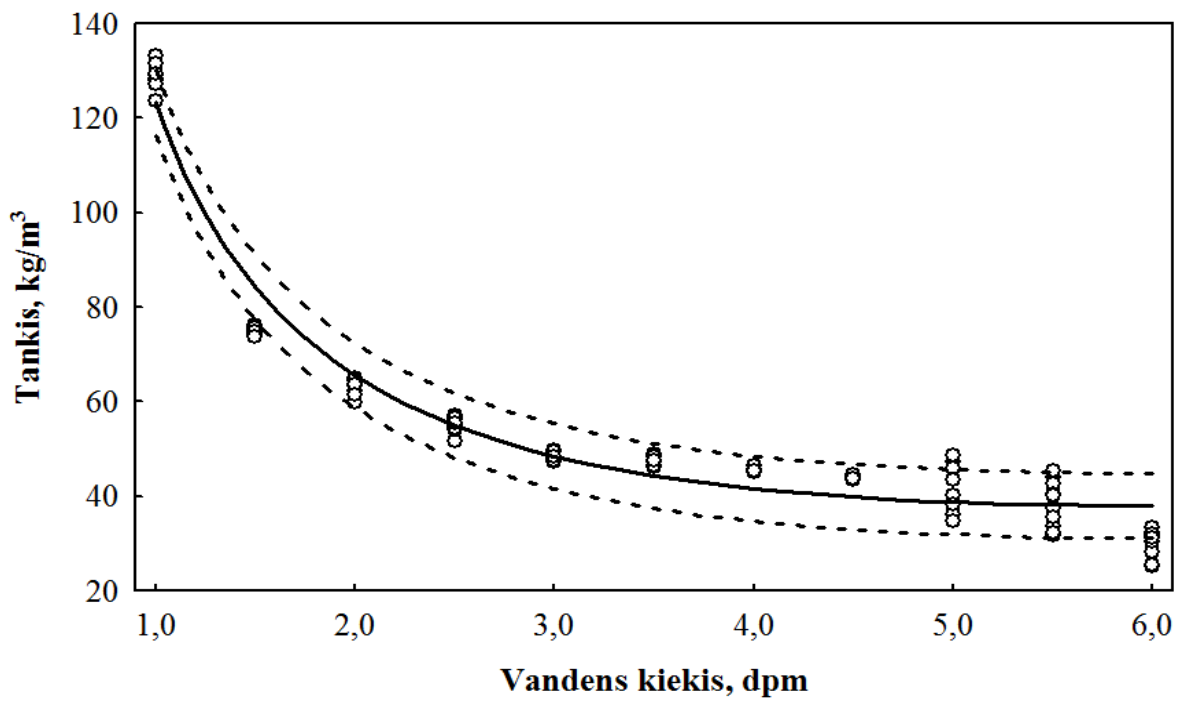

3.1 pav. Standžiujų poliuretano putų tariamojo tankio priklausomybè nuo vandens kiekio: ○-eksperimentiniai duomenys; $(-)$ - regresinè linija (3.1 lygtis); (-----) - prognozuojamoji linija

Fig. 3.1. Dependence of water amount on apparent density of rigid polyurethane foam:

$\circ$ - experimental data; $(-)$ - regression line (Eq. 3.1); (-----) - prediction line

Siekiant ịvertinti šių dviejų faktorių tarpusavio ryšį, atlikta matematinè ir statistinè analizè, kuri leido kiekybiškai ịvertinti tankio pokytị, priklausantị nuo vandens kiekio pokyčio. Vidutinès poliuretano putų tariamojo tankio vertès gali būti aprašytos (3.1) regresine lygtimi su vidutiniu kvadratiniu nuokrypiu $S_{\bar{\rho}_{H_{2} O}}=5,32 \mathrm{~kg} / \mathrm{m}^{3}$ ir koreliacijos santykio kvadratu $\eta_{\bar{\rho}_{H_{2} O}}^{2}=0,958$. 


$$
\bar{\rho}_{\mathrm{H}_{2} \mathrm{O}}=-1,861+3,252 \cdot m_{\mathrm{H}_{2} \mathrm{O}}+\frac{122,9}{m_{\mathrm{H}_{2} \mathrm{O}}},
$$

čia $\bar{\rho}_{\mathrm{H}_{2} \mathrm{O}}$ - vidutinè tariamojo tankio vertè, $\mathrm{kg} / \mathrm{m}^{3} ; m_{\mathrm{H}_{2} \mathrm{O}}$ - vandens kiekis komponente A, dpm. Prognozuojamasis dvipusis rezultatu pasikliautinasis intervalas $\rho_{\text {progn }}=\bar{\rho}_{\mathrm{H}_{2} \mathrm{O}} \pm \delta$, kurių tikimybe் $95 \%$, rezultatų skaičius $n=110$ ir Stjudento kriterijus $t_{\alpha}=1,66$ kai $\alpha=0,05$ (3.1 paveikslas, punktyrinè linija).

Pasiūlytas netiesinès regresijos modelis rodo, kad tariamojo tankio pokyčius 95,8 \% lemia vandens kiekio pokyčiai (nuo 1,0 dpm iki 6,0 dpm), esant 2.2.2 poskyryje paminètiems formavimo sudéčiai ir formavimo bei bandymo sąlygoms. Śi lygtis galioja $30,1-128,7 \mathrm{~kg} / \mathrm{m}^{3}$ tariamojo tankio ribose.

Didinant vandens kiekị nuo 1,0 dpm iki 6,0 dpm, poliuretano putų tariamasis tankis vidutiniškai sumažèjo nuo $128,7 \mathrm{~kg} / \mathrm{m}^{3}$ iki $30,1 \mathrm{~kg} / \mathrm{m}^{3}$, t. y. beveik $76,6 \%$. Vandens ir izocianato reakcijos metu išsiskiria $\mathrm{CO}_{2}$ dujos todèl, didinant vandens kiekị, mišinyje esančiuose ir maišymo metu susidariusiuose oro burbuliukuose didèja $\mathrm{CO}_{2}$ dujų koncentracija. Tai lemia didesnę išpūtimo gebą ir putas, pasižyminčias mažesniu tankiu. Thirumal et al. 2008 atlikti vandens kiekio poveikio galutiniam gaminiui tyrimai parodè panašią tankio kitimo tendenciją, kur, didinant vandens kiekị nuo $0 \mathrm{dpm}$ iki 3,0 dpm, tankis vidutiniškai sumažèjo nuo $116 \mathrm{~kg} / \mathrm{m}^{3}$ iki $42 \mathrm{~kg} / \mathrm{m}^{3}$, t. y. beveik 63,8 \%. Lyginant šių autorių ir šiame poskyryje pateiktų atliktų tyrimų galimas ribas, t. y. nuo 1,0 dpm iki 3,0 dpm, vidutinis tankio sumažejimas, atitinkamai yra lygus 53,3\% ir 62,3\%. Skirtumo atsiradimas gali būti priskiriamas skirtingų žaliavinių medžiagų naudojimui. Taip pat iš 3.1 paveikslo galima pastebėti, jog tankio rezultatų išsibarstymas poliuretano putose, kuriose naudotas vandens kiekis nuo 5,0 dpm iki 6,0 dpm, yra ganètinai didelis. Tai rodo galimą medžiagos nehomogeniškumą.

Tinkamo vandens kiekio parinkimui papildomai atlikti pradinès susitraukties bei matmenu stabilumo padidintos temperatūros ir drègmès aplinkoje tyrimai (3.2 pav.). Galima pastebèti, kad, didejant vandens kiekiui mišinyje nuo 1,0 dpm iki 6,0 dpm, pradinè susitrauktis didèja. Tai reiškia, kad galutinio gaminio struktūra nèra pakankamai standi akytosios struktūros ir gaminị supančios aplinkos slègių skirtumo pusiausvyros užtikrinimui. Pradinè susitrauktis atsiranda dèl greitesnès dujų difuzijos iš akytosios struktūros ị gaminị supančią aplinką, lyginant su oro skverbimosi ị akytają struktūrą greičiu. Tokiu būdu poliuretano putos pereina tris pagrindines stadijas: pirmoji stadija - užuomazgų ir akučių susidarymo procesas, kurio metu atmosferinis ir vidinis slègiai yra vienodi. Antroji stadija - putų standejjimas, kurio metu mišinio molekulinè masė dideja, o akučių formavimosi procesas pasibaigia. Nors putos pasiekia galutinị aukštį, vidiné gaminio temperatūra ir vidinis slègis akutèse didèja. 


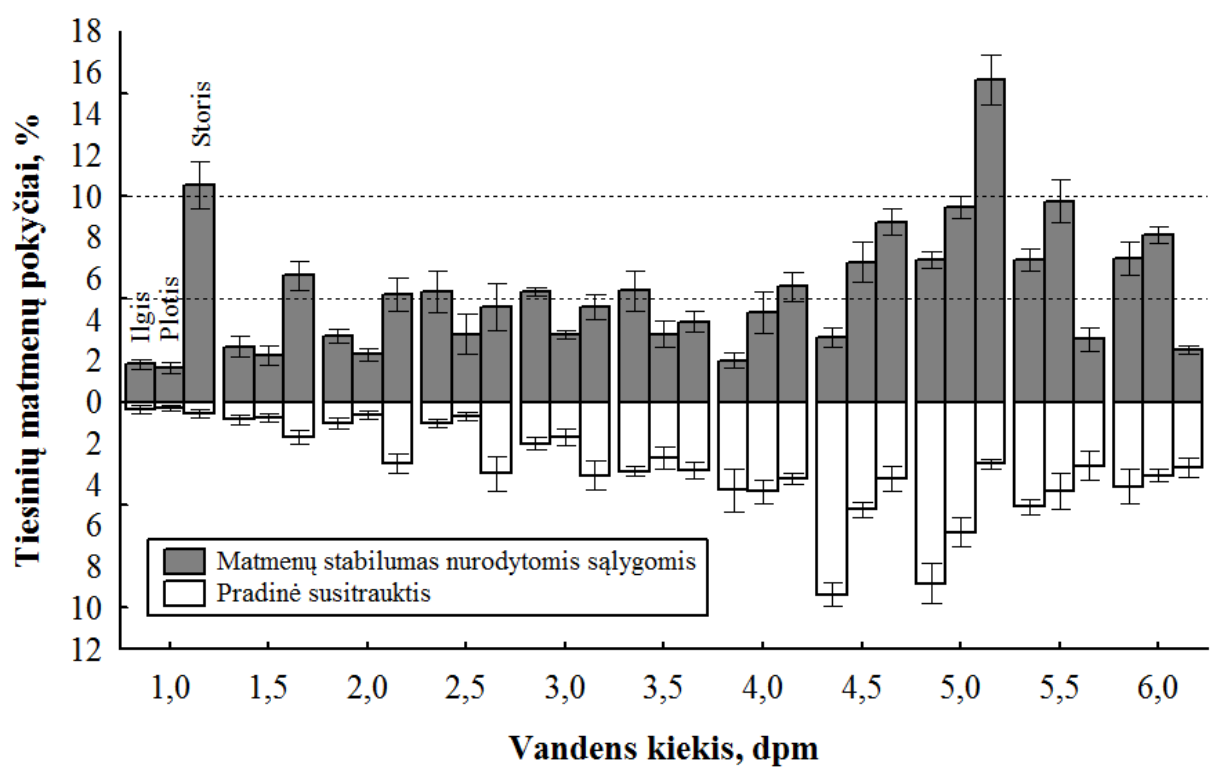

3.2 pav. Standžiujjų poliuretano putu tiesinių matmenų pokyčio priklausomybè nuo vandens kiekio: (-----) - reikalavimai minimaliems ribiniams matmenų pokyčiams ilgio, pločio ir storio kryptimis pagal LST EN 13165

Fig. 3.2. Dependence of water amount on linear dimensions changes of rigid polyurethane foam: (-----) - requirements for minimal dimensional changes limits in the directions of length, width and thickness according to LST EN 13165

Trečioji stadija prasideda tuo metu, kai vidinè gaminio temperatūra ir akutėse susidaręs slègis pradeda mažèti. Tai reiškia, kad, kai vidinis slègis yra mažesnis už atmosferinį slègi, poliuretano putų gaminiuose pasireiškia pradiniai susitraukimai. Šių susitraukimų intensyvumas ir dydis priklauso nuo formavimo mišinyje naudojamo vandens kiekio bei akytosios struktūros pobūdžio (uždaraporè ar atviraporè). Vandens kiekio didejjimas lemia poliuretano putų struktūrą, pasižyminčią didesnėmis uždaromis akutėmis bei plonesnèmis sienelėmis tarp jų, o tai reiškia, kad $\mathrm{CO}_{2}$ dujų difuzija per plonesnes sieneles yra intensyvesnè, o galutinio gaminio susitraukimai didesni.

Kintant temperatūrai, visos medžiagos daugiau ar mažiau plečiasi arba traukiasi. 3.2 paveiksle pateiktus rezultatus būtų galima suskirstyti ị tris pagrindines zonas: nuo 1,0 dpm iki 3,0 dpm, nuo 3,5 dpm iki 5,0 dpm ir nuo 5,5 dpm iki $6,0 \mathrm{dpm}$. Atlikti matmenų stabilumo padidintos temperatūros ir drégmės sąlygomis tyrimai rodo, kad gaminiuose, kuriu gamyboje naudotas vandens kiekis kinta nuo 1,0 dpm iki 3,0 dpm, pastebimas tiesinių matmenų pokyčio mažejjimas. Ga- 
lima teigti, kad didžiausio tankio poliuretano putos turi pakankamai standžią, storesnèmis sienelèmis pasižyminčią akytają struktūrą, kuri suvaržo $\mathrm{CO}_{2}$ dujų skverbimąsi ị aplinką, tai lemia mažą pradinę susitrauktị, tačiau akutėse likusios dujos, veikiamos didesne nei aplinkos temperatūra matmenų stabilumo bandymo metu, ardydamos struktūrą, šalinasi iš gaminio sukeldamos neigiamus matmenų pokyčius, t. y. 0,4\% pradinę susitrauktị ir papildomai 10,6\% storio pokytị matmenų stabilumo bandymo metu gaminiams, kuriuose naudotas vandens kiekis buvo 1,0 dpm. Visiškai priešinga tendencija pastebima gaminiuose, kuriuose naudotas vandens kiekis kinta nuo 3,5 dpm iki 5,0 dpm. Tai paaiškinama tuo, kad mažinant gaminio tankị reikalingas didesnis vandens kiekis. Todèl struktūroje esančių akučių sienelès plonejja, $\mathrm{CO}_{2}$ dujų difuzijos greitis ir jų sukeliami tiesinių matmenų pokyčiai tiek po gamybos, tiek bandymo metu intensyvèja.

Intervale nuo 5,5 dpm iki 6,0 dpm pastebimas matmenų pokyčio mažejjimas. Kai poliuretano putų gamyboje naudojamas mažas kiekis vandens, kaip šiuo atveju 5,0 dpm ir mažiau, izocianato kiekis mišinyje yra ganètinai mažas suderinamumo tarp šių dviejų komponentų užtikrinimui, tolygiam išmaišymui ir tinkamam reakcijos pradžios laiko užtikrinimui. 3.1 lentelèje pateikta būdingụjų poliuretano putų pūtimosi laikų bei struktūrinių parametrų kitimo tendencijos priklausomai nuo vandens kiekio mišinyje.

Poliuretano putų mišinių reaktyvumo sumažèjimas reakcijos, standèjimo pradžių bei nelipnumo laikų atžvilgiu yra paaiškinamas didëjančiu bendru vandens ir poliolio mišinio hidroksilų skaičiumi, kurio skaitinès vertès didejjimą lemia nuo 1,0 dpm iki 6,0 dpm vandens kiekio didinimas. Esant 6,0 dpm vandens, reakcijos pradžios laikas padidèjo $96,3 \%$, standejjimo pradžios laikas $-52,7 \%$, nelipnumo laikas - 41,1 \%, lyginant su mišiniais, kuriuose naudotas 1,0 dpm vandens. Vandens kiekis taip pat sąlygoja akučių dydị, t. y. kuo mišinyje vandens daugiau, tuo didesné poliuretano putų išsipūtimo geba ir tuo didesnis vidutinis akučių dydis. Šis parametras, didejjant vandens kiekiui nuo minimalaus iki maksimalaus, padidejo $476 \%$. Kuo daugiau vandens mišinyje, tuo didesnis izocianato kiekis reikalingas visoms - $\mathrm{OH}$ grupèms sureaguoti. Ši medžiaga yra hidrofobinè, todèl, didinant jos ir vandens kiekius, nebèra užtikrinamas pakankamas šių dviejų medžiagų suderinamumas, tą rodo $26 \mathrm{~s}$ uždelsta reakcijos pradžia, lyginant mišinius su $1,0 \mathrm{dpm}$ ir 6,0 dpm vandens.

Tai reiškia, kad polimero formavimosi reakcijos greitis yra mažesnis nei pūtimosi greitis. Pasibaigus standèjimo reakcijai, polimerinis karkasas nebèra pakankamai tvirtas išlaikyti tolesnị akučių augimą, todèl stebima dalinè akučių destrukcija, kurios rezultatas - atvirų akučių kiekio didèjimas. Susidarius daliai atvirų akučių, $\mathrm{CO}_{2}$ dujos šalinasi iš polimerinès matricos neardydamos gaminio struktūros. Tokiu būdu sumažinama pradiné susitrauktis ir matmenų pokyčiai didesnejje nei aplinkos temperatūroje. 
3.1 lentelè. Būdingieji poliuretano putų pūtimosi laikai ir struktūriniai parametrai

Table 3.1. Characteristic foaming times and structural parameters of polyurethane foam

\begin{tabular}{|c|c|c|c|c|c|}
\hline \multirow{2}{*}{$\begin{array}{c}\text { Vandens } \\
\text { kiekis, } \\
\text { dpm }\end{array}$} & $\begin{array}{c}\text { Reakcijos } \\
\text { pradžios } \\
\text { laikas, s }\end{array}$ & $\begin{array}{c}\text { Standejimo } \\
\text { pradžios } \\
\text { laikas, s }\end{array}$ & $\begin{array}{c}\text { Nelipnumo } \\
\text { laikas, s }\end{array}$ & $\begin{array}{c}\text { Akučių } \\
\text { dydis, mm }\end{array}$ & $\begin{array}{c}\text { Uždarų } \\
\text { akučių } \\
\text { kiekis, \% }\end{array}$ \\
\hline 1,0 & $27 \pm 2$ & $91 \pm 2$ & $190 \pm 4$ & $0,125 \pm 0,03$ & $90,2 \pm 3,2$ \\
\hline 1,5 & $28 \pm 1$ & $98 \pm 3$ & $198 \pm 2$ & $0,130 \pm 0,04$ & $89,3 \pm 2,8$ \\
\hline 2,0 & $31 \pm 3$ & $98 \pm 1$ & $200 \pm 3$ & $0,132 \pm 0,05$ & $89,0 \pm 4,1$ \\
\hline 2,5 & $35 \pm 3$ & $99 \pm 2$ & $210 \pm 4$ & $0,145 \pm 0,03$ & $89,1 \pm 3,6$ \\
\hline 3,0 & $37 \pm 4$ & $102 \pm 4$ & $215 \pm 3$ & $0,152 \pm 0,02$ & $88,0 \pm 4,7$ \\
\hline 3,5 & $40 \pm 3$ & $114 \pm 4$ & $231 \pm 1$ & $0,201 \pm 0,04$ & $87,4 \pm 2,6$ \\
\hline 4,0 & $44 \pm 2$ & $118 \pm 2$ & $235 \pm 2$ & $0,264 \pm 0,03$ & $88,2 \pm 1,8$ \\
\hline 4,5 & $49 \pm 2$ & $124 \pm 3$ & $239 \pm 3$ & $0,320 \pm 0,06$ & $88,6 \pm 4,0$ \\
\hline 5,0 & $51 \pm 4$ & $131 \pm 3$ & $254 \pm 2$ & $0,476 \pm 0,05$ & $87,4 \pm 3,7$ \\
\hline 5,5 & $51 \pm 4$ & $134 \pm 3$ & $261 \pm 2$ & $0,558 \pm 0,06$ & $74,2 \pm 2,4$ \\
\hline 6,0 & $53 \pm 2$ & $139 \pm 2$ & $268 \pm 3$ & $0,720 \pm 0,06$ & $70,5 \pm 2,1$ \\
\hline
\end{tabular}

İvertinus gautus tankio bei matmenų pokyčių rezultatus, tinkamiausias tolesniems bandymams vandens kiekis yra 3,0 dpm. Tai ribinė vandens kiekio vertė, kuomet maksimalus matmenų pokytis neviršija leistinųų, atitinkamai, $\leq 5 \%$ ilgio ir pločio kryptimis bei $\leq 10 \%$ storio kryptimi pagal gamyklinėms standžiosioms poliuretano putoms keliamus reikalavimus aprašantị standartą LST EN 13165, o tariamasis tankis $\left(\sim 48 \mathrm{~kg} / \mathrm{m}^{3}\right)$ yra tinkamas termoizoliacinèms poliuretano putoms, naudojamoms pastatų atitvarų šilumos izoliavimui.

\subsection{Grandinès plètiklių poveikis poliuretano putų fizikinèms ir mechaninėms savybèms}

Nors vandeniu putintų standžiųjų poliuretano putų matmenų stabilumas padidintos temperatūros ir drégmès sąlygomis atitinka ribinius standarto LST EN 13165 reikalavimus, tačiau dèl didelès pradinès susitraukties tokie gaminiai nebegali būti naudojami pastatų atitvarų šilumos izoliacijos sluoksnio gamybai. Šios problemos sprendimui ir galutinio gaminio savybių tyrimams buvo pasirinkti RPG ir RGL, kurių kiekiai kinta nuo 0 dpm iki $25 \mathrm{dpm}$.

Poliuretano putų mišinio reakcijos kinetika labiausiai priklauso nuo išpūtimo ir standẻjimo reakcijų greičio, kita vertus, pačių gaminių savybès priklauso nuo pagrindinio komponento - poliolio funkcinių grupių bei hidroksilų skaičiaus. Šios ir kitos pagrindinès mišinių, kuriuose dalis poliolio pakeičiama grandinès plètikliais, atitinkamai RPG ir RGL, charakteristikos pateikiamos 3.2 ir 3.3 lentelèse. 
3.2 lentelè. Poliolio su propilenglikoliu mišinių parametrai

Table 3.2. Parameters of polyol and propylene glycol mixtures

\begin{tabular}{|l|c|c|c|c|c|}
\hline \multirow{2}{*}{ Parametras } & \multicolumn{5}{|c|}{ Poliolis, dpm } \\
\cline { 2 - 6 } & 95 & 90 & 85 & 80 & 75 \\
\cline { 2 - 6 } & 5 & 10 & 15 & 20 & 25 \\
\cline { 2 - 6 } & 580,6 & 438,1 & 495,7 & 553,3 & 610,9 \\
\hline $\begin{array}{l}\text { Apskaičiuotasis mišinio hidrok- } \\
\text { silų skaičius, mg KOH/g }\end{array}$ & 2,67 & 2,63 & 2,60 & 2,56 & 2,53 \\
\hline $\begin{array}{l}\text { Apskaičiuotasis mišinio funkciniu } \\
\text { grupių skaičius, b. d. }\end{array}$ & $\begin{array}{l}325,7 \\
\pm 5,94\end{array}$ & $\begin{array}{l}324,2 \\
\pm 5,63\end{array}$ & $\begin{array}{c}323,9 \\
\pm 5,31\end{array}$ & $\begin{array}{c}322,8 \\
\pm 5,00\end{array}$ & $\begin{array}{l}321,5 \\
\pm 4,69\end{array}$ \\
\hline $\begin{array}{l}\text { Dinaminè mišinio klampa } 25^{\circ} \mathrm{C} \\
\text { temperatūroje, } \mathrm{m} \cdot \mathrm{Pa}\end{array}$ & \multicolumn{5}{|c|}{$\mathrm{dpm}$} \\
\hline
\end{tabular}

3.3 lentelè. Poliolio su glicerinu mišinių parametrai

Table 3.3. Parameters of polyol and glycerine mixtures

\begin{tabular}{|l|c|c|c|c|c|}
\hline \multirow{2}{*}{ Parametras } & \multicolumn{5}{|c|}{ Poliolis, dpm } \\
\cline { 2 - 6 } & 95 & 90 & 85 & 80 & 75 \\
\cline { 2 - 6 } & \multicolumn{5}{|c|}{ RGL, dpm } \\
\cline { 2 - 6 } & 5 & 10 & 15 & 20 & 25 \\
\hline $\begin{array}{l}\text { Apskaičiuotasis mišinio hidrok- } \\
\text { silų skaičius, mg KOH/g }\end{array}$ & 396,9 & 470,7 & 544,6 & 618,4 & 692,3 \\
\hline $\begin{array}{l}\text { Apskaičiuotasis mišinio funkciniu } \\
\text { grupių skaičius, b. d. }\end{array}$ & 2,72 & 2,73 & 2,75 & 2,76 & 2,78 \\
\hline $\begin{array}{l}\text { Dinaminè mišinio klampa } 25^{\circ} \mathrm{C} \\
\text { temperatūroje, } \mathrm{m} \cdot \mathrm{Pa}\end{array}$ & $\begin{array}{c}337,3 \\
\pm 5,54\end{array}$ & $\begin{array}{c}348,6 \\
\pm 5,23\end{array}$ & $\begin{array}{c}354,9 \\
\pm 5,13\end{array}$ & $\begin{array}{c}368,2 \\
\pm 4,89\end{array}$ & $\begin{array}{c}386,5 \\
\pm 4,58\end{array}$ \\
\hline
\end{tabular}

3.3. paveiksle pateikiama poliuretano putų mišinių, modifikuotų RPG ir RGL polioliais, būdingujų reakcijos laikų kinetika. Galima pastebèti, kad poliolio-RPG ir poliolio-RGL mišinių reaktyvumo pobūdis yra visiškai skirtingas. Tirštėjimo laiko didejjimas RPG ir RGL modifikuotuose mišiniuose aiškinamas egzistuojančiomis antrinių hidroksilų grupėmis, kurios yra mažiau reaktyvios nei pirminès, ir, lyginant su kontrolinèmis poliuretano putomis, padidejjusiomis, atitinkamai nuo $17,8 \%$ iki $89,1 \%$ (poliolio-RPG sudetyse) ir nuo $22,9 \%$ iki $114 \%$ (poliolio-RGL sudètyse) hidroksilo vertėmis (3.2 ir 3.3 lentelès). Tačiau galima pastebèti, jog, didinant RPG kiekị nuo 5 dpm iki $25 \mathrm{dpm}$, standèjimo ir nelipnumo pradžios laikai sumažeja, atitinkamai nuo $115 \mathrm{~s}$ iki $85 \mathrm{~s}$ ir nuo $210 \mathrm{~s}$ iki $114 \mathrm{~s}$, t. y. $100 \mathrm{~s}$, lyginant su kontrolinėmis poliuretano putomis, kai naudojamas $25 \mathrm{dpm}$ RPG kiekis.

RPG pasižymi mažesne molekuline mase bei klampa nei RGL, todèl šios medžiagos įterpimas ir pasiskirstymas poliolio mišinyje yra paprastesnis, tai ịgalina 
sėkmingą šios medžiagos dalyvavimą standèjimo reakcijoje ir padidina šios reakcijos intensyvumą.

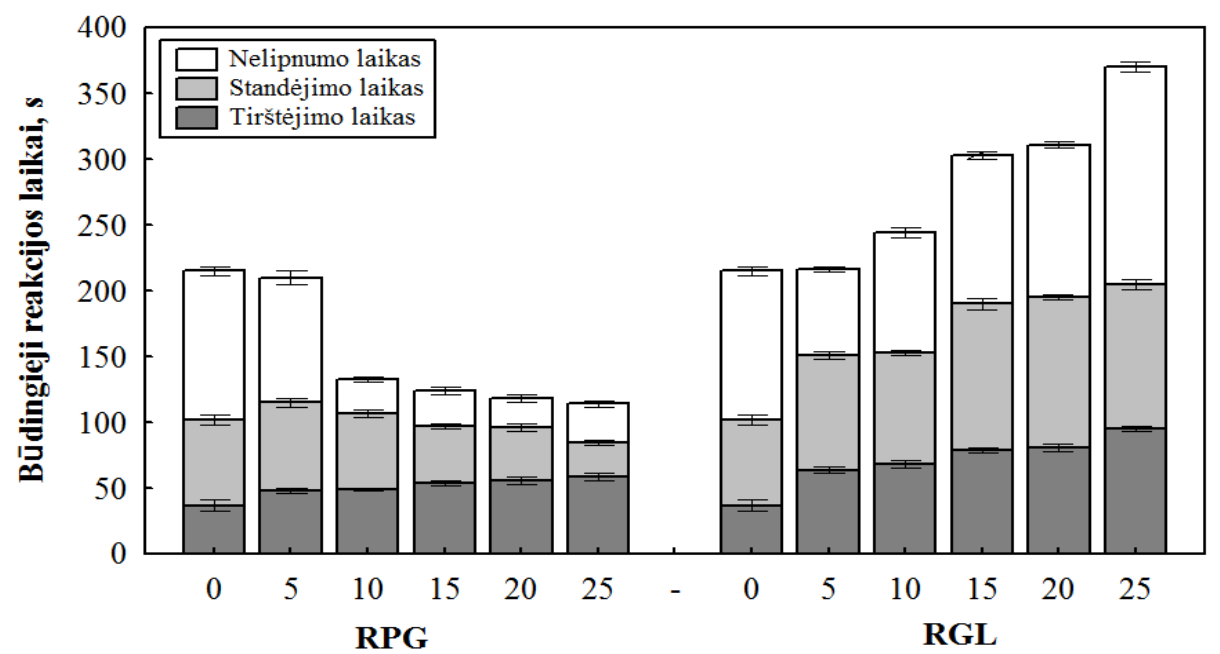

Grandinès plètiklio kiekis, dpm

3.3 pav. Standžiųu poliuretano mišinių, modifikuotų propilenglikoliu ir glicerinu, būdingieji reakcijos laikai

Fig. 3.3. Characteristic foaming times of rigid polyurethane mixtures modified with propylene glycol and glycerine

Nelipnumo laiko mažèjimui RPG atveju ir didèjimui RGL atveju poveikị turi reakcijos temperatūra. Siekiant išvengti duomenų persidengimo, 3.4 paveiksle pateikiama poliolio ir grandinès plètiklių mišinių su mažiausiu ir didžiausiu RPG ir RGL kiekiais, t. y. 5 RPG ir 25 RPG bei 5 RGL bei 25 RGL, reakcijos temperatūra.

Temperatūros kilimą lemia intensyvus -NCO grupių naudojimas, atsirandantis dèl stechiometrinio santykio disbalanso, naudojant izocianato indeksą, lygų 125. Tuo tarpu poliolio-RGL mišinys pasižymi priešinga tendencija didinti laiko tarpą, reikalingą putų struktūros formavimui ir gaminio kietẻjimui.

Taip pat galima pastebèti, kad, didinant RGL kieki nuo $5 \mathrm{dpm}$ iki $25 \mathrm{dpm}$, maksimali reakcijos temperatūra didèja nuo $108^{\circ} \mathrm{C}$ iki $125^{\circ} \mathrm{C} .100-125^{\circ} \mathrm{C}$ temperatūros intervale formuojasi pertekliniai alofanato skersiniai ryšiai tarp uretano jungčiu ir laisvujjų izocianato grupių, kurie užtikrina didelę mišinio klampą, mažinančią poliolio-RGL mišinių standèjimo gebą, tačiau užtikrinančią didesnị poliuretano putų tankị bei stiprumą. 


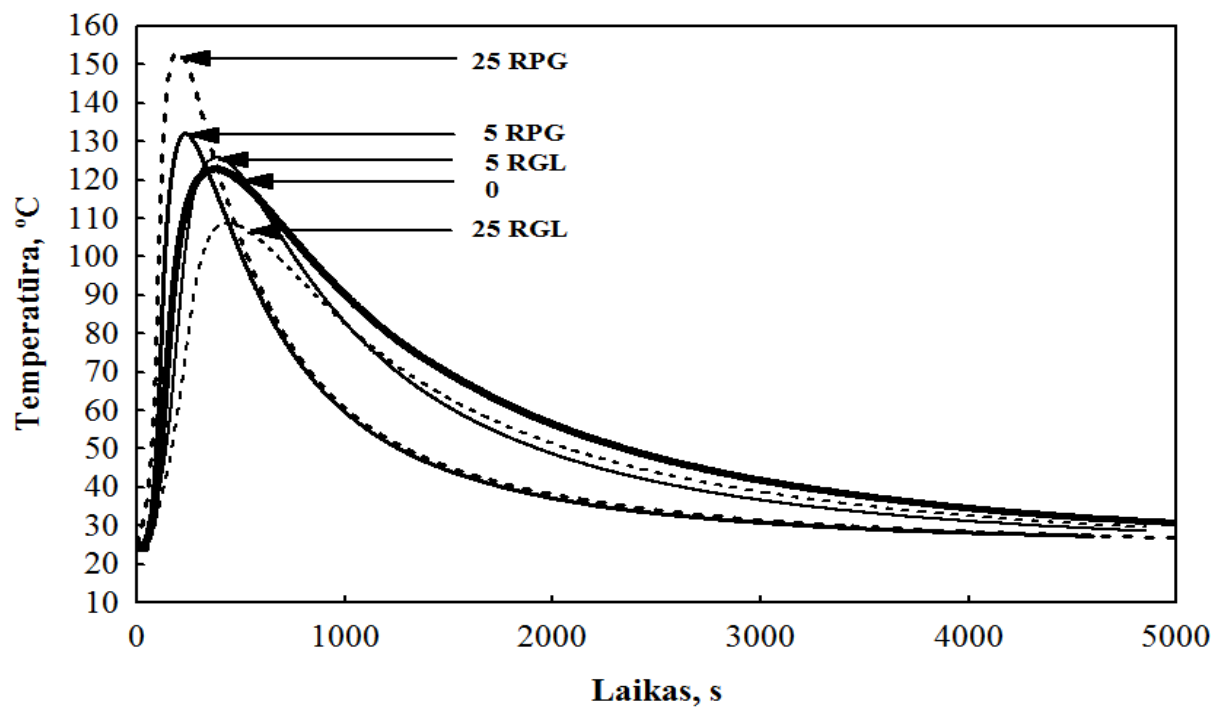

3.4 pav. Temperatūros kitimas propilenglikoliu ir glicerinu modifikuotu standžiųjų poliuretano putų mišiniuose

Fig. 3.4. The change of temperature in propylene and glycerine modified rigid polyurethane foam mixtures

Ši reakcija (3.5 pav.) didesnèje nei $125^{\circ} \mathrm{C}$ temperatūroje yra grịžtamoji, kuomet susiformavusios alofanatinès jungtys virsta uretaninèmis, todèl RPG modifikuotos putos alofanatinių skersinių ryšių susidarymu nepasižymi.

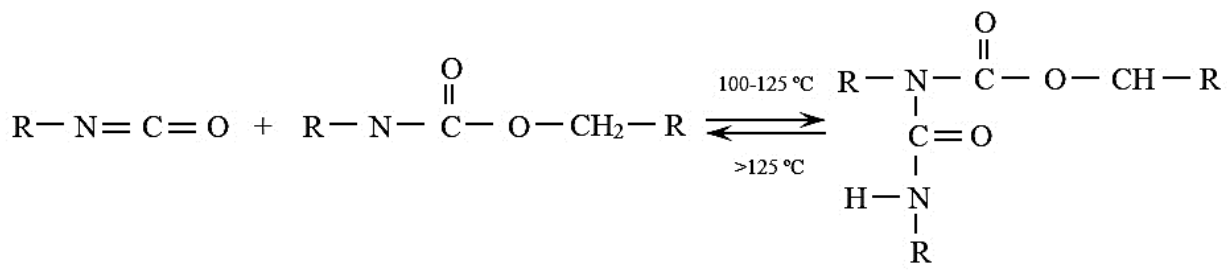

Izocianato grupè Uretano grupè Alofanato grupè

3.5 pav. Alofanato grupès formavimasis (Lapprand et al. 2005)

Fig. 3.5. Allophanate formation (Lapprand et al. 2005)

Putų tiesinių matmenų stabilizavimas yra viena iš svarbiausių užduočių, todèl buvo atlikti modifikuotų standžiųų poliuretano putų matmenų stabilumo $70{ }^{\circ} \mathrm{C}$ 
temperatūros ir $90 \%$ santykinès drègmès aplinkoje ir pradinès susitraukties tyrimai (3.6 pav.). Galima pastebèti, kad tiek RPG, tiek RGL modifikuotų putų pradinè susitrauktis ir matmenų stabilumas $70{ }^{\circ} \mathrm{C}$ temperatūros ir $90 \%$ santykinès drègmès aplinkoje yra mažesni, lyginant su kontrolinèmis poliuretano putomis.
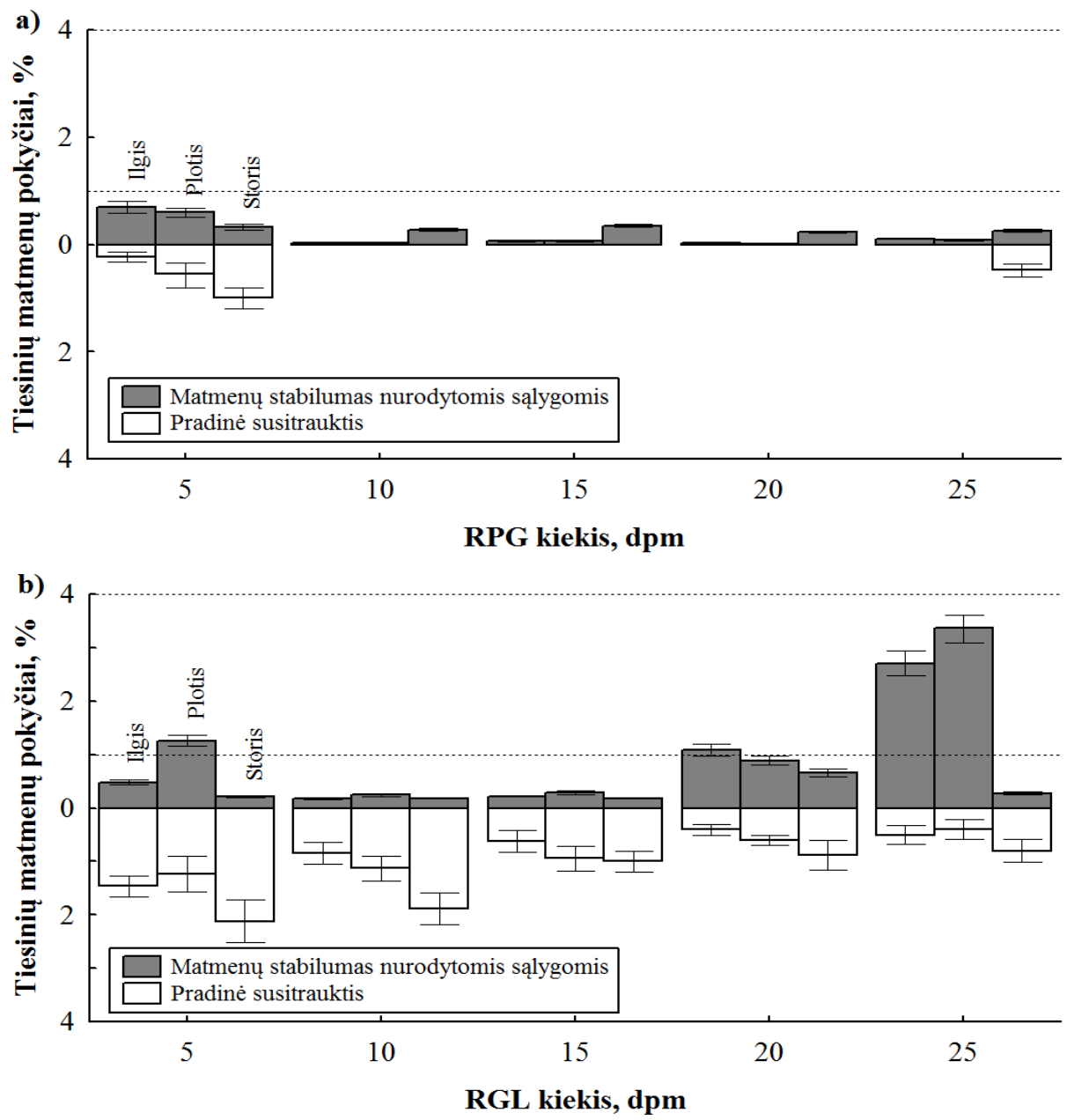

3.6 pav. Standžiujjų poliuretano putų, modifikuotų a) propilenglikoliu ir b) glicerinu, tiesinių matmenų pokyčiai. (------) - maksimalūs ilgio, pločio ir storio reikalavimai pagal LST EN 13165

Fig. 3.6. Changes of linear dimensions for polyurethane foam modified with a) propylene glycol and b) glycerine. (------) - maximum requirements for length, width and thickness according to LST EN 13165 
Iš 3.6 a paveiksle matyti, kad RPG modifikuotos poliuretano putos tenkina maksimalius gaminiui keliamus reikalavimus, t. y. $\leq 1 \%$ ilgiui ir pločiui bei $\leq 4 \%$ storiui. Tiesinių matmenų procentinis pokytis ilgio, pločio ir storio kryptimis RPG modifikuotose poliuretano putose vidutiniškai sumažèjo, atitinkamai nuo $\operatorname{MS}(5,35 / 3,30 / 4,62) \quad$ iki $\quad \mathrm{MS}(0,70 / 0,60 / 0,33) \quad 5 \mathrm{dpm} \quad \mathrm{RPG}$ mišinyje, iki MS(0,03/0,03/0,28) 10 dpm RPG mišinyje, iki MS(0,06/0,06/0,35) 15 dpm RPG mišinyje, iki MS(0,03/0,01/0,23) 20 dpm RPG mišinyje ir iki MS(0,11/0,08/0,26) $25 \mathrm{dpm}$ RPG mišinyje, taip pat RGL modifikuotose putose -iki MS(0,48/1,26/0,21) 5 dpm RGL mišinyje, iki MS(0,17/0,25/0,18) 10 dpm RGL mišinyje, iki MS(0,22/0,29/0,17) 15 dpm RGL mišinyje, iki MS(1,08/0,89/0,66) 20 dpm RGL mišinyje ir iki MS(2,71/3,36/0,28) 25 dpm RGL mišinyje.

Dideli poveikị pradinès susitraukties atveju galutiniam gaminiui daro poliolio mišinio modifikavimas RPG. Lyginant su kontrolinèmis poliuretano putomis, nuo $10 \mathrm{dpm}$ iki $20 \mathrm{dpm}$ RPG modifikuotu putų procentinè pradinè susitrauktis vidutiniškai sumažèjo, atitinkamai nuo MS(2,03/1,72/3,56) iki MS(0/0/0). Gauti rezultatai leidžia daryti išvadą, jog poliolio modifikavimas mažos molekulinès masès medžiagomis (RPG ir RGL) lemia stabilią putų struktūrą dèl sumažejusio procentinio uždarų akučių kiekio (poliolio-RPG mišinys) bei skersinèmis grandimis sustiprintą polimerinę matricą (poliolio-RGL mišinys).

Medžiagos tankis yra pagrindinè savybè, lemianti didžiąją dalị kitų poliuretano putų savybių, ir, kaip kiekvienos savybès, jos skaitinė išraiška gali būti didinama arba mažinama, modifikuojant medžiagos struktūrą. Tariamojo tankio priklausomybė nuo RPG ir RGL kiekių pateikta 3.7 paveiksle
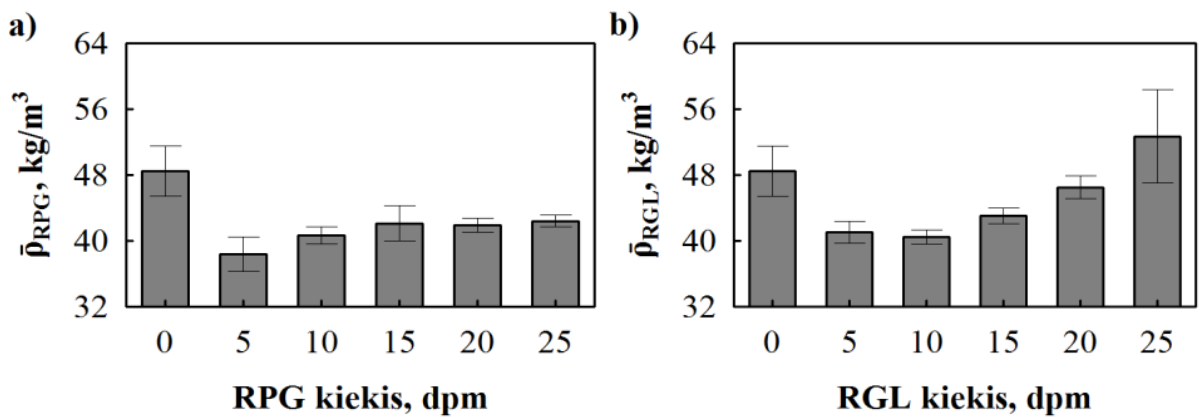

3.7 pav. Standžiujų poliuretano putų tariamojo tankio kitimas priklausomai nuo a) propilenglikolio ir b) glicerino kiekių poliolio mišinyje

Fig. 3.7. The change of apparent density of polyurethane foam depending on a) propylene glycol and b) glycerine amounts in polyol mixture

Galima pastebėti, kad RPG ir RGL modifikuotų poliuretano putų tariamasis tankis, esant 5 dpm kiekiui, vidutiniškai sumažèjo $21 \%$ ir $19 \%$, lyginant su kontrolinemis poliuretano putomis. Galima daryti prielaidą, kad naudojant grandinès 
plètiklius didèja putų išsipūtimo efektyvumas, kurị, mažèjant mišinių molekulinei masei, sukelia sumažèjusi mišinio klampa, lemianti didesnèmis akutėmis pasižyminčią gaminio struktūrą (B priedas, B1 ir B2 lentelès).

Didejant RPG ir RGL kiekiams nuo 5 dpm iki 25 dpm, stebimas tariamojo tankio didējimas. Tokị tankių kitimo skirtumą lemia funkcinių grupių skaičius žaliavinèse PRG ir RGL medžiagose, t. y. 2 ir 3. Tankių didejimo priežastis gali būti didejjantis hidroksilų skaičius ir atitinkamai izocianato kiekis, reikalingas poliuretano putų formavimui, kai naudojamas tas pats $\mathrm{NCO} / \mathrm{OH}$ santykis.

Taip pat galima pastebèti, kad RPG modifikuotos putos pasižymi mažesniu tankiu nei RGL modifikuoti gaminiai, tačiau labai panašia didejimo tendencija. RGL, skirtingai nei RPG, yra trifunkcinis grandinès plètiklis, todèl poliolio-RGL mišiniuose didèja hidroksilų skaičius, o gaminiuose - skersinių grandžių tankis, lemiantis stiprumines poliuretano putų savybes. Šių savybių kitimui didelį poveikị turi taip pat ir kietujjų bei minkštųjų segmentų santykis bei kietujų segmentų stabilumas ir stiprumas (Szycher 2012). 3.8 paveikslas rodo RPG ir RGL modifikuotų poliuretano putų gniuždymo stiprio kitimą, kintant grandinès plètiklių kiekiams poliolio mišinyje.
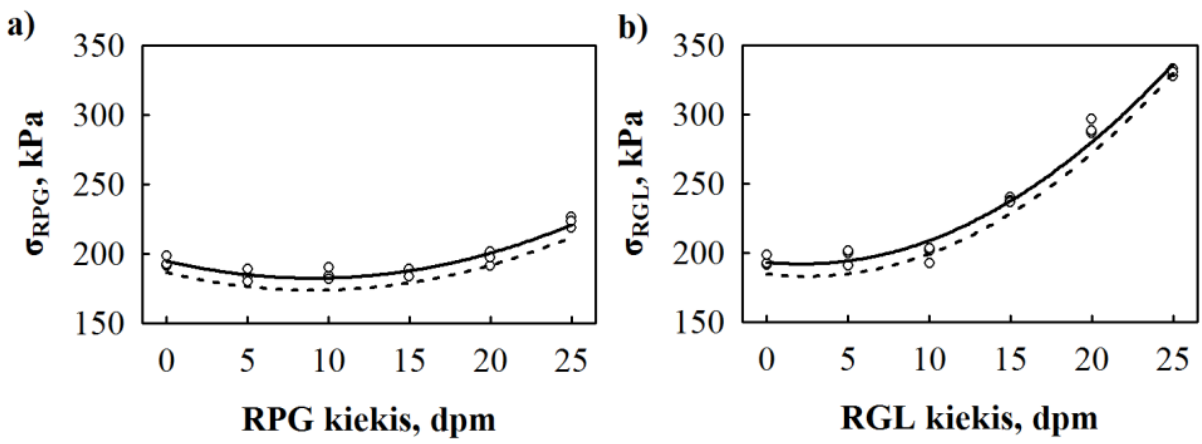

3.8 pav. Standžiụjų poliuretano putu gniuždymo stiprio priklausomybè nuo a) propilenglikolio ir b) glicerino kiekių. $\circ-$ eksperimentiniai duomenys; $(-)$ - regresinè linija; (-----) - prognozuojamoji linija

Fig. 3.8. Dependence of polyurethane foam compressive strength on a) propylene glycol and b) glycerine amounts. $\bigcirc$ - experimental data; $(-)$ - regression line; $(-----)-$ prediction line

Siekiant kiekybiškai ịvertinti šiuos faktorius, buvo atlikta matematinė ir statistinė analizè, kuri rodo, kad vidutinès RPG modifikuotų poliuretano putų gniuždymo stiprio vertès gali būti aprašytos (3.2) regresine lygtimi su vidutiniu kvadratiniu nuokrypiu $S_{\bar{\sigma}_{R P G}}=10,2 \mathrm{kPa}$ ir koreliacijos santykio kvadratu $\eta_{\bar{\sigma}_{R P G}}^{2}=0,916$ : 


$$
\bar{\sigma}_{R P G}=194,8-2,75 \cdot m_{R P G}+0,152 \cdot m_{R P G}^{2},
$$

čia $\bar{\sigma}_{R P G}$-vidutinè RPG modifikuotų poliuretano putų gniuždymo stiprio vertè, $\mathrm{kPa} ; m_{R P G}-\mathrm{RPG}$ kiekis poliolio mišinyje, dpm. Prognozuojamasis vienpusis rezultatų, kurių tikimybè $95 \%$, pasikliautinasis intervalas $\sigma_{R P G, p r o g n}=\bar{\sigma}_{R P G} \pm \delta$, rezultatu skaičius $n=18$ ir Stjudento kriterijus $t_{\alpha}=1,73$, kai $\alpha=0,05$ (3.8 a paveikslas, punktyrinè linija). Vidutinès RGL modifikuotų poliuretano putų gniuždymo stiprio vertès gali būti aprašytos (3.3) regresine lygtimi su vidutiniu kvadratiniu nuokrypiu $S_{\bar{\sigma}_{R G L}}=9,12 \mathrm{kPa}$ ir koreliacijos santykio kvadratu $\eta_{\bar{\sigma}_{R C L}}^{2}=0,979$ :

$$
\bar{\sigma}_{R G L}=193,1-1,18 \cdot m_{R G L}+0,276 \cdot m_{R G L}^{2},
$$

čia $\bar{\sigma}_{R G L}$-vidutinè RGL modifikuotų poliuretano putų gniuždymo stiprio vertè, $\mathrm{kPa} ; m_{R G L}-\mathrm{RGL}$ kiekis poliolio mišinyje, dpm. Prognozuojamasis vienpusis rezultatų, kurių tikimybè $95 \%$, pasikliautinasis intervalas $\sigma_{R G L \text { progn }}=\bar{\sigma}_{R G L} \pm \delta$, rezultatų skaičius $n=18$ ir Stjudento kriterijus $t_{\alpha}=1,73$, kai $\alpha=0,05$ (3.8 b paveikslas, punktyrinè linija).

Pasiūlyti netiesinès regresijos modeliai (3.2) ir (3.3) rodo, kad gniuždymo stoprių pokyčius atitinkamai 91,6\% ir 97,9\% lemia grandinès plètiklių kiekių pokyčiai (RPG ir RGL - nuo $0 \mathrm{dpm}$ iki $25 \mathrm{dpm}$ ), esant 2.2.2 poskyryje paminètiems formavimo suděčiai ir formavimo bei bandymo sąlygoms. Šios lygtys galioja atitinkamai 184-223 kPa (RPG sudètims) ir 194-331 kPa (RGL sudètims) gniuždymo stirpių ribose.

3.8 paveikslas rodo, kad nuo 5 dpm iki 15 dpm RPG ir nuo 5 dpm iki 10 dpm RGL modifikuotų poliuretano putų vidutinès gniuždymo vertès kito labai mažai, atitinkamai vidutiniškai sumažejo nuo 5,10 \% iki 3,50\% ir vidutiniškai padidejjo nuo $1,60 \%$ iki 2,50 \%, lyginant su kontrolinių poliuretano putų vidutine gniuždymo stiprio verte. Tai galima būtų paaiškinti nepakankamu kietụjų segmentų $\left(K S_{\text {Uretano }}+K S_{\text {Ureja }}\right)$ kiekiu galutiniuose gaminiuose (B priedas, B1 ir B2 lentelès). Pasiekus tam tikrą kietujų segmentų kiekio ribą, stebimas intensyvesnis gniuždymo stiprio verčių didèjimas. Galima daryti prielaidą, kad papildomų skersinių grandžių atsiradimas lemia standesnes akučių sieneles ir atitinkamai stipresnę polimerinę matricą.

Pagal gautus reaktyvumo, tariamojo tankio, pradinès susitraukties bei matmenų stabilumo rezultatus, tinkamas grandinès plètiklis standžiųų poliuretano putų gamyboje yra RPG, kuris lemia stabilias matmenų atžvilgiu putas, termoizoliacinėms putoms charakteringą tankị, kintantị nuo $40,7 \mathrm{~kg} / \mathrm{m}^{3} \mathrm{iki} 41,9 \mathrm{~kg} / \mathrm{m}^{3}$, bei 
sumažina laiką, reikalingą gaminių gamybai nuo 215 s iki 133 s, 124 s ir 118 s, atitinkamai naudojant $10 \mathrm{dpm}, 15 \mathrm{dpm}$ ir $20 \mathrm{dpm}$ RPG.

\subsection{Popieriaus gamybos atliekų dumblo daleliụ padengimo titanato jungiamaja medžiaga poveikis mišinių klampai}

Literatūros apžvalga parodè, kad dideliu armuojančių dalelių kiekiu užpildytos polimerinès sistemos pasižymi didele klampa, prastu daleliu pasiskirstymu mišinyje ir nevienodomis savybėmis visame gaminio tūryje, todèl PGAD dalelès buvo dengiamos $1 \%$ titanato jungiamaja medžiaga.

3.4 lentelëje pateikti rezultatai rodo poliolio ir RPG mišinių dinaminès klampos kitimą priklausomai nuo procentinių nedengtų ir dengtų PGAD dalelių kiekių mišiniuose.

Didinant PGAD dalelių kiekị nuo $5 \%$ iki $20 \%$, poliolio ir RPG mišinių dinaminè klampa didèja, tačiau galima pastebèti, kad PGAD dalelių padengimas lemia žymiai mažesnę poliolio ir RPG mišinių, modifikuotų PGAD dalelėmis, dinaminę klampą. $3.9 \mathrm{a}$ ir b paveikslai rodo, kad titanato jungiamoji medžiaga dalelès paviršiuje formuoja sluoksni, kurị ištyrus buvo rastas Ti cheminis elementas (3.9 pav. c ir d). Tai įrodo, jog PGAD dalelių padengimas buvo sèkmingas.

3.4 lentelè. Poliolio ir propilenglikolio mišinių dinaminès klampos rezultatai

Table 3.4. Dynamic viscosity results of polyol and propylene glycol mixtures

\begin{tabular}{|c|c|c|c|c|c|}
\hline \multirow{2}{*}{$\begin{array}{c}\text { RPG } \\
\text { kiekis, } \\
\text { dpm }\end{array}$} & 0 & 5 & 10 & 15 & 20 \\
\cline { 2 - 6 } & \multicolumn{7}{|c|}{ PGAD daleliu kiekis, masės \% } \\
\hline 10 & $324,2 \pm 5,63$ & $514,3 \pm 4,23$ & $722,6 \pm 3,11$ & $1010 \pm 3,22$ & $1400 \pm 5,25$ \\
\hline 15 & $323,9 \pm 5,31$ & $511,4 \pm 5,16$ & $720,4 \pm 4,87$ & $998,2 \pm 3,45$ & $1390 \pm 4,95$ \\
\hline 20 & $322,8 \pm 5,00$ & $508,6 \pm 6,22$ & $717,6 \pm 5,63$ & $981,3 \pm 5,45$ & $1380 \pm 4,66$ \\
\hline \multicolumn{7}{|c|}{ Su dengtomis PGAD dalelèmis, $\mathrm{m} \cdot \mathrm{Pa}$} \\
\hline 10 & $324,2 \pm 5,63$ & $340,5 \pm 4,12$ & $412,3 \pm 6,01$ & $509,3 \pm 5,53$ & $619,3 \pm 4,67$ \\
\hline 15 & $323,9 \pm 5,31$ & $338,6 \pm 4,89$ & $411,4 \pm 5,30$ & $507,4 \pm 3,24$ & $617,2 \pm 5,82$ \\
\hline 20 & $322,8 \pm 5,00$ & $336,2 \pm 4,90$ & $409,7 \pm 5,12$ & $505,9 \pm 3,79$ & $615,7 \pm 5,80$ \\
\hline
\end{tabular}

Didžiausia dinamine klampa pasižymėjo 10 dpm RPG ir $20 \%$ PGAD dalelèmis modifikuoti poliolio mišiniai, kuriuose, padengus PGAD daleles $1 \%$ 
pagal užpildo masę titanato jungiamąja medžiaga, minètasis parametras vidutiniškai sumažèjo $\sim 55,8 \%$.

Lyginant su kontroliniais poliolio ir RPG mišiniais, nuo $5 \%$ iki $20 \%$ nedengtomis PGAD dalelèmis modifikuotų mišinių dinaminè klampa vidutiniškai padidejjo nuo $\sim 58 \%$ iki $\sim 330 \%$, nepriklausomai nuo RPG kiekio poliolio mišinyje. Nuo $5 \%$ iki $20 \%$ dengtomis PGAD dalelėmis modifikuotų mišinių dinaminè klampa vidutiniškai padidejo nuo $\sim 4,5 \%$ iki $~ 91 \%$, nepriklausomai nuo RPG kiekio poliolio mišinyje.
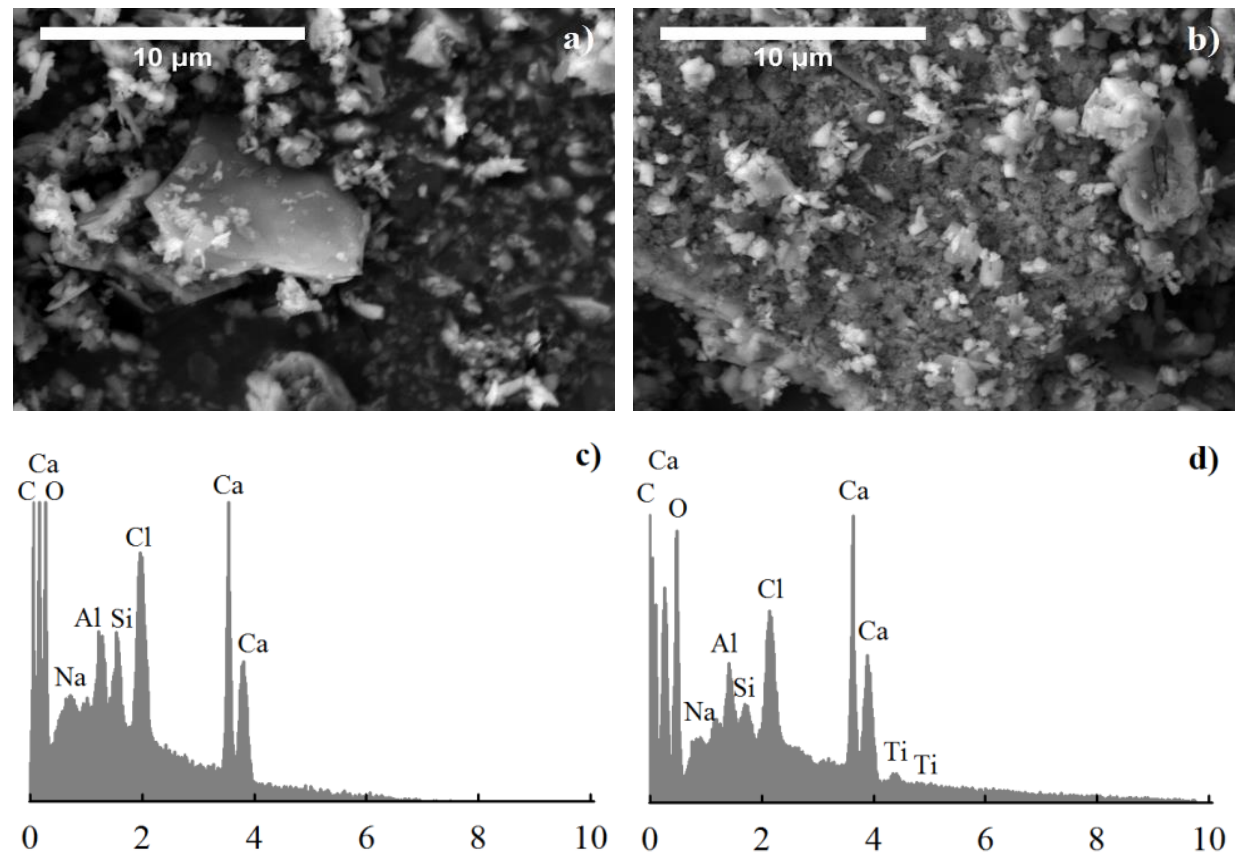

Energija, keV

Energija, keV

3.9 pav. Popieriaus gamybos atliekų dumblo dalelių nuotraukos ir energijos dispersijos spektrogramos prieš padengimą $(\times 5000)$ a) ir c) ir po padengimo $(\times 5000)$ b) ir d) $1 \%$ pagal užpildo masę titanato jungiamaja medžiaga

Fig. 3.9. Images and energy dispersion spectrograms of paper production waste sludge particles before coating $(\times 5000)$ a) and c) and after coating with $1 \mathrm{wt}$. $\%$ titanate coupling agent $(\times 5000) b)$ and $d)$

Lyginant $20 \%$ dengtomis PGAD dalelèmis modifikuotų poliolio mišinių dinaminę klampą su $20 \%$ nedengtomis PGAD dalelėmis modifikuotų mišinių dinamine klampa, galima pastebèti, kad parametras sumažėjo $\sim 2,3$ karto, esant 
bet kokiam RPG kiekiui. Nedengtomis ir dengtomis PGAD dalelèmis modifikuotų poliolio ir RPG mišinių klampos skirtumo priežastis yra titanato jungiamosios medžiagos veikimo principas, kuris yra paremtas besiformuojančių aglomeratų ardymu ir tolygiu dalelių paskirstymu mišiniuose.

\subsection{Mišinių reakcijos kinetikos ir modifikuotų poliuretano putų tariamojo tankio tyrimai}

Dažniausiai termoizoliacinėse medžiagose naudojamų užpildų tankis yra didesnis nei pačios polimerinès matricos, todèl svarbu ịvertinti galutinių poliuretano putų, nuo $5 \%$ iki $20 \%$ modifikuotų PGAD dalelèmis, tariamaji tankị. Jo skaitinių reikšmių bei šių reikšmių kitimo priklausomybe nuo PGAD dalelių kiekio pateikta 3.10 paveiksle.

Gauti rezultatai rodo, kad 10 dpm, 15 dpm ir 20 dpm RPG modifikuotų standžiųjų poliuretano putų tariamasis tankis priklauso nuo PGAD dalelių kiekio. Didèjant šios atliekos kiekiui, bandinių tariamasis tankis taip pat didejja.

Siekiant kiekybiškai ịvertinti šiuos faktorius, buvo atlikta matematinè ir statistiné analizè, kuri rodo, kad vidutinès RPG ir PGAD dalelèmis modifikuotu poliuretano putų tariamojo tankio vertès gali būti aprašytos (3.4) regresine lygtimi.

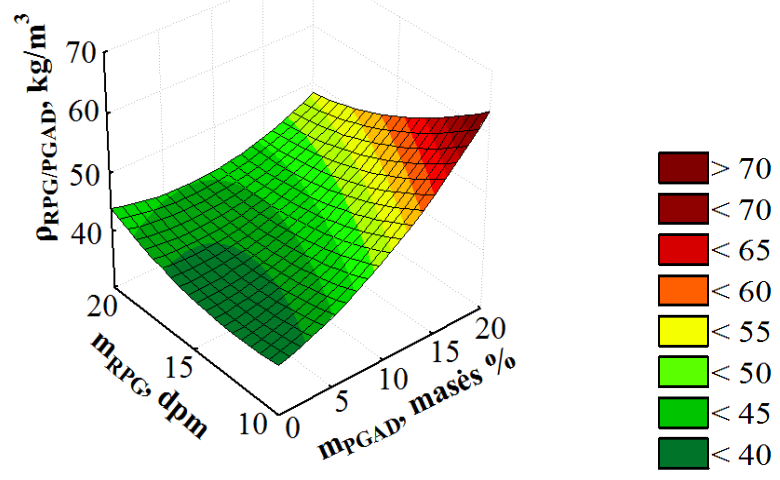

3.10 pav. Poliuretano putu tariamojo tankio priklausomybès nuo propilenglikolio ir popieriaus gamybos atliekų dumblo dalelių kiekių grafinè interpretacija

Fig. 3.10. Graphical interpretation of apparent density dependence of polyurethane foam on the amounts of propylene glycol and paper production waste sludge particles

Šios lygties vidutinis kvadratinis nuokrypis $S_{\bar{\rho}_{R P G / P G A D}}=2,93 \mathrm{~kg} / \mathrm{m}^{3}$ ir koreliacijos santykio kvadratas $\eta_{\bar{\rho}_{R P G / P G A D}}^{2}=0,843$ : 


$$
\begin{gathered}
\bar{\rho}_{R P G / P G A D}=53,0+1,52 \cdot m_{P G A D}-2,44 \cdot m_{R P G}+0,0376 \cdot m_{P G A D}^{2}- \\
0,103 \cdot m_{P G A D} \cdot m_{R P G}+0,0996 \cdot m_{R P G}^{2},
\end{gathered}
$$

čia $\bar{\rho}_{R P G / P G A D}$ - vidutinè RPG ir PGAD dalelèmis modifikuotų poliuretano putų tariamojo tankio verte, $\mathrm{kg} / \mathrm{m}^{3} ; \quad m_{P G A D}-\mathrm{PGAD}$ dalelių kiekis, masès $\%$; $m_{R P G}-$ RPG kiekis, dpm.

Pasiūlytas modelis (3.4) rodo, kad tariamojo tankio pokyčius $84,3 \%$ lemia RPG (nuo $10 \mathrm{dpm}$ iki $20 \mathrm{dpm}$ ) ir PGAD dalelių (nuo $0 \%$ iki $20 \%$ ) kiekių pokyčiai, esant 2.2.3 poskyryje paminètiems formavimo sudèčiai ir formavimo bei bandymo sąlygoms. Gautas modelis galioja $33,9-70,9 \mathrm{~kg} / \mathrm{m}^{3}$ tariamojo tankio ribose.

Galima pastebėti, kad, didinant PGAD dalelių kiekị nuo $5 \%$ iki $20 \%$, poliuretano putų tankis taip pat didejja. Poliuretano putų, modifikuotų $5 \%$ PGAD dalelèmis, tariamasis tankis vidutiniškai padidejo $\sim 11 \%, \sim 0,2 \%$ ir $\sim 2 \%$, modifikuotu $10 \%$ PGAD dalelèmis $-\sim 18 \%, \sim 3 \%$ ir $\sim 4 \%$, modifikuotu $15 \%$ PGAD dalelėmis $-\sim 44 \%, \sim 8 \%$ ir $\sim 9 \%$, modifikuotu $20 \%$ PGAD dalelèmis $-\sim 78 \%, \sim 15 \%$ ir $\sim 21 \%$, atitinkamai esant $10 \mathrm{dpm}, 15 \mathrm{dpm}$ ir $20 \mathrm{dpm}$ RPG kiekiams. Tai galima paaiškinti tipiniu neorganinių dalelių poveikiu. Jos didina žaliavų mišinio klampą, tokiu būdu mažindamos sistemoje esančių komponentų reaktyvumą, kuris, mažindamas išsipūtimo gebą, didina gautų poliuretano putų tankį. Šio teiginio įrodymui atlikti RPG ir PGAD dalelèmis modifikuotų poliuretano putų būdingujų reakcijos laikų, t. y. tirštējimo, standèjimo bei nelipnumo laikų ir galutinio gaminio aukščio tyrimai (3.5 lentelè). Gauti rezultatai rodo, jog galutinis $20 \%$ PGAD dalelèmis modifikuotų poliuretano putų aukštis vidutiniškai sumažejo $\sim 10 \%$, nepriklausomai nuo RPG kiekio poliolio mišinyje.

3.5 lentelè. Būdingieji propilenglikoliu ir popieriaus gamybos atliekų dumblo dalelèmis modifikuotų mišinių reakcijos laikai ir galutinis gaminių aukštis

Table 3.5. Characteristic foaming times of propylene glycol and paper production waste sludge particles modified mixtures and final height of products

\begin{tabular}{|c|c|c|c|c|}
\hline $\begin{array}{c}\text { PGAD dalelių } \\
\text { kiekis, masės \% }\end{array}$ & $\begin{array}{c}\text { Reakcijos } \\
\text { pradžios lai- } \\
\text { kas, s }\end{array}$ & $\begin{array}{c}\text { Standējimo } \\
\text { pradžios lai- } \\
\text { kas, s }\end{array}$ & $\begin{array}{c}\text { Nelipnumo lai- } \\
\text { kas, s }\end{array}$ & $\begin{array}{c}\text { Galutinis ga- } \\
\text { minio aukštis, } \\
\text { mm }\end{array}$ \\
\hline \multicolumn{5}{|c|}{$10 \mathrm{dpm}$ RPG } \\
\hline 0 & $49 \pm 1$ & $107 \pm 3$ & $133 \pm 2$ & $225 \pm 4$ \\
\hline 5 & $55 \pm 2$ & $117 \pm 3$ & $140 \pm 3$ & $219 \pm 2$ \\
\hline 10 & $61 \pm 2$ & $131 \pm 4$ & $154 \pm 2$ & $215 \pm 3$ \\
\hline 15 & $78 \pm 1$ & $149 \pm 5$ & $188 \pm 5$ & $210 \pm 5$ \\
\hline 20 & $92 \pm 3$ & $160 \pm 2$ & $227 \pm 4$ & $201 \pm 5$ \\
\hline
\end{tabular}


3.5 lentelès pabaiga

\begin{tabular}{|c|c|c|c|c|}
\hline $\begin{array}{c}\text { PGAD daleliu } \\
\text { kiekis, masės \% }\end{array}$ & $\begin{array}{c}\text { Reakcijos } \\
\text { pradžios lai- } \\
\text { kas, s }\end{array}$ & $\begin{array}{c}\text { Standèjimo } \\
\text { pradžios lai- } \\
\text { kas, s }\end{array}$ & $\begin{array}{c}\text { Nelipnumo lai- } \\
\text { kas, s }\end{array}$ & $\begin{array}{c}\text { Galutinis ga- } \\
\text { minio aukštis, } \\
\text { mm }\end{array}$ \\
\hline \multicolumn{5}{|c|}{15 dpm RPG } \\
\hline 0 & $54 \pm 2$ & $97 \pm 2$ & $124 \pm 3$ & $228 \pm 4$ \\
\hline 5 & $59 \pm 3$ & $108 \pm 2$ & $135 \pm 2$ & $223 \pm 3$ \\
\hline 10 & $67 \pm 3$ & $124 \pm 1$ & $141 \pm 5$ & $217 \pm 4$ \\
\hline 15 & $87 \pm 3$ & $131 \pm 3$ & $162 \pm 4$ & $212 \pm 4$ \\
\hline 20 & $101 \pm 2$ & $146 \pm 1$ & $180 \pm 3$ & $204 \pm 2$ \\
\hline \multicolumn{5}{|c|}{20 dpm RPG } \\
\hline 0 & $56 \pm 3$ & $96 \pm 3$ & $118 \pm 3$ & $234 \pm 3$ \\
\hline 5 & $62 \pm 2$ & $105 \pm 3$ & $127 \pm 1$ & $229 \pm 2$ \\
\hline 10 & $72 \pm 1$ & $119 \pm 4$ & $134 \pm 2$ & $222 \pm 2$ \\
\hline 15 & $91 \pm 1$ & $128 \pm 1$ & $158 \pm 4$ & $218 \pm 3$ \\
\hline 20 & $105 \pm 4$ & $137 \pm 4$ & $172 \pm 4$ & $211 \pm 5$ \\
\hline
\end{tabular}

Nors didejantis PGAD dalelių kiekis RPG modifikuotų poliuretano putų mišiniuose paveikẻ būdinguosius laikus, tačiau reakcijos kinetikos tendencija išliko tokia pati.

Lyginant su kontrolinėmis poliuretano putomis, nuo $5 \%$ iki $20 \%$ PGAD dalelių ịvedimas į polimerinę sistemą pavèlino $10 \mathrm{dpm}, 15 \mathrm{dpm}$ ir $20 \mathrm{dpm}$ RPG modifikuotų mišinių reakcijos pradžią, atitinkamai nuo $6 \mathrm{~s}$ iki $43 \mathrm{~s}$, nuo $5 \mathrm{~s}$ iki $47 \mathrm{~s}$ ir nuo $6 \mathrm{~s}$ iki $49 \mathrm{~s}$, standejjimo pradžią - nuo $10 \mathrm{~s}$ iki $53 \mathrm{~s}$, nuo $11 \mathrm{~s}$ iki $49 \mathrm{~s}$ ir nuo $9 \mathrm{~s}$ iki $41 \mathrm{~s}$, nelipnumo laiką - nuo $7 \mathrm{~s}$ iki $94 \mathrm{~s}$, nuo $9 \mathrm{~s}$ iki $56 \mathrm{~s}$ ir nuo $11 \mathrm{~s}$ iki $54 \mathrm{~s}$. Gauti rezultatai patvirtina, jog dalelių naudojimas poliuretano putų mišiniuose atideda reakcijos pradžią ir sulètina putų formavimąsi.

\subsection{Modifikuotų poliuretano putų stipruminių savybių tyrimai}

Dauguma tradicinių poliuretano putu pasižymi tokiomis mechaninèmis savybèmis, kurių skaitinès vertès tiesiogiai priklauso nuo tariamojo tankio. Kaip parodè literatūros apžvalga, kompozitinèse sistemose dideli poveikị turi užpildo tipas, jo modifikavimas, užpildo dalelių dydis, forma bei užpildo ir matricos sąveika, todèl labai svarbu įvertinti šių faktorių poveikị pagrindinèms RPG ir PGAD dalelèmis modifikuotų poliuretano putų mechaninèms savybèms - gniuždymo ir tempimo stipriams.

3.11 paveikslas rodo, kad, didinant PGAD dalelių kiekị nuo $5 \%$ iki $20 \%$ visose RPG modifikuotose sistemose, poliuretano putų gniuždymo stipris didèja. 
Tai reiškia, kad PGAD dalelès ne tik padidina medžiagos tariamajị tankị, bet ir standumą. Galima daryti prielaidą, kad gniuždymo stiprio didejjimą lemia tvirtesnè jungtis tarp PGAD dalelių ir polimerinès matricos, dèl to atsiranda efektyvesnis įtempimų perdavimas iš matricos užpildui medžiagos apkrovimo metu.

Lyginant su kontrolinėmis poliuretano putomis, PGAD dalelèmis modifikuotų poliuretano putų gniuždymo stipris, esant maksimaliam PGAD dalelių kiekiui, vidutiniškai padidejo $\sim 52,7 \%, \sim 31,3 \%$ ir 22,7 \%, atitinkamai, kai poliolio mišiniuose naudoti $10 \mathrm{dpm}, 15 \mathrm{dpm}$ ir $20 \mathrm{dpm}$ RPG kiekiai. Taip pat galima pastebèti, kad, didinat RPG kiekị nuo 10 dpm iki 20 dpm, gniuždymo stiprio didejjimo tendencija mažèja. Tai gali būti paaiškinama tuo, kad didèjantis RPG kiekis poliolio mišinyje lemia trapesne, tačiau stipresne struktūra pasižyminčias putas, tai sumažina tarpfazinị sukibimą tarp PGAD dalelès ir polimerinès matricos.

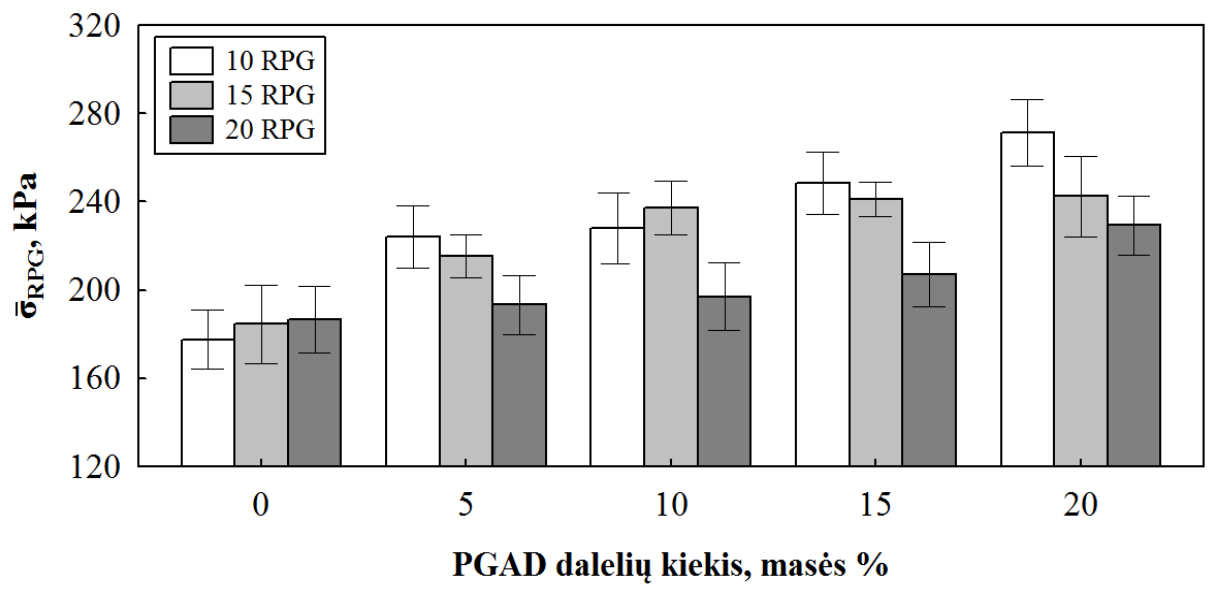

3.11 pav. Propilenglikolio ir popieriaus gamybos atliekų dumblo dalelių poveikis poliuretano putų gniuždymo stipriui

Fig. 3.11. The impact of propylene glycol and paper production waste sludge particles on compressive strength of polyurethane foam

Tuo pačiu gali būti paaiškinamas ir tempimo stiprio mažèjimas PGAD dalelèmis modifikuotose putose, kuriose naudotas RPG kiekis kito nuo $15 \mathrm{dpm}$ iki 20 dpm (3.12 pav.). Kintant PGAD dalelių kiekiui nuo $5 \%$ iki $20 \%$, 15 dpm ir 20 dpm RPG modifikuotų putų tempimo stipris vidutiniškai sumažèjo, atitinkamai, nuo $\sim 9,64 \%$ iki $\sim 24,2 \%$ ir nuo $\sim 3,32 \%$ iki $\sim 19,7 \%$, tačiau, kaip galima pastebetti iš 3.12 paveikslo, $10 \mathrm{dpm}$ RPG kiekis neturi minètojo poveikio poliuretano putoms. Galima daryti prielaidą, kad, kintant PGAD dalelių kiekiui nuo $5 \%$ iki $15 \%$, tempimo stiprio vertès didèja dèl tolygaus dalelių pasiskirstymo $10 \mathrm{dpm}$ RPG ir poliolio mišinyje bei pakankamo tarpfazinio sukibimo, atsirandančio 
PGAD daleles padengus titanato jungiamaja medžiaga, kurios veikimo principas pateiktas 3.13 paveiksle.

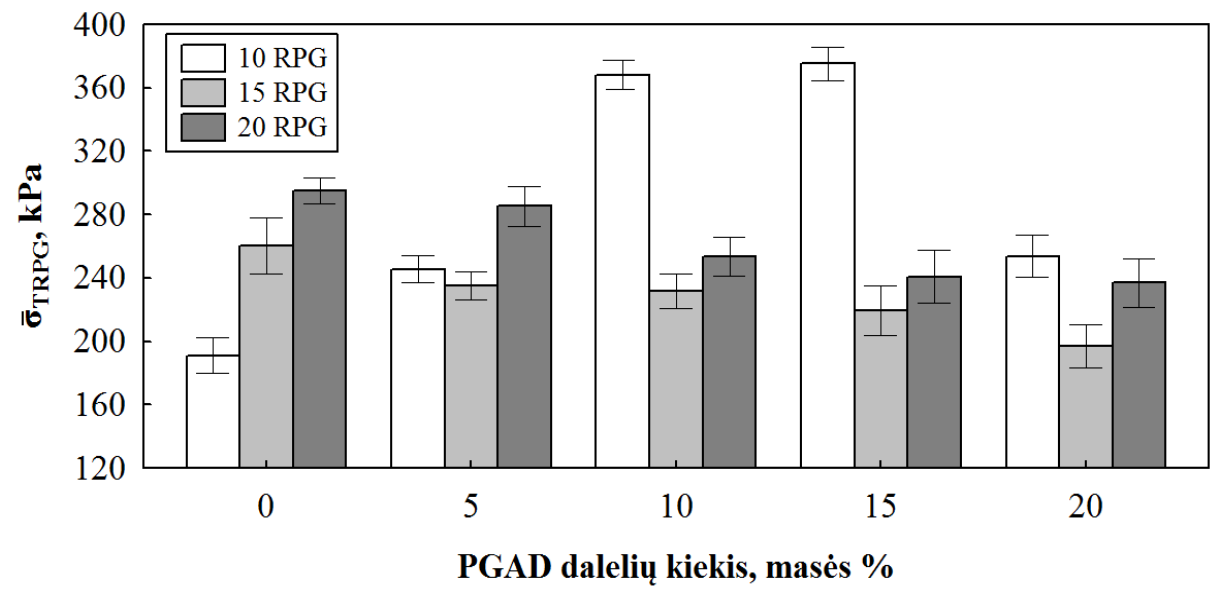

3.12 pav. Propilenglikolio ir popieriaus gamybos atliekų dumblo dalelių poveikis poliuretano putų tempimo stipriui

Fig. 3.12. The impact of propylene glycol and paper production waste sludge particles on tensile strength of polyurethane foam

Titanato jungiamoji medžiaga reaguoja su PGAD dalelès paviršiuje esančiomis hidroksilų grupèmis (dalelių drègnis 1,5\% (2.4 lentelè), tokiu būdu formuodama sluoksnị, kuris padidina neorganinio užpildo ir polimerinès matricos suderinamumą ir to pasèkoje - sukibimą.

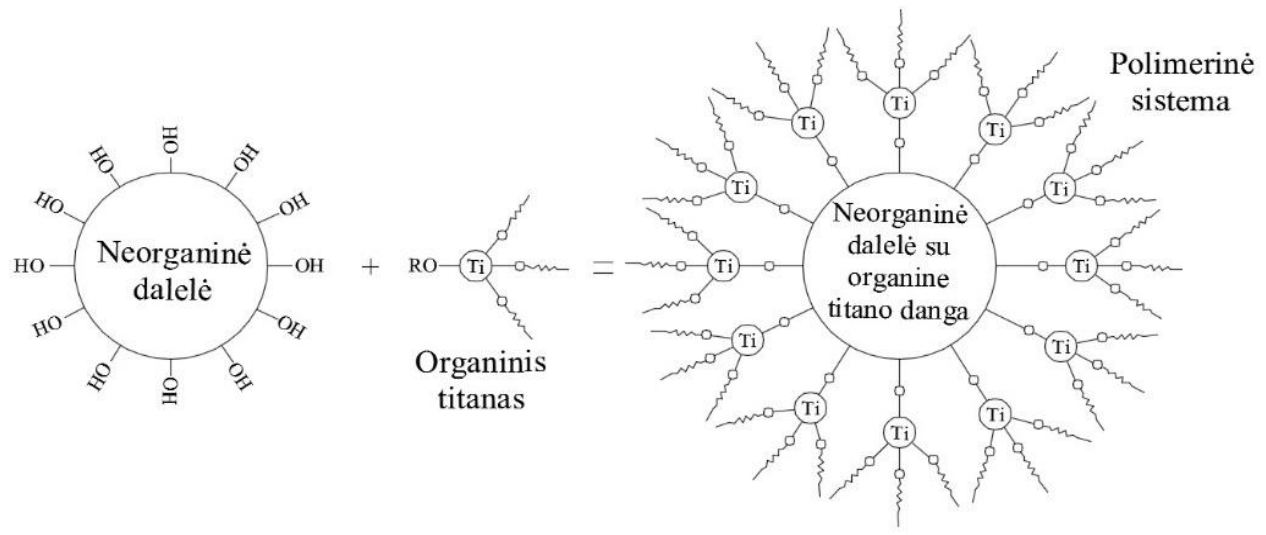

3.13 pav. Titanato jungiamosios medžiagos veikimo principas (Badhe et al. 2015)

Fig. 3.13. Operating principle of titanate coupling agent (Badhe et al. 2015) 

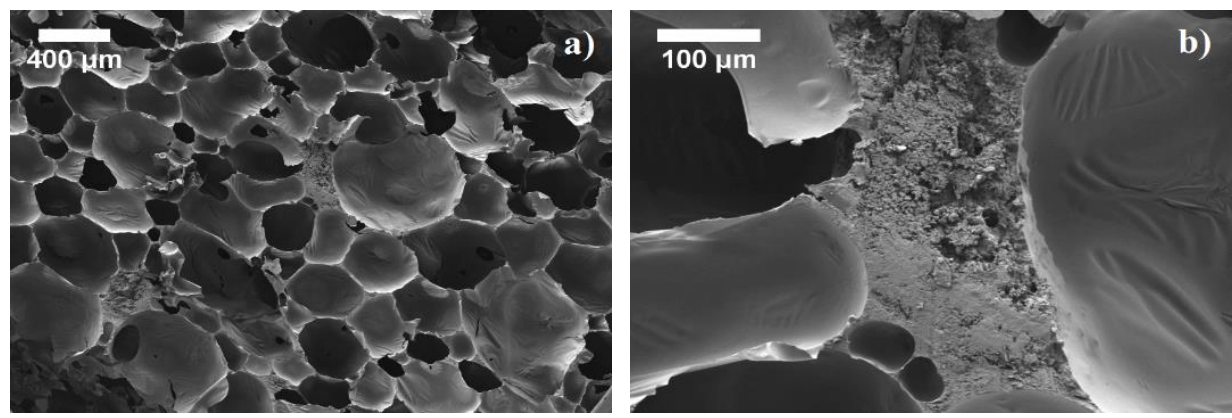

3.14 pav. 10 dalių pagal masę propilenglikoliu ir $20 \%$ popieriaus gamybos atliekų dumblo dalelèmis modifikuotos poliuretano putos: a) mikrostruktūra (didinimas $\times 35$ );

b) popieriaus gamybos atliekų dumblo daleliu aglomeratas tarpuporyje (didinimas $\times 200$ )

Fig. 3.14. 10 parts by weight of propylene glycol and 20 wt. $\%$ of paper production waste sludge particles modified polyurethane foam: a) microstructure

$($ magnification $\times 35)$; b) agglomerate in the strut of paper production waste sludge particles (magnification $\times 200$ )

Todèl 10 dpm RPG ir nuo $5 \%$ iki $15 \%$ PGAD dalelèmis modifikuotos poliuretano putos atitinkamai pasižymi vidutiniškai nuo $\sim 28,5 \%$ iki $\sim 96,3 \%$ didèjančiu tempimo stipriu.

Lyginant vidutines tempimo stiprių vertes, esant $15 \%$ ir $20 \%$ PGAD dalelių kiekiui, minètasis parametras vidutiniškai sumažejo $\sim 32,4 \%$. Tai gali būti paaiškinama tuo, kad, esant $20 \%$ ir didesniam PGAD kiekiui, sistema yra perpildoma, tam tikrose jos vietose pradeda formuotis aglomeratai, kurių rezultatas - oro tuštumų polimerinės matricos ir dalelès sąlyčio vietoje formavimasis, dẻl nehomogeniškos aglomeracijos kanalų susidarymas (3.14 pav. a) ir daliné struktūroje esančių akučių destrukcija (3.14 pav. b). Taip pat galima pastebėti, kad aglomeratai formuojasi struktūroje esančių akučių tarpuporiuose.

\subsection{Modifikuotų poliuretano putų struktūros ir šilumos laidumo tyrimai}

Kaip 3.5 poskyryje pateikti rezultatai rodo, RPG ir PGAD dalelėmis modifikuotų poliuretano putų stipruminès savybès priklauso nuo dalelès ir polimerinès matricos sąveikos intensyvumo, tačiau pagrindinė termoizoliacinių medžiagų savybe் - šilumos laidumo koeficientas - priklauso nuo laidumo akutèse esančiomis dujomis ir polimeru bei spinduliavimo tarp akučių arba, kitaip tariant - nuo struktūros. 3.15 paveiksle pateikiamos $10 \mathrm{dpm}$ (3.15 pav. a ir b), $15 \mathrm{dpm}$ (3.15 pav. c ir d) ir $20 \mathrm{dpm}$ (3.15 pav. e ir f) RPG modifikuotų poliuretano putų be PGAD dalelių ir su $20 \%$ PGAD dalelèmis nuotraukos. 

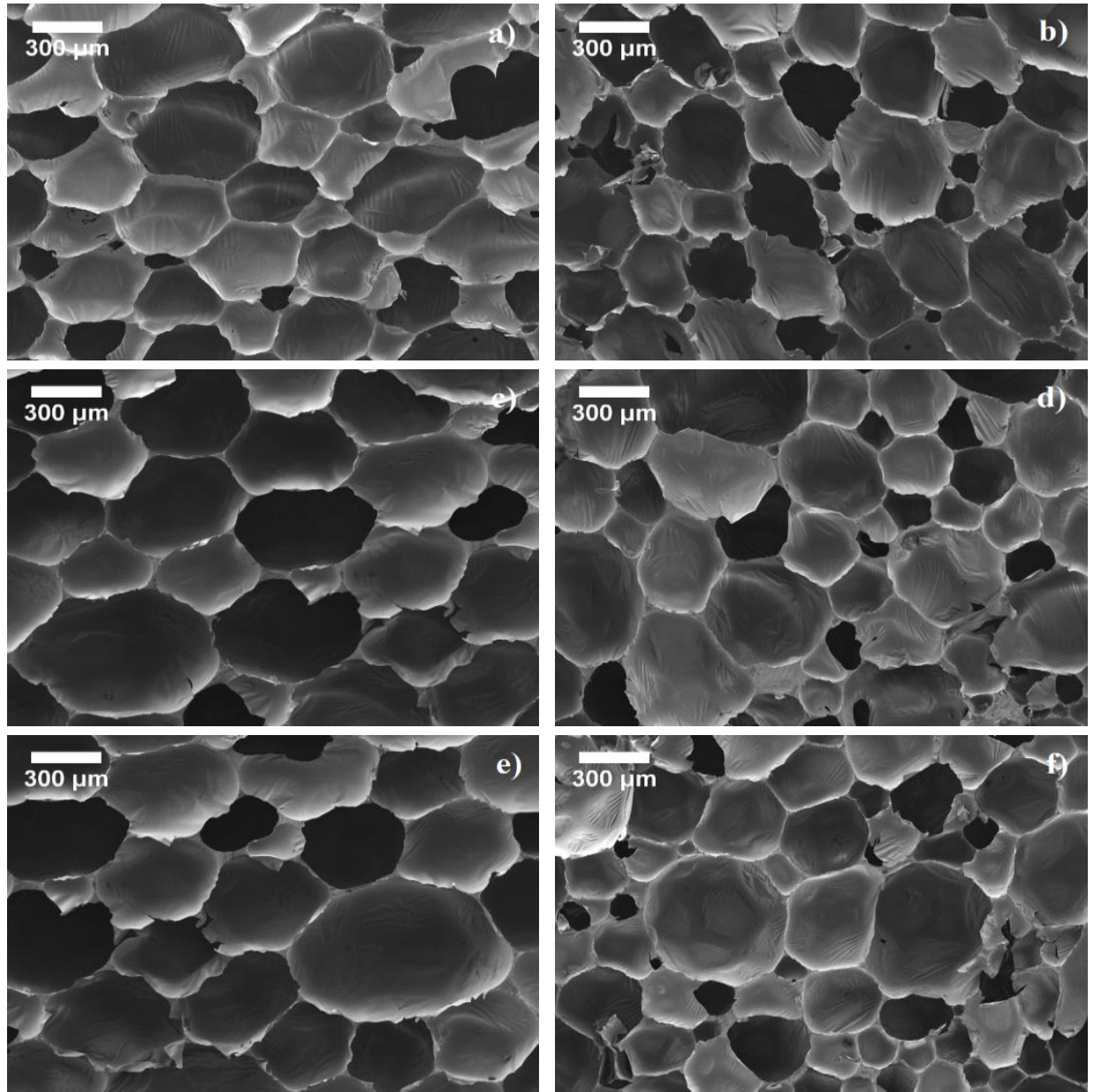

3.15 pav. Poliuretano putu, modifikuotų: a) 10 dalių pagal masę propilenglikoliu; b) 10 dalių pagal masę propilenglikoliu ir $20 \%$ pagal masę popieriaus gamybos atliekų dumblo dalelėmis; c) 15 dalių pagal masę propilenglikoliu; d) 15 dalių pagal masę propilenglikoliu ir $20 \%$ pagal masę popieriaus gamybos atliekų dumblo dalelėmis; e) 20 dalių pagal masę propilenglikoliu; f) 20 dalių pagal masę propilenglikoliu ir $20 \%$ pagal masę popieriaus gamybos atliekų dumblo dalelèmis mikrostruktūra

$($ didinimas $\times 50)$

Fig. 3.15. Microstructure of polyurethane foam modified with: a) 10 parts by weight of propylene glycol; b) 10 parts by weight of propylene glycol and $20 \mathrm{wt}$. \% of paper production waste sludge; c) 15 parts by weight of propylene glycol; d) 15 parts by weight of propylene glycol and 20 wt. \% of paper production waste sludge; e) 20 parts by weight of propylene glycol; f) 20 parts by weight of propylene glycol and 20 wt. \% of paper production waste sludge (magnification $\times 50$ ) 
Mikrostruktūros nuotraukos ir 3.6 lentelè rodo, kad, lyginant su kontrolinèmis putomis, PGAD dalelèmis modifikuotos poliuretano putos pasižymi daline arba visiška uždarų akučių sistema bei mažèjančiu akučių dydžiu. 10 dpm RPG modifikuotų poliuretano putų vidutiniai procentiniai uždarų akučių kiekiai, lyginant su kontrolinėmis poliuretano putomis, yra vidutiniškai $14,7 \%, 16,5 \%$, $19,9 \%$ ir $27,9 \%, 15 \mathrm{dpm}$ RPG modifikuotų putu $-45,7 \%, 47,6 \%, 49,1 \%$ ir $51,3 \%, 20$ dpm RPG modifikuotu putu $-58,7 \%, 60,0 \%, 60,6 \%$ ir 62,0\% didesni, atitinkamai, kai naudojama $5 \%, 10 \%, 15 \%$ ir $20 \%$ PGAD dalelių.

Didejant uždarų akučių kiekiui, akučių dydis mažèja. Tai reiškia, kad tame pačiame tūryje susidaro daugiau mažesnių akučių. Patys aktyviausi užuomazgas sudarantys centrai yra 0,1-1 $\mu \mathrm{m}$ ribose (Mullin 2001), o PGAD dalelių dydis $>0,04 \mu \mathrm{m}$, todèl atitinkama dalis PGAD dalelių veikia kaip užuomazgas sudarantys centrai, mažindami struktūroje esančių akučių dydị. Net ir 5 \% PGAD dalelių, akučių dydị vidutiniškai sumažina 10,9 \%, 34,9 \% ir 30,9 \%, atitinkamai 10 dpm, $15 \mathrm{dpm}$ ir $20 \mathrm{dpm}$ RPG modifikuotose poliuretano putose.

3.6 lentelė. Propilenglikoliu ir popieriaus gamybos atliekų dumblo dalelèmis modifikuotų poliuretano putų struktūriniai parametrai

Table 3.6. Structural parameters of propylene glycol and paper production waste sludge particles modified polyurethane foam

\begin{tabular}{|c|c|c|c|c|c|c|}
\hline \multirow{2}{*}{ Parametras } & \multirow{2}{*}{$\begin{array}{l}\text { RPG kie- } \\
\text { kis, dpm }\end{array}$} & \multicolumn{5}{|c|}{ PGAD dalelių kiekis, masės \% } \\
\hline & & 0 & 5 & 10 & 15 & 20 \\
\hline \multirow{3}{*}{$\begin{array}{l}\text { Uždarų } \\
\text { akučių kie- } \\
\text { kis, \% }\end{array}$} & 10 & $64,4 \pm 4,7$ & $79,1 \pm 3,6$ & $80,9 \pm 1,2$ & $84,3 \pm 2,2$ & $92,3 \pm 4,8$ \\
\hline & 15 & $31,3 \pm 2,4$ & $77,0 \pm 4,2$ & $78,9 \pm 3,7$ & $80,4 \pm 2,4$ & $82,6 \pm 4,0$ \\
\hline & 20 & $18,5 \pm 2,4$ & $77,2 \pm 2,8$ & $78,5 \pm 2,3$ & $79,1 \pm 4,2$ & $80,5 \pm 3,8$ \\
\hline \multirow{3}{*}{$\begin{array}{l}\text { Akučių dy- } \\
\text { dis, mm }\end{array}$} & 10 & $\begin{array}{c}0,338 \\
\pm 0,052 \\
\end{array}$ & $\begin{array}{c}0,301 \\
\pm 0,024\end{array}$ & $\begin{array}{c}0,298 \\
\pm 0,052 \\
\end{array}$ & $\begin{array}{c}0,284 \\
\pm 0,069 \\
\end{array}$ & $\begin{array}{c}0,275 \\
\pm 0,037 \\
\end{array}$ \\
\hline & 15 & $\begin{array}{c}0,458 \\
\pm 0,034\end{array}$ & $\begin{array}{c}0,298 \\
\pm 0,033\end{array}$ & $\begin{array}{c}0,166 \\
\pm 0,055\end{array}$ & $\begin{array}{c}0,291 \\
\pm 0,048\end{array}$ & $\begin{array}{c}0,284 \\
\pm 0,034 \\
\end{array}$ \\
\hline & 20 & $\begin{array}{r}0,469 \\
\pm 0,067 \\
\end{array}$ & $\begin{array}{c}0,324 \\
\pm 0,047\end{array}$ & $\begin{array}{c}0,312 \\
\pm 0,063 \\
\end{array}$ & $\begin{array}{c}0,295 \\
\pm 0,047 \\
\end{array}$ & $\begin{array}{c}0,285 \\
\pm 0,026 \\
\end{array}$ \\
\hline
\end{tabular}

Žinoma, kad nemodifikuotose poliuretano putose dominuojantis užuomazgų susidarymo procesas ir mechanizmas yra homogeninis ir, lyginant su heterogeniniu, jo metu aktyvacijos energija yra didesnè. Tai reiškia, kad akutès susidarymas yra lètas, o visiškai susidariusios akutès yra didesnès (Mullin 2001). Priešingai, PGAD dalelių panaudojimas igalina dujų ,uždarymą“ dalelès ir polimerinès matricos sąlyčio vietoje. Tokiu būdu susidaro mažos tuštumos, dèl kurių akučių formavimui reikalinga mažesnè aktyvacijos energija, tai lemia mažesnių akučių susidarymą. 
Tolesnis PGAD dalelių kiekio didinimas turi tik labai nežymų poveikį akučių mažèjimui (3.6 lentelè). 15 dpm RPG ir $10 \%$ PGAD dalelėmis modifikuotų putų vidutinis akučių dydis siekia tik $0,166 \mathrm{~mm}$. Tokị poveiki galëjo turèti atsitiktinis didesnis mažesnių nei $1 \mu \mathrm{m}$ dydžio dalelių kiekis PGAD dalelių ịkrovoje bandinių formavimo metu.

Taip pat galima pastebėti, kad kontrolinėse poliuretano putose, didinant RPG kieki nuo $10 \mathrm{dpm}$ iki $20 \mathrm{dpm}$, vidutinis akučių dydis didèja nuo $0,338 \mathrm{~mm}$ iki 0,469 . Tai aiškinama didèjančiu izocianato kiekiu dèl didèjančio poliolio ir RPG mišinio hidroksilų skaičiaus. Didesnis šios medžiagos kiekis lemia efektyvesni poliuretano putų išsipūtimą ir didesnèmis akutèmis pasižyminčią struktūrą.

Didžiają šilumos laidumo koeficiento vertès dali, t. y. 65-80\%, apima šilumos laidumas dujomis ar dujų mišiniu (Jarfelt, Ramnäs 2006). Ši pagrindinè termoizoliacinių poliuretano putų savybè taip pat priklauso ir nuo dujų, naudotų gamyboje, tipo bei jų difuzijos iš gaminio greičio. Šios akutėse esančios dujos per trumpą laiką yra pakeičiamos oru, todèl labai svarbu ịvertinti šio parametro kitimą laike.

Tyrimų rezultatai (C priedas) rodo, kad net $5 \%$ PGAD dalelèmis modifikuotų poliuretano putų šilumos laidumo koeficientas yra vidutiniškai $\sim 19,3 \%$ (10 dpm RPG), 24,8 \% (15 dpm RPG) ir 24,6 \% (20 dpm RPG) mažesnis nei kontrolinių poliuretano putu po 1 dienos po gamybos. Tai galima būtų paaiškinti padidejjusiu procentiniu uždarų akučių kiekiu, nuo kurio priklauso dujų šalinimosi iš medžiagos struktūros greitis, bei sumažèjusiu vidutiniu akučių dydžiu (3.6 lentelè), nuo kurio priklauso viena iš šilumos laidumo komponenčiu - spinduliavimas. Uždarų akučių kiekis yra žymiai mažesnis visose RPG modifikuotose kontrolinèse poliuretano putose, todèl $\mathrm{CO}_{2}$ dujų šalinimasis vyksta greičiau, tai lemia didesnes nei RPG ir PGAD dalelëmis modifikuotų poliuretano putų vidutines šilumos laidumo koeficiento vertes po 1 dienos po gamybos.

PGAD dalelių kiekio didinimas neturi jokio poveikio vidutinèms šilumos laidumo koeficiento vertèms, tačiau galima pastebèti, kad, didinant RPG kiekị nuo $10 \mathrm{dpm}$ iki $20 \mathrm{dpm}$, vidutinès šio parametro vertès po 1 dienos po gamybos padidejja, tačiau labai nežymiai, t. y. iki $2 \%$, nuo $5 \%$ iki $20 \%$ PGAD dalelèmis modifikuotose poliuretano putose.

Nors poliuretano putų modifikavimas PGAD dalelèmis lemia mažesnị šilumos laidumo koeficientą po 1 dienos po gamybos, tačiau po 14 ir 28 dienų po gamybos visų RPG ir PGAD dalelèmis modifikuotų poliuretano putų vidutinès šilumos laidumo koeficiento vertès kinta labai mažose ribose, t. y. tampa panašios.

Siekiant įvertinti PGAD dalelių ir RPG kiekių bei laiko poveikị poliuretano putų šilumos laidumo koeficientams, tyrimų rezultatų pagrindu nustatytas sąryšis, išreiškiamas netiesine regresine lygtimi (3.5): 


$$
\begin{gathered}
\bar{\lambda}_{R P G / P G A D / t}=0,029-0,00052 \cdot m_{P G A D}+0,00080 \cdot t+0,000016 \cdot m_{P G A D}^{2}- \\
0,00020 \cdot t^{2}+0,0000010 \cdot m_{P G A D} \cdot m_{R P G} \cdot t,
\end{gathered}
$$

čia $\bar{\lambda}_{R P G / P G A D / t}$ - vidutinès RPG ir PGAD dalelèmis modifikuotų poliuretano putų šilumos laidumo koeficientų vertès po $t$ dienų išlaikymo po gamybos, $\mathrm{W} /(\mathrm{m} \cdot \mathrm{K})$; $m_{P G A D}-$ PGAD dalelių kiekis, masės $\% ; t-$ RPG ir PGAD dalelėmis modifikuotų poliuretano putų išlaikymo laikas; $m_{R P G}-$ RPG kiekis, dpm. RPG ir PGAD dalelèmis modifikuotų poliuretano putų šilumos laidumo koeficiento nustatymo rezultatų (3.5 lygtis) vidutinis kvadratinis nuokrypis $S_{\bar{\lambda}_{R P G / P G A D / t}}=0,00142 \mathrm{~W} /(\mathrm{m} \cdot \mathrm{K})$, o koreliacijos santykio kvadratas $\eta_{\bar{\lambda}_{R P G / P G A / t}}^{2}=0,886$.

Pasiūlytas modelis (3.5) rodo, kad šilumos laidumo koeficiento pokyčius 88,6 \% lemia RPG (nuo 10 dpm iki 20 dpm), PGAD daleliu (nuo $0 \%$ iki $20 \%$ ) kiekių ir išlaikymo po gamybos laiko (nuo 1 dienos iki 28 dienų) pokyčiai, esant 2.2.3 poskyryje paminètiems formavimo sudèčiai ir formavimo bei bandymo sąlygoms. Ši lygtis galioja $0,0253-0,0359 \mathrm{~W} /(\mathrm{m} \cdot \mathrm{K})$ šilumos laidumo koeficiento ribose.

\subsection{Modifikuotų poliuretano putų tiesinių matmenų pokyčių tyrimai}

Literatūroje pateikiamos informacijos apie poliuretano putų matmenų pokyčius nèra daug, tačiau daugelis mokslininkų (Kurańska et al. 2016, Hejna et al. 2017), siekdami išvengti dèl mažo funkcinių grupių skaičiaus polioliuose iš atsinaujinančių išteklių atsirandančių perteklinių susitraukimų ir neigiamų tiesinių matmenų pokyčių padidintos temperatūros ir drègmès sąlygomis, esamus poliolius modifikuoja didesnị funkcinių grupių skaičių turinčiais polioliais, kurie, savo sudètyje turėdami naftos produktų, sumažina bendrą atsinaujinančių išteklių kiekị gaminyje. PGAD dalelėmis ir RPG modifikuotų poliuretano putu gamyboje naudotas propilenglikolis iš rapsų glicerino, kurio poveikis galutinio gaminio matmenų pokyčiams (pradinei susitraukčiai po 1 dienos po gamybos ir matmenų stabilumui $70{ }^{\circ} \mathrm{C}$ temperatūros ir $90 \%$ santykinès drègmès aplinkoje) pavaizduotas 3.16 paveiksle. Galima pastebeti skirtumą tarp $10 \mathrm{dpm}$ RPG ir nuo $15 \mathrm{dpm}$ iki $20 \mathrm{dpm}$ RPG bei PGAD dalelèmis modifikuotų poliuretano putų matmenų pokyčių rezultatų.

10 dpm RPG modifikuotų poliuretano putų procentinè pradiné susitrauktis vidutiniškai padidèjo nuo MS(0/0/0) iki MS(1,5/2,6/3,4), atitinkamai ilgio, pločio ir storio kryptimis, kai sistemoje naudotas maksimalus PGAD dalelių kiekis. 

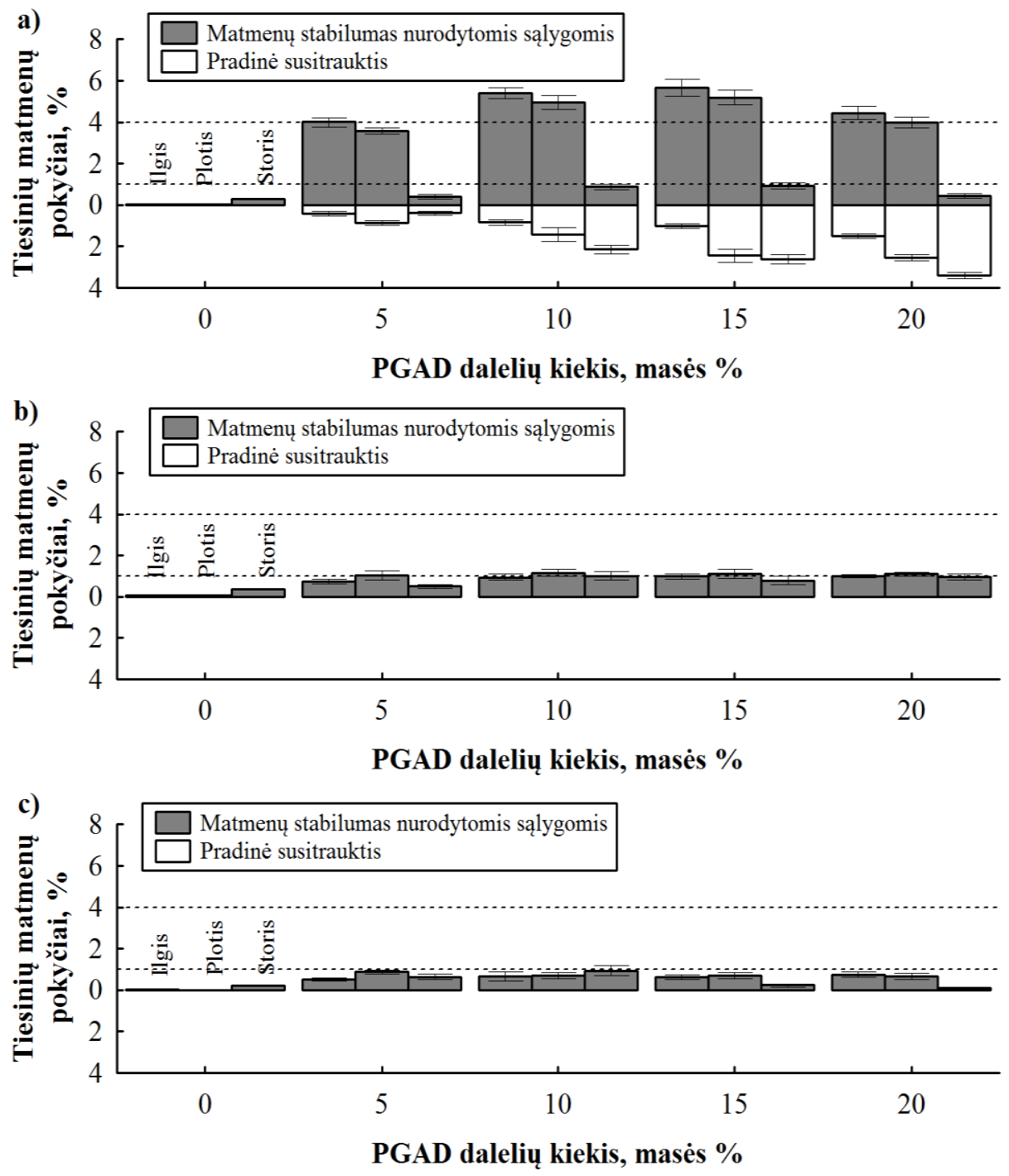

3.16 pav. Popieriaus gamybos atliekų dumblo dalelėmis modifikuotų poliuretano putų pradinè susitrauktis ir matmenų stabilumas, kai propilenglikolio kiekis dalimis pagal masę: a) 10; b) 15 ir c) 20. (------) - griežčiausi reikalavimai matmenų pokyčiams ilgio, pločio ir storio kryptimis pagal LST EN 13165 reikalavimus

Fig. 3.16. Initial shrinkage and dimensional stability of paper production waste sludge particles modified polyurethane foam when propylene glycol amount in parts by weight is: a) 10; b) 15 and c) 20 . (------) - the strictest requirements for dimensional changes in the directions of length, width and thickness according to LST EN 13165 requirements 
To priežastis yra PGAD dalelių geba skatinti užuomazgų susidarymo procesą, kurio metu susidaro daugiau ir mažesnių uždarų akučių. Uždarų akučių kiekio ir jų dydžio poveikis aptartas 3.5 skyriuje. Taip pat galima pastebèti panašią i pradinès susitraukties matmenų stabilumo padidintos temperatūros ir drègmès aplinkoje rezultatų tendenciją. Gamybos metu PGAD dalelëmis ir 10 dpm RPG modifikuotos poliuretano putos pasižymi uždarapore struktūra, todèl $\mathrm{CO}_{2}$ dujų liekamasis kiekis, ịvykus pradinei susitraukčiai, dalyvauja tolesniame šalinimosi procese matmenų stabilumo padidintoje temperatūroje ir drègmèje nustatymo metu.

Gerai žinoma, jog temperatūra ir difuzijos greitis yra tiesiogiai proporcingi dydžiai, todèl galima pabrèžti, jog, didèjant temperatūrai, didèja $\mathrm{CO}_{2}$ dujų greitis per akučių sieneles dẻl padidejjusios energijos, reikalingos dujų dalelių skverbimuisi iš struktūros i gamini supančią aplinką. Priešingai 3.16 a paveiksle pateiktiems rezultatams, $3.16 \mathrm{~b}$ ir $3.16 \mathrm{c}$ paveikslai rodo, kad, didejant mažos molekulinès masès RPG kiekiui nuo $15 \mathrm{dpm}$ iki $20 \mathrm{dpm}$ didelès molekulinès masès poliolyje, net ir esant maksimaliam $20 \%$ pagal masę PGAD dalelių kiekiui, galima gauti struktūriškai ir matmenų atžvilgiu stabilias putas, kurių pradinè susitrauktis po 1 dienos po gamybos yra lygi $0 \% .15 \mathrm{dpm}$ ir $20 \mathrm{dpm}$ RPG ir nuo $5 \%$ iki $20 \%$ PGAD dalelèmis modifikuotų poliuretano putų struktūra yra dalinai uždaraporè, todèl egzistuoja mažas liekamasis $\mathrm{CO}_{2}$ dujų kiekis, kuris, šalindamasis matmenų stabilumo bandymo metu, sukelia matmenų pokyčius. Šie pokyčiai atitinka maksimalius standarto LST EN 13165 reikalavimus, keliamus gamykliniams standiesiems poliuretano putu gaminiams, t. y. $\leq 1 \%$ ilgio ir pločio bei $\leq 4 \%$ storio kryptimis. Taip pat galima pastebèti, kad, lyginant su kontrolinėmis $15 \mathrm{dpm}$ ir $20 \mathrm{dpm}$ RPG modifikuotomis poliuretano putomis, procentinis matmenu pokytis, esant 5\% PGAD daleliu kiekiui, pakito, atitinkamai nuo $\operatorname{MS}(0,06 / 0,06 / 0,35)$ iki $\mathrm{MS}(0,75 / 1,0 / 0,51)$ ir nuo $\mathrm{MS}(0,03 / 0,01 / 0,23)$ iki MS(0,51/0,88/0,64). Toliau didinant PGAD dalelių kiekị nuo $5 \%$ iki $20 \%$, matmenų pokytis ilgio, pločio ir storio kryptimis matmenų stabilumo bandymo metu yra nežymus, didžiausią poveiki šio parametro kitimui turi RPG kiekis poliolio mišinyje.

\subsection{Modifikuotų poliuretano putų drègminių savybių tyrimai}

Naudojant termoizoliacines medžiagas atitvarinèse konstrukcijose, gali pasireikšti vandens poveikis (tiesioginis arba garų pavidalo), nuo kurio intensyvumo priklauso termoizoliacinio sluoksnio fizikinès ir mechaninès savybės. Nuo šių savybių pokyčio priklauso termoizoliacinio sluoksnio panaudojimo sritis, todèl labai svarbu žinoti naudojamos medžiagos drègmines savybes. 3.7 lentelëje pateiktos 
RPG ir PGAD dalelėmis modifikuotų poliuretano putų vandens garų varžos faktoriaus ir ilgalaikès vandens sugerties matavimo rezultatų vidutinès vertès, kurios rodo, kad minètieji parametrai mažèja, didejjant PGAD dalelių kiekiui poliuretano putų sistemose ir RPG kiekiui poliolio mišinyje. Poliolio mišinio modifikavimas RPG lemia kontrolinius poliuretano putu gaminius, pasižyminčius dalinai atvirapore struktūra (3.6 lentelè), todèl vandens garai bandymo metu yra lengviau absorbuojami ir praleidžiami, dèl to stebimas vandens garų varžos faktoriaus mažèjimas bei ilgalaikès vandens sugerties didèjimas, RPG kiekiui didèjant nuo $10 \mathrm{dpm}$ iki $20 \mathrm{dpm}$.

Taip pat iš 3.7 lenteleje pateiktų rezultatų galima pastebėti, jog $10 \mathrm{dpm}$ RPG ir nuo $5 \%$ iki $20 \%$ PGAD dalelèmis modifikuotų poliuretano putu pralaidumo vandens garui dydị lemiančio parametro ir vidutinès ilgalaikès vandens sugerties vertės yra panašios su kontrolinių $10 \mathrm{dpm}$ RPG modifikuotų poliuretano putų vidutinèmis vertèmis.

3.7 lentelè. Propilenglikoliu ir popieriaus gamybos atliekų dumblo dalelèmis modifikuotų poliuretano putų pralaidumo vandens garui ir ilgalaikės vandens sugerties tyrimo rezultatai

Table 3.7. Results of water vapour transmission and long - term water absorption of propylene glycol and paper production waste sludge particles modified polyurethane foam

\begin{tabular}{|c|c|c|c|c|c|c|}
\hline \multirow{2}{*}{ Parametras } & \multirow{2}{*}{$\begin{array}{c}\text { RPG } \\
\text { kiekis, } \\
\text { dpm }\end{array}$} & \multicolumn{5}{|c|}{ PGAD dalelių kiekis, masès \% } \\
\hline & & 0 & 5 & 10 & 15 & 20 \\
\hline \multirow{3}{*}{$\begin{array}{l}\text { Vandens garų } \\
\text { varžos faktorius } \\
\mu, \text { b. d. }\end{array}$} & 10 & $\begin{array}{l}42,9 \\
\pm 3,6\end{array}$ & $\begin{array}{l}43,7 \\
\pm 2,3\end{array}$ & $\begin{array}{l}44,5 \\
\pm 2,2\end{array}$ & $\begin{array}{l}41,3 \\
\pm 2,0\end{array}$ & $\begin{array}{l}44,9 \\
\pm 3,5\end{array}$ \\
\hline & 15 & $\begin{array}{l}40,9 \\
\pm 3,7\end{array}$ & $\begin{array}{l}34,4 \\
\pm 3,8\end{array}$ & $\begin{array}{l}33,5 \\
\pm 1,4\end{array}$ & $\begin{array}{l}32,5 \\
\pm 2,8\end{array}$ & $\begin{array}{l}26,2 \\
\pm 1,2\end{array}$ \\
\hline & 20 & $\begin{array}{l}39,7 \\
\pm 4,3\end{array}$ & $\begin{array}{l}33,1 \\
\pm 4,6\end{array}$ & $\begin{array}{l}28,8 \\
\pm 3,0\end{array}$ & $\begin{array}{l}25,9 \\
\pm 3,4\end{array}$ & $\begin{array}{l}27,4 \\
\pm 3,8\end{array}$ \\
\hline \multirow{3}{*}{$\begin{array}{l}\text { Ilgalaikè van- } \\
\text { dens sugertis vi- } \\
\text { siškai jame pa- } \\
\text { nardinus, tūrio } \\
\%\end{array}$} & 10 & $\begin{array}{c}5,69 \\
\pm 0,25 \\
\end{array}$ & $\begin{array}{c}5,63 \\
\pm 0,37 \\
\end{array}$ & $\begin{array}{c}5,52 \\
\pm 0,37 \\
\end{array}$ & $\begin{array}{c}5,27 \\
\pm 0,051\end{array}$ & $\begin{array}{c}5,35 \\
\pm 0,39 \\
\end{array}$ \\
\hline & 15 & $\begin{array}{c}6,06 \\
\pm 0,90\end{array}$ & $\begin{array}{c}7,98 \\
\pm 0,61\end{array}$ & $\begin{array}{c}8,40 \\
\pm 0,65 \\
\end{array}$ & $\begin{array}{c}8,57 \\
\pm 0,66\end{array}$ & $\begin{array}{c}10,7 \\
\pm 0,41\end{array}$ \\
\hline & 20 & $\begin{array}{c}6,03 \\
\pm 0,096\end{array}$ & $\begin{array}{c}8,57 \\
\pm 0,34\end{array}$ & $\begin{array}{c}9,86 \\
\pm 0,39\end{array}$ & $\begin{array}{c}9,67 \\
\pm 0,43\end{array}$ & $\begin{array}{c}9,79 \\
\pm 0,41\end{array}$ \\
\hline
\end{tabular}

Galima daryti prielaida, kad tokias vandens garų varžos faktoriaus ir vandens sugerties vertes lemia efektyvus PGAD dalelių padengimas titanato jungiamaja medžiaga, dalelès paviršiuje formuojančia vienos molekulès dydžio sluoksni, lemiantị dalelès ir polimerinès matricos sąveikos intensyvumą. Šiuo atveju dalelè ir 
matrica pasižymi geru tarpfaziniu sukibimu, kuris neleidžia dalelès ir polimerinės matricos sąveikos vietoje formuotis plyšiams ir kanalams, pro kuriuos galètu patekti vandens garai pralaidumo vandens garui bandymo metu ir skverbtis vandens molekulèms ilgalaikès vandens sugerties visiškai jame panardinus bandymo metu.

Kaip stiprumo tyrimų rezultatai parodè, $15 \mathrm{dpm}$ ir $20 \mathrm{dpm}$ RPG ir nuo $5 \%$ iki $20 \%$ modifikuotų poliuretano putų tempimo stipris, didejjant PGAD dalelių kiekiui, mažèja dèl to, jog mažos molekulinès masès difunkcinis RPG lemia trapesne struktūra pasižyminčias putas, kurių adhezija kitų paviršių atžvilgiu yra mažesnè.

Pagal 3.7 lentelèje pateiktus rezultatus galima daryti prielaidą, kad PGAD dalelès ir polimerinès matricos sąlyčio vietoje formuojasi ertmès, pro kurias praeina vandens garai, todèl vandens garų varžos faktorius, didejjant PGAD dalelių kiekiui, mažèja. Vandens garų varžos faktorius, lyginant su kontrolinių 15 dpm RPG modifikuotu poliuretano putu, vidutiniškai sumažejo $15,9 \%, 18,1 \%, 20,5 \%$ ir $35,9 \%, 20$ dpm RPG modifikuotu putu - 16,6\%, 27,4\%, 34,8 \% ir 31,0\%, atitinkamai, esant $5 \%, 10 \%, 15 \%$ ir $20 \%$ PGAD dalelių kiekiams.

Ilgalaikè vandens sugertis visiškai jame panardinus 28 paras, lyginant su kontrolinèmis $15 \mathrm{dpm}$ RPG modifikuotomis poliuretano putomis, vidutiniškai padidèjo $31,7 \%, 38,6 \%, 41,4 \%$ ir $76,6 \%$ ir $20 \mathrm{dpm}$ RPG modifikuotuc putu $-42,1 \%, 63,5 \%, 60,4 \%$ ir 62,4 \%, atitinkamai, kintant PGAD dalelių kiekiams nuo $5 \%$ iki $20 \%$, žingsniu $5 \%$.

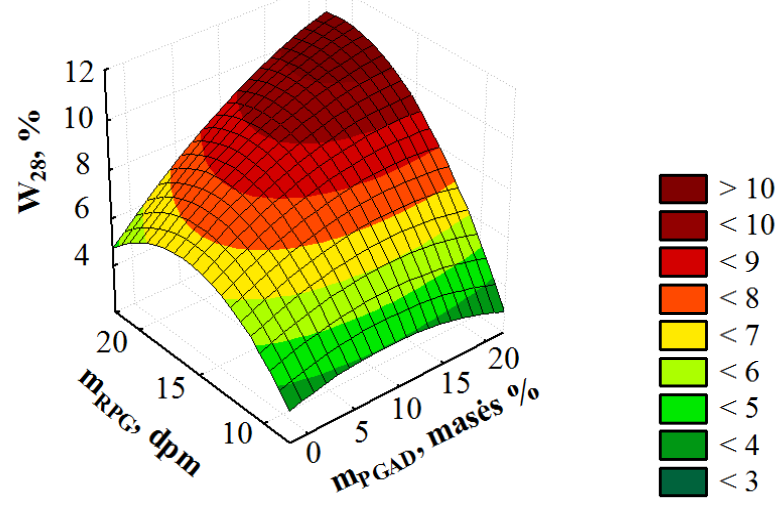

3.17 pav. Poliuretano putų ilgalaikès vandens sugerties panardinus jame priklausomybės nuo propilenglikolio ir popieriaus gamybos atliekų dumblo dalelių kiekių grafinè interpretacija

Fig. 3.17. Graphical interpretation of long - term water absorption by total immersion dependence of polyurethane foam on the amounts of propylene glycol and paper production waste sludge particles 
Siekiant ịvertinti RPG ir PGAD dalelių poveikį ilgalaikei poliuretano putų vandens sugerčiai, atlikta matematinè ir statistinė analizé, kurios metu gauti rezultatai aprašyti regresine lygtimi (3.6), o grafinè šių rezultatų interpretacija pateikta 3.17 paveiksle.

$$
\begin{gathered}
\bar{W}_{28}=-6,02-0,579 \cdot m_{P G A D}+1,59 \cdot m_{R P G}-0,00573 \cdot m_{P G A D}^{2}+ \\
0,0193 \cdot m_{P G A D} \cdot m_{R P G}-0,0483 \cdot m_{R P G}^{2},
\end{gathered}
$$

čia $\bar{W}_{28}$ - vidutinè ilgalaikès vandens sugerties visiškai jame panardinus po 28 parų vertè, $\%$; $m_{P G A D}-$ PGAD dalelių kiekis, masės $\% ; m_{R P G}-$ RPG kiekis, dpm. Šios lygties kvadratinis nuokrypis $S_{\bar{W}_{28}}=0,705 \%$, o koreliacijos santykio kvadratas $\eta_{\bar{W}_{28}}^{2}=0,855$.

Pasiūlytas modelis (3.6) rodo, kad ilgalaikès vandens sugerties visiškai jame panardinus pokyčius 85,5\% lemia RPG (nuo 10 dpm iki $20 \mathrm{dpm}$ ) ir PGAD dalelių (nuo $0 \%$ iki $20 \%$ ) kiekių pokyčiai, esant 2.2.3 poskyryje paminètiems formavimo sudèčiai ir formavimo bei bandymo sąlygu pokyčiams. Pateikta lygtis galioja $4,95-10,3 \%$ ilgalaikès vandens sugerties ribose.

\subsection{Modifikuotų poliuretano putų degumo, užsidegamumo ir terminio stabilumo tyrimai}

Poliuretano putų terminis irimas yra svarbus reiškinys tiek fundamentinès, tiek technologinès perspektyvos atžvilgiu. Irimo procesų tyrimai leidžia nustatyti optimalias sąlygas projektavimo ir gamybos stadijose bei gauti racionaliomis eksploatacinėmis savybėmis pasižyminčius gaminius. Siekiant ịvertinti gautų RPG ir PGAD dalelèmis modifikuotų poliuretano putų elgseną eksploatacinėmis sąlygomis, atlikti degumo ir užsidegamumo tyrimai.

Pagrindinis ir pats svarbiausias parametras, tiesiogiai lemiantis ugnies dydị bei jos plitimo greiț, medžiagos masès nuostolius, toksinių medžiagų išsiskyrimą, yra šilumos išsiskyrimo greitis (HRR). Rezultatų interpretavimui pasirinkti RPG ir PGAD dalelių kiekiai, kurie turejo didžiausią poveikị poliuretano putoms. Kontrolinių poliuretano putu ir $20 \mathrm{dpm}$ RPG bei $10 \%$ ir $20 \%$ PGAD dalelèmis modifikuotų poliuretano putų HRR priklausomybès nuo laiko kreivès pateiktos 3.18 paveiksle.

Galima pastebėti, kad nagrinejjamos poliuretano putos priklauso storus anglinguosius sluoksnius formuojančių medžiagų grupei. Tai reiškia, kad pradinis šilumos išsiskyrimo greičio (HRR) padidejimas stebimas tol, kol susiformuoja anglingasis sluoksnis, žymiai suvaržantis gaisro plitimą. 


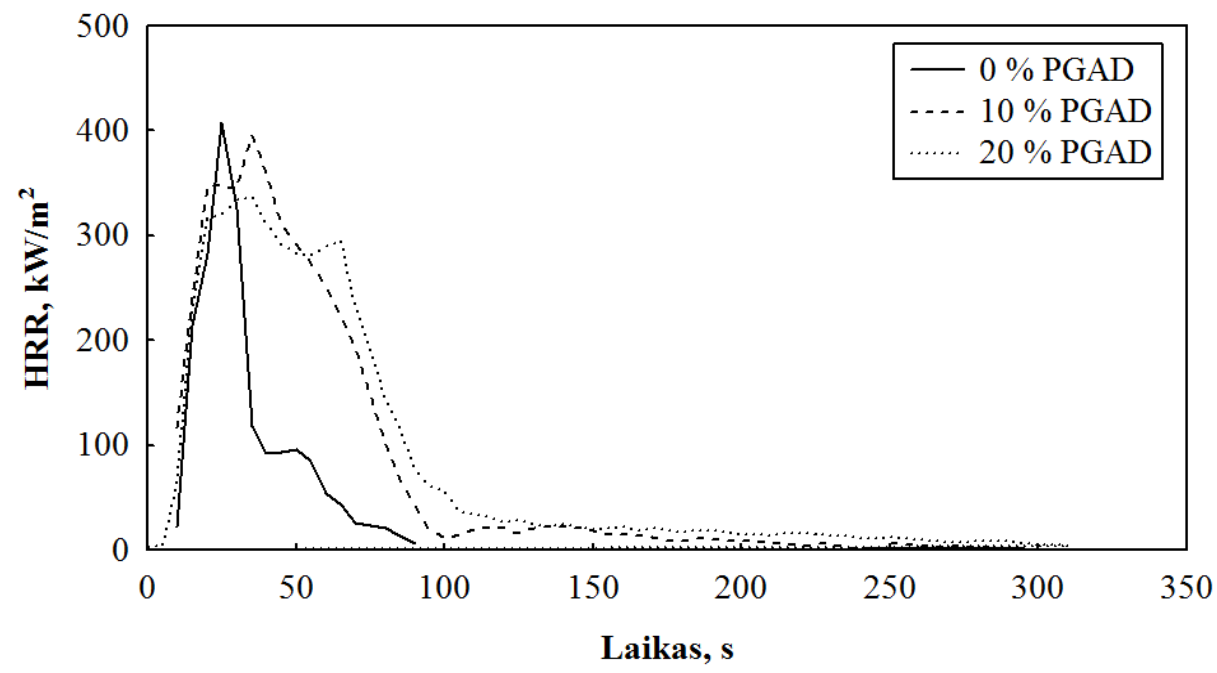

3.18 pav. Kontroliniu poliuretano putų ir $10 \%$ bei $20 \%$ pagal masę popieriaus gamybos atliekų dumblo dalelèmis modifikuotų poliuretano putų šilumos išsiskyrimo greičiu kreivès

Fig. 3.18. Curves of heat release rate of control polyurethane foam and by $10 \mathrm{wt} . \%$ and 20 wt. \% of paper production waste sludge particles modified polyurethane foam

Kontrolinėms poliuretano putoms būdingas staigus anglingojo sluoksnio formavimasis, sumažinantis pHRR (būtent 3.18 paveiksle pateiktiems rezultatams) nuo $408 \mathrm{~kW} / \mathrm{m}^{2}$ iki $118 \mathrm{~kW} / \mathrm{m}^{2}$ po $25 \mathrm{~s}$, tačiau $20 \mathrm{dpm}$ RPG bei $10 \%$ ir $20 \%$ PGAD dalelèmis modifikuotose poliuretano putose pastebimas lètas šio sluoksnio formavimasis ir medžiagos degimas, kuriuos lydi papildomos nežymios smailès, atsirandančios dèl anglingajame sluoksnyje susidarančių mikroplyšių, pro kuriuos patenka deguonis. Lètą anglingojo sluoksnio formavimąsi ir degimą lemia PGAD dalelèse esančio $\mathrm{CaCO}_{3}$ skilimas ir $\mathrm{CO}_{2}$ dujų išsiskyrimas. Šios dujos slopina liepsnos plitimą medžiagoje, sulètindamos anglingojo sluoksnio formavimąsi nuo $25 \mathrm{~s}$ iki $35 \mathrm{~s}$ visoms RPG ir PGAD dalelemis modifikuotoms poliuretano putoms (3.18 paveikslas - laikas, kuomet pasiekiamas pHRR). Ši teigini patvirtina 3.19 paveiksle pateiktos nuotraukos bandinių, kurie buvo veikiami atvira liepsna.

3.8 lentelèje pateiktos vidutinès užsidegamumo, veikiant bandinius atvira liepsna, bandymų rezultatų vertès. Galima pastebėti, kad kuo daugiau PGAD dalelių poliuretano putose, tuo užsidegamumas lètesnis. Lyginant su kontrolinèmis poliuretano putomis, laikas, reikalingas liepsnai pasiekti $150 \mathrm{~mm}$ aukštį, padidèja $2 \mathrm{~s} 10 \%$ PGAD dalelëmis ir $4 \mathrm{~s} 20 \%$ PAGD dalelèmis modifikuotose poliuretano putose. Viso to rezultatas - sumažejęs apanglejusios dalies aukštis. 

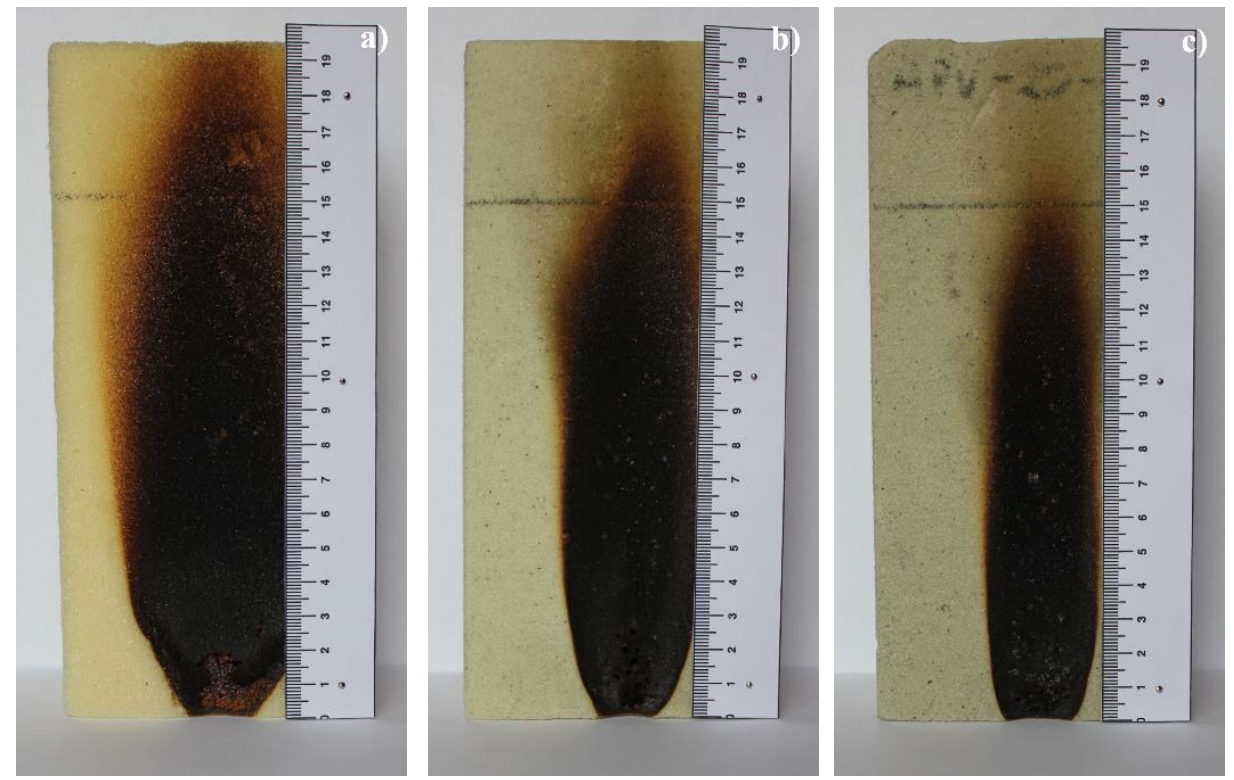

3.19 pav. Liepsnos aukštis po užsidegamumo bandymų a) kontrolinėse poliuretano putose; b) $10 \%$ pagal masę popieriaus gamybos atliekų dumblo dalelemis ir c) $20 \%$ pagal masę popieriaus gamybos atliekų dumblo dalelëmis modifikuotose poliuretano putose

Fig. 3.19. The height of flame after ignitability tests in a) control polyurethane foam; b) by $10 \mathrm{wt}$ \% of paper production waste sludge particles modified and c) by $20 \mathrm{wt} . \%$ of paper production waste sludge particles modified polyurethane foam

3.8 lentelè. Propilenglikoliu ir popieriaus gamybos atliekų dumblo dalelèmis modifikuotụ poliuretano putų užsidegamumo, veikiant atvira liepsna, bandymo rezultatų vidutinès vertès

Table 3.8. Average values of ignitability tests results of propylene glycol and paper production waste sludge particles modified polyurethane foam under open flame

\begin{tabular}{|l|c|c|c|}
\hline \multirow{2}{*}{ Parametras } & \multicolumn{3}{|c|}{ PGAD dalelių kiekis, masės \% } \\
\cline { 2 - 4 } & 0 & 10 & 20 \\
\hline $\begin{array}{l}\text { Laikas, kuomet } \\
\text { liepsna pasiekia } 150 \\
\text { mm aukští, s }\end{array}$ & $6 \pm 1$ & $8 \pm 1$ & $10 \pm 1$ \\
\hline $\begin{array}{l}\text { Apangléjusios dalies } \\
\text { aukštis, mm }\end{array}$ & $187 \pm 4$ & $168 \pm 4$ & $146 \pm 2$ \\
\hline $\begin{array}{l}\text { Savaiminis užgesi- } \\
\text { mas, pašalinus lieps- } \\
\text { nos šaltinị, s }\end{array}$ & - & - & $17 \pm 1$ \\
\hline
\end{tabular}


Taip pat galima pastebèti, kad, esant $20 \%$ PGAD dalelių, poliuretano putos pasižymi savaiminiu užgesimu po $17 \mathrm{~s}$, kuomet pašalinamas liepsnos šaltinis. Tai reiškia, jog didesniu kiekiu PGAD dalelèmis modifikuoti gaminiai nepalaiko degimo ir gali būti laikomi savaime užgęstančiais.

$10 \%$ ir $20 \%$ PGAD dalelių padidina poliuretano putu visuminị šilumos iš-

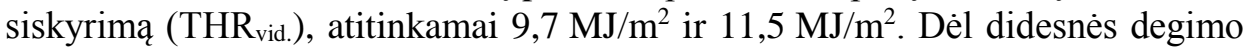
trukmès padidèja ir vidutinis visuminis dūmų išsiskyrimas (TSR vid.) (3.9 lentelè).

Kontrolinių poliuretano putų ir $10 \%$ PGAD dalelėmis modifikuotų poliuretano putų vidutinis maksimalus šilumos išsiskyrimo greitis $\left(\mathrm{pHRR}_{\text {vid. }}\right)$ nepasikeitè, tačiau, padidinus PGAD dalelių kiekị iki $20 \%$, stebimas $19 \mathrm{~kW} / \mathrm{m}^{2}$ mažesnis $\mathrm{pHRR}_{\text {vid. }}$ Tai reiškia, kad didesnis PGAD dalelių kiekis sumažina liepsnos plitimo greiti gaisro metu.

3.9 lentelė. Propilenglikoliu bei popieriaus gamybos atliekų dumblo dalelėmis modifikuotų poliuretano putų vidutinès degumo charakteristikų vertès

Table 3.9. Average values of fire resistance tests of propylene glycol and paper production waste sludge particles modified polyurethane foam

\begin{tabular}{|l|c|c|c|}
\hline \multirow{2}{*}{ Parametras } & \multicolumn{3}{|c|}{ PGAD daleliu kiekis, masės \% } \\
\cline { 2 - 4 } & 0 & 10 & 20 \\
\hline $\mathrm{pHRR}_{\text {vid. }}, \mathrm{kW} / \mathrm{m}^{2}$ & $372 \pm 42$ & $373 \pm 49$ & $353 \pm 47$ \\
\hline $\mathrm{THR}_{\text {vid. }}, \mathrm{MJ} / \mathrm{m}^{2}$ & $12,7 \pm 3,4$ & $22,4 \pm 0,7$ & $24,2 \pm 1,7$ \\
\hline $\mathrm{TSR}_{\text {vid. }}, \mathrm{m}^{2} / \mathrm{m}^{2}$ & $398 \pm 65$ & $801 \pm 62$ & $951 \pm 69$ \\
\hline $\mathrm{COY}_{\text {vid., }} \mathrm{kg} / \mathrm{kg}$ & $0,15 \pm 0,03$ & $0,14 \pm 0,01$ & $0,13 \pm 0,01$ \\
\hline $\mathrm{CO}_{2} \mathrm{Y}_{\text {vid. }}, \mathrm{kg} / \mathrm{kg}$ & $4,4 \pm 0,5$ & $3,4 \pm 0,1$ & $3,1 \pm 0,2$ \\
\hline
\end{tabular}

Naudojant gaminius tose vietose, kur juos gali pasiekti ugnis, būtina ịvertinti degimo produktuose esančių medžiagu - anglies monoksido (CO) ir anglies dioksido $\left(\mathrm{CO}_{2}\right)$ kiekius degimo metu. Galima pastebèti, kad šių medžiagų kiekiai mažèja, didèjant PGAD dalelių kiekiui. Tai reiškia, kad PGAD dalelès išsiskiriančių dūmų ir dujų mišiniuose degimo metu $\mathrm{CO}$ ir $\mathrm{CO}_{2}$ kiekių nedidina.

Gauti $\mathrm{pHRR}_{\text {vid. }}$ ir užsidegamumo bandymų rezultatai rodo, kad PGAD dalelès polimerinejje matricoje ne tik slopina liepsną, bet veikia kaip barjeras liepsnos plitimui ir staigiam šilumos išsiskyrimui dẻl užpildo dalelių dehidratacijos reakcijos ir karboksilo grupių, esančių celiuliozejje, irimo, kurių metu išsiskiria nedegios medžiagos, t. y. $\mathrm{H}_{2} \mathrm{O}$ ir $\mathrm{CO}_{2}$.

Siekiant išnagrinèti, kokie procesai vyksta medžiagos degimo metu, atlikti terminio stabilumo tyrimai - termogravimetrinè (TGA) ir diferencinè terminè (DTA) analizės normaliomis sąlygomis. PGAD dalelių TGA ir DTA kreivès pateiktos 3.20 paveiksle. 


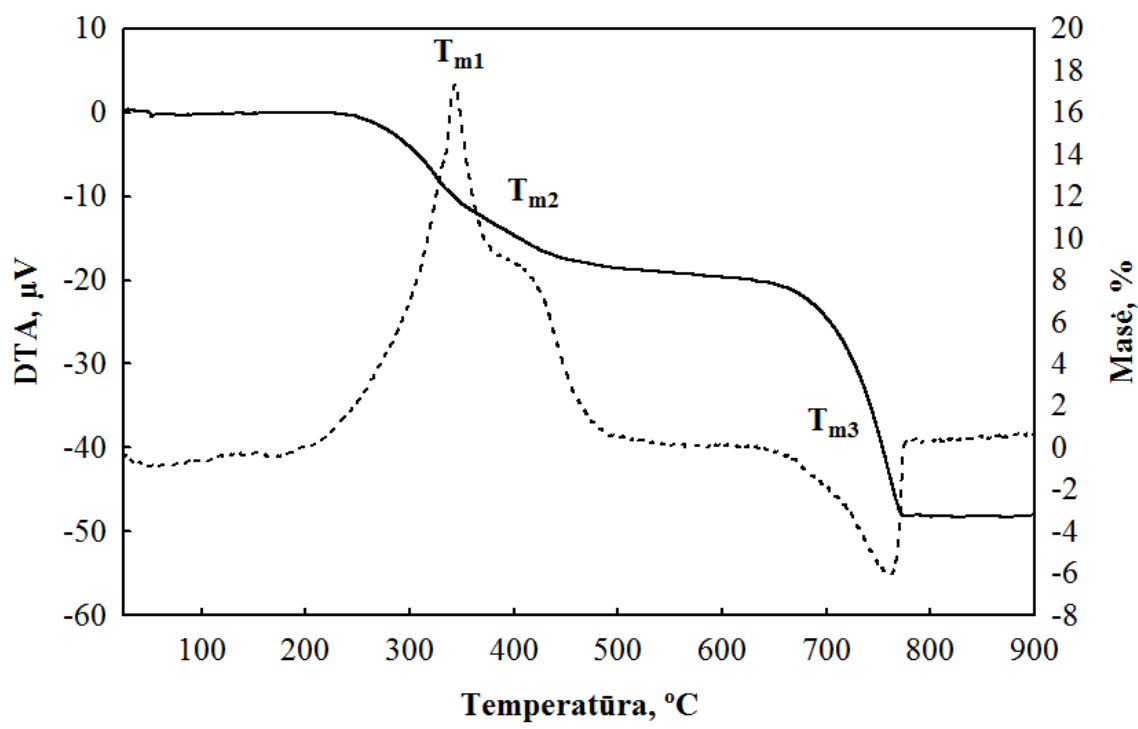

3.20 pav. Popieriaus gamybos atliekų dumblo dalelių, padengtų titanato jungiamąa medžiaga, termogravimetrinès ir diferencinès terminès analizių kreivès.

(- - -termogravimetrinès analizès kreivè, (--------) - diferencinès terminès analizès kreivè

Fig. 3.20. Curves of thermogravimetric and differential thermal analyses for paper production waste sludge particles coupled with titanate coupling agent.

$(-)$ - thermogravimetric analysis curve, (--------) - differential thermal analysis curve

PGAD dalelių diferencinès terminès analizès kreivè pasižymi dviem pagrindiniais egzoterminiais $\left(T_{m_{1}}\right.$ ir $\left.T_{m_{2}}\right)$ ir vienu endoterminiu $\left(T_{m_{3}}\right)$ efektais, esančiais, atitinkamai $200-350{ }^{\circ} \mathrm{C}, 360-470{ }^{\circ} \mathrm{C}$ ir $650-780^{\circ} \mathrm{C}$ temperatūrų intervaluose. Pirmajame egzoterminio intensyvumo $T_{m_{1}}$ intervale su maksimalia $342,1^{\circ} \mathrm{C}$ temperatūra dega PGAD dalelèse esanti organinè dalis, t. y. $200-280{ }^{\circ} \mathrm{C}$ vyksta celiuliozès dehidratacija, kuomet celiuliozė virsta bevandene celiulioze,

280-340 ${ }^{\circ} \mathrm{C}$ vyksta celiuliozès depolimerizacija, kurios metu formuojasi lakiosios medžiagos, $\left(\sim 320^{\circ} \mathrm{C}\right)$ bevandenè celiuliozė suyra ị dujas ir anglingąsias liekanas, $\left(\sim 319^{\circ} \mathrm{C}\right)$ suyra hemiceliuliozė ir $280-390^{\circ} \mathrm{C}$ lignine esančios polimerinès struktūros (Brebu, Vasile 2009). Antrasis egzoterminis efektas $T_{m_{2}}$ priskiriamas celiuliozès $\left(\sim 366{ }^{\circ} \mathrm{C}\right)$ makromolekulių atsiskyrimui ir tolimesniam lignino $400-440{ }^{\circ} \mathrm{C}$ terminiam irimui, kuomet formuojasi fenoliu produktai, kuriuose yra $-\mathrm{OH}$ grupių (fenoliai, hidroksifenoliai ir t.t.). Šių dviejų egzoterminių procesų metu $200-470{ }^{\circ} \mathrm{C}$ temperatūros intervale bandinys praranda $\sim 27,2 \%$ savo masès. Endoterminis 
efektas $650-780^{\circ} \mathrm{C}$ temperatūrų intervale su $756,3^{\circ} \mathrm{C}$ temperatūros maksimumu priskiriamas kalcio karbonato terminiam irimui pagal formulę (3.7), kurio metu bandinys praranda $\sim 3,6 \%$ savo masès.

$$
\mathrm{CaCO}_{3} \stackrel{{ }^{\circ} \mathrm{C}}{\rightarrow} \mathrm{CaO}+\mathrm{CO}_{2} \text {. }
$$

Galutinis anglingujų liekanų po bandymo kiekis - 50,6 \%. Akivaizdžiu poveikiu pasižymèjusių $20 \mathrm{dpm} \mathrm{RPG} \mathrm{ir} 10 \%$ bei $20 \%$ modifikuotų poliuretano putų terminio stabilumo bandymo metu gautų atitinkamų temperatūrų vertès pateiktos 3.10 lentelèje, TGA ir DTA kreivès $3.21 \mathrm{a}$ ir b paveiksluose.

3.10 lentelė. Propilenglikoliu ir popieriaus gamybos atliekų dumblo dalelèmis modifikuotų poliuretano putų terminio irimo temperatūrų vertès

Table 3.10. Values of thermal degradation temperatures for propylene glycol and paper production waste sludge particles modified polyurethane foam

\begin{tabular}{|l|c|c|c|}
\hline \multirow{2}{*}{ Parametras } & \multicolumn{3}{|c|}{ PGAD dalelių kiekis, masės \% } \\
\cline { 2 - 4 } & 0 & 10 & 20 \\
\hline$T_{p r},{ }^{\circ} \mathrm{C}$ & 286,2 & 284,0 & 282,9 \\
\hline$T_{m_{1}},{ }^{\circ} \mathrm{C}$ & 316,9 & 312,4 & 311,8 \\
\hline$T_{m_{2}},{ }^{\circ} \mathrm{C}$ & 479,9 & 471,2 & 459,2 \\
\hline$T_{m_{3}},{ }^{\circ} \mathrm{C}$ & 549,9 & 535,1 & 534,3 \\
\hline
\end{tabular}

3.21 b paveikslas rodo, kad bandiniai, veikiami didèjančia temperatūra, pasižymi vienu pagrindiniu maksimumu ( $T_{m_{3}}$ - trečioji stadija) ir dviem atbrailomis ( $T_{m_{1}}$ - pirmoji ir $T_{m_{2}}$ - antroji stadijos). Poliuretano putas sudaro tiek kietieji (izocianato ir RPG bei izocianato ir vandens reakcijos), tiek minkštieji segmentai (izocianato ir poliolio reakcija), todèl pirmoji stadija priskiriama kietujų segmentų, t. y. uretano ir urejja grupių, irimui, kurio metu atsiskiria izocianato ir RPG molekulès. Šių grupių irimas, kai PGAD dalelių kiekis $0 \%, 10 \%$ ir $20 \%$, yra, atitinkamai $228,0-331,4{ }^{\circ} \mathrm{C}, 234,9-324,6^{\circ} \mathrm{C}$ ir $240,3-318,4{ }^{\circ} \mathrm{C}$ temperatūru intervaluose. Pirmosios ir antrosios stadijų intensyvumai išreikšti labai nežymiai, nes šiuose temperatūrų intervaluose vyksta daug ịvairių ir persidengiančių ar vienas kitą papildančių procesų.

3.21 b paveiksle matomuose $223,8-366,8^{\circ} \mathrm{C}$ ir $212,5-369,4^{\circ} \mathrm{C}$ temperatūrų intervaluose, kuomet PGAD daleliu kiekis atitinkamai $10 \%$ ir $20 \%$, pastebimi $20,8 \%$ ir 21,5\% masès nuostoliai, priskiriami PGAD dalelèse esančios organinès dalies - celiuliozès, hemiceliuliozès ir lignino bei minètujų uretano $\left(\sim 200^{\circ} \mathrm{C}\right)$ ir urejja $200-250{ }^{\circ} \mathrm{C}$ grupių suirimui (McKenna, Hull 2016). 
a) 0

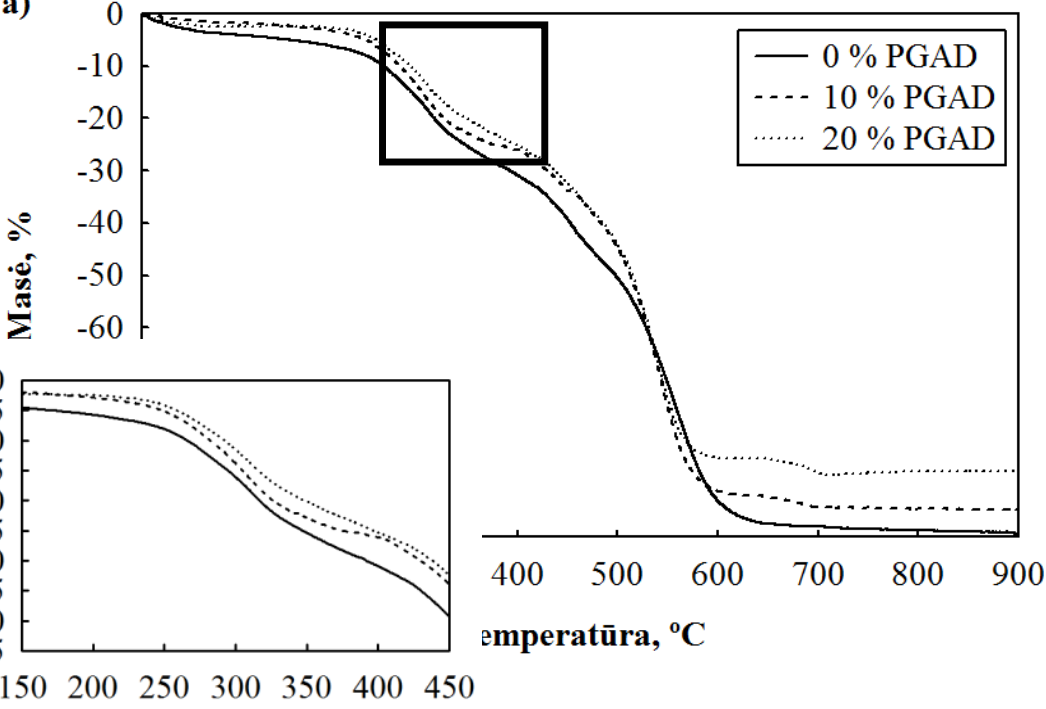

Temperatūra, ${ }^{\circ} \mathrm{C}$

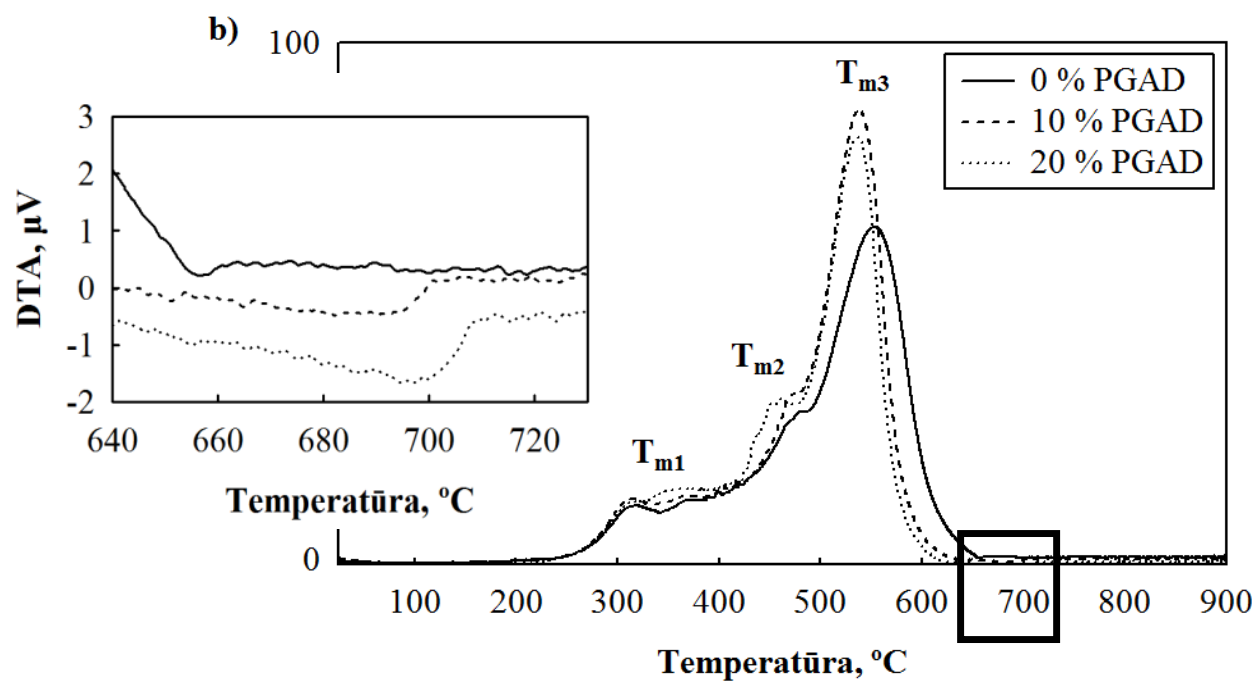

3.21 pav. Propilenglikoliu ir popieriaus gamybos atliekų dumblo dalelèmis modifikuotų poliuretano putų a) termogravimetrinès ir b) diferencinès terminés analizių kreivès

Fig. 3.21. Curves of a) thermogravimetric and b) differential thermal analyses for propylene glycol and paper production waste sludge particles modified polyurethane foam 
Taip pat šioje stadijoje, nuo $300{ }^{\circ} \mathrm{C}$, prasideda poliesterinių (minkštujų) segmentų irimas (Mondal, Hu 2007), kuomet vyksta poliesteriniai mainai, kurių metu susidaro cikliniai esterių oligomerai. Intervale nuo $363,0{ }^{\circ} \mathrm{C}$ iki $475,5^{\circ} \mathrm{C}$ kontrolinèse poliuretano putose su $T_{m_{2}}=479,9{ }^{\circ} \mathrm{C}$, nuo $398,3{ }^{\circ} \mathrm{C}$ iki $466,0^{\circ} \mathrm{C}$ su $T_{m_{2}}=471,2{ }^{\circ} \mathrm{C}$ ir nuo $380,1^{\circ} \mathrm{C}$ iki $457,2^{\circ} \mathrm{C}$ su $T_{m_{2}}=459,2{ }^{\circ} \mathrm{C}$, atitinkamai $10 \%$ ir $20 \%$ PGAD dalelèmis modifikuotose poliuretano putose vyksta izocianato disociacija ị karbodiimidą ir anglies dioksidą.

Trečioji stadija rodo visišką pagrindinių poliuretano putų grandžių suirimą temperatūrų intervale nuo $475,5^{\circ} \mathrm{C}$ iki $654,9^{\circ} \mathrm{C}$ kontrolinèms poliuretano putoms, nuo $466,0^{\circ} \mathrm{C}$ iki $638,3{ }^{\circ} \mathrm{C}$ ir nuo $457,2^{\circ} \mathrm{C}$ iki $614,8^{\circ} \mathrm{C}$, atitinkamai $10 \%$ ir $20 \%$ PGAD dalelėmis modifikuotoms poliuretano putoms. PGAD dalelëmis modifikuotų poliuretano putų $T_{m_{3}}$ maksimumų intensyvumai yra didesni nei kontrolinių poliuretano putų dèl lignino irimo, kurio smailių aukštis didejja priklausomai nuo PGAD dalelių kiekio poliuretano putose. Kitų autorių, tyrusių nemodifikuotų ir modifikutu poliuretano putu degumo charakteristikas, 1.9 poskyryje pateikti rezultatai rodo, kad PGAD dalelèmis modifikuotos poliuretano putos pasižymi ganètinai dideliu terminiu stabilumu, esant pastoviam kaitinimo greičiui.

\subsection{Trečiojo skyriaus išvados}

1. Pasiūlytas netiesinès regresijos modelis rodo, kad tariamojo tankio kitimą 95,8\% galima paaiškinti vandens kiekio (nuo $1 \mathrm{dpm}$ iki $6 \mathrm{dpm}$ ) pokyčiu $30,1-128,7 \mathrm{~kg} / \mathrm{m}^{3}$ tariamojo tankio ribose. Vertinant tariamojo tankio, pradinès susitraukties bei matmenų stabilumo $70^{\circ} \mathrm{C}$ temperatūros ir $90 \%$ santykinès drègmès aplinkoje vidutines vertes, modifikuotų poliuretano putu gamybai tikslinga naudoti $3,0 \mathrm{dpm}$ vandens.

2. Matmenų atžvilgiu stabilių poliuretano putų gamybai tinkamas grandinès plètiklis yra propilenglikolis iš rapsų glicerino, kuris dèl dalinai atviraporès struktūros formavimosi panaikina pradinę susitrauktị, sumažina procentinị tiesinių matmenų pokytị ilgio, pločio ir storio kryptimis iki MS(0,03/0,03/0,28), esant $10 \mathrm{dpm}$ kiekiui, iki $\operatorname{MS}(0,06 / 0,06 / 0,35)$, esant 15 dpm kiekiui ir iki MS(0,03/0,01/0,23), esant $20 \mathrm{dpm}$ kiekiui ir igalina gauti poliuretano putas, pasižyminčias termoizoliacinèms medžiagoms charakteringu tankiu, kintančiu nuo $40,7 \mathrm{~kg} / \mathrm{m}^{3} \mathrm{iki} 41,9 \mathrm{~kg} / \mathrm{m}^{3}$, bei sumažina gamybai skirtą laiką iki $133 \mathrm{~s}$, $124 \mathrm{~s}$ ir 118 s, kai RPG kiekis atitinkamai 10 dpm, 15 dpm ir 20 dpm. 
3. PGAD dalelių poveikio poliuretano putų tariamajam tankiui tyrimai parodè, kad pasiūlytas netiesinès regresijos modelis paaiškina tariamojo tankio kitimą, kurị 84,3 \% lemia RPG (nuo 10 dpm iki 20 dpm) ir PGAD dalelių (nuo $0 \%$ iki $20 \%$ ) kiekių pokytis. Gautas modelis taikytinas gaminiams, kurių tariamasis tankis kinta nuo $33,9 \mathrm{~kg} / \mathrm{m}^{3}$ iki $70,9 \mathrm{~kg} / \mathrm{m}^{3}$.

4. Didinant PGAD dalelių kieki nuo $5 \%$ iki $20 \%$ visose RPG modifikuotose sistemose, poliuretano putų gniuždymo stipris didèja, o tempimo stiprio vertès priklauso nuo PGAD dalelių ir poliuretano putu matricos sąveikos stiprumo, kuri lemia RPG kiekis.

5. Modifikuotų poliuretano putų šilumos laidumo koeficiento prognozavimui pasiūlytas netiesinès regresijos modelis paaiškina šilumos laidumo koeficiento kitimą, kuri 88,6\% lemia RPG (nuo $10 \mathrm{dpm}$ iki 20 dpm), PGAD dalelių (nuo $0 \%$ iki $20 \%$ ) kiekių ir išlaikymo po gamybos laikui nuo 1 dienos iki 28 dienų pokytis. Regresinẻ lygtis taikytina gaminiams, kurių šilumos laidumo koeficientas kinta nuo $0,0253 \mathrm{~W} /(\mathrm{m} \cdot \mathrm{K})$ iki $0,0359 \mathrm{~W} /(\mathrm{m} \cdot \mathrm{K})$.

6. PGAD dalelès sukelia papildomus tiesinių matmenų pokyčius $10 \mathrm{dpm}$ RPG modifikuotose poliuretano putose. $15 \mathrm{dpm}$ ir $20 \mathrm{dpm}$ RPG pradinę susitrauktị sumažino iki $0 \%$ nepriklausomai nuo PGAD dalelių kiekio, o matmenų stabilumo padidintos temperatūros ir drègmès aplinkoje rezultatai parode, kad gauti gaminiai atitinka standarto LST EN 13165 keliamus reikalavimus ( $\leq 1 \%$ ilgio, pločio ir $\leq 4 \%$ storio kryptimis).

7. RPG ir PGAD dalelėmis modifikuotų poliuretano putų drègminių savybių tyrimų metu nustatyta, kad:

- 10 dpm RPG ir nuo $0 \%$ iki $15 \%$ PGAD neturi reikšminio poveikio poliuretano putų vandens sugerties ir vandens garų varžos faktoriaus pokyčiui.

- 15 dpm ir 20 dpm RPG vidutiniškai padidina vandens sugertị ir vandens garų varžos faktorių atitinkamai nuo 6 \% iki 10\% ir nuo 40 iki 27.

- pasiūlytas netiesinès regresijos modelis paaiškina ilgalaikès vandens sugerties kitimą, kuri 85,5\% lemia RPG (nuo 10 dpm iki 20 dpm) ir PGAD daleliu (nuo $0 \%$ iki $20 \%$ ) kiekių pokytis. Gautas modelis taikytinas, kuomet ilgalaike vandens sugertis kinta nuo 4,95\% iki $10,3 \%$. 
8. PGAD dalelès, jų aglomeratai ir jose esančio $\mathrm{CaCO}_{3}$ vienas iš skilimo produktų $-\mathrm{CO}_{2}$ - slopina liepsnos plitimą bandinyje, lètindami anglingojo sluoksnio medžiagoje formavimąsi nuo $25 \mathrm{~s}$ iki $35 \mathrm{~s}$ ir sumažindami didžiausią šilumos išsiskyrimo greiti nuo $372 \mathrm{~kW} / \mathrm{m}^{2}$ iki $353 \mathrm{~kW} / \mathrm{m}^{2}$ bei anglies monoksido ir anglies dioksido kiekius atitinkamai $13,3 \%$ ir $29,5 \%$. 



\section{Bendrosios išvados}

1. Tariamojo tankio verčiu priklausomybè nuo vandens kiekio gali būti aprašoma regresine lygtimi, leidžiančia prognozuoti standžiųų poliuretano putų vidutines tariamojo tankio vertes vandens kiekiui kintant nuo $1,0 \mathrm{dpm}$ iki 6,0 dpm. Gaunami gaminiai pasižymi tariamuoju tankiu, kintančiu nuo $25,2 \mathrm{~kg} / \mathrm{m}^{3}$ iki $124 \mathrm{~kg} / \mathrm{m}^{3}$, pradine susitrauktimi ir matmenų stabilumu $70^{\circ} \mathrm{C}$ temperatūros ir $90 \%$ drègmès sąlygomis $(0,3 \leq \mathrm{MS} \leq 9) \%$ ilgio ir pločio bei $(0,5 \leq \mathrm{MS} \leq 16) \%$ storio kryptimis.

2. Matmenų atžvilgiu stabilių poliuretano putų iš rapsų aliejaus poliolių gamybai tikslinga naudoti nuo $10 \mathrm{dpm}$ iki $20 \mathrm{dpm}$ kiekius propilenglikolio iš rapsų glicerino, kuris lemia gaminius, pasižyminčius nuo $0 \%$ iki $0,8 \%$ ilgio ir pločio bei nuo $0,2 \%$ iki $1 \%$ storio kryptimis pradine susitrauktimi ir matmenų stabilumu $70{ }^{\circ} \mathrm{C}$ temperatūros ir $90 \%$ drègmès sąlygomis. Tokių gaminių tariamasis tankis kinta $40,7-42,1 \mathrm{~kg} / \mathrm{m}^{3}$ ribose, o gniuždymo stipris yra nuo $185 \mathrm{kPa}$ iki $197 \mathrm{kPa}$.

3. Titanato jungiamoji medžiaga, formuodama vienos molekulès dydžio sluoksni PGAD dalelès paviršiuje, sumažina mišinių dinaminę klampą vidutiniškai 2,3 karto, esant didžiausiam 20 \% PGAD dalelių kiekiui poliolio ir RPG mišinyje. 
4. PGAD dalelès formuoja dalinai uždaraporę, mažesnèmis akutėmis pasižyminčią, struktūrą ir lemia poliuretano putų iš rapsų aliejaus poliolių fizikines ir mechanines savybes. Gaunamos RPG ir PGAD modifikuotos matmenų atžvilgiu stabilios poliuretano putos, kurių tankis kinta $40-50 \mathrm{~kg} / \mathrm{m}^{3}$ ribose, gniuždymo stipris - nuo $193 \mathrm{kPa}$ iki $243 \mathrm{kPa}$, šilumos laidumo koeficientas $-0,0349 \mathrm{~W} /(\mathrm{m} \cdot \mathrm{K}) \quad$ iki $0,0359 \mathrm{~W} /(\mathrm{m} \cdot \mathrm{K})$, ilgalaikè vandens sugertis visiškai jame panardinus - nuo $6 \%$ iki $11 \%$ ir vandens garų varžos faktorius - nuo 26,2 iki 40,9.

5. Modifikuotas poliuretano putas veikiant atvira liepsna dèl nedegių medžiagu $\left(\mathrm{H}_{2} \mathrm{O}\right.$ ir $\left.\mathrm{CO}_{2}\right)$ išsiskyrimo PGAD dalelès ir jų aglomeratai atlieka barjero liepsnos plitimui ir staigiam šilumos išsiskyrimui funkciją, todèl gaminiai pasižymi lètesniu degimu. Kai poliuretano putose naudojamas $20 \%$ PGAD dalelių kiekis, šilumos išsiskyrimo greitis vidutiniškai sumažèja 5,1\%, anglies monoksido ir anglies dioksido kiekiai atitinkamai vidutiniškai sumažejja $13,3 \%$ ir $29,5 \%$. 


\section{Rekomendacijos}

1. Maišant žaliavų mišinị išpurškiamojo termoizoliacinio sluoksnio, sluoksnio sluoksniuotujjų konstrukcijų, plokščių su difuzijai nelaidžia danga ar be jos gamybai, rekomenduojamas komponentų A ir B santykis:

- kai poliolio mišinyje naudojamas $10 \mathrm{dpm}$ RPG ir 5\%, $10 \%, 15 \%$ ir $20 \%$ PGAD dalelių kiekiai, atitinkamai $(1: 1,4),(1: 1,2),(1: 1,1)$ ir $(1: 1)$;

- kai poliolio mišinyje naudojamas 15 dpm RPG ir 5\%, $10 \%, 15 \%$ ir $20 \%$ PGAD dalelių kiekiai, atitinkamai $(1: 1,6),(1: 1,3),(1: 1,2)$ ir $(1: 1,05)$;

- kai poliolio mišinyje naudojamas 20 dpm RPG ir 5\%, $10 \%, 15 \%$ ir $20 \%$ PGAD dalelių kiekiai, atitinkamai $(1: 1,7),(1: 1,5),(1: 1,3)$ ir $(1: 1,1)$.

2. Savybių atžvilgiu stabilaus termoizoliacinio sluoksnio iš poliuretano putų gamybai ir panaudojimui pastatų atitvarų šilumos izoliacijai tikslinga naudoti:

- nuo $5 \%$ iki $10 \%$ PGAD dalelių ir nuo 10 dpm iki 20 dpm RPG kiekius išpurškiamojo sluoksnio gamybai;

- nuo $5 \%$ iki $20 \%$ PGAD dalelių ir 15 dpm RPG kiekius standžiujų poliuretano putų su dujų difuzijai nelaidžia danga ir frezuotomis ịlaidomis bei sluoksniuotujų konstrukcijų gamybai;

- nuo $5 \%$ iki $20 \%$ PGAD dalelių ir nuo 15 dpm iki 20 dpm RPG kiekius standžiujjų poliuretano putų be dangos su frezuotomis įlaidomis gamybai. 



\section{Literatūra ir šaltiniai}

2006/12/EC (DEPC). 2006. Directive on Waste. Official Journal of the European Union. $13 \mathrm{p}$.

2008/98/EC (DW). 2008. Directive on Waste. Official Journal of the European Union. $28 \mathrm{p}$.

Agarry, S. E.; Latinwo, G. K.; Afolabi, T. J.; Kareem, S. A. 2015. Model predictive performance ofm filled flexible polyurethane foam, American Journal of Polymer Science 5(1): 1-9.

Ahmed, K. 2014. Synergistic effect of industrial waste in high density polyethylene, Journal of Materials and Environmental Science 5(3): 849-858.

Alam, M.; Akram, D.; Sharmin, E.; Zafar, F.; Ahmad, S. 2014. Vegetable oil based eco-friendly coating materials: a review article, Arabian Journal of Chemistry 7: 469-479.

Anderse, S. O.; Brack, D.; Depledge, J. 2014. A global response to HFCs through fair and effective ozone and climate policies. Chatham House. $50 \mathrm{p}$.

Arena, U. 2015. From waste-to-energy to waste-to-resources: the new role of thermal treatments of solid waste in the recycling society, Waste Management 37: 1-2.

ASTM D7487:2013 Standard practice for polyurethane raw materials: polyurethane foam cup test. West Conshohocken, 2013. 5 p.

Badri, K. H.; Ahmad, S. H.; Zakaria, S. 2001. Production of a high-functionality RBD palm kernel oil-based polyester polyol, Journal of Applied Polymer Science 81: 384-389. 
Badhe, Y.; Balasubramanian, K.; Singh, M.; Aswathy, A. 2015. Nano-engineered hybrid hydroxyapatite-grafted biocomposites for Euspria pulchella mimicking through chaotic flow regimes, RSC Advances 5(19): 14712-14719.

Bai, J.; Chaipanich, A.; Kinuthia, J. M.; O`Farell, M.; Sabir, B. B.; Wild, S.; Lewis, M. H. 2003. Compressive strength and hydration of wastepaper sludge ash-ground granulated blastfurnace slag blended pastes, Cement and Concrete Research 33(8): 1189-1202.

Bajpai, P. 2015. Management of Pulp and Paper Mill Waste, in: Bajpai P. Generation of waste in pulp and paper mills, Springer International Publishing, 9-17.

Banfill, P.; Frias, M. 2007. Rheology and conduction calorimetry of cement modified with calcined paper sludge, Cement and Concrete Research 37(2): 184-190.

Bao, T.; Chen, T.; Wille, M. L.; Chen, D.; You, S.; Bian, J.; Qing, C.; Wu, W.; Frost, R. L. 2016. Production of zeolite composite filters using waste paper pulpa s slow release carbon source and performance investigation in a biological aerated filtre, Journal of Water Process Engineering 9: 38-46.

Bolaji, B. O.; Huan, Z. 2013. Ozone depletion and global warming: case for the use of natural refrigerant - a review, Renewable and Sustainable Energy Reviews, 18: 49-54.

Brebu, M.; Vasile, C. 2009. Thermal degradation of lignin - a review, Cellulose Chemistry and Technology 44(9): 353-363.

Campanella, A.; Bonnaillie, L. M.; Wool, R. P. 2009. Polyurethane foams from soyoil-based polyols, Journal of Applied Polymer Science 112(4): 2567-2578.

Chen, H. B.; Wang, Y. Z.; Schiraldi, D. A. 2014. Preparation and flammability of poly(vinyl alcohol) composite aerogels, ACS Applied Materials and Interfaces 6(9): 6790-6796.

Choe, K. H.; Soo, D. L.; Seo, W. J.; Kim, W. N. 2004. Properties of rigid polyurethane foams with blowing agents and catalysts, Polymer Journal 36(5): 368-373.

Ciecierska, E.; Jurczyk - Kowalska, M.; Bazarnik, P.; Gloc, M.; Kulesza, M.; Kowalski, M.; Krauze, S.; Lewandowska, M. 2016. Flammability, mechanical properties and structure of rigid polyurethane foams with different types of carbon reinforcing materials, Composite Structures 140: 67-76.

Cusidó, J. A.; Cremades, L. V.; Soriano, C.; Devant, M. 2015. Incorporation of paper sludge in clay brick formulation: ten years of industrial experience, Applied Clay Science 108: 191-198.

Dai, C.; Zhang, C.; Huang, W.; Chang, K - C.; Lee, L. J. 2013. Thermoplastic polyurethane microcellular fibers via supercritical carbon dioxide based extrusion foaming, Polymer Engineering and Science, 53(11): 2360-2369.

Datta, J.; Głowińska, E. 2014. Effect of hydroxylated soybean oil and bio-based propanediol on the structure and thermal properties of synthesized bio-polyurethanes, Industrial Crops and Products 61: 84-91. 
David, J.; Vojtová, L.; Bednařík, K.; Kučerík, J.; Vávrová, M.; Jančař, J. 2009. Development of novel environmental friendly polyurethane foams, Environmental Chemistry Letters 8(4): 381-385.

Europos Sajungos Taryba (EST). 2006. ES darnaus vystymosi strategija: Pranešimas, Briuselis. Belgija. 29 p.

Espadas - Escalante, J. J.; Avilés, F.; Gonzalez - Chi, P. I.; Oliva, A. 2016. Thermal conductivity and flammability of multiwall carbon nanotube/polyurethane foam composites, Journal of Cellular Plastics 53(2): 215-230.

European Commission (EC). 2013. Best available techniques (BAT): Reference document for the production of pulp, paper and board, Institute for Prospective Technological Studies, Seville, Spain. 506 p.

Fan, H.; Tekeei, A.; Suppes, G. J.; Hsieh, F. H. 2012. Physical properties of soy-phosphate polyol-based rigid polyurethane foam, International Journal of Polymer Science 2012: 1-8.

Feinle, A.; Hüsing, N. 2015. Mixed metal oxide aerogels from tailor-made precursors, The Journal of Supercritical Fluids 106: 2-8.

Feng, F.; Qian, L. 2014. The flame retardant behaviors and synergistic effect of expandable graphite and dimethyl methylphosphonate in rigid polyurethane foams, Polymer Composites 35(2): 301-309.

Ferrándiz - Mas, V.; Bond, T.; García - Alcocel, E.; Cheeseman, C. R. 2014. Lightweight mortars containing expanded polystyrene and paper sludge ash, Construction and Building Materials 61: 285-292.

Ferreiro, S.; Blasco, T.; Sánchez de Rojas, M. I.; Frias, M. 2009. Influence of activated art paper sludge-lime ratio on hydration kinetics and mechanical behavior in mixtures cured at $20^{\circ} \mathrm{C}$, Journal of the American Ceramic Society 92(12): 3014-3021.

Fieback, T.; Michaeli, W.; Latz, S.; Mondéjar, M. E. 2011. Sorption and swelling measurements of $\mathrm{CO}_{2}$ and $\mathrm{N}_{2}$ on polyol for their use as blowing agents in a new PU foaming process device, Industrial and Engineering Chemistry Reasearch, 50(12): 7631-7636.

Firdaus, F. E. 2011. Chain extender on property relationships of polyurethane derived from soybean oil, International Journal of Chemical, Molecular, Nuclear, Materials and Metallurgical Engineering 5(9): 758-761.

Frías, M.; García, R.; Vigil, R.; Ferreiro, S. 2008. Calcination of art paper sludge waste for the use as a supplementary cementing material, Applied Clay Science 42(2): 189-193.

Frías, M.; Rodríguez, O.; Sánchez de Rojas, M. I. 2015. Paper sludge, an environmentally sound alternative source of MK-based cementitious materials. A review, Construction and Building Materials 74: 37-48.

Frías, M.; Vigil, R.; García, R.; Rodríguez, O.; Goñi, S.; Vegas, I. 2012. Evolution of mineralogical phases produced during the pozzolanic reaction of different metakaolinite by-products: influence of the activation process, Applied Clay Science 56: 48-52. 
Fridrihsone, A.; Stirna, U.; Lazdina, B.; Misane, M.; Vilsone, D. 2013. Characterization of polyurethane networks structure and properties based on rapeseed oil derived polyol, European Polymer Journal 46: 1204-1214.

Gallardo, F.; Bravo, C.; Briceño, G.; Diez, M. C. 2010. Use of sludge from kraft mill wastewater treatment as improver of volcanic soils: effect on soil biological parameters, Journal of Plant Nutrition and Soil Science 10(1): 48-61.

Gallardo, F.; Cea, M.; Tortella, G. R.; Diez, M. C. 2012. Effect of pulp mill sludge on soil characteristics, microbial community and vegetal productionof lolium perenne, Journal of Environmental Management 95: 193-198.

Galvão, A. C. P.; Farias, A. C. M.; Mendes, J. U. I. 2015. Characterization of waste of soda-lime glass generated from lapping process to reuse as filler in composite materials as thermal insulation, Cerâmica 61: 367-373.

García, T.; Vigil de la Villa, T.; Vegas, I.; Frías, M.; Sánchez de Rojas, M. I. 2008. The pozzolanic properties of paper sludge waste, Construction and Building Materials 22: 1484-1490.

General Assembly. 2015. Transforming our world: the 2030 agenda for sustainable development: New York, USA. 35 p.

Głowińska, E.; Datta, J. 2015. Structure, morphology and mechanical behaviour of novel bio-based polyurethane composites with microcrystalline cellulose, Cellulose 22(4): 2471-2481.

Głowińska, E.; Datta, J. 2016. Bio polyurethane composites with high content of natural ingredients: hydroxylated soybean oil based polyol, bio glycol and microcrystalline cellulose, Cellulose 23(1): 581-592.

Gluth, G. J. G.; Lehmann, C.; Rübner, K.; Kühne, H. C. 2014. Reaction products and strength development of wastepaper sludge ash and the influence of alkalis, Cement and Concrete Composites 45: 82-88.

Grolier, J - P. E.; Randzio, S. L. 2012. Simple gases to replace non-environmentally friendly polymerfoaming agents. A thermodynamic investigation, The Journal of Chemical Thermodynamics, 46: 42-56.

Gu, R.; Sain, M. M. 2013. Effects of wood fiber and microclay on the performance of soy based polyurethane foams, Journal of Polymers and the Environment 21(1): 30-38.

Guler, T.; Tayfun, U.; Bayramli, E.; Dogan, M. 2017. Effect of expandable graphite on flame retardant, thermal and mechanical properties of thermoplastic polyurethane composites filled with huntite\&hydromagnesite mineral, Thermochimica Acta 647: 70-80.

Guo, A.; Demydov, D.; Zhang, W.; Petrovic, Z. S. 2002. Polyols and polyurethanes from hydroformylation of soybean oil, Journal of Polymers and the Environment 10: 49-52.

Guo, A.; Javni, I.; Petrovic, Z. 2000. Rigid polyurethane foams based on soybean oil, Journal of Applied Polymer Science 77(2): 467-473. 
Gupta, R. K.; Ionescu, M.; Wan, X.; Radojcic, D.; Petrović, Z. S. 2015. Synthesis of novel limonene based mannich polyol for rigid polyurethane foams, Journal of Polymers and the Environment 23: 261-268.

Gupta, R. K.; Ionescu, M.; Wan, X.; Radojcic, D.; Petrović, Z. S. 2014. Novel renewable polyols based on limonene for rigid polyurethane foams, Journal of Polymers and the Environment 22: 304-309.

Haddar, M.; Elloumi, A.; Koubaa, A.; Bradai, C.; Migneault, S.; Elhalouani, F. 2016. Effect of high content of deinking paper sludge (DPS) on the reinforcement of HDPE, Journal of Polymers and the Environment 25(3): 617-627.

Han, M. S.; Choi, S. J.; Kim, J. M.; Kim, Y. H.; Kim, W. N. 2009. Effect of silicone surfactant on the cell size and thermal conductivity of rigid polyurethane foams by environmentally friendly blowing agents, Macromolecular Research 17(1): 44-50.

Han, M. S.; Kim, Y. H.; Han, S. J.; Choi, S. J.; Kim, S. B.; Kim, W. N. 2008. Effects of a silane coupling agent on the exfoliation of organoclay layers in polyurethane/organoclay nanocomposite foams?, Journal of Applied Polymer Science 110: 376-386.

Harrison, M. W. 1990. Statistical methods for engineers and scientists. Teksasas: Mcgrew - Hill. 640 p.

Hatakeyama, H.; Marusawa, T.; Hatakeyama, T. 2011. Soft-type polyurethane foams derived from molasses, Journal of Materials Science 46(23): 7475-7481.

Hejna, A.; Kirpluks, M.; Kosmela, P.; Cabulis, U.; Haponiuk, J.; Piszczyk, Ł. 2017. The influence of crude glycerol and castor oil-based polyol on the structure and performance of rigid polyurethane-polyisocianurate foams, Industrial Crops and Products 95: 113-125.

Hong, J. Y.; Sohn, E. H.; Park, S.; Park, H. S. 2015. Highly-efficient and recyclable oil absorbing performance of functionalized graphene aerogel, Chemical Engineering Journal 269: 229-235.

Hsiang, H. I.; Chen, C. C.; Tsai, J. Y. 2005. Dispersion of nonaqueous $\mathrm{Co}_{2} \mathrm{Z}$ ferrite powders with titanate coupling agent and poly(vinyl butyral), Applied Surface Science 245: 252-259.

Huang, P.; Fan, M. 2016. Development of facture free clay-based aerogel: formulation and architectural mechanisms, Composites Part B: Engineering 91: 169-175.

Ionescu, M. 2005. Chemistry and technology of polyols for polyurethane. Shawbury: Rapra technology limited. $605 \mathrm{p}$.

Ionescu, M.; Wan, X.; Bilic, N.; Petrovic, Z. S. 2012. Polyols and rigid polyurethane foams from cashew nut shell liquid, Journal of Polymers and the Environment 20: 647-658.

ISO 5660-1:2015 Reaction to fire tests - heat release, smoke production and mass loss rate - part 1: heat release rate (cone calorimeter method) and smoke production rate (dynamic measurement). Geneva, 2015. 55 p. 
Janik, H.; Sienkiewicz, M.; Kucinska - Lipka, J. 2014. Polyurethanes, in: Handbook of thermoset plastics, third ed., Elsevier, 253-295.

Jarfelt, U.; Ramnäs, O. 2006. Thermal conductivity of polyurethane foam - bets performance, $10^{\text {th }}$ International Symposium on District Heating and Cooling: September 3-5, 2006, Göteborg, Sweden.

Jiao, C.; Zhao, X.; Song, W.; Chen, X. 2015. Synergistic flame retardant and smoke suppression effects of ferrous powder with amonium polyphosphate in thermoplastic polyurethane composites, Journal of Thermal Analysis and Calorimetry 120: 1173-1181.

Jin, C.; Han, S.; Li, J.; Sun, Q. 2015. Fabrication of cellulose-based aerogels from waste newspaper without any pretreatment and their use for absorbents, Carbohydrate Polymers 123: $150-156$.

Kango, S.; Kalia, S.; Celli, A.; Njuguna, J.; Habibi, Y.; Kumar, R. 2013. Surface modification of inorganic particles for development of organic-inorganic nanocomposites - A review, Progress in Polymer Science 38: 1232-1261.

Kausar, A. 2014. Poly(methyl methacrylate)/poly(urethane-urea)-based nanocellular foams reinforced with kaolin, Journal of Composite Materials 0(0): 1-10.

Kim, C.; Youn, J. R. 2000. Environmentally friendly processing of polyurethane foam for thermal insulation, Polymer - Plastics Technology and Engineering, 39(1): 163-185.

Kim, S. H.; Kim, B. K. 2008. Effect of isocyanate index on the properties of rigid polyurethane foams blown by HFC 365mfc, Macromolecular Research 16(5): 467-472.

Kingston, C.; Zepp, R.; Andrady, A.; Boverhof, D.; Fehir, R.; Hawkins, D.; Roberts, J.; Sayre, P.; Shelton, B.; Sultan, Y.; Vejins, V.; Wohlleben, W. 2014. Release characteristics of selected carbon nanotube polymer composites, Carbon 68: 33-57.

Kirpluks, M.; Cabulis, U.; Avots, A. 2016. Flammability of bio-based rigid polyurethane foam as sustainable thermal insulation material in: Insulation Materials on Context of Sustainability, Intech, 85-106.

Kirpluks, M.; Cabulis, U.; Kurańska, M.; Prociak, A. 2013. Three different approaches for polyol synthesis from rapeseed oil, Key Engineering Materials 559: 69-74.

Kong, X.; Liu, G.; Qi, H.; Curtis, J. M. 2013. Preparation and characterization of high-solid polyurethane coating systems based on vegetable oil derived polyols, Progress in Organic Coatings 76: 1151-1160.

Kurańska, M.; Cabulis, U.; Auguścik, M.; Prociak, A.; Ryszkowska, J.; Kirpluks, M. 2016. Bio-based polyurethane-polyisocianurate composites with an intumescent flame retardant, Polymer Degradation and Stability 127: 11-19.

Kurańska, M.; Prociak, A. 2015. Flax fibres as natural filler for rigid polyurethane-polyisocianurate foams based on bio-polyol from rapeseed oil, Technical Transactions 112: 47-54.

Kurańska, M.; Prociak, A. 2016. The influence of rapeseed oil-based polyols on the foaming process of rigid polyurethane foams, Industrial Crops and Products 89: 182-187. 
Kurańska, M.; Prociak, A.; Cabulis, U.; Kirpluks, M.; Ryszkowska, J.; Auguścik, M. 2017. Innovative porous polyurethane-polyisocyanurate foams based on rapeseed oil and modified with expandable graphite, Industrial Crops and Products 95: 316-323.

Kwon, O. J.; Oh, S. T.; Lee, S. D.; Lee, N. R.; Shin, C. H.; Park, J. S. 2007. Hydrophilic and flexible polyurethane foams using sodium alginate as polyol: effects of PEG molecular weight and cross-linking agent content on water absorbency, Fibers and Polymers 8(4): 347-355.

Lan, Z.; Daga, R.; Whitehouse, R.; McCarhy, S.; Schmidt, D. 2014. Structure - properties relationsin flexible polyurethane foams containing a novel bio-based crosslinker, Polymer, 55(11): 2635-2644.

Lapprand, A.; Boisson, F.; Delolme, F.; Méchin, F.; Pascault, J. P. 2005. Reactivity of isocyanates with urethanes: conditions for allophanate formation, Polymer Degradation and Stability 90(2): 363-373.

Latinwo, G. K.; Aribike, D. S.; Oyekunle, L. O.; Susu, A. A.; Kareem, S. A. 2010. Effects of calcium carbonate of different compositions and particle size distributions on the mechanical properties of flexible polyurethane foam, Nature and Science 8(9): 92-101.

Lee, J. M.; Kim, S. H.; Jeong, H. Y.; Ahn, N. R.; Roh, H. G.; Cho, J. W.; Chun, B. C.; Oh, S. T.; Park, J. S. 2014. Preparation and characterization of polyurethane foam using a PLA/PEG polyol mixture, Fibers and Polymers 15(7): 1349-1356.

Li, Y.; Luo, X.; Hu, S. 2015. Polyols and polyurethanes from vegetable oils and their derivatives, Springer International Publishing: New York, USA.

Li, W.; Ryan, A. J. 2002. Effect of chain extenders on the morphology development in flexible polyurethane foam, Macromoleculaes 35: 6306-6312.

Lietuvos Respublikos Vyriausybè (LRV). 2011. Dèl nacionalinès darnaus vystymosi strategijos patvirtinimo ir igyvendinimo: Nutarimas su 2011 m. pakeitimais, Vilnius, Lietuva. $85 \mathrm{p}$.

Lim, H.; Kim, S. H.; Kim, B. K. 2008. Effect of silicone surfactant in rigid polyurethane foams, Express Polymer Letters 2(3): 194-200.

Lin, Y.; Hsieh, S.; Huff, H. E. 1997. Water-blown flexible polyurethane foam extended with biomass materials, Applied Polymer Science 65(4): 695-703.

Lin, Y.; Zhou, S.; Li, F.; Lin, Y. 2012. Utilization of municipal sawage sludge as additive for the production of eco-cement, Journal of Hazardous Materials 213-214: 457-465.

Log, Y.; Zheng, L.; Gu, Y.; Lin, H.; Xie, X. 2014. Carbon dioxide adduct from polypropylene glycol grafted polyethyleneimine as a climate-friendly blowing agent for polyurethane foams, Polymer, 55(25): 6494-6503.

LST EN 1097-3:2002 Užpildu mechaninių ir fizikinių savybiu nustatymo metodai. 3 dalis. Piltinio tankio ir tuštymètumo nustatymas. Vilnius, 2002. 14 p.

LST EN 12085:2013 Statybiniai termoizoliaciniai gaminiai. Bandinių ilginių matmenu nustatymas. Vilnius, 2013.9 p. 
LST EN 12086:2013 Statybiniai termoizoliaciniai gaminiai. Pralaidumo vandens garui nustatymas. Vilnius, 2013. 17 p.

LST EN 12087:2013 Statybiniai termoizoliaciniai gaminiai. Ilgalaikès vandens sugerties panardinus jame nustatymas. Vilnius, 2013. 13 p.

LST EN 12667:2002 Šiluminès statybinių medžiagu ir gaminių savybès. Šiluminès varžos nustatymas apsaugotos karštosios plokštès ir šilumos srauto matuoklio metodais. Didelès ir vidutinès šiluminès varžos gaminiai. Vilnius, 2002. 42 p.

LST EN 13820:2004/P:2006 Statybinès termoizoliacinès medžiagos. Organinès dallies nustatymas. Vilnius, $2006.9 \mathrm{p}$.

LST EN 1602:2013 Statybiniai termoizoliaciniai gaminiai. Tariamojo tankio nustatymas. Vilnius, 2013. 8 p.

LST EN 1604:2013 Statybiniai termoizoliaciniai gaminiai. Matmenu stabilumo nurodytomis temperatūros ir drégmès sąlygomis nustatymas. Vilnius, 2013. 10 p.

LST EN 1607:2013 Statybiniai termoizoliaciniai gaminiai. Statmeno paviršiams tempimo stiprio nustatymas. Vilnius, 2013. 10 p.

LST EN 196-6:2010 Cemento bandymo metodai. 6 dalis. Smulkumo nustatymas. Vilnius, 2010. 18 p.

LST EN 826:2013 Statybiniai termoizoliaciniai gaminiai. Elgsenos gniuždant nustatymas. Vilnius, 2013. 13 p.

LST EN ISO 4590:2016 Standieji akytieji plastikai. Atvirujų ir uždarujų akučiu procentinès tūrio dallies nustatymas. Vilnius, 2016. 24 p.

LT EN ISO 11925-2:2010 Reakcijos ị ugni bandymai. Gaminiu užsidegamumas tiesiogiai veikiant liepsna. 2 dalis. Bandymas pavieniu liepsnos šaltiniu. Vilnius, 2010. 30 p.

Ma, S. R.; Shi, L. Y.; Feng, X.; Yu, W. J.; Lu, B. 2005. Graft modification of ZnO nanoparticles with silane coupling agent KH570 in mixed solvent, Journal of Shanghai University 12: $278-282$.

Madbouly, S. A.; Zhang, C.; Kessler, M. R. 2016. Bio-based plant oil polymers and composites. Oxford: Elsevier. 2017 p.

Marhoon, I. I. 2016. Effect of silica-fume microparticles on rigid polyurethane foam properties, International Journal of Scientific and Technology Research 5(7): 96-100.

Martínez, C.; Cotes, T.; Corpas, F. A. 2012. Recovering wastes from the paper industry: development of ceramic materials, Fuel Processing Technology 103: 117-124.

McKenna, S. T.; Hull, T. R. 2016. The fire toxicity of polyurethane foams, Fire Science Reviews 5(3): 1-27.

Melo, C. R.; Angioletto, E.; Riella, H. G.; Peterson, M.; Rocha, M. R.; Melo, A. R.; Silva, L.; Strugale, S. 2012. Production of metakaolin from industrial cellulose waste, Journal of Thermal Analysis and Calorimetry 109(3): 1341-1345. 
Miao, S.; Wang, P.; Su, Z.; Zhang, S. 2014. Vegetable-oil-based polymers as future polymeric biomaterials, Acta Biomaterialia 10: 1692-1704.

Modesti, M.; Lorenzetti, A. 2002. Halogen-free retardant for polymeric foams, Polymer Degradation and Stability 78(1): 167-173.

Mondal, S.; Hu, J. L. 2007. Influence of hard segment on thermal degradation of thermoplastic segmented polyurethane for textile coating application, Polymer-Plastics Technology and Engineering 46: 37-41.

Mosiewicki, M. A.; Dell'Arciprete, G. A.; Aranguren, M. I.; Marcovich, N. E. 2009. Polyurethane foams obtained from castor oil-based polyol and filed with wood flour, Journal of Composite Materials 43(25): 3057-3072.

Motahari, S.; Motlagh, G. H.; Moharramzadeh, A. 2015. Thermal and flammability properties of polypropylene/silica aerogel composites, Journal of Macromolecular Science, Part B 54(9): 1081-1091.

Mozaffari, E.; O`Farell, M.; Kinuthia, J. M.; Wild, S. 2006. Improving strength development of wastepaper sludge ash by wet-milling, Cement and Concrete Composites 28(2): 144-152.

Mullin, J. W. 2001. Crystallization, Butterworth-Heinemann: Oxford, England. 594 p.

Mun, S. P.; Ahn, B. J. 2001. Chemical conversion of paper sludge incineration ash into synthetic zeolite, Journal of Industrial and Engineering Chemistry 7(5): 292-298.

Narine, S. S., Kong, Z., Bouzidi, L., Sporns, P. 2007. Physical properties of polyurethanes produced from polyols from seed oils: II. Foams, Journal of the American Oil Chemists ' Society 84: 65-72.

Nunez, E. E., Polychronopoulou, K., Polycarpou, A. A. 2010. Lubricity effect of carbon dioxide used as environmentally friendly refrigerant in air-conditioning and refrigeration compresorrs, Wear 270: 46-56.

Oh, S. T.; Kim, W. R.; Kim, S. H.; Chung, Y. C.; Park, J. S. 2011. The preparation of polyurethane foamcombined with $\mathrm{pH}$-sensitive alginate/bentonite hydrogel for wound dressing, Fibers and Polymers 12(2): 159-165.

Park, D. H.; Park, G. P.; Kim, S. H.; Kim, W. N. 2013. Effects of isocianate index and environmentally-friendly blowing agents on the morphological, mechanical, and thermal insulating properties of polyisocyanurate-polyurethane foams, Macromolecular Research 21(8): 852-859.

Pawar, M. S.; Kadam, A. S.; Singh, P. C.; Kusumkar, V. V.; Yemul, O. S. 2016. Rigid polyurethane foams from cottonseed oil using bio-based chain extenders: a renewable approach, Iranian Polymer Journal 25: 59-68.

Pawlik, K.; Prociak, A. 2011. Influence of pal oil-based polyol on the properties of flexible polyurethane foams, Journal of Polymers and the Environment 20(2): 438-445. 
Peyronnard, O.; Benzaazoua, M. 2011. Estimation of the cementitious properties of various industrial by-products for applications requiring low mechanical strength, Resources, Conservation and Recycling 56(1): 22-33.

Pillai, P. K. S.; Li, S.; Bouzidi, L.; Narine, S. S. 2016. Metathesized palm oil: fractionation strategies for improving functional properties of lipid-based polyols and derived polyurethane foams, Industrial Crops and Products 84: 273-283.

Pratondo, E.; Hanggoro, A. W.; Ningrum, E. O.; Sumarno. 2012. Effect of chain extender to the structure of castor oil-based polyurethane foam, in Proceeding of International Conference on Chemical and Material Engineering V:1: 1-5.

Preston, S. 2000. Teaching prediction intervals, Journal of Statistics Educations 8(3): $1-4$

Rada, E. C.; Ragazzi, M.; Ionescu, G.; Merler, G.; Moedinger, F.; Raboni, M.; Torretta, V. 2014. Municipal solid waste treatment by integrated solutions: energy and environmental balances, Energy Procedia 50: 1037-1044.

Randall, D.; Lee, S. 2010. The polyurethanes book. New York: Willey. 494 p.

Rashmi, B. J.; Rusu, D.; Prashantha, K.; Lacrampe, M. F.; Krawcak, P. 2013. Development of bio-based thermoplastic polyurethane formulations using corn-derived chain extender for reactive rotational molding, eXPRESS Polymer Letters 7(10): 852-862.

Rivera, J. A.; López, V. P.; Casado, R. R.; Hervás, J. M. S. 2016. Thermal degradation of paper industry wastesfrom a recovered paper mill using TGA. Characterization and gasification test, Waste Management 47: 225-235.

Rojek, P.; Prociak, A. 2012. Effect of different rapeseed-oil-based polyols on mechanical properties of flexible polyurethane foams, Journal of Applied Polymer Science 125(4): 2936-2945.

Sá e Sant'Anna, S.; Arlindo de Souza, D.; Marques de Araujo, D.; Carvalho, C. F.; Yoshida, M. I. 2008. Physico-chemical analysis of flexible polyurethane foams containing commercial calcium cabonate, Materials Research 11(4): 433-438.

Sabzi, M.; Mirabedini, S. M.; Zohuriaan - Mehr, J.; Atai, M. 2009. Surface modification of $\mathrm{TiO}_{2}$ nano-particles with silane coupling agent and investigation of its effect on the properties of polyurethane composite coating, Progress in Organic Coatings 65: 222-228.

Sakalauskas, V. 2003. Duomenu analizè su Statistica. Vilnius: Margi raštai. 235 p.

Savas, L. A.; Deniz, T. K.; Tayfun, U.; Dogan, M. 2017. Effect of microcapsulated red phosphorus on flame retardant, thermal and mechanical properties of thermoplastic polyurethane composites filled with huntite\&hydromagnesite mineral, Polymer Degradation and Stability 135: 121-129.

Segev, O.; Kushmaro, A.; Brenner, A. 2009. Environmental impact of flame retardants (persistence and biodegrability), International Journal of Environmental Research and Public Health 6(2):478-491. 
Segui, P.; Aubert, J. E.; Husson, B.; Measson, M. 2012. Characterization of wastepaper sludge ash for its valorization as a component of hydraulic binders, Applied Clay Science 57: 79-85.

Seo, W. J.; Jung, H. C.; Hyun, J. C.; Kim, W. N.; Lee, Y. B.; Choe, K. H.; Kim, S. B. 2003. Mechanical, morphological and thermal properties of rigid polyurethane foams blown by distilled water, Journal of Applied Polymer Science 90: 12-21.

Septevani, A. A.; Evans, D. A. C.; Chaleat, C.; Martin, D. J.; Annamalai, P. K. 2015. A systematic study substituting polyether polyol with palm kernel oil based polyester polyol in rigid polyurethane foam, Industrial Crops and Products 66: 16-26.

Shams, A.; Stark, A.; Hoogen, F.; Hegger, J.; Schneider, H. 2015. Innovative sandwich structures made of high performance concrete and foamed polyurethane, Composite Structures 121: 271-279.

Shen, X.; Gui, S.; Lin, B. 2006. Surface organic modification of $\mathrm{Fe}_{2} \mathrm{O}_{4}$ nanoparticles by silane-coupling agents, Rare Metals 25: 426-430.

Singh, H.; Sharma, T. P.; Jain, A. K. 2007. Reactivity of the raw materials and their effects on the structure and properties of rigid polyurethane foams, Journal of Applied Polymer Science 106(2): 1014-1023.

Sipaut, C. S.; Ahmad, N.; Adnan, R.; Rahman, I. A.; Ibrahim, M. N. M. 2010. Effects of starting material and reaction temperature on the morphology and physical properties of polyurethane foams, Cellular Polymers 29(1): 1-25.

Sonnenschein, M. F.; Wendt, B. L. 2013. Design and formulation of soybean oil derived flexible polyurethane foams and their underlying polymer structure/property relationships, Polymer 54: 2511-2520.

Statista. 2016. Global production of vegetable oils from 2000/01 to 2015/16. 1 p. [Žiūrèta 2016-06-01]. Prieiga per internetą: http://www.statista.com/statistics/263978/global-vegetable-oil-production-since-2000-2001/.

Stirna, U.; Cabulis, U. 2008. Water-blown polyisocyanurate foams from vegetable oil polyols, Journal of Cellular Plastics 44: 139-160.

Stirna, U.; Sevastyanova, I.; Misane, M.; Cabulis, U.; Beverte, I. 2006. Structure and properties of polyurethane foams obtained from rapeseed oil polyols, in: Proceedings of the Estonian Academy of Sciences. Chemistry V. 55: 101-110.

Šulcienė, M.; Karalius, A.; Matijošytė, I. 2014. Chemo-enzymatic route for the production of biopolyol from rapeseed oil, Current Organic Chemistry 18: 3037-3043.

Sun, H.; Xu, Z.; Gao, C. 2013. Multifunctional, ultra-flyweight, synegistically assembled carbon aerogels, Advanced Materials 25(18): 2554-2560.

Sutcu, M.; Akkurt, S. 2009. The use of recycled paper processing residues in making porous brick with reduced thermal conductivity, Ceramics International 35(7): 2625-2631.

Szycher, M. 2012. Handbook of polyurethanes, CRC Press: New York, USA. 696 p. 
Tan, S.; Abraham, T.; Ference, D.; Macosko, C. W. 2011. Rigid polyurethane foam from a soybean oil-based polyol, Polymer 52: 2840-2846.

Tanaka, R.; Hirose, S.; Hatakeyama, H. 2008. Preparation and characterization of polyurethane foams using a palm oil-based polyol, Bioresource Technology 99(9): 3810-3816.

Tang, G. H.; Bi, C.; Zhao, Y.; Tao, W. Q. 2015. Thermal transport in nano-porous insulation of aerogel: factors, models and outlook, Energy 90(1): 701-721.

Tawfik, M.; Ahmed, N.; Ward, A. 2013. Characterization of kaolin-filled polymer composites, Society of Plastics Engineers: SPE Plastics Research 1: 1-3.

Tayfun, U.; Dogan, M.; Bayramli, E. 2015. Investigations of the flax fiber/thermoplastic polyurethane eco-composites: influence of isocyanate modification of flax fiber surface, Polymer Composites 0(0): 00-00. [Žiūrèta 2017-08-21].

Prieiga per internetą: http://dx.doi.org/10.1002/pc.23889

Tham, W. L.; Chow, W. S.; Ishak, Z. A. M. 2011. Effects of titanate coupling agent on the mechanical, thermal, and morphological properties of poly(methyl methacrylate)/hydroxyapatite denture base composites, Journal of Composite Materials 45(22): 2335-2345.

Thirumal, M.; Khastgir, D.; Singha, N. K.; Manjunath, B. S.; Naik, Y. P. 2008. Effect of foam density on the properties of water blown rigid polyurethane foam, Journal of Applied Polymer Science 108: 1810-1817.

Tien, Y. I.; Wei, K. H. 2002. The effect of nano-sized silicate layers from montmorillonite on glass transition, dynamic mechanical, and thermal degradation properties of segmented polyurethane, Journal of Applied Polymer Science 86(7): 1741-1748.

Toya, T.; Kameshima, Y.; Nakajima, A.; Okada, K. 2006. Preparation and properties of glass-ceramics from kaolin clay refining waste (Kira) and paper sludge ash, Ceramics International 32(7): 789-796.

Tu, Y. C.; Fan, H.; Suppes, G. J.; Hsieh, F. H. 2009. Physical properties of water-blown rigid polyurethane foamscontaining epoxidized soybean oil in different isocyanate indices, Journal of Applied Polymer Science 114(5): 2577-2583.

Tuckett, R. P. 2016. The role of atmospheric gases, in: Climate change. Observed impacts on planet earth 2 nd edition, 375-397.

United Nations (UN). 1998. Kyoto protocol to the united nations framework convention on climate change. United Nations. $21 \mathrm{p}$.

Usman, M. A.; Adeosun, S. O.; Osifeso, G. O. 2012. Optimum calcium carbonate filler concentration for flexible polyurethane foam composite, Journal of Minerals and Materials Characterization and Engineering 11(3): 311-320.

Vegas, I.; Urreta, J.; Frias, M.; García, R. 2009. Freeze-thaw resistance of blended cements containing calcined paper sludge, Construction and Building Materials 23(8): 2862-2868. 
Venkateshwaran, N.; Perumal, A. E.; Arunsundaranayagam, D. 2013. Fiber surface treatment and its effect on mechanical and visco-elastic behaviour of banana/epoxy composite, Materials and Design 47: 151-159.

Wada, H.; Fukuda, H. 2009. All-water-blown integral skin foam prepared by novel polypropylene glycols, Journal of Cellular Plastics, 45(4): 293-302.

Wah, C. A.; Choong, L. Y.; Neon, G. S. 2000. Effects of titanate coupling agent on rheological behaviour, dispersion characteristics and mechanical properties of talc filled polypropylene, European Polymer Journal 36: 789-801.

Wallington, T. J.; Sulbaek Andersen, M. P.; Nielsen, O. J. 2015. Atmospheric chemistry of short-chain haloolefins: photochemical ozone creation potentials (POCPs), global warming potentials (GWPs), and ozone depletion potentials (ODPs), Chemosphere, 129: 135-141.

Wang, S.; Qian, L.; Xin, F. 2016. The synergistic flame-retardant behaviors of pentaerythritol phosphate and expandable graphite in rigid polyurethane foams, Polymer Composites 0(0): 00-00. [Žiūrèta 2017-08-21].

Prieiga per internetą: http://dx.doi.org/10.1002/pc.23939

Wik, V. M.; Aranguren, M. I.; Mosiewicki, M. A. 2011. Castor oil-based polyurethanes containing cellulose nanocrystals, Polymer Engineering and Science 51(7): 1389-1396.

Wimalasiri, Y.; Zou, L. 2013. Carbon nanotube/graphene composite for enhanced capacitive deionization performance, Carbon 59: 464-471.

Wong, H. S.; Barakat, R.; Alhiladi, A.; Saleh, M.; Cheeseman, C. R. 2015. Hydrophobic concrete using waste paper sludge ash, Cement and Concrete Research 70: 9-20.

World Meteorological Organization (WMO). 2011. Scientific assessment of ozone depletion: 2010, global ozone, research and monitoring project: Report 52, World Meteorological Organization, Geneva, Switzerland. 200 p.

Xi, W.; Qian, L.; Chen, Y.; Wang, J.; liu, X. 2015. Addition flame-retardant behaviors of expandable graphite and [bis(2-hydroxyethyl)amino]-methyl-phosphonic acid dimethyl ester in rigid polyurethane foams, Polymer Degradation and Stability 122: 36-43.

Xiaobin, L.; Hongbin, C.; Yi, Z. 2008. Properties of water blown rigid polyurethane foams with different functionality, Journal of Wuhan University of Technology-Mater. Sci. Ed. 23(1): 125-129.

Xie, H.; Yang, W.; Yuen, A. C. Y.; Xie, C.; Xie, J.; Lu, H. 2017. Study on flame retarded flexible polyurethane foam/alumina aerogel composites with improved fire safety, Chemical Engineering Journal 311: 310-317.

Xu, W. Z.; Liu, L.; Wang, S. Q.; Hu, Y. 2015. Synergistic effect of expandable graphite and aluminium hypophosphite on flame-retardant properties of rigid polyurethane foam, Journal of Applied Polymer Science 132(47): 42-48.

Yan, D.; Xu, L.; Chen, C.; Tang, J.; Ji, X.; Li, Z. 2012. Enhanced mechanical and thermal properties of rigid poyurethane foam composites containing graphene nanosheets and carbon nanotubes, Polymer International 61(7): 1107-1114. 
Yan, S.; Crentsil, K. S.; Shapiro, G. 2012. Properties of cement mortar incorporating deinking waste-water from waste paper recycling, Construction and Building Materials 29: 51-55.

Yang, S. R.; Kwon, O. J.; Kim, D. H.; Park, J. S. 2007. Characterization of the polyurethane foam using alginic acid as a polyol, Fibers and Polymers 8(3): 257-262.

Yang, S.; LV, G.; Liu, Y.; Wang, Q. 2013. Synergism of polysiloxane and zinc borate flame retardant polycarbonate, Polymer Degradation and Stability 98: 2795-2800.

Zain, N. M.; Ahmad, S. H.; Ahad, N. A.; Ali, E. S. 2014. Influence of isocyanate structures on mechanical performance of aluminum bonded with green polyurethane adhesive, $A d$ vanced Materials Research 879: 119-127.

Zhang, L.; Yilmaz, E. D.; Schjødt - Thomsen, J.; Rauhe, J. C.; Pyrz, Ryszard. 2011. MWNT reinforced polyurethane foam: processing, characterization and modelling of mechanical properties, Composites Science and Technology 71(6): 877-884.

Zhang, L.; Zhang, M.; Hu, L.; Zhou, Y. 2014. Synthesis of rigid polyurethane foams with castor oil-based flame retardant polyols, Industrial Crops and Products 52: 380-388.

Zhang, L.; Zhang, M.; Zhou, Y.; Hu, L. 2013. The study of mechanical behavior and flame retardancy of castor oil phosphate-based rigid polyurethane foam composites containing expanded graphite and triethyl phosphate, Polymer Degradation and Stability 98: 2784-2794.

Zhang, X. D.; Macosko, C. W.; Davis, H. T.; Nikolov, A. D.; Wasan, D. T. 1999. Role of silicone surfactant in flexible polyurethane foam, Journal of Colloid and Interface Science 215: 270-279.

Zhao, C.; Yan, Y.; Hu, Z.; Li, L.; Fan, X. 2015. Preparation and characterization of granular silica aerogel/polyisocyanurate rigid foam composites, Construction and Building Materials 93: 309-316.

Zieleniewska, M.; Leszczyński, M. K.; Kurańska, M.; Prociak, A.; Szczepkowsi, L.; Krzyżowska, M.; Ryszkowska, J. 2015. Preparation and characterisation of rigid polyurethane foams using a repeseed oil-based polyol, Industrial Crops and Products 74: 887-897.

Zieleniewska, M.; Leszczyński, M. K.; Szczepkowski, L.; Bryśkiewicz, A.; Krzyżowska, M.; Bień, K.; Ryszkowska, J. 2016. Development and applicational evaluation of the rigid polyurethane foam composites with egg shell waste, Polymer Degradation and Stability 132: 78-86.

Zlatanić, A.; Javni, I.; Ionescu, M.; Bilić, N.; Petrović, Z. S. 2015. Polyurethane molded foams with high content of hyperbranched polyols from soybean oil, Journal of Cellular Plastics 51(3): 289-306.

Zlatanić, A.; Lava, C.; Zhang, W.; Petrović, Z. S. 2004. Effect of structure on properties of polyols and polyurethanes based on different vegetable oils, Journal of Polymer Science: Part B: Polymer Physics 42: 809-819. 
Zule, J.; Černec, F.; Likon, M. 2007. Chemical properties and biodegrability of waste paper mill sluges to be used for landfill covering, Waste Maagement and Research 25(6): 538-546. 



\section{Autorès mokslinių publikacijų disertacijos tema sąrašas}

\section{Straipsniai recenzuojamuose mokslo žurnaluose}

Kairytè, A.; Vejelis, S. 2015. Evaluation of forming mixture composition impact on properties of water blown rigid polyurethane (PUR) foam from rapeseed oil polyol, Industrial Crops and Products 66: 210-215 (Clarivate Analytics Web of Science, $\mathrm{IF}_{2015}=3,449$ ).

Kairytė, A.; Vaitkus, S.; Balčiūnas, G. 2016. The impact of chain extender on the properties of polyurethane foam based on rapeseed oil polyol obtained via chemo - enzymatic route, Engineering Structures and Technologies 8(3): 101-107.

Kairytè, A.; Vaitkus, S.; Vejjelis, S. 2017. Titanate - based surface modification of paper waste particles and its impact on rigid polyurethane foam properties, Key Engineering 721: 58-62.

Kairytė, A.; Ivdre, A.; Vaitkus, S. 2017. Dimensionally stable water - blown polyurethane foam extended with bio - based propylene glycol and modified with paper waste sludge, Engineering Stuctures and Technologies 9(2): 93-103.

Kairytė, A. 2017. Review on paper waste sludge and feasibility of it and its components to be recycled in polymer - based composites, International Journal of Engineering and Applied Sciences 4(1): 10-13. 



\section{Summary in English}

\section{Introduction}

\section{The formulation of the problem}

Polyols for polyurethane foam must conform to the specific requirements - its functionality should be $>3$, molecular weight $-<1200 \mathrm{~g} / \mathrm{mol}$ and hydroxyl value in the range of $350-600 \mathrm{mg} \mathrm{KOH} / \mathrm{g}$. Conforming the mentioned requirements, polyols from renewable resources become cheap and ecological alternative to traditional petroleum based polyols. Regardless of the polyol used in the production, polyurethane foam is characterised by low thermal stability, high flammability and sensitivity to higher temperatures. For the improvement of these properties, organic and inorganic fillers may be incorporated, and they are one of the alternatives for the production of biomaterials.

According to the ozone depletion (ODP) and global warming (GWP) potentials, the same legislations determine the usage terms and replacement possibilities of other raw materials such as blowing agents by non-hazardous alternatives. Based on ODP, GWP, price, easiness of use and storage, water is one of the most promising alternatives for the production of polyurethane foam, however, the final product made of polyols which do not conform the aforesaid requirements are characterised by excessive initial shrinkage at $23{ }^{\circ} \mathrm{C}$ temperature and $50 \%$ relative humidity and improper dimensional stability at $70{ }^{\circ} \mathrm{C}$ temperature and $90 \%$ relative humidity conditions what can be explained by rapid diffusion of $\mathrm{CO}_{2}$ out of the foam. This is especially relevant for thermal insulation of industrial and residential buildings. In this case, dimensional changes could determine the occurence 
of cracks between insulated and insulating surfaces, thus leading to nonconformity of its purpose as thermal insulating material. In such structures, deformations caused would destroy the finish layer of the building, and the moisture could easily penetrate.

\section{The relevance of the thesis}

The main strategy of European Commissions to achieve one of the targeted sustainable development's aims to reduce the emission of greenhouse gases by $20 \%$ up to 2020 and by $80 \%$ up to 2050 . Therefore, increasing requirements for energy performance which include not only the improvement of thermal insulating properties of building materials but input for the materials production and installation as well, increase the demand for not only energetically but ecologically efficient materials in building materials sector. The use of renewable resources and especially industrial waste is an excellent alternative for the production of thermal insulating materials. One of the 17 aims for sustainable development is reduction and reuse of waste; therefore, the intensive efforts are put to figure out how paper waste sludge can be used in the same or other industrial areas in order to obtain products which could be characterised by the same or even better properties.

From the ecological point of view, the application of polyols from renewable resources, water and organic as well as inorganic waste system for the production of polyurethane foam is currently relevant. In order to use such products in building industry, it is important to conduct scientific researches which allow determination of possibilities to obtain dimensionally stable products which conform to the ecology and energy-efficiency principles.

\section{The object of the research}

Polyurethane foam synthesized from rapeseed oil based polyols and modified with paper production waste sludge particles.

\section{The aim of the thesis}

To develop and investigate stable polyurethane foam synthesized from rapeseed oil based polyols and modified with paper production waste sludge particles.

\section{The objectives of the thesis}

In order to achieve the aim of the thesis, it is necessary to solve the following objectives:

1. To investigate the impact of water as a blowing agent on initial shrinkage and dimensional stability at higher temperature and humidity conditions as well as density of polyurethane foam.

2. To investigate the impact of propylene glycol from rapeseed glycerine and rapeseed glycerine on physical and mechanical properties of water-blown polyurethane foam. 
3. To investigate the impact of titanate coupled paper production waste sludge particles on reaction kinetics, physical, mechanical and chemical properties of propylene glycol extended polyurethane foams.

4. To present recommendations for amounts limits of propylene glycol from rapeseed glycerine as well as thermally and chemically treated paper production waste sludge particles based on the production method, rheology of mixtures and physical properties of the final products.

\section{Research methodology}

For the characterisation of forming mixtures, dynamic viscosity, temperature, characteristic foaming times determination methods are used.

For the investigation of paper production waste sludge particles, standard bulk density for loose-fill materials, surface area, thermal conductivity, particle size and moisture content determination methods are implemented.

$\mathrm{X}$-ray diffraction and X-ray fluorescence, thermogravimetric and differential thermal analyses are used for quantitative and qualitative characterisation of the materials.

For the investigation of polyurethane foam extended with propylene glycol and modified with paper production waste sludge particles, methodologies for determination of apparent density, compressive strength perpendicularly to the foaming direction, thermal conductivity, initial shrinkage, dimensional stability, water vapour permeability, longterm water absorption and fire resistance are implemented.

Scanning electron microscopy, closed cell content determination and hard as well as soft segments calculation methods are used for structure tests and determination of structural parameters. For the processing of the results and evaluation of reliability, mathematical and statistical methods are applied.

\section{The scientific novelty of the thesis}

During preparation of the thesis, the following novel results for science of material engineering are obtained:

1. The dependence of apparent density on water amount allowing prediction of average values of apparent density of the future products without preliminary initial tests is obtained.

2. Propylene glycol from rapeseed glycerine enables the adjustment of structure and properties of the final products thus maintaining ecology balance between employed raw materials.

3. The determined amounts of propylene glycol allow utilization from 1.5 to 2 times greater amount of paper production waste sludge particles and obtainment of dimensionally stable modified polyurethane foams thus reducing exposure time after production up to 24 hours and, in conjunction with paper production waste sludge particles, increasing the strength and fire resistance of the final products. 


\section{The practical value of the research findings}

Research results may be used for dimensional stabilization (after production and, based on application area, at higher temperature and humidity conditions) of traditional as well as modified polyurethane foams from low functionality vegetable oil based polyols. Developed modified polyurethane foams can be applied in structures of building envelopes where continuous and direct water impact does not occur.

\section{The defended statements}

1. Propylene glycol enables the control of initial shrinkage of rigid polyurethane foams by ensuring formation of fully or partially open cell structure.

2. Paper production waste sludge particles and their agglomerates act as a barrier for flame spread in rigid polyurethane foam under open flame and ensure lower heat release rate and emission of toxic gases during combustion.

\section{The approval of the research findings}

5 scientific articles are published on the topic of the thesis: one - in scientific journal included in Clarivate Analytics Web of Science database (Kairytè, Vèjelis 2015); three - in journals included in international databases (Kairyte et al. 2016, Kairytè et al. 2017a, Kairytė 2017), one - in peer reviewed international conference material (Kairytè et al. 2017b).

The results of conducted research are presented in 6 national and international scientific conferences:

- "The $9^{\text {th }}$ World Congress on Materials Science and Engineering", 2017, Rome, Italy;

- $20^{\text {th }}$ Young Scientists Conference "Science - Future of Lithuania“, 2017, Vilnius, Lithuania;

- "The $25^{\text {th }}$ International Baltic Conference of Engineering Materials and Tribology”, 2016, Riga, Latvia;

- $19^{\text {th }}$ Young Scientists Conference "Science - Future of Lithuania“, 2016, Vilnius, Lithuania;

- $5^{\text {th }}$ Young Scientists Conference "Interdisciplinary Research of Physical and Technological Sciences", 2015, Vilnius, Lithuania;

- $17^{\text {th }}$ Young Scientists Conference "Science - Future of Lithuania“, 2014, Vilnius, Lithuania.

\section{The structure of the thesis}

The thesis consists of introduction, three chapters, general conclusions, lists of references and author's publications.

The extent of the thesis (excluding annexes) is 131 pages, 21 numbered equations, 35 figures, 21 tables and 197 references. 


\section{Research analysis of raw materials and their impact on polyurethane foam properties}

The use of renewable resources for the synthesis of chemical materials reduces the negative impact on the environment, e. g. consumption of limited resources and emission of greenhouse gases. These resources open up opportunities to partial or even full replacement of petroleum based polymers what can compete and surpass traditional materials in respect with price, quality and environmental impact.

Literature review shows that traditional polyol for polyurethane foam production may be replaced by $70 \%$ of biopolyol from vegetable oils. However, low functional groups values determine high changes in linear dimensions for water-blown systems.

In order to assure and improve physical-mechanical properties of polyurethane foam from biopolyol, it is appropriate to use up to $20 \%$ of multifunctional petroleum based organic compounds - chain extenders or cross linking agents, however, there is no information on ecological compounds for this purpose.

Pollution prevention in paper production industry is the main worldwide aspiration. One of the main aims of European Commissions and Directives - to transform European Union countries into "recycling community" which is capable to reduce the accumulation of waste and use them in different processes.

Paper production waste sludge (PPWS) is the main and the greatest by-product in paper production, and its elimination as well as destruction is a primary environmental problem. It is determined that PPWS is porous but researches on how these waste could be used in the production of thermal insulating materials have not been yet conducted.

It is well known that higly filler polymer systems are characterised by high viscosyti, therefore, in order to improve flowability of the particle filler polymer mixture, it is appropriate to use from $1 \mathrm{wt} . \%$ to $3 \mathrm{wt} . \%$ of titanate, silane or zirconate coupling agents.

\section{Materials and research methodologies of polyurethane foam}

Polyester rapeseed oil based polyol (PLLC IMD technologies, Lithuania). Hydroxyl value of polyol is $323 \mathrm{mg} \mathrm{KOH} / \mathrm{g}$, functionality -2.7 and moisture content $-0.25 \%$. Chain extender - propylene glycol from rapeseed glycerine (RPG) (ADM Industrials, Germany) with hydroxyl value of $1474 \mathrm{mg} \mathrm{KOH} / \mathrm{g}$, functionality -2 and moisture content $-0.13 \%$. Distilled water is used as a blowing agent. 4,4'-diphenylmethane diisocyanate Lupranat M20S (BASF, Germany) is used as a hardener. Paper production waste sludge particles (JSC Grigeo Grigiškès, Lithuania) are used as a filler, qualitative and quantitative composition is: 5.8-6.0 wt. \% of $\mathrm{SiO}_{2}, 4.6-4.8$ wt. $\%$ of $\mathrm{Al}_{2} \mathrm{O}_{3}, 48.5-49.5$ wt. \% of $\mathrm{CaO}$, $0.4-0.5$ wt. $\%$ of $\mathrm{MgO}, 0.5-0.6$ wt. $\%$ of $\mathrm{Fe}_{2} \mathrm{O}_{3}, 0.03-0.04$ wt. $\%$ of $\mathrm{Na}_{2} \mathrm{O}, 0.14-0.15$ wt. \% of $\mathrm{K}_{2} \mathrm{O}, 0.17-0.20$ wt. \% of $\mathrm{SO}_{3}, 0.05-0.06$ wt. \% of $\mathrm{P}_{2} \mathrm{O}_{5}, 21.1-24.3$ wt. \% of organic matter, $13.9-18.7 \mathrm{wt}$. $\%$ of other. The size of particles is in the range of $0.4-630 \mu \mathrm{m}$. $1 \mathrm{wt} . \%$ of titanate coupling agent TCA - K44 (Capatue Chemicals, China) is implemented to reduce 
the viscosity of forming mixture. For blowing and gelling reactions, 1.2 parts by weight (pbw) of N,N-dimethylethanolamine Lupragen N101 (BASF, Germany) and 1.8 pbw of 1,2-dimethylimidazole Lupragen DMI (BASF, Germany) catalysts are chosen. 2.0 pbw of surfactant Tegostab B 1048 (Evonik, Germany) is used.

PPWS has been dried for $24 \mathrm{~h}$ at $70 \pm 5{ }^{\circ} \mathrm{C}$ temperature. Dried stone shaped PPWS is crushed, milled and sieved through $0.63 \mathrm{~mm}$ size sieve. They have been initially dispersed in $100 \mathrm{ml}$ of isopropyl alcohol and thoroughly mixed. The obtained solution is poured into a ceramic dish with $100 \mathrm{~g}$ of well agitated PWS particles, mixed $30 \mathrm{~min}$ and dried in ventilated oven at $(100 \pm 5)^{\circ} \mathrm{C}$ for 48 hours.

Amounts of raw materials for the production of propylene glycol extended and PPWS particles modified polyurethane foams are presented in Table S2.1.

Properties of modified polyurethane foam are determined according to the following standards: thermal conductivity - EN 12667 using apparatus FOX 304, compressive strength - EN 826 with testing machine H10KS Housfield. Moisture properties: long-term water absorption by total immersion-EN 12087 method 2A, water vapour diffusion - EN 12086. The assemblies with specimens for water vapour diffusion determination is exposed to temperature of $23^{\circ} \mathrm{C}$ and relative humidity of $50 \%$. The relative humidity in the sealed assemblies is $95 \%$, and the humidity is obtained using potassium nitrate solution.

Table S2.1. Composition of propylene glycol extended and paper production waste sludge particles modified polyurethane foams

\begin{tabular}{|l|c|c|c|c|c|}
\hline \multicolumn{7}{|c|}{ Material } & \multicolumn{7}{c|}{ Amount, pbw } \\
\hline \multirow{2}{*}{ Polyol } & $90 ; 85 ;$ & $90 ; 85 ;$ & $90 ; 85 ;$ & $90 ; 85 ;$ & $90 ; 85 ;$ \\
& 80 & 80 & 80 & 80 & 80 \\
\hline \multirow{2}{*}{ RPG } & $10 ; 15 ;$ & $10 ; 15 ;$ & $10 ; 15 ;$ & $10 ; 15 ;$ & $10 ; 15 ;$ \\
& 20 & 20 & 20 & 20 & 20 \\
\hline Distilled water & 3.0 & 3.0 & 3.0 & 3.0 & 3.0 \\
\hline Lupragen N101 & 1.2 & 1.2 & 1.2 & 1.2 & 1.2 \\
\hline Lupragen DMI & 1.8 & 1.8 & 1.8 & 1.8 & 1.8 \\
\hline Tegostab B 1048 & 2.0 & 2.0 & 2.0 & 2.0 & 2.0 \\
\hline PPWS, wt.\% & 0 & 5 & 10 & 15 & 20 \\
\hline \multicolumn{7}{|c|}{ Component B } \\
\hline Isocyanate & \multicolumn{7}{|l|}{ Index 125 } \\
\hline \multirow{2}{*}{ Recalculated amount of water ${ }^{\mathrm{a}}$} & $2.76 ;$ & $2.54 ;$ & $2.32 ;$ & $2.10 ;$ & $1.88 ;$ \\
& $2.77 ;$ & $2.53 ;$ & $2.30 ;$ & $2.07 ;$ & $1.84 ;$ \\
\hline
\end{tabular}

a Overall moisture contents in polyol, PPWS and RPG are recalculated for distilled water required in order to foam specimens.

Initial shrinkage is evaluated after $0.5 \mathrm{~h}$ and 1 day after production, dimensional stability is determined according to LST EN 1604 at $70 \pm 2{ }^{\circ} \mathrm{C}$ temperature and $90 \pm 5 \%$ humidity conditions after $48 \mathrm{~h}$. Reaction to fire test is conducted based on ISO 5660-1 requirements using FTT Dual cone calorimeter. Structure research is performed with JEOL JSM $-7600 \mathrm{~F}$ electron microscope, closed cell content is calculated according to EN ISO 4590 method 2. 


\section{Research of structure and physical properties of propylene glycol extended and paper production waste sludge particles modified polyurethane foams}

Apparent density is one of the main and the most important parameters determining stability properties in respect with strength and durability of the final products. Whereas the density of fillers used for thermal insulating materials is higher than the polymer matrix, it is relevant to evaluate the apparent density of the final polyurethane foams modified with PPWS particles from $5 \mathrm{wt}$. \% to $20 \mathrm{wt}$ \%. The dependence of its numerical values on the amount of PPWS particles is presented in Fig. S3.1.

The obtained results show that apparent density of 10 pbw, 15 pbw and 20 pbw of RPG extended rigid polyurethane foams depends on the amount of PPWS particles. In order to quantitatively evaluate these factors, mathematical and statistical analysis is implemented. It shows that average values of apparent density of RPG extended and PPWS particles modified polyurethane foams may be approximated by the regression equation (S3.1). The average square deviation of this equation is $S_{\bar{\rho}_{R P G / P P W S}}=2.93 \mathrm{~kg} / \mathrm{m}^{3}$ and correlation square ratio $-\eta_{\bar{\rho}_{R P G / P P W S}}^{2}=0.843$.

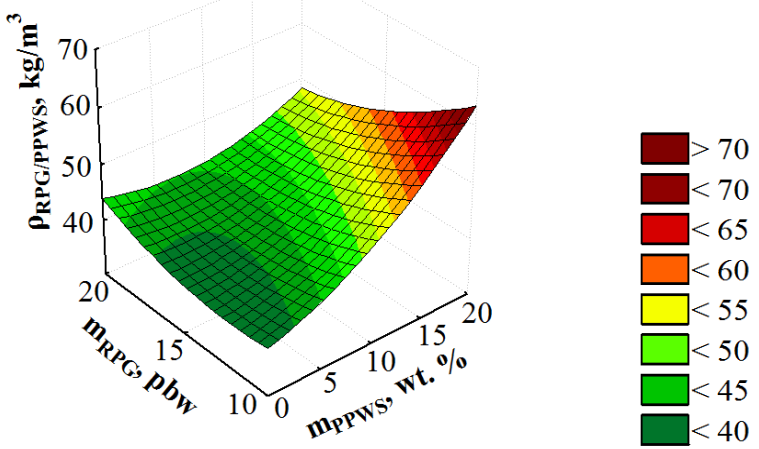

Fig. S3.1. Graphical interpretation of apparent density dependence of polyurethane foam on the amounts of propylene glycol and paper production waste sludge particles

The suggested non-linear regression model (S3.1) allows explanation of apparent density variation which is by $84.3 \%$ determined by the change in the amounts of PPWS particles (from 0 wt. $\%$ to $20 \mathrm{wt}$ \%) and RPG (from $10 \mathrm{pbw}$ to $20 \mathrm{pbw}$ ). The presented regression equation is only valid at the apparent density range of $33.9-70.9 \mathrm{~kg} / \mathrm{m}^{3}$.

$$
\begin{gathered}
\bar{\rho}_{R P G / P P W S}=53.0+1.52 \cdot m_{P P W S}-2.44 \cdot m_{R P G}+0.0376 \cdot m_{P P W S}^{2}- \\
0.103 \cdot m_{P P W S} \cdot m_{R P G}+0.0996 \cdot m_{R P G}^{2},
\end{gathered}
$$


where $\bar{\rho}_{R P G / P P W S}$-the average apparent density value of RPG extended and PPWS particles modified polyurethane foams, $\mathrm{kg} / \mathrm{m}^{3} ; m_{P P W S}$ the amount of PPWS particles, wt. \%; $m_{R P G}$ - the amount of RPG, pbw.

It can be observed that the addition of PPWS particles from 5 wt. \% to 20 wt. \% increases the apparent density of the final products. Whereas the bulk density of PPWS particles is $480 \mathrm{~kg} / \mathrm{m}^{3}$, the apparent density of polyurethane foams modified with $5 \mathrm{wt}$. \% of PPWS particles averagely increases by $\sim 11 \%, \sim 0.2 \%$ and $\sim 2 \%$, modified with $10 \mathrm{wt}$. $\%$ of PPWS particles - by $\sim 18 \%, \sim 3 \%$ and $\sim 4 \%$, modified with 15 wt. $\%$ of PPWS particles - by $\sim 44 \%, \sim 8 \%$ and $\sim 9 \%$, modified with 20 wt. $\%$ of PPWS particles - by $\sim 78 \%$, $\sim 15 \%$ and $\sim 21 \%$, respectively, at 10 pbw, 15 pbw and 20 pbw of RPG.

As literature review shows, the type of filler, its modification, particle size, shape as well as interaction between filler and matrix has a great impact on composite systems, therefore, it is necessary to evaluate the influence of these factors on the main mechanical characteristic - compressive strength of RPG extended and PPWS particles modified polyurethane foams. Fig. S3.2 shows that increasing the amount of PPWS particles from 5 wt. \% to $20 \mathrm{wt}$. \% in all RPG extended systems increases the compressive strength of polyurethane foams.

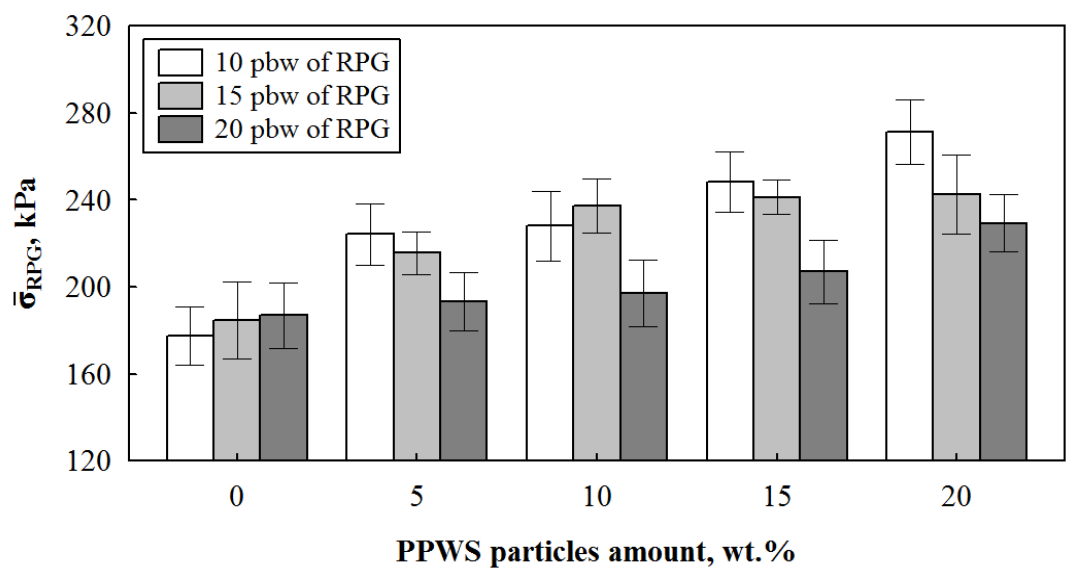

Fig. S3.2. The impact of propylene glycol and paper production waste sludge particles on compressive strength of polyurethane foam

It means that PPWS particles improve the rigidity of the material. The increase in compressive strength is determined by enhanced interfacial bond between PPWS particles and polymer matrix resulting into more effective stress transfer from matrix to the filler during compression. Compared to control polyurethane foam, the compressive strength of PPWS particles modified polyurethane foam at maximum amount of PPWS particles averagely increases by $52.7 \%, \sim 31.3 \%$ and $\sim 22.7 \%$, respectively, at $10 \mathrm{pbw}, 15 \mathrm{pbw}$ and $20 \mathrm{pbw}$ of RPG. It is as well can be seen that increasing amount of RPG from $10 \mathrm{pbw}$ to $20 \mathrm{pbw}$, reduces the strength growth tendency. It can be explained by increasing amount of difunctional RPG in polyol mixture which determines more brittle but stronger structure 
of polyurethane foams what reduces interfacial adhesion between particles and polymer matrix. Fig. S3.3 presents scanning electron microscopy images of 10 pbw (Fig. S3.3 a and b), 15 pbw (Fig. S3.3 c and d) and 20 pbw (Fig. S3.3 e and f) of RPG extended polyurethane foams without and with $20 \mathrm{wt}$. \% of PPWS particles. Compared to control foam, closed cell contents in 10 pbw of RPG extended polyurethane foams are averagely greater by $14.7 \%, 16.5 \%, 19.9 \%$ and $27.9 \%$, in 15 pbw of RPG extended foams - by $45.7 \%$, $47.6 \%, 49.1 \%$ and $51.3 \%$, in 20 pbw of RPG extended foam - by $58.7 \%, 60.0 \%, 60.6 \%$ and $62.0 \%$, respectively, at varying amounts of PPWS particles from $5 \mathrm{wt}$. $\%$ to $20 \mathrm{wt} . \%$.

Increasing closed cell content reduces the average cell size. It means that higher quantity of cells forms in the same volume. Whereas the most active heteronucleis are in the range of $0.1-1 \mu \mathrm{m}$ (Mulin 2001) and the size of PPWS particles is $>0.04 \mu \mathrm{m}$, the respective part of PPWS particles acts as nucleation centres hereby reducing the cell size in polyurethane foam structure.

The images and Table S3.2 show that compared to control foams, PPWS particles modified foams are characterised by partially or fully closed cell system and reducing cell size.

Table S3.2. Structural parameters of propylene glycol and paper production waste sludge particles modified polyurethane foam

\begin{tabular}{|l|c|c|c|c|c|c|}
\hline \multirow{3}{*}{ Parameter } & \multirow{2}{*}{$\begin{array}{c}\text { RPG a- } \\
\text { mount, } \\
\text { pbw }\end{array}$} & \multicolumn{5}{|c|}{ PPWS particles amount, wt. \% } \\
\cline { 3 - 7 } & \multirow{2}{*}{10} & 64.4 & 5 & 10 & 15 & 20 \\
\hline \multirow{3}{*}{ Closed cell } & & \pm 4.7 & \pm 9.1 & 80.9 & 84.3 & 92.3 \\
content, & \multirow{2}{*}{15} & 31.3 & 77.6 & 78.9 & 80.4 & 82.6 \\
vol. \% & & \pm 2.4 & \pm 4.2 & \pm 3.7 & \pm 2.4 & \pm 4.0 \\
\cline { 2 - 7 } & \multirow{2}{*}{20} & 18.5 & 77.2 & 78.5 & 79.1 & 80.5 \\
& & \pm 2.4 & \pm 2.8 & \pm 2.3 & \pm 4.2 & \pm 3.8 \\
\hline \multirow{4}{*}{ Cell size, } & \multirow{2}{*}{10} & 0.338 & 0.301 & 0.298 & 0.284 & 0.275 \\
mm & \multirow{2}{*}{15} & \pm 0.052 & \pm 0.024 & \pm 0.052 & \pm 0.069 & \pm 0.037 \\
\cline { 2 - 7 } & & \pm .458 & 0.298 & 0.166 & 0.291 & 0.284 \\
& \multirow{2}{*}{20} & 0.469 & 0.324 & 0.312 & 0.295 & 0.285 \\
& & \pm 0.067 & \pm 0.047 & \pm 0.063 & \pm 0.047 & \pm 0.026 \\
\hline
\end{tabular}

Even 5 wt. \% of PPWS particles averagely reduce cell size by $10.9 \%, 34.9 \%$ and $30.9 \%$, respectively, at $10 \mathrm{pbw}, 15 \mathrm{pbw}$ and $20 \mathrm{pbw}$ of RPG. In non-modified polyurethane foams, the dominant nucleation process and mechanism is homogeneous and, compared to heterogeneous, its activation energy is greater. It is explained by increasing amount of isocyanate which is determined by increasing hydroxyl value of polyol and RPG mixture. Higher amount of this material leads to more effective blowing efficiency of the foam thus changing its structure by extending the cells.

The greatest part of thermal conductivity value, i. e. $\sim 65-80 \%$, consists of thermal conductivity through gases or their mixture (Jarfelt, Ramnäs 2006). 

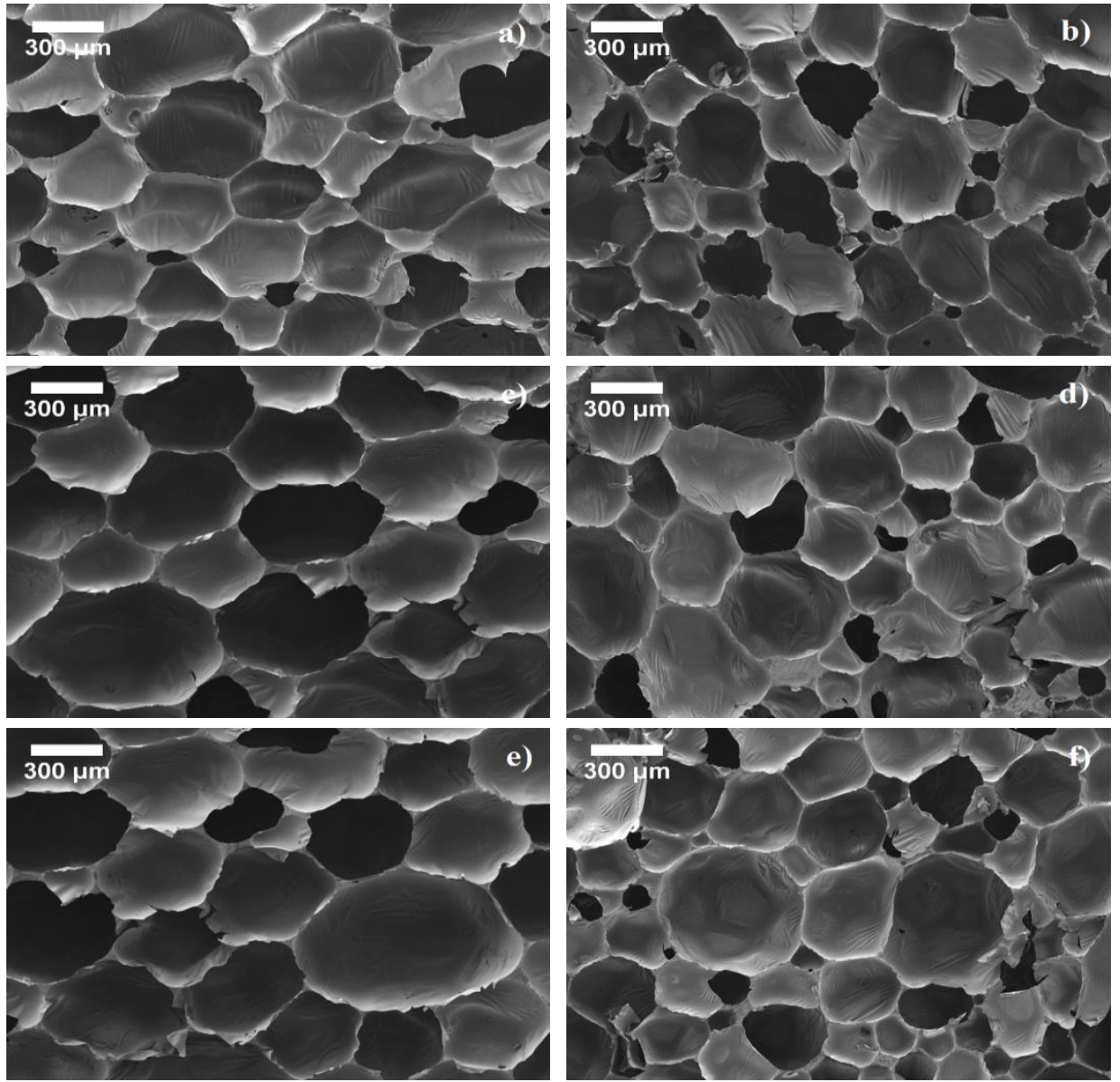

Fig. S3.3. Microstructure of polyurethane foam modified with: a) 10 parts by weight of propylene glycol; b) 10 parts by weight of propylene glycol and $20 \mathrm{wt}$. \% of paper production waste sludge; c) 15 parts by weight of propylene glycol; d) 15 parts by weight of propylene glycol and $20 \mathrm{wt}$ \% of paper production waste sludge; e) 20 parts by weight of propylene glycol; f) 20 parts by weight of propylene glycol and $20 \mathrm{wt}$. \% of paper production waste sludge (magnification $\times 50$ )

This, the main property of thermal insulating materials, as well dependant on the type of gases used for the production and their diffusion rate out of the product. $\mathrm{CO}_{2}$ gases which are characterised by greater diffusion rate compared to tradition blowing agents emit during the reaction between isocyanate, water and moisture existent in raw materials. These gases existing in cells are shortly replaced by air, therefore, it is of great importance to evaluate the change of this parameter over the time.

Research results (Annex C) show that polyurethane foams modified with 5 wt. $\%$ of PPWS particles have averagely by $\sim 19.3 \%$ (10 pbw of RPG), 24.8\% (15 pbw of RPG) and $24.6 \%$ (20 pbw of RPG) lower thermal conductivity after 1 day after production compared to control foams. It can be attributed to the increased percentage closed cell 
content which determines the diffusion rate of gases out of material's structure, as well as reduced average cell size (Table S3.2) from which one of the thermal conductivity components - radiation is dependant. Whereas closed cell content is considerably lower in all RPG extended control foams, diffusion of $\mathrm{CO}_{2}$ gases is faster what determines higher thermal conductivity values after 1 day after production of RPG extended and PPWS particles modified polyurethane foams.

Further addition of PPWS particles does not have any impact on thermal conductivity values, however, it can be observed that increasing amount of RPG from 10 pbw to 20 pbw increases the average values of this parameter after 1 day after production but only slightly, i. e. up to $2 \%$ for polyurethane foams modified from 5 wt. $\%$ to $20 \mathrm{wt}$. $\%$ of PPWS particles.

Even though the modification of polyurethane foam with PPWS particles determines lower thermal conductivity after 1 day after production, yet after 14 and 28 days after production, average values of this parameter of all RPG extended and PPWS particles modified polyurethane foams vary within small range, i. e. become similar.

In order to evaluate the impact of PPWS particles, RPG and time on thermal conductivity of polyurethane foams, non-linear regression equation (S3.2) is obtained on the basis of the research results:

$$
\begin{aligned}
\bar{\lambda}_{R P G / P P W S / t}= & 0.029-0.0052 \cdot m_{P P W S}+0.00080 \cdot t+0.000016 \cdot m_{P P W S}^{2}- \\
& 0.00020 \cdot t^{2}+0.0000010 \cdot m_{P P W S} \cdot m_{R P G} \cdot t,
\end{aligned}
$$

where $\bar{\lambda}_{R P G / P P W / t}$ - average value of thermal conductivity of RPG extended and PPWS particles modified polyurethane foams after $t$ days after production, $\mathrm{W} /(\mathrm{m} \cdot \mathrm{K})$; $m_{P P W S}-$ PPWS particles amount, wt. $\% ; t$-exposure time after production of RPG extended and PPWS particles modified polyurethane foams; $m_{R P G}-$ RPG amount, pbw.

Average square deviation of regression equation $\begin{gathered}(\mathrm{S} 3.2) \\ S_{\bar{\lambda}_{R P G / P P W S} / t}\end{gathered}=0.00142 \mathrm{~W} /(\mathrm{m} \cdot \mathrm{K})$ and correlation square ratio $-\eta_{\bar{\lambda}_{R P G / P P W S} / t}^{2}=0.886$. The
suggested non-linear regression model allows explanation of variation in thermal conductivity which is by $88.6 \%$ determined by the change in the amounts of PPWS particles (from $0 \%$ to $20 \%$ ), RPG (from $10 \mathrm{pbw}$ to $20 \mathrm{pbw}$ ) and exposure time (from 1 day to 28 days). The presented regression equation is only valid at thermal conductivity range of $0.0253-0.0359 \mathrm{~W} /(\mathrm{m} \cdot \mathrm{K})$.

For the production of PPWS particles modified polyurethane foams, RPG is chosen, and its impact on the dimensional changes of the products is presented in Fig. S4. The obvious difference between the results of dimensional stability of 10 pbw and from 15 pbw to 20 pbw of RPG extended and PPWS particles modified polyurethane foams can be observed.

The percentage initial shrinkage of $10 \mathrm{pbw}$ of RPG extended foams is increased from $\mathrm{MS}(0 / 0 / 0)$ to $\mathrm{MS}(1.5 / 2.6 / 3.4)$, respectively, at the directions of length, width and thickness, when the system contains maximum amount, i. e. 20 wt. \% of PPWS particles. The reason is the capability of PPWS particles to stimulate the nucleation process, during which, more smaller closed cells are formed. Contrary to the results presented in Fig. S3.4 a, Fig. S3.4 b and Fig. S3.4 c show that under increasing amount of 
low molecular weight RPG from 15 pbw to 20 pbw in high molecular weight polyol, structurally and dimensionally stable foams with the initial shrinkage after 1 day after production equal to $0 \%$ may be obtained even at $20 \mathrm{wt}$. \% of PPWS particles.

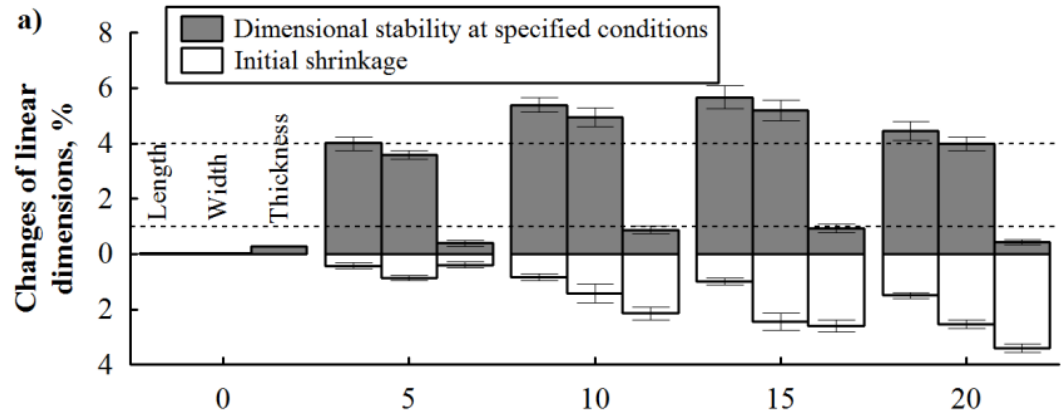

PPWS particles amount, wt.\%

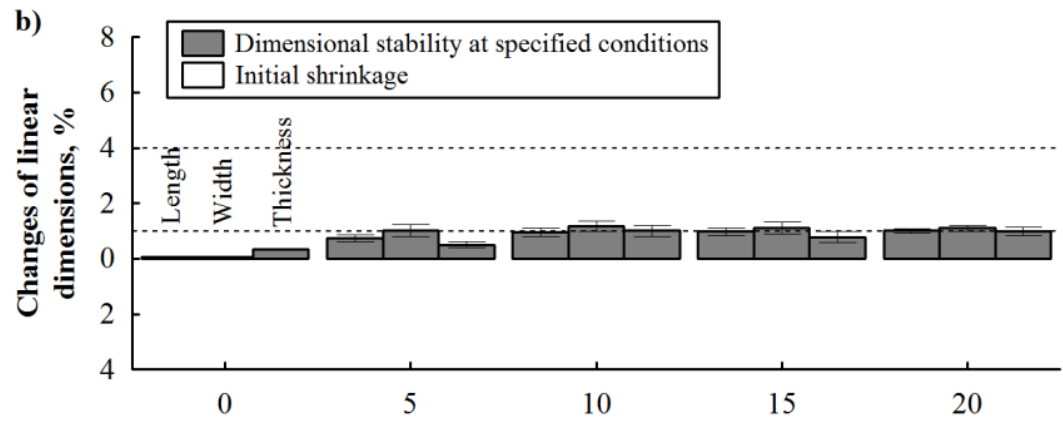

PPWS particles amount, wt.\%

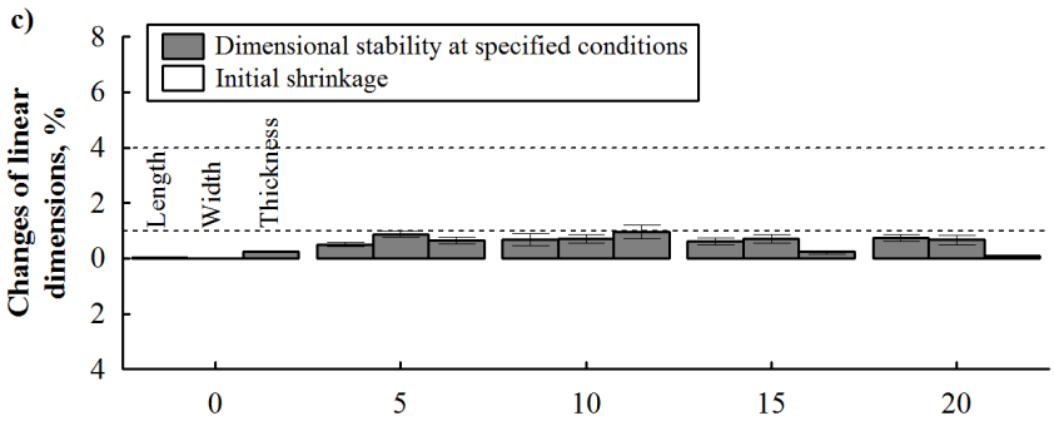

PPWS particles amount, wt.\%

Fig. S3.4. Initial shrinkage and dimensional stability of paper production waste sludge particles modified polyurethane foam when propylene glycol amount in parts by weight is: a) 10; b) 15 and c) 20. (-----) - the strictest requirements for dimensional changes in the directions of length, width and thickness according to EN 13165 requirements 
These changes of 15 pbw and 20 pbw of RPG extended foams conform to the strictest requirements of EN 13165 arising for factory made rigid polyurethane foams, i. e. $\leq 1 \%$ for length and width and $\leq 4 \%$ for thickness.

When thermal insulating materials are used for building envelope structures, water impact may occur (direct or in the shape of vapour) from which intensity, physical and mechanical properties of thermal insulating layer are dependant. The change of these properties determines the application area of thermal insulating layer, therefore, it is important to know the moisture properties of the material used. Table S3.3 presents average values of water vapour diffusion resistance factor and long-term water absorption by total immersion of RPG extended and PPWS particles modified polyurethane foams.

Long-term water absorption reduces and water vapour diffusion resistance factor increases for $10 \mathrm{pbw}$ of RPG extended and from $5 \mathrm{wt}$. \% to $20 \mathrm{wt}$. \% of PPWS particles modified polyurethane foams. It can be explained by an effective coupling of PPWS particles with titanate coupling agent which contributes to sufficient interfacial adhesion between particles and polymer matrix.

However, contrary results may observed for polyurethane foams extended with 15 pbw and 20 pbw of RPG and modified from 5 wt. $\%$ to 20 wt. $\%$ of PPWS particles. It is attributed to insufficient interaction between components what is determined by increasing amount of difunctional RPG which leads to more brittle but stronger structure of the obtained products.

Table S3.3. Results of water vapour permeability and long - term water absorption of propylene glycol extended and paper production waste sludge modified polyurethane foams

\begin{tabular}{|l|c|c|c|c|c|c|}
\hline \multirow{2}{*}{ Parameter } & \multirow{2}{*}{$\begin{array}{c}\text { RPG a- } \\
\text { mount, } \\
\text { pbw }\end{array}$} & \multicolumn{5}{|c|}{ PPWS particles amount, wt. \% } \\
\cline { 3 - 7 } & \multirow{2}{*}{10} & 42.9 & 43.7 & 44.5 & 41.3 & 44.9 \\
& & \pm 3.6 & \pm 2.3 & \pm 2.2 & \pm 2.0 & \pm 3.5 \\
\cline { 2 - 7 } & \multirow{2}{*}{15} & 40.9 & 34.4 & 33.5 & 32.5 & 26.2 \\
Water vapour di- & \pm 3.7 & \pm 3.8 & \pm 1.4 & \pm 2.8 & \pm 1.2 \\
ffusion resistance & & 39.7 & 33.1 & 28.8 & 25.9 & 27.4 \\
factor $\mu$, b. d. & \multirow{2}{*}{20} & \pm 4.3 & \pm 4.6 & \pm 3.0 & \pm 3.4 & \pm 3.8 \\
\cline { 2 - 7 } & \multirow{2}{*}{10} & 5.69 & 5.63 & 5.52 & 5.27 & 5.35 \\
& & \pm 0.25 & \pm 0.37 & \pm 0.37 & \pm 0.051 & \pm 0.39 \\
\cline { 2 - 7 } & \multirow{2}{*}{15} & 6.06 & 7.98 & 8.40 & 8.57 & 10.7 \\
Long-term water & \pm 0.90 & \pm 0.61 & \pm 0.65 & \pm 0.66 & \pm 0.41 \\
\cline { 2 - 7 } tal immersion, & \multirow{2}{*}{20} & 6.03 & 8.57 & 9.86 & 9.67 & 9.79 \\
vol. \% & \pm 0.096 & \pm 0.34 & \pm 0.39 & \pm 0.43 & \pm 0.41 \\
\hline
\end{tabular}

Thermal degradation of polyurethane foam is of great importance in respect with fundamental and technological perspectives. The research of degradation processes allows determination of optimal conditions in design and production stages and obtainment of products characterised by rational performance characteristics. In order to evaluate the behaviour at performance conditions, fire resistance test of RPG extended and PPWS particles modified polyurethane foam is conducted. 
The main and the most important parameter which directly determines the size of flame and its spread rate, mass losses and emission of toxic gases is heat release rate (HRR). For the interpretation of the obtained results, the selected RPG and PPWS particles amounts are based on the greatest impact on polyurethane foams. The dependences of heat release rate on time of control foam and $20 \mathrm{pbw}$ of RPG as well as $10 \mathrm{wt}$. \% and 20 wt. \% of PPWS particles modified foams are presented in Fig. S3.5.

It can be seen that polyurethane foams analysed belong to the group of materials which form thick char layers. It means that the increase in HRR is observed until the char layer is formed, and it considerably inhibits fire spread.

Control polyurethane foam is characterised by sudden char layer formation which reduces pHRR from $408 \mathrm{~kW} / \mathrm{m}^{2}$ to $118 \mathrm{~kW} / \mathrm{m}^{2}$ after $25 \mathrm{~s}$, however, in $20 \mathrm{pbw}$ of RPG extended and by $10 \mathrm{wt} . \%$ and $20 \mathrm{wt}$. \% of PPWS modified polyurethane foams, slow formation of the mentioned layer and combustion of the material are observed which are accompanied with additional insignificant peaks occurring due to formation of microcracks through which oxygen enters. Slow formation of char layer is determined by decomposition of $\mathrm{CaCO}_{3}$ in PPWS particles and emission of $\mathrm{CO}_{2}$ gases.

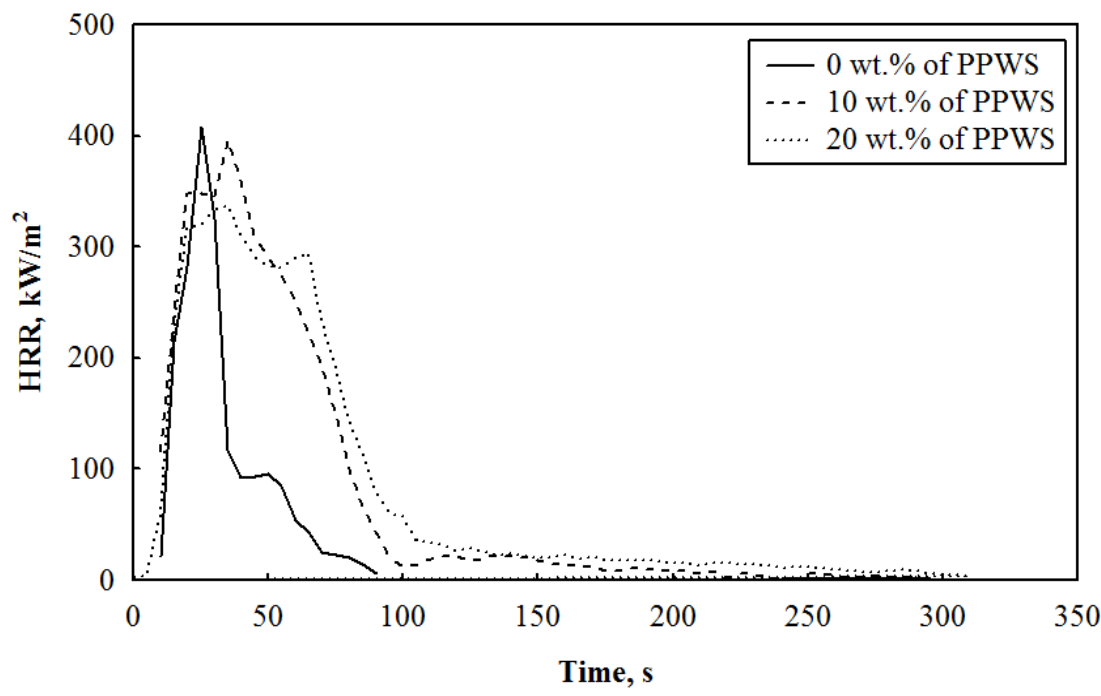

Fig. S3.5. Curves of heat release rate of control polyurethane foam and by $10 \mathrm{wt} \%$ and $20 \mathrm{wt}$ \% of paper production waste sludge particles modified polyurethane foam

When products are used in the places where they can be reached by flame, it is necessary to evaluate the yield of combustion products such as carbon monoxide (CO) and carbon dioxide $\left(\mathrm{CO}_{2}\right)$ (Table S3.4). It can be observed that the yields of such materials reduce under increasing amount of PPWS particles in polyurethane foams. It means that PPWS particles do not increase $\mathrm{CO}$ and $\mathrm{CO}_{2}$ yields in smoke and gas mixtures during combustion. 
Table S3.4. Average values of fire resistance tests of propylene glycol extended and paper production waste sludge particles modified polyurethane foams

\begin{tabular}{|l|c|c|c|}
\hline \multirow{2}{*}{ Parameter } & \multicolumn{3}{|c|}{ PPWS particles amount, wt. \% } \\
\cline { 2 - 4 } & 0 & 10 & 20 \\
\hline pHRR $_{\text {av. }}, \mathrm{kW} / \mathrm{m}^{2}$ & $372 \pm 42$ & $373 \pm 49$ & $353 \pm 47$ \\
\hline THR $_{\text {av. }}, \mathrm{MJ} / \mathrm{m}^{2}$ & $12.7 \pm 3.4$ & $22.4 \pm 0.7$ & $24.2 \pm 1.7$ \\
\hline TSR $_{\text {av. }}, \mathrm{m}^{2} / \mathrm{m}^{2}$ & $398 \pm 65$ & $801 \pm 62$ & $951 \pm 69$ \\
\hline $\mathrm{COY}_{\text {av. }}, \mathrm{kg} / \mathrm{kg}$ & $0.15 \pm 0.03$ & $0.14 \pm 0.01$ & $0.13 \pm 0.01$ \\
\hline $\mathrm{CO}_{2} \mathrm{Y}_{\text {av. }}, \mathrm{kg} / \mathrm{kg}$ & $4.4 \pm 0.5$ & $3.4 \pm 0.1$ & $3.1 \pm 0.2$ \\
\hline
\end{tabular}

\section{General conclusions}

1. The dependence of apparent density on the amount of water may be approximated by the regression equation allowing prediction of average values of apparent density when the amount of water ranges from 1.0 pbw to 6.0 pbw. The obtained products are characterised by the apparent density ranging from $25.2 \mathrm{~kg} / \mathrm{m}^{3}$ to $124 \mathrm{~kg} / \mathrm{m}^{3}$, initial shrinkage and dimensional stability at $70^{\circ} \mathrm{C}$ temperature and $90 \%$ relative humidity conditions of $(0.3 \leq \mathrm{MS} \leq 9) \%$ for length and width and $(0.5 \leq \mathrm{MS} \leq 16) \%$ for thickness.

2. Dimensionally stable polyurethane foams are obtained when from 10 pbw to $20 \mathrm{pbw}$ of propylene glycol from rapeseed glycerine is used. It determines products which are characterised by initial shrinkage and dimensional stability at $70^{\circ} \mathrm{C}$ temperature and $90 \%$ relative humidity conditions varying of $0.8 \%$ for length and width and from $0.2 \%$ to $1 \%$ for thickness. The apparent density of such products is in the range of $40.7-42.1 \mathrm{~kg} / \mathrm{m}^{3}$, and compressive strength varies from $185 \mathrm{kPa}$ to $197 \mathrm{kPa}$.

3. Titanate coupling agent forms one molecule-sized layer on the surface of PPWS particles, thus reducing dynamic viscosity of the forming mixtures almost 2.3 times at the maximum amount, i. e. $20 \mathrm{wt}$ \% of PPWS particles.

4. PPWS particles form partially closed cell structure which is characterised by smaller cells, and determine physical as well as mechanical properties of polyurethane foam from rapeseed oil based polyols. It is obtained dimensionally stable polyurethane foam with the density in the range of $40-50 \mathrm{~kg} / \mathrm{m}^{3}$, compressive strength ranging from $193 \mathrm{kPa}$ to $243 \mathrm{kPa}$, thermal conductivity - from $0.0349 \mathrm{~W} /(\mathrm{m} \cdot \mathrm{K})$ to $0.0359 \mathrm{~W} /(\mathrm{m} \cdot \mathrm{K})$, long-term water absorption by total immersion - from 6 vol. $\%$ to 11 vol. \% and water vapour diffusion resistance factor - from 26.2 to 40.9 .

5. PPWS particles and their agglomerates due to non-flammable materials $\left(\mathrm{H}_{2} \mathrm{O}\right.$ and $\mathrm{CO}_{2}$ ) act as a barrier for flame spread and sudden heat release in modified polyurethane foams under open flame, therefore, the obtained products are 
characterised by slower combustion. 20 wt. \% of PPWS particles in polyurethane foam averagely reduce heat release rate by $5.1 \%$, carbon monoxide and carbon dioxide yields by, respectively, $13.3 \%$ and $29.5 \%$.

\section{Recommendations}

1. In order to prepare a mixture of component A for the production of sprayed thermal insulating layer, layer for sandwitch panels, slabs with diffusion tight coating or witout it, the recommended ratios of components $\mathrm{A}$ and $\mathrm{B}$ are:

- when polyols mixture contains 10 pbw of RPG and 5 wt. \%, 10 wt. \%, 15 wt. \% and 20 wt. \% of PPWS particles, respectively (1:1.4), (1:1.2), (1:1.1) and (1:1);

- when polyols mixture contains 15 pbw of RPG and 5 wt. \%, 10 wt. \%, 15 wt. \% and 20 wt. \% of PPWS particles, respectively (1:1.6), (1:1.3), (1:1.2) ir (1:1.05);

- when polyols mixture contains 20 pbw of RPG and 5 wt. \%, 10 wt. \%, 15 wt. \% and 20 wt. $\%$ of PPWS particles, respectively (1:1.7), (1:1.5), (1:1.3) ir (1:1.1).

2. Based on properties stability, the appropriate amounts of RPG and PPWS particles for the production of thermal insulating layer and its application as thermal insulating material in building envelopes are as follows:

- from 5 wt. \% to 10 wt. \% of PPWS particles and from 10 pbw to 20 pbw of RPG for the production of sprayed thermal insulation;

- from 5 wt. \% to 20 wt. \% of PPWS particles and 15 pbw of RPG for rigid polyurethane foam slabs with diffusion tight coating and milled edges as well as for production of sandwith panels;

- from 5 wt. \% to 20 wt. \% of PPWS particles and from 15 pbw to 20 pbw of RPG for the production of rigid diffusion tigh coating free polyurethane foam slabs with milled edges. 
Priedai $^{4}$

A priedas. Skirtingu literatūros šaltiniu pateikiamos cheminès popieriaus gamybos atliekų dumblo sudètys

B priedas. Grandinès plètikliais modifikuotu poliuretano putų struktūriniai parametrai

C priedas. Propilenglikoliu ir popieriaus gamybos atliekų dumblo dalelėmis modifikuotų poliuretano putų vidutinès šilumos laidumo koeficiento vertès

D priedas. Disertacijos autorès sąžiningumo deklaracija

E priedas. Bendraautoriu sutikimai teikti publikacijose skelbtą medžiagą daktaro disertacijoje

F priedas. Autorès mokslinių publikacijų disertacijos tema kopijos

${ }^{4}$ Priedai pateikiami pridètoje kompaktinèje plokštelèje 


\section{Agnè KAIRYTÉ}

BIOPOLIURETANO PUTỤ, MODIFIKUOTỤ POPIERIAUS

GAMYBOS ATLIEKOMIS, TYRIMAI

Daktaro disertacija

Technologijos mokslai,

medžiagų inžinerija (08T)

RESEARCH OF BIOPOLYURETHANE FOAM MODIFIED WITH PAPER PRODUCTION WASTE

Doctoral Dissertation

Technological Sciences, Materials Engineering (08T)

$20171002.12,75$ sp. I. Tiražas 20 egz.

Vilniaus Gedimino technikos universiteto

leidykla „Technika“,

Saulètekio al. 11, 10223 Vilnius,

http://leidykla.vgtu.lt

Spausdino Bl UAB „Baltijos kopija“

Kareivių g. 13B, 09109 Vilnius 